UNIVERSIDADE DE SÃO PAULO

FACULDADE DE FILOSOFIA, LETRAS E CIÊNCIAS HUMANAS DEPARTAMENTO DE CIÊNCIA POLÍTICA

\author{
FÁBIO LACERDA
}

\title{
Pentecostalismo, Eleições e Representação Política no Brasil Contemporâneo
}

VERSÃO CORRIGIDA

São Paulo 
FÁBIO LACERDA

\section{Pentecostalismo, Eleições e Representação Política no Brasil Contemporâneo}

Tese apresentada ao Programa de Pós-graduação do Departamento de Ciência Política da Universidade de São Paulo como requisito parcial para a obtenção do título de Doutor em Ciência Política.

Em acordo com a versão corrigida. Orientador: Prof. Dr. Paolo Ricci

VERSÃO CORRIGIDA

São Paulo 
Autorizo a reprodução e divulgação total ou parcial deste trabalho, por qualquer meio convencional ou eletrônico, para fins de estudo e pesquisa, desde que citada a fonte.

Catalogação na Publicação

Serviço de Biblioteca e Documentação

Faculdade de Filosofia, Letras e Ciências Humanas da Universidade de São Paulo

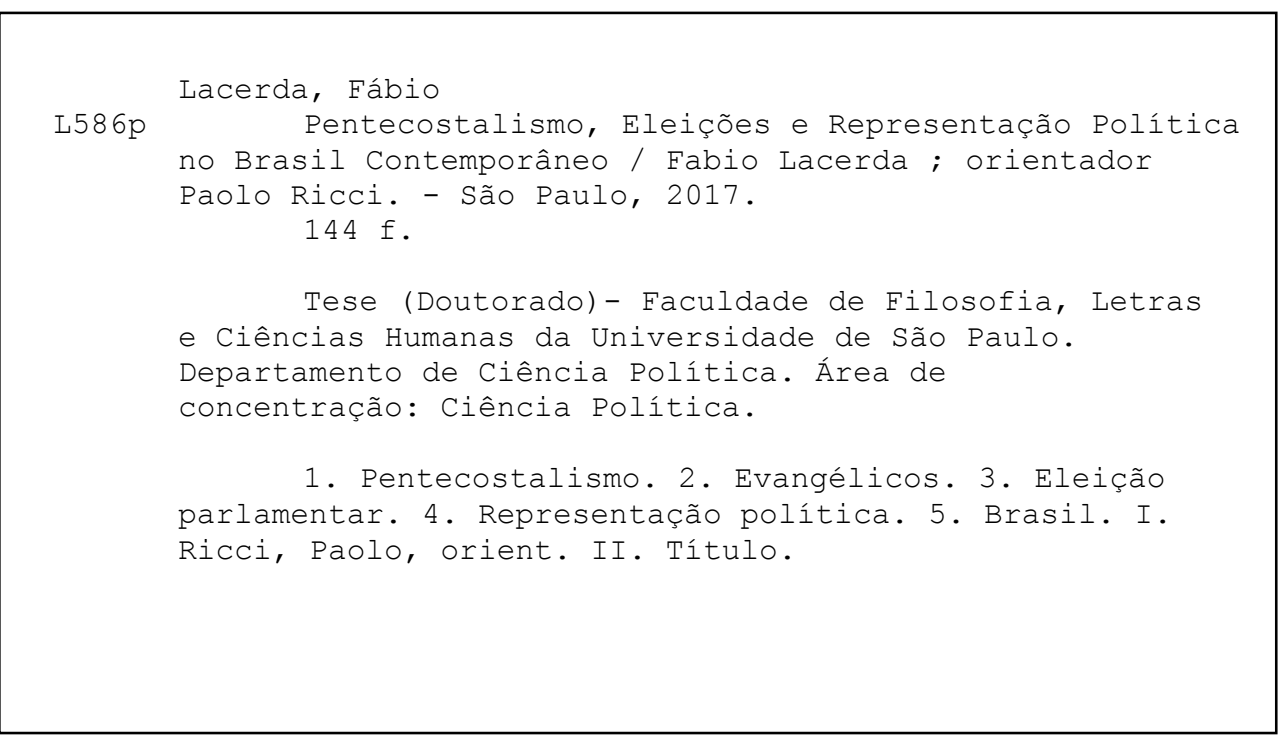




\section{LACERDA, F. Pentecostalismo, Eleições e Representação Política no Brasil}

Contemporâneo. Tese apresentada à Faculdade de Filosofia, Letras e Ciências Humanas da Universidade de São Paulo para obtenção do título de Doutor em Ciência Política. 2017.

Aprovado em:

Banca Examinadora

Prof. Dr.

Instituição:

Julgamento:

Assinatura:

Prof. Dr. Instituição:

Julgamento: Assinatura:

Prof. Dr. Instituição:

Julgamento: Assinatura:

Prof. Dr. Instituição:

Julgamento: Assinatura:

Prof. Dr. Instituição:

Julgamento: Assinatura: 
Para meus pais, sempre.

Para Lilian, meu amor. 


\section{Agradecimentos}

Estes agradecimentos são uma tentativa modesta e imperfeita de reconhecer a importância que muitas pessoas tiveram na realização deste trabalho. Muitos mais deveriam ser citados e não o serão. Para os citados, as citações certamente não farão jus à importância que tiveram.

Em primeiro lugar, expresso minha profunda gratidão a meu orientador, Paolo Ricci, que, com paciência e atenção, acompanhou-me desde o início do mestrado até aqui. Agradeço aos integrantes da banca de qualificação, professores Amâncio Oliveira e Lorena Barberia, pelas sugestões e observações. Agradeço aos professores do Departamento de Ciência Política (DCP) da USP, de modo particular aos já citados, mas também a Fernando Limongi, Adrián Lavalle e Glauco Peres, pela inspiração, dedicação e exemplo acadêmico. Registro, por fim, um agradecimento especial ao professor Rogério Arantes, a quem tive o privilégio de ter como coordenador da Pós-graduação durante a maior parte de meu período de mestrado e doutorado.

Agradeço à Coordenação de Aperfeiçoamento de Pessoal de nível Superior (CAPES) pelo apoio financeiro no primeiro ano desta pesquisa. Agradeço ao Programa de Pós-graduação do DCP, em particular a Vasne, Leonardo, Márcia e Maria Raimunda, por toda a ajuda prestada. Agradeço aos amigos do DCP, dentre os quais cito Lucas Petroni, Marcos Lucca-Silveira, Rafael Nunes Magalhães, a todos os colegas do Seminário de Tese e a todos os demais amigos e amigas que não serão aqui citados. Agradeço, também, ao colega e amigo Miguel Barrientos, pela amizade eterna.

Devo um agradecimento a Rodolpho Bernabel, Tiago Borges, Alejandro Avenburg, Guadalupe Tuñon, George Avelino e Cláudia Cerqueira, pela leitura e comentários a versões anteriores de capítulos desta tese. Agradeço a Taylor Boas por comentários às minhas ideias de pesquisa. Agradeço a Ricardo Mariano pelo diálogo fraterno e pela disposição de ter lido e comentado versões anteriores dos dois primeiros capítulos. Devo um agradecimento muito especial ao amigo Sergio Simoni Jr., com quem discuti quase todos os capítulos da tese, e a quem são devidos muitos méritos deste trabalho. Agradeço a Carlos Martins, meu pai, pela revisão do texto e pela ajuda na coleta de informações. Por fim, agradeço a Pedro Paulo Vargas, Diego Klautau, Carla Araújo, Renato Ladeia, Marco Aurélio Vallim, Patrícia P. Adachi, Wilson Pires e Laura MacLennan pela valiosa ajuda na aplicação dos questionários.

Agradeço a todos os pastores e representantes de igrejas evangélicas que contribuíram com seu tempo para a elaboração deste trabalho. Faço uma menção especial às assessoras do vereador Carlos Evaristo e do deputado Jefferson Campos, ambos da Igreja do Evangelho Quadrangular, pela atenção e ajuda com as informações. 
Não poderia deixar de agradecer ao Centro Universitário da Fundação Educacional Inaciana (FEI) «Pe. Saboia de Medeiros», onde, desde 2014, tenho o privilégio de lecionar. Agradeço, em especial, à Carla Araújo, chefe do Departamento de Ciências Sociais e Jurídicas, e a todos os amigos docentes, por me oferecerem um ambiente tão rico e fraterno.

Posso me orgulhar de ter amizades duradouras e de valor incalculável. Por isso, faço um agradecimento a Felipe Sabino, Marcos Fonseca, Guilherme Zwetsch e todos os amigos da Escola Nossa Senhora das Graças (Gracinha). Devo, também, um agradecimento profundo aos amigos do Centro de Estudos Universitários do Sumaré, e, em especial, a Henrique Elfes, Leonardo Soriano, Hugo Sakamoto e Guilherme Melo.

Por fim, devo um agradecimento especial à Lilian Ferreira, minha noiva, pelo amor, exemplo e inspiração. Agradeço, também, à minha família, em especial à Fátima Araújo e a minhas tias Eli, Beth, Ciça, Eliane e Elieth. Finalmente, minha gratidão profunda se deve a meus pais, Eloisa e Carlos, que foram sempre em minha vida um sinal de Graça não merecida. A todas essas pessoas são devidos os méritos deste trabalho. Se houver equívocos, eles são de minha responsabilidade. 
The widely held idea, codified in the theory of secularization, that modernizing societies will become progressively irreligious is vulnerable to powerful objections, as is the prediction, also associated with the theory of secularization, that modern citizens will engage in their religious practices 'pianissimo', in ever more privatized a fashion. Religion - and, specifically, public religion seems here to stay.

Christopher Eberle ${ }^{1}$

\footnotetext{
${ }^{1}$ Religious Convictions in Liberal Politics. Cambridge University Press, 2002, p. 6.
} 


\section{RESUMO}

\section{LACERDA, F. Pentecostalismo, Eleições e Representação Política no Brasil}

Contemporâneo. Tese (Doutorado). Faculdade de Filosofia, Letras e Ciências Humanas, Universidade de São Paulo, 2017.

Esta tese investiga a recente mobilização política dos evangélicos no Brasil. Seu objetivo é analisar certas suposições encontradas na literatura sobre o crescimento evangélico (sobretudo pentecostal) e seu impacto político na América Latina e, em particular, no Brasil. Essas suposições dizem respeito à relação estabelecida entre político evangélico e eleitor; ao crescimento da presença evangélica nos legislativos brasileiros; à «força» eleitoral dos candidatos evangélicos e das igrejas pentecostais; e ao apoio de eleitores evangélicos a candidatos que sinalizam a mesma religião. Para realizar esse objetivo, a tese se apoia em revisão da literatura relevante, na construção de um novo banco de dados de candidaturas evangélicas para o legislativo no Brasil (1998-2014) e na realização de um experimento de survey com estudantes universitários da cidade de São Paulo. Os dados são analisados por meio de estatística descritiva, modelos de regressão OLS e logística. Os resultados revelam um quadro mais complexo sobre a atuação política evangélica do que a literatura costuma supor. As afirmações sobre a suposta atuação clientelista dos deputados evangélicos, conquanto não necessariamente equivocadas, não encontram apoio na produção de leis do estado de São Paulo. Entre 1998 e 2014, o número de candidaturas evangélicas para a Câmara dos Deputados e para as Assembleias Legislativas aumentou em termos absolutos, mas se manteve estável em termos relativos. O número de evangélicos eleitos aumentou no período, mas permanece inferior à proporção de evangélicos na população brasileira. Os deputados evangélicos são, cada vez mais, provenientes de igrejas pentecostais que adotam o modelo de representação corporativa. $O$ apoio dessas igrejas a seus «candidatos oficiais» produz um efeito positivo sobre seu desempenho eleitoral mesmo controlando por fatores como gasto de campanha, incumbência, partido, entre outros. Porém, a despeito das suposições de apoio irrestrito dos fiéis a candidatos de suas igrejas, o sucesso eleitoral das igrejas pentecostais é menor do que se assevera. Por fim, o uso de pistas religiosas por parte de candidatos evangélicos só tem efeito positivo sobre os eleitores evangélicos condicionado ao tamanho da oferta de candidatos. Por outro lado, tem efeito negativo sobre outros grupos religiosos, sobretudo num cenário com apenas dois candidatos.

Palavras-chave: Evangélicos; pentecostais; candidatos; eleições; legislativo. 


\begin{abstract}
LACERDA, F. Pentecostalism, Elections and Political Representation in Contemporary

Brazil. Tese (Doutorado). Faculdade de Filosofia, Letras e Ciências Humanas, Universidade de São Paulo, 2017.

This thesis investigates the recent political-electoral mobilization of Evangelicals in Brazil. Its aim is to analyze certain assumptions found in the literature on Evangelical (and specially Pentecostal) growth and its political impact in Brazil and Latin America. These assumptions concern the relationship established between Evangelical politicians and voters; the growth of Evangelical presence in Brazilian legislatures; the electoral «force» of Evangelical candidates and Pentecostal churches; and the support of Evangelical voters to candidates who signal the same religion. In order to achieve this objective, the thesis is based on a review of the relevant literature, the construction of a new database of Evangelical candidacies for the Brazilian legislatures (1998-2014) and the conducting of a survey experiment with undergraduate students from the city of São Paulo. The data are analyzed through descriptive statistics, OLS regression models and logistic regression models. The results reveal a more complex picture of Evangelical political activity than the literature usually presumes. The statements about the supposed clientelistic performance of Evangelical legislators, if not necessarily mistaken, do not find support in the law making of the state of São Paulo. Between 1998 and 2014, the number of Evangelical candidates to the Chamber of Deputies and to the Legislative Assemblies increased in absolute terms, but remained relatively stable. The number of elected Evangelicals has increased in the period, but remains below the proportion of Evangelicals in the Brazilian population. Evangelical deputies are increasingly coming from Pentecostal churches that adopt the model of corporate representation. The support of these churches to their "official candidates" has a positive effect on their electoral performance even if controlling for factors such as campaign spending, incumbency, party, among others. However, despite assumptions of unrestricted support from the faithful to candidates from their churches, the electoral success of Pentecostal churches is lesser than what is asserted. Finally, the use of religious cues by Evangelical candidates only has a positive effect on Evangelical voters conditioned by the size of the candidates' offer. On the other hand, it has a negative effect on other religious groups, especially in a scenario with only two candidates.
\end{abstract}

Keywords: Evangelicals; Pentecostals; candidates; Brazilian elections; legislative. 


\section{Sumário}

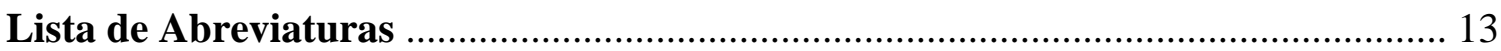

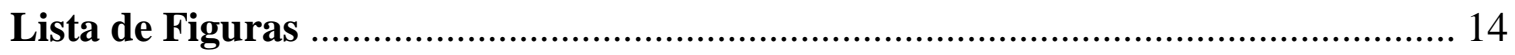

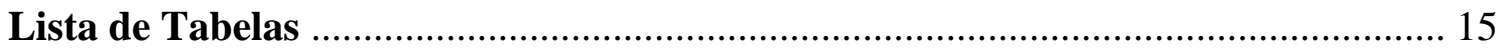

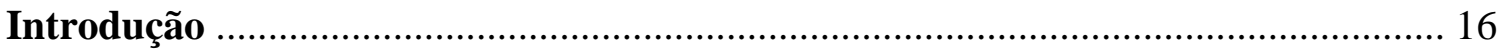

1. Pentecostalismo e Política: uma Avaliação da Literatura Sobre América Latina e

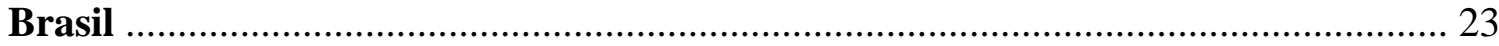

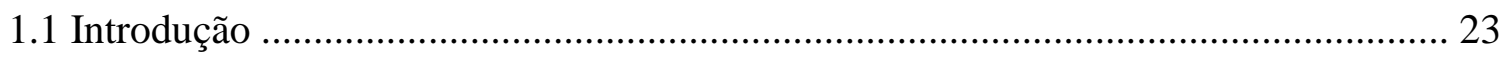

1.2 As transformações religiosas na América Latina e no Brasil ...................................... 24

1.3 Crescimento pentecostal e política na América Latina ................................................ 27

1.4 Crescimento pentecostal e política no Brasil ............................................................... 36

1.5 Seriam os projetos de lei dos deputados pentecostais paroquiais? ........................... 48

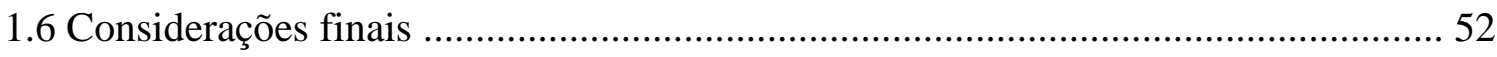

2 Evangélicos, Pentecostais e Representação Política nas Eleições para o Legislativo

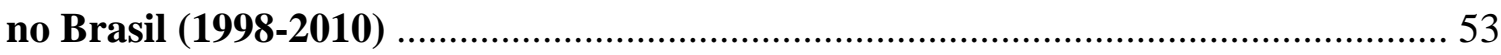

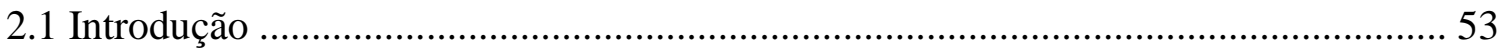

2.2 Candidatos evangélicos e pentecostais: discussão conceitual e metodológica ........... 55

2.3 Um quadro geral das candidaturas evangélicas para o legislativo ............................. 67

2.4 Comparando candidatos evangélicos e «candidatos oficiais» pentecostais ............. 74

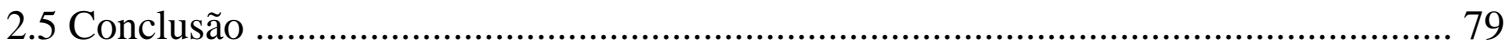

3 Estimando o Efeito de Ser Candidato Pentecostal sobre o Voto nas Eleições

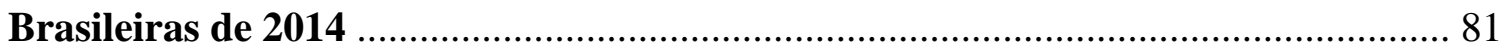

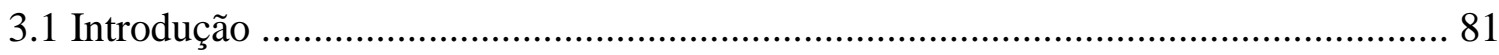

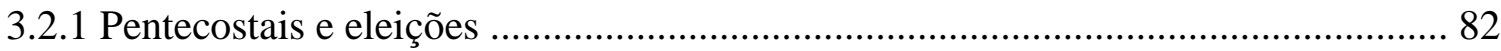

3.2.2 Explicando o desempenho nas eleições para o legislativo ....................................... 86

3.3 Teoria e hipóteses: pentecostais, igrejas e gasto de campanha ................................... 89

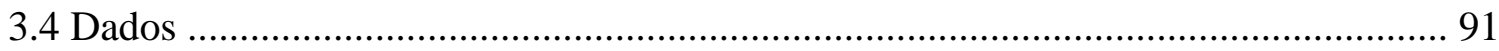

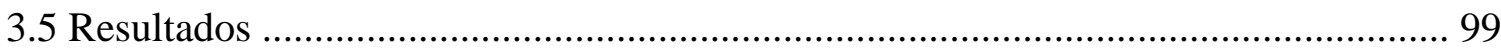

3.6 Evidências qualitativas .................................................................................... 103 


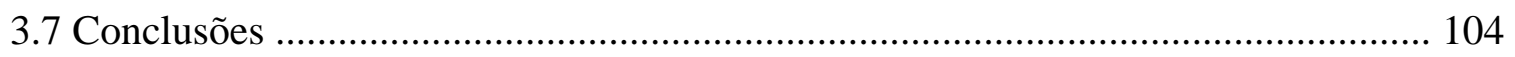

4 Pistas Religiosas, Oferta de Candidatos e Escolha Eleitoral para o Legislativo no

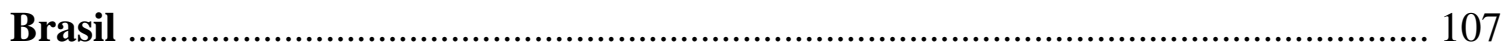

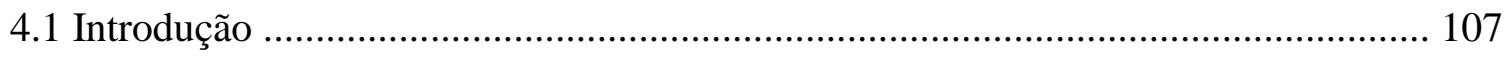

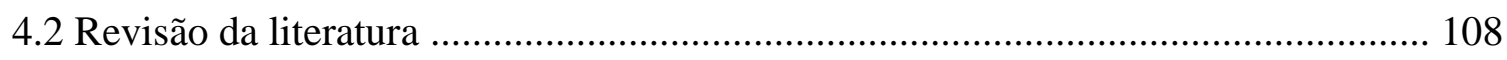

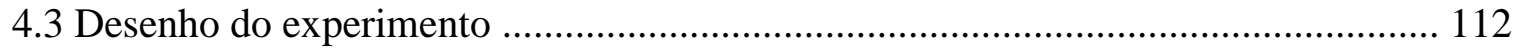

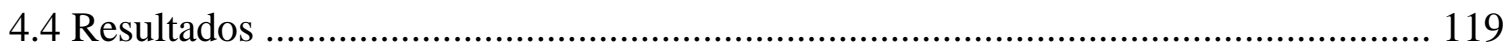

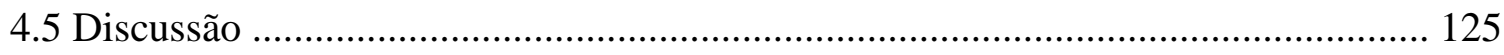

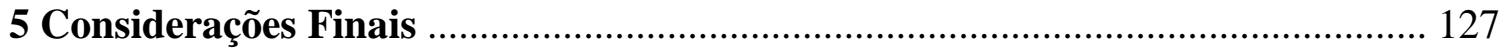

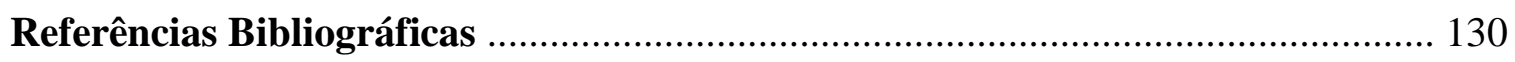

Apêndice A: Modelos OLS para Câmara e Assembleias ................................... 139

Apêndice B: Regressões logísticas para voto no candidato Felipe Souza .............. 141

Apêndice C: Questionário do experimento .................................................... 142 


\section{Lista de Abreviaturas}

$\begin{array}{ll}\text { AD } & \text { Assembleia de Deus } \\ \text { CGADB } & \text { Convenção Geral das Assembleias de Deus no Brasil } \\ \text { CNBB } & \text { Conferência Nacional dos Bispos do Brasil } \\ \text { CONAMAD } & \text { Convenção Nacional das Assembleias de Deus no Brasil } \\ \text { DEM } & \text { Democratas } \\ \text { IEQ } & \text { Igreja do Evangelho Quadrangular } \\ \text { IIGD } & \text { Igreja Internacional da Graça de Deus } \\ \text { IMPD } & \text { Igreja Mundial do Poder de Deus } \\ \text { IURD } & \text { Igreja Universal do Reino de Deus } \\ \text { PDT } & \text { Partido Democrático Trabalhista } \\ \text { PFL } & \text { Partido da Frente Liberal } \\ \text { PL } & \text { Partido Liberal } \\ \text { PMDB } & \text { Partido do Movimento Democrático Brasileiro } \\ \text { PPB } & \text { Partido Progressista Brasileiro } \\ \text { PP } & \text { Partido Progressista } \\ \text { PRB } & \text { Partido Republicano Brasileiro } \\ \text { PRONA } & \text { Partido da Reedificação da Ordem Nacional } \\ \text { PSB } & \text { Partido Socialista Brasileiro } \\ \text { PSC } & \text { Partido Social Cristão } \\ \text { PSD } & \text { Partido Social Democrático } \\ \text { PSDB } & \text { Partido da Social Democracia Brasileira } \\ \text { PSL } & \text { Partido Social Liberal } \\ \text { PSOL } & \text { Partido Socialismo e Liberdade } \\ \text { PT } & \text { Partido dos Trabalhadores } \\ \text { TSE } & \text { Tribunal Superior Eleitoral } \\ & \end{array}$




\section{Lista de Figuras}

FIGURA 1. Percentual da população católica e protestante no Brasil ........................... 26

FIGURA 2. Número de deputados federais evangélicos eleitos (1946-1991) ................. 37

FIGURA 3. Tamanho das igrejas pentecostais em relação ao total de evangélicos ........ 61

FIGURA 4. Número de candidatos evangélicos sem igreja identificada ....................... 65

FIGURA 5. Votações de candidatos evangélicos sem igreja identificada ....................... 66

FIGURA 6. Candidatos evangélicos para a Câmara e Assembleias ............................... 67

FIGURA 7. Candidatos evangélicos eleitos para a Câmara e Assembleias .................... 69

FIGURA 8. Candidatos evangélicos por estado (total e eleitos) .................................. 71

FIGURA 9. Candidatos evangélicos (total e eleitos) por partido político ...................... 73

FIGURA 10. Número de pentecostais corporativos e evangélicos eleitos ..................... 75

FIGURA 11. Número de candidatos (total e eleitos) por igreja pentecostal .................. 78

FIGURA 12. Votação dos candidatos evangélicos .................................................... 85

FIGURA 13. Efeito de ser pentecostal sobre o gasto ............................................ 100

FIGURA 14. Efeito de ser evangélico ou pentecostal sobre o voto ............................. 100

FIGURA 15. Efeito de ser apoiado pela IURD sobre o voto ........................................ 101

FIGURA 16. Candidatos apresentados aos respondentes ....................................... 117

FIGURA 17. Aleatorização e balanço de variáveis entre grupos de tratamento ........... 120 


\section{Lista de Tabelas}

Tabela 1. Percentual da população católica e protestante no Brasil .............................. 49

Tabela 2. Efeito de ser pentecostal sobre projeto de lei paroquial ................................. 50

Tabela 3. Tipos de relação entre candidato e igreja ...................................................... 58

Tabela 4. Títulos evangélicos dos candidatos para a Câmara e Assembleias (\%) ........... 63

Tabela 5. Relação gasto/voto (em R\$) nas eleições de 2014 ........................................ 90

Tabela 6. Número total de candidatos, evangélicos e pentecostais ............................... 93

Tabela 7. Amostra contendo apenas candidatos com $\geq 0.02 \%$ de votos ..................... 93

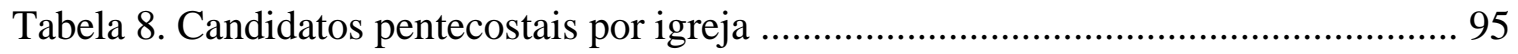

Tabela 9. Candidatos pentecostais por partido ..................................................... 98

Tabela 10. Descrição da amostra .......................................................................... 113

Tabela 11. Religião da amostra (em \%) ................................................................ 115

Tabela 12. Religião e frequência ao culto (em \%) ....................................................... 115

Tabela 13. Amostra segundo condições de tratamento ............................................. 119

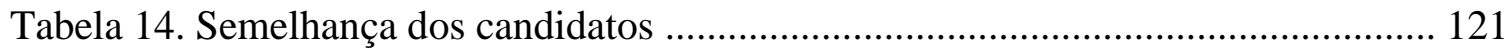

Tabela 15. Proporção de respondentes que escolheram Felipe Souza ......................... 122

Tabela 16. Regressões logísticas para voto no candidato Felipe Souza ...................... 124 


\section{Introdução}

No dia 30 de outubro de 2016, o senador do PRB e bispo licenciado da Igreja Universal do Reino de Deus, Marcelo Crivella, foi eleito prefeito do Rio de Janeiro. Crivella disputou o segundo turno contra Marcelo Freixo (PSOL) e ganhou com folgada vantagem. Em seu primeiro discurso após a vitória, o candidato eleito disse ter vencido uma «enorme onda de preconceito» ${ }^{2}$. Ao menos num sentido descritivo, ele estava certo. Fundadas ou não, muitas suspeitas foram levantadas pela opinião pública sobre a idoneidade moral da Igreja Universal, sobre as relações que o candidato mantinha com a Igreja, e, mais importante, sobre como tais relações influenciariam seu governo.

A eleição de Crivella foi obviamente eficaz para tornar ainda mais central no debate público brasileiro a discussão sobre a adequação (ou não) da participação religiosa na política. Porém, a conturbada história política do país vivida entre 2014 e 2016 fez com que, embora importante, a eleição de Crivella não tenha sido, nem de longe, o único episódio relevante nesse sentido. No dia 17 de abril de 2016, a Câmara dos Deputados votou e aprovou a admissibilidade do processo de impeachment contra a presidente Dilma Rousseff. A votação se transformou num verdadeiro espetáculo midiático. Em pouco tempo, a atuação dos deputados se tornou alvo de fortes críticas. A ministra da Agricultura Katia Abreu (PMDB-TO), por exemplo, referiu-se a ela como um «show de horrores» ${ }^{3}$. O ex-presidente do STF, Joaquim Barbosa, classificou o episódio como «patético» e uma «vergonha». Mas, além das críticas feitas por distintos representantes da elite política, as críticas também se disseminaram entre boa parte da população.

A atuação dos deputados brasileiros na votação do impeachment foi alvo de críticas por diversas razões, mas três, em especial, se destacaram. A primeira foi o suposto paroquialismo dos deputados, que, na hora de anunciar seus votos, teriam colocado seus interesses particulares na frente dos interesses do país (além de fazerem pouca ou nenhuma referência aos aspectos técnicos do processo). A segunda foi o suposto baixo nível educacional dos deputados. Foi, de fato, a primeira vez que muitos brasileiros tiveram uma imagem mais clara de quem ocupava o Congresso. Por fim, a terceira foi o discurso recheado de referências religiosas feito por muitos deputados. As menções a «Deus» e à «família» levaram muitos a afirmar que a laicidade do Estado estaria em perigo.

\footnotetext{
${ }^{2}$ «Marcelo Crivella é eleito prefeito do Rio e diz que venceu 'onda de preconceito'». G1, 30/10/16.

3 «Kátia Abreu diz que sessão do impeachment foi "show de horrores"». Estadão, 20/04/16.

4 «"É de chorar de vergonha! Simplesmente patético", diz Joaquim Barbosa sobre votação do impeachment». Estadão, 19/04/16.
} 
Porém, o voto e o discurso de deputados religiosos a favor do impeachment foram apenas a consequência de um processo iniciado muito antes, e para o qual mais uma vez foi importante a influência de políticos evangélicos. Desde a vitória de Luiz Inácio Lula da Silva, em 2002, os governos liderados pelo Partido dos Trabalhadores (PT) ganharam apoio considerável de lideranças evangélicas nacionais, mesmo o partido não sendo, para muitas delas, a primeira e melhor opção. O «casamento» entre evangélicos e o PT começou com Lula e durou até o impeachment de Dilma ${ }^{5}$. Não foi sempre, é verdade, uma lua-de-mel. A despeito do apoio, ações do governo petista tais como o Terceiro Programa Nacional de Direitos Humanos (PNDH-3), que defendia a descriminalização do aborto e o casamento homossexual, causaram óbvio desconforto na elite política evangélica (cf. Machado, 2012). Ainda assim, foi apenas com a perspectiva da crise e eventual colapso do governo Dilma que lideranças evangélicas retiraram seu apoio ao PT. Em fevereiro de 2012, o senador e bispo licenciado Marcelo Crivella era escolhido pelo Planalto para assumir o Ministério da Pesca ${ }^{6}$. Em março de 2016, o líder da Universal, Edir Macedo, decretava o fim do apoio de sua igreja (e, por extensão, do PRB) ao governo de Dilma Rousseff ${ }^{7}$.

Mas a conturbada história política brasileira do período 2014-2016 foi palco de ainda outro episódio que, mais uma vez, colocou de algum modo os evangélicos no centro do debate público. Dessa vez, refiro-me ao protagonismo de Eduardo Cunha (PMDB-RJ) no impeachment da presidente Dilma Rousseff. Em que pesem as diferentes interpretações acerca do fato, todas reconhecem a importância que Cunha nele desempenhou. Desde os equívocos do PT em sua aliança com o PMDB do estado do Rio de Janeiro, passando pela tentativa petista de «desidratar» o PMDB por meio da criação de novos partidos (vide PSD), até a derrota do governo na eleição para a Presidência da Câmara - Cunha foi eleito com 267 votos, contra 136 de Arlindo Chinaglia (PT-SP) -, todos esses fatos contribuíram para o sucesso de Cunha, cuja ascensão, não por coincidência, foi concomitante à diminuição do apoio dado pela bancada do PMDB ao governo (cf. Limongi, 2015).

A ascensão de Eduardo Cunha à Presidência da Câmara, assim como sua influência sobre um grande número de deputados que, segundo relatos da mídia, constituiriam sua «bancada particular», foram de extrema importância para o impeachment ${ }^{8}$. Se tal protagonismo, por si só, já seria suficiente para transformar Cunha numa espécie de «encarnação do mal» para a esquerda brasileira, o fato de o deputado fluminense ser também evangélico pentecostal, posicionando-se contra a legalização do aborto e o casamento homossexual, despertou mais uma vez na opinião

\footnotetext{
5 «Como os evangélicos abençoaram Temer». Revista Época, 11/05/16.

6 «Senador Marcelo Crivella, da Igreja Universal, é escolhido para ser novo ministro do governo Dilma». Gospel+, 29/02/12.

${ }_{8}$ «Com apoio de bispo, Igreja Universal rompe com Dilma». UOL, 18/03/16.

8 «Cotado para presidir a Câmara, Cunha se mantém com bancada particular». Folha de S. Paulo, 23/11/14.
} 
pública um sentimento de hostilidade ao que entendia ser um ativismo evangélico ilegítimo na política.

Mais uma vez, o reconhecimento de que lideranças evangélicas contribuíram e eventualmente atuaram de forma direta para a débâcle do governo Dilma não deve perder de vista que, tanto em seu primeiro governo, como nos dois governos Lula, lideranças evangélicas foram cortejadas e aceitaram apoiar esses governos. Cunha, o mesmo que em 2016 teve protagonismo fundamental no impeachment de Dilma, em 2010 defendia em templos evangélicos a candidatura da petista, afirmando aos fiéis serem infundados os «boatos plantados pelos adversários» de que ela fosse a favor do aborto ${ }^{9}$.

Todos os fatos até aqui mencionados - eleição de um bispo da Universal para a Prefeitura do Rio; discursos religiosos na mais midiática votação da Câmara dos Deputados; relações de apoio mútuo entre líderes evangélicos e políticos; protagonismo de um deputado evangélico no processo de impedimento da Presidente - têm pelo menos uma característica em comum: todos levaram para o centro do debate público brasileiro a discussão sobre a mobilização política de grupos religiosos, e, em especial, dos evangélicos. Cada um desses episódios gerou questionamentos públicos sobre até que ponto tal mobilização estaria de acordo com um sistema laico e democrático. Os episódios que narrei não são, obviamente, os únicos. A história brasileira pós-redemocratização não pode ser desvinculada do impressionante crescimento da população evangélica no período, só comparável ao declínio do número de católicos. Esse crescimento teve consequências políticas: se, até a década de 1970, prevalecia entre os evangélicos a tese do afastamento da política, a partir da década de 1980 diferentes igrejas decidiam participar ativamente das disputas eleitoral e partidária. As eleições de 1986 levaram ao Congresso Constituinte um número recorde de representantes evangélicos, e, desde então, ainda que com oscilações, o número de evangélicos na Câmara dos Deputados vem crescendo.

É forçoso reconhecer que, ao contrário do que parece crer certa militância laicista, a presença da religião na política brasileira sempre foi, desde a proclamação da República em 1889 até hoje, muito mais a regra do que a exceção. Se, oficialmente, a proclamação levou à separação entre Igreja Católica e Estado, boa parte do establishment político brasileiro aceitou durante a primeira metade do século XX o catolicismo como religião oficial de fato (cf. Della Cava, 1976). Entre os que se opunham a tal estado de coisas estavam, justamente, os protestantes ${ }^{10}$. Se, no início do século XX, católicos tentaram influenciar a política por meio da ação do cardeal d. Sebastião Leme, e, depois, pela ação de leigos via Ação Católica, Liga Eleitoral Católica, Centro Dom Vital e outros grupos, a partir da década de 1950 tal influência se daria também pela

\footnotetext{
9 «Eduardo Cunha vai a templos defender Dilma contra boatos». Folha de S. Paulo, 11/10/10.

10 Ao longo deste trabalho, por uma questão de estilo, optei por usar os termos «protestante» e «evangélico» sem distinção de sentido, ainda que reconheça que os termos não são equivalentes em sentido estrito.
} 
criação da Conferência Nacional dos Bispos do Brasil (CNBB), cuja atuação política durante o regime militar se tornou conhecida. Nesse sentido, talvez seja correto dizer que, se há uma especificidade na recente mobilização política de grupos religiosos, é o fato de que os protagonistas são, agora, os evangélicos.

O apoio e participação de igrejas evangélicas pentecostais nas eleições das últimas décadas tem sido alvo de críticas por parte da mídia e da academia. Uma interpretação comum desse fenômeno é aquela que, embora enxergue as igrejas pentecostais como forças conservadoras e nocivas, acredita que seu apoio seria imprescindível para um partido ganhar uma eleição e, eventualmente, governar. Tratar-se-ia de um «mal necessário». Numa leitura que se origina, talvez, na obra de d'Epinay (1970), líderes evangélicos locais atuariam como «coronéis», controlando «rebanhos eleitorais» que seguiriam a orientação política dos seus pastores. Esses líderes ofereceriam o apoio eleitoral de seus rebanhos a políticos, que, em troca, beneficiariam as igrejas. Ainda na mesma chave, os próprios pastores se candidatariam a cargos legislativos com o apoio de suas congregações, e, uma vez eleitos, produziriam políticas para benefício de suas igrejas e contrárias ao bem público. Dado o extraordinário crescimento evangélico no Brasil recente; dado que, em 2010, mais de um quinto dos brasileiros eram evangélicos; dada tal realidade, o apoio de líderes evangélicos se tornaria necessário a qualquer candidato que almejasse o sucesso eleitoral ${ }^{11}$.

A literatura acadêmica que se debruçou sobre a relação entre evangélicos e política na América Latina questionou a adequação da mobilização política evangélica a um sistema democrático. A partir de uma leitura das teorias da modernização, e, em particular, de um de seus principais componentes, a secularização, a expansão das igrejas evangélicas e sua incursão na política eleitoral e partidária seria vista com reservas. A relação entre candidatos evangélicos e seus eleitores seria, com frequência, caracterizada como deletéria para o sistema político ${ }^{12}$. A ascensão dos evangélicos poderia representar uma ameaça ao Estado laico.

Tais juízos permaneceram, em alguns casos, pouco discerníveis de meros juízos de valor. A ideia de que a relação de representação entre político evangélico e eleitor seja a de uma representação distorcida ou anômala não costuma ser adequadamente justificada. $\mathrm{O}$ uso de termos como «clientelismo», «rebanho eleitoral» e «currais eleitorais» nesse contexto é feito de modo acrítico. Em geral, assume-se que candidatos evangélicos controlam seus eleitores, recebem deles grande apoio eleitoral e estabelecem com eles relações clientelistas sem uma discussão conceitual mais rigorosa ou algum tipo de verificação empírica. O crescimento da população evangélica no Brasil torna essas suposições ainda mais problemáticas.

\footnotetext{
${ }^{11}$ Em 1970, 5,2\% dos brasileiros se declaravam evangélicos; em 2010, esse percentual saltou para 22,2\% (cf. Censo Demográfico 2010).

${ }^{12}$ Não seria um exagero dizer também que, no limite, está em questão o próprio estatuto epistêmico da fé e a decisão do eleitor religioso ou evangélico de atuar na política orientado por ela.
} 
O Brasil possui a quarta maior população evangélica do mundo ${ }^{13}$. De acordo com o último Censo, aproximadamente 42 milhões de brasileiros se declararam evangélicos em 2010. Uma pesquisa amostral do Instituto Datafolha realizada em dezembro de 2016 aponta que o percentual de evangélicos brasileiros já chegaria a $29 \%{ }^{14}$. O debate sobre os efeitos da mobilização política evangélica é, pois, de suma importância para a democracia brasileira. É, também, de suma importância para o mundo. O ativismo político evangélico é, em certo sentido, um caso relevante para uma discussão teórica mais geral, que diz respeito ao papel das religiões nas democracias liberais. Nas palavras de Eberle (2006):

«suppose we can expect, for the foreseeable future, that religion will retain its vitality in liberal democracies. That raises a crucial question: what problems can we realistically expect religion to pose for a liberal democracy?» (p. 26)

Assumo, pois, como um fato, que as democracias atuais testemunham o crescimento e a vitalidade de diversos grupos religiosos, e que muitos desses grupos buscam participar ativamente da vida política. No caso da América Latina, e do Brasil em particular, nenhum grupo religioso despertou tanto a atenção da mídia e da academia quanto os evangélicos e sua atuação política nas últimas três décadas. A mobilização política evangélica no Brasil se constitui, portanto, em importante objeto de estudo para responder à pergunta teórica sobre que papel podem desempenhar as religiões nas democracias. Porém, a presente pesquisa não é, ao menos em princípio, normativa. Meu objetivo é contribuir para a compreensão do fenômeno, e não emitir juízos - que seriam necessariamente precipitados - sobre a adequação ou não da participação política evangélica a um sistema democrático. Não acredito que a existência de evangélicos na política, ou mesmo de deputados representantes de igrejas pentecostais, contenha elementos por si sós suficientes para embasar um juízo sobre sua inadequação à democracia. Pode até mesmo ser o caso de que esse fenômeno seja responsável pelo aumento da representação política de uma considerável parcela da população, que, não fosse por isso, permaneceria não representada. De modo semelhante, não adoto as suposições - até agora pouco fundadas - de parte da literatura acadêmica de que a participação política evangélica seria clientelista, ou que candidatos evangélicos controlariam «rebanhos eleitorais» submissos. Pelo contrário. São suposições como essas que pretendo transformar em hipóteses de pesquisa.

\footnotetext{
${ }^{13}$ Pew Research Center (2011). Global Christianity: a Report on the Size and Distribution of the World's Christian Population. (Disponível em: <http://www.pewforum.org/2011/12/19/global-christianity-exec/>)

${ }^{14}$ «44\% dos evangélicos são ex-católicos», Datafolha, 28/12/16.
} 
Esta tese reúne quatro trabalhos independentes, conquanto relacionados entre si. Foram escritos para serem lidos e avaliados sem a necessidade de apoio um do outro. Todavia, a investigação de cada um deles guarda relação com a dos demais, de modo que, juntos, compõem uma unidade. O capítulo 1 apresenta uma revisão da literatura sobre crescimento pentecostal e política na América Latina, dando ênfase ao caso brasileiro. Divido a literatura em dois grandes grupos, um mais voltado para o continente latino-americano, e outro mais focado no Brasil. Em que pesem suas diferenças, dou destaque a um elemento comum aos dois grupos: a associação entre atuação política pentecostal e clientelismo. Depois de apresentar a literatura, argumento que tal associação deveria ser fundamentada num esforço conceitual e empírico mais aprofundado. De modo a justificar minha crítica, apresento alguns simples testes estatísticos baseados na produção de leis da Assembleia Legislativa do Estado de São Paulo. O esforço empírico, ressalto, é modesto e busca tão-somente iluminar a necessidade de maiores investigações sobre o tema, assim como ressaltar que a literatura pregressa, embora associe a atuação pentecostal a práticas clientelistas, não ofereceu fundamentos sólidos para tanto.

O capítulo 2 parte de uma discussão conceitual sobre o «candidato oficial pentecostal»e como ele se diferencia do candidato evangélico. A partir daí, apresento um conjunto de evidências baseadas num novo banco de dados de candidaturas evangélicas, usado neste capítulo e no seguinte. Busco entender o desempenho dos candidatos evangélicos nas eleições para o legislativo no Brasil. Argumento que, ao contrário do que o senso comum midiático dá a entender, não existe um crescimento relativo do número de candidatos evangélicos no Brasil, embora haja crescimento relativo da população evangélica. Em seguida, apresento dados que revelam que o aumento do número de candidatos evangélicos eleitos nos últimos anos se deve em larga medida ao sucesso de candidatos apoiados por igrejas pentecostais, sobretudo da Assembleia de Deus e da Igreja Universal do Reino de Deus. Por fim, tomo como unidade de análise as igrejas pentecostais, de modo a mostrar que, embora sua incursão eleitoral venha ganhando destaque na mídia e na academia, as igrejas não são bem-sucedidas como normalmente se assevera.

Isso não significa, é claro, que elas não possuam uma contribuição importante para o sucesso eleitoral dos candidatos pentecostais. No capítulo 3, investigo justamente o efeito de ser apoiado por uma igreja pentecostal sobre o voto dos candidatos ao legislativo no Brasil. A partir da literatura sobre pentecostais e política, assim como sobre os determinantes do sucesso dos candidatos ao legislativo, formulo hipóteses sobre a relação entre ser candidato pentecostal e o gasto de campanha, o número de votos e o tipo de igreja que o apoia. As hipóteses são testadas por meio de um banco de dados referente às eleições de 2014 para a Câmara dos Deputados e Assembleias Legislativas. A partir de modelos de regressão OLS, encontro evidências de que ser candidato pentecostal tem um efeito positivo sobre o gasto de campanha; tem um efeito 
igualmente positivo sobre o desempenho eleitoral (i.e., o número de votos); que candidatos pentecostais apresentam um desempenho distinto e superior ao de candidatos evangélicos; e que, por fim, o tipo de igreja faz diferença no efeito de ser pentecostal sobre o voto. Igrejas com maior estrutura e centralização, como a Universal, produzem mais votos para seus candidatos do que as demais.

No capítulo 4, examino o efeito que informações sobre a filiação evangélica dos candidatos podem ter sobre os eleitores. A competição eleitoral para os legislativos brasileiros se faz num ambiente complexo e de alto custo cognitivo para o eleitor. Nessas condições, e considerando a alta fragmentação do sistema partidário brasileiro, a criação relativamente recente dos partidos, e os níveis comparativamente baixos de identidade partidária, é plausível supor que eleitores se apoiem em «atalhos» informacionais para tomarem suas decisões. A partir de um experimento de survey realizado com estudantes universitários durante as eleições municipais de 2016, argumento que a pertença dos candidatos a grupos religiosos pode oferecer aos eleitores algum tipo de ajuda nesse sentido, produzindo algum tipo de identificação baseada no grupo social, ou, inversamente, uma rejeição pelo candidato membro de outro grupo. $\mathrm{O}$ uso, nas eleições legislativas recentes, por parte de um número crescente de candidatos evangélicos, de «pistas» para sinalizar aos eleitores sua identidade evangélica, pode ser explicado como uma estratégia para a dura competição eleitoral brasileira. Argumento, também, em consonância com a literatura recente, que essas «pistas» serão tanto mais importantes quanto maior for o número de candidatos.

Nas considerações finais, exploro as relações entre os diversos capítulos, destacando suas contribuições para a literatura sobre religião e política no Brasil e sugerindo novos caminhos de pesquisa. Os materiais complementares estão presentes como apêndices ao final da tese. $\mathrm{O}$ banco de dados utilizado nos capítulos 2 e 3, assim como o banco resultante do experimento de survey do capítulo 4, estão disponíveis para consulta e replicação das análises, bastando serem solicitados ao autor ${ }^{15}$.

${ }^{15} \mathrm{O}$ pedido ao autor pode ser feito para o e-mail flmds@usp.br. 


\section{Capítulo 1}

\section{Pentecostalismo e Política: uma Avaliação da Literatura Sobre América Latina e Brasil}

\section{Introdução}

As mudanças religiosas na América Latina ao longo do século XX ensejaram, a partir da década de 1960, um conjunto de estudos sobre as consequências do crescimento pentecostal para os países latino-americanos. O presente capítulo é, primeiramente, uma revisão dessa literatura enfatizando o caso brasileiro. Trata-se de uma revisão exaustiva, ainda que não cubra todos os trabalhos sobre o tema. Divido a literatura em dois grupos de trabalhos. O primeiro grupo é formado por trabalhos oriundos da antropologia e da sociologia da religião. Seu denominador comum é a tentativa de responder à pergunta sobre o impacto social e político do crescimento pentecostal para o continente latino-americano, ainda que haja uma preocupação implícita com as consequências desse crescimento para a própria religião protestante. Em geral, baseiam-se em pesquisa histórica, entrevistas e etnografias de um ou mais países da região. O segundo grupo é composto de trabalhos voltados para o caso brasileiro. Eles têm em comum o fato de serem informados pela experiência brasileira: a partir da redemocratização, a atuação política das igrejas pentecostais será cada vez mais identificada como uma atuação na arena eleitoral. Por conta disso, esses trabalhos se focam na mobilização eleitoral pentecostal e são, em geral, marcados por uma preocupação maior com as consequências da mobilização pentecostal para o sistema político brasileiro. Nesse grupo, há trabalhos oriundos da sociologia da religião e da ciência política.

Ambos os grupos, mas sobretudo o primeiro, fazem referência ao clientelismo como elemento presente na mobilização pentecostal. Em muitos casos, o clientelismo aparece como mecanismo explicativo da reprodução, por parte de igrejas pentecostais, de formas de dominação tradicionais. Questiono essa interpretação, argumentando que as referências a práticas clientelistas pentecostais, conquanto não necessariamente equivocadas, carecem de um esforço conceitual e empírico mais aprofundado. A associação entre clientelismo e pentecostalismo aparece na literatura como pressuposto, e não como hipótese. Ao final do capítulo, é apresentada uma análise simples da produção de leis da Assembleia Legislativa do Estado de São Paulo com o mero objetivo de ressaltar, primeiro, a necessidade de melhor definição conceitual sobre o que 
se entende por clientelismo, e segundo, a dificuldade de oferecer argumentos empíricos que confirmem a hipótese de que políticos pentecostais seriam clientelistas ou mais clientelistas do que os outros.

\section{As transformações religiosas na América Latina e no Brasil}

As mudanças religiosas na América Latina vêm chamando a atenção de cientistas sociais há décadas. Sem diminuir a importância de outros fenômenos, o surgimento historicamente recente de dois novos «atores» religiosos foi, talvez, o fato mais importante na literatura sobre religião na América Latina, e o que mais chamou a atenção de sociólogos, antropólogos e cientistas políticos, sobretudo por sua suposta relevância para a democracia e a ordem políticosocial dos países latino-americanos. Esses novos «atores» foram as comunidades eclesiais de base (CEBs), gestadas a partir da ascensão, dentro da Igreja Católica, da teologia da libertação; e as igrejas pentecostais, frutos de transformações oriundas do Protestantismo ${ }^{16}$.

As mudanças políticas e culturais ocorridas no mundo nas décadas de 1950 e 1960 repercutiram também na Igreja Católica, fazendo com que se gestasse, dentro dela, a corrente de inspiração marxista conhecida como teologia da libertação. Embora tenha se desenvolvido dentro do catolicismo ao longo de décadas, seu nascimento simbólico se deu em 1971, quando o padre peruano Gustavo Gutiérrez publicou seu livro Teología de la Liberación. Tendo Gutiérrez e o brasileiro Leonardo Boff como dois de seus mais conhecidos expoentes, a teologia da libertação influenciou consideravelmente o clero católico latino-americano. Em parte por isso, em parte pelas condições sociais da própria região, o catolicismo latino-americano e, em particular, o brasileiro, tornou-se, na visão de muitos acadêmicos, um dos mais progressistas do mundo (Mainwaring, 2004; Gill, 1994).

Impulsionados pela teologia da libertação, parte do clero e laicato católicos trabalhou na difusão das CEBs pelo Brasil. Embora nem todas as comunidades de base tenham sido fundadas a partir dos preceitos da teologia da libertação, certamente foram as influenciadas por ela as que se tornaram mais conhecidas (Gill, 2002). Segundo Burdick, «em nenhum lugar na América

\footnotetext{
${ }^{16}$ Sigo a definição de «pentecostalismo» de Mariano (2004): «o pentecostalismo distingue-se do protestantismo histórico, do qual é herdeiro, por pregar a crença na contemporaneidade dos dons do Espírito Santo, entre os quais se destacam os dons de línguas (glossolalia), cura e discernimento de espíritos, e por defender a retomada de crenças e práticas do cristianismo primitivo, como a cura de enfermos, a expulsão de demônios, a concessão divina de bênçãos e a realização de milagres.» (p. 134). O pentecostalismo pode ser classificado em três grupos. O primeiro é o do pentecostalismo clássico e abrange apenas as igrejas pioneiras: Congregação Cristã no Brasil e Assembleia de Deus, que se instalaram no país na década de 1910. O segundo grupo começou na década de 1950 e não tem um nome consensual, mas abriga a Igreja do Evangelho Quadrangular, Brasil Para Cristo, Deus é Amor, entre outras. De acordo com Mariano, esse grupo inaugura «o evangelismo focado na pregação da cura divina» (p. 123). O terceiro e último grupo é o do neopentecostalismo, que se inicia nos anos 1970 e tem como uma de suas características a teologia da prosperidade. É o grupo da Igreja Universal do Reino de Deus, Igreja Internacional da Graça de Deus, Sara Nossa Terra e Renascer em Cristo (idem).
} 
Latina as CEBs se tornaram tão numerosas ou receberam mais apoio oficial da hierarquia da Igreja que no Brasil»(1998, p. 11). As comunidades de base visavam aproximar os fiéis católicos, sobretudo os mais pobres, de uma leitura dos evangelhos orientada por uma visão de libertação política. Dado isso, era de se esperar que o desenvolvimento das CEBs no Brasil despertasse a atenção de intelectuais e cientistas sociais, sobretudo aqueles mais alinhados à esquerda. A literatura sobre religião e América Latina passou por grande desenvolvimento nesse período. No entanto, o entusiasmo acadêmico pelas CEBs teve de se defrontar com a relativa limitação delas. Desde o início, houve dificuldade para se mensurar o número de participantes das comunidades, entre outras razões pela própria falta de consenso sobre o que seriam as CEBs ou sobre como defini-las. Não obstante, qualquer que tenha sido o percentual da população brasileira ligada às CEBs, tal contingente foi sempre menor do que aquele ligado às igrejas pentecostais.

Embora tenha gerado considerável número de estudos, a influência da teologia da libertação e suas comunidades de base diminuiu gradativamente e, em vários sentidos, tornou-se limitada, frustrando a expectativa de acadêmicos progressistas que enxergavam nas CEBs a possibilidade da formação de «novos cidadãos» ou de uma «nova sociedade» (Levine, 2009; Ireland, 1999; Burdick, 1998; Smith, 1994; Mariz, 1992; Stoll, 1990). Do ponto de vista do número de fiéis, é possível que outro movimento da Igreja Católica, a Renovação Carismática, tenha sido mais bem-sucedida do que as CEBs (Stark e Smith, 2012). Se, porém, as CEBs e sua influência na política se tornaram gradativamente menos relevantes para as ciências sociais, o mesmo não pode ser dito do outro «ator» mencionado anteriormente: as igrejas pentecostais.

O cenário religioso latino-americano sofreu profundas transformações nas últimas décadas. No que se refere ao número de adeptos, até o início da segunda metade do século XX seu «mercado» era monopolizado pela Igreja Católica, sendo diminuta a participação de outros grupos. No entanto, em que pese a presença ainda forte do catolicismo na maioria da América Latina, não é mais possível falar em monopólio católico. Com uma rapidez notável, outros grupos religiosos (e não religiosos) vem crescendo na região, tendo até ultrapassado numericamente os católicos em alguns países.

O Brasil se tornou um caso ilustrativo dessa transformação recente. Tendo herdado o catolicismo como religião oficial do Estado - mantida como tal até a constituição da República , os católicos constituíam 99,7\% da população brasileira em 1872 (Censo Demográfico, 2010). Esse percentual diminuiu gradativamente, mas ainda era de 91,8\% em 1970. Nas últimas décadas, porém, o país testemunhou um declínio acentuado do número de católicos, acompanhado por um crescimento de outros grupos, sobretudo evangélicos e «sem religião». Para se ter uma ideia da magnitude das mudanças, os católicos ainda são maioria segundo o Censo 2010, mas não constituem mais do que 64,6\% da população. Os «sem religião» chegam a 
$8 \%$, e os evangélicos, a 22,2\%, divididos entre denominações pentecostais $(13,3 \%)$, históricas ${ }^{17}$ $(4,0 \%)$ e não determinadas $(4,8 \%)^{18}$. Ressalte-se que, além de se constituírem no maior grupo evangélico, os pentecostais são também os maiores responsáveis pelo crescimento evangélico no Brasil. Desde o início dos anos 1990, o ramo histórico do protestantismo vem declinando no Brasil; o que explica o crescimento do protestantismo brasileiro é a rápida expansão do pentecostalismo (Mariano, 1999b). Essa tendência não é uma especificidade brasileira, mas, ao contrário, pode ser vista alhures. Se em números absolutos, como disse Freston (2008), os países do chamado terceiro mundo representam hoje o «coração» do protestantismo, isso se deve em grande medida ao avanço pentecostal.

FIGURA 1. Percentual da população católica e protestante no Brasil (2010)

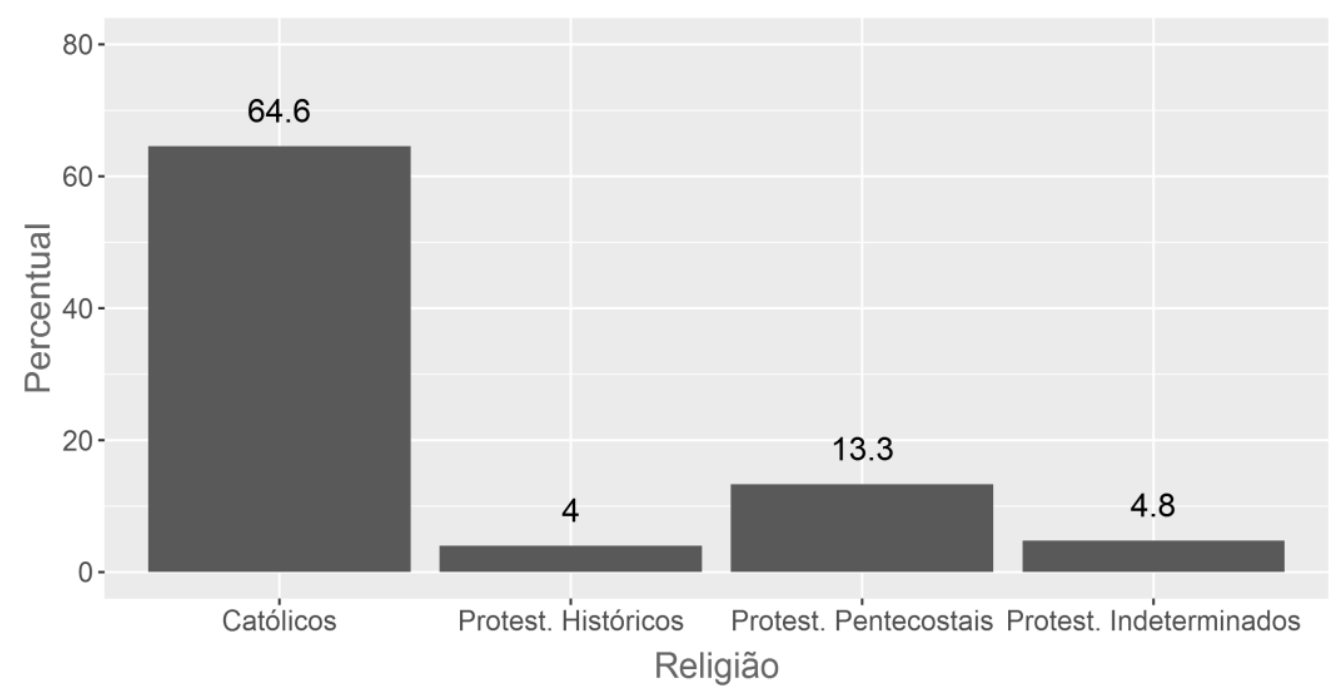

Fonte: Censo 2010

Desde o início do século XIX, o continente latino-americano foi alvo do esforço missionário protestante. Por volta de 1920, o número de missionários protestantes na América Latina superava 1.600 (Stark, 2001 apud Stark e Smith, 2012). Seu esforço evangelizador podia ser contrastado com a relativa falta de zelo da Igreja Católica na região; embora o catolicismo monopolizasse o «mercado» religioso latino-americano há séculos, tratava-se de um monopólio

\footnotetext{
${ }^{17}$ Por evangélicos históricos (ou de missão), entendo o ramo formado pelas igrejas Luterana, Presbiteriana, Anglicana, Metodista e Batista, entre outras (Mariano, 2004).

${ }^{18}$ Esses percentuais são muito próximos aos da América Latina considerada como um todo. Segundo o Americas Barometer Survey de 2012, 70\% dos latino-americanos são católicos, 19\% protestantes e 9\% declaram não ter filiação religiosa (Boas e Smith, 2013).
} 
débil e preguiçoso. No caso do Brasil, a situação da Igreja Católica era ainda pior do que a da América espanhola. No século XIX, a Igreja brasileira atingiu seu ponto mais baixo: o clero no país passava pouco tempo em atividades eclesiásticas, o número de padres e freiras diminuía desde 1855, quando o Estado proibiu novas admissões às ordens religiosas, e os seminários eram deficientes tanto do ponto de vista do número de ingressantes quanto da qualidade do ensino oferecido (Mainwaring, 2004). Com a ruptura entre Igreja e Estado corporificada na Constituição de 1891, iniciou-se certa reação por parte de círculos católicos, mas que se revelaria ineficaz para conter o futuro crescimento evangélico ${ }^{19}$.

Ao longo do século XX, a população evangélica cresceu na América Latina e no Brasil, em especial devido às igrejas pentecostais. A transformação religiosa na região encontrou paralelo em novos fatos ou fenômenos religiosos ocorridos em outras partes do mundo. Tome-se como exemplo a Revolução Iraniana de 1979 e sua proclamação de uma república islâmica; o papel assumido pela Igreja Católica no fim do regime comunista na Polônia; o crescimento da New Christian Right nos Estados Unidos; e o próprio papel da teologia da libertação na América Latina, entre outros (Gill, 2001). Esses fatos exemplificam a importância política que atores religiosos adquiriram na segunda metade do século XX. Se a irrupção desses fenômenos teve fortes consequências para o debate das ciências sociais, o mesmo se pode dizer, na América Latina, da ascensão pentecostal. Tal fato, somado ao declínio das CEBs já mencionado, transformou o protestantismo latino-americano (sobretudo o pentecostal) em objeto privilegiado de interesse da discussão acadêmica, em grande medida por suas implicações políticas.

\section{Crescimento pentecostal e política na América Latina}

Estudos mais sistemáticos sobre o protestantismo na América Latina só começaram a surgir a partir da década de 1960. Esses estudos buscavam responder à pergunta sobre as consequências do crescimento protestante (em particular pentecostal) para a região, e a grande

\footnotetext{
${ }^{19}$ Cabe ressaltar os esforços feitos pela Igreja Católica, sobretudo a partir da década de 1920, para tentar manter seu status diferenciado vis-à-vis as demais religiões (cf. Della Cava, 1976). Ao mesmo tempo, porém, não se deve perder de vista, que, a despeito de ser a religião majoritária, a força e influência da Igreja sobre a elite política eram relativas. Um exemplo ilustrativo é o da discussão ocorrida durante o governo de Arthur Bernardes (1922-1926) a respeito das emendas do deputado Plínio Marques. Na ocasião da revisão constitucional, Marques sugeriu a criação de duas emendas: a primeira tornava o ensino religioso facultativo, permitindo sua inclusão no currículo das escolas que a desejassem; a segunda tornava o catolicismo a religião oficial do Estado. Em que pesem possíveis «pressões» exercidas pela Igreja no caso, o então deputado Getúlio Vargas e mais cinquenta parlamentares assinaram documento contrário às medidas. Vargas criticou publicamente as «emendas católicas», como eram chamadas. A reação a elas contribuiu para a criação de Comitês Pró-Liberdade de Consciência, que reuníam evangélicos, maçons e positivistas (cf. Bica e Tambara, 2004). Apesar de as emendas de Plínio Marques terem sido derrotadas, Vargas, o mesmo que as criticara antes, aprovaria, na Constituição de 1934, o reconhecimento do casamento religioso, a proibição do divórcio e a educação religiosa nas escolas públicas, demandas da Igreja Católica (Della Cava, op. cit.). A influência do clero e laicato católicos no Brasil do início do século XX dependiam do contexto político e nem sempre resultavam em vitórias para a Igreja.
} 
maioria deu ao menos alguma atenção às consequências políticas. Porém, por partirem de um arcabouço teórico proveniente da antropologia e da sociologia da religião, esses trabalhos privilegiaram o estudo da própria religião (o protestantismo pentecostal, no caso) tanto ou mais do que as consequências políticas do seu crescimento. Sem menosprezar a importância de trabalhos de caráter historiográfico, foram os estudos seminais de Willems (1967) e d'Epinay (1970) os mais influentes na literatura das ciências sociais. Ambos se basearam na aplicação de questionários, técnicas de observação participante e extensa pesquisa bibliográfica.

A partir de estudo de campo realizado entre 1959 e 60 no Chile e Brasil, Willems investigou as mudanças culturais provenientes da expansão do protestantismo nesses países. Embora seu estudo não tenha como foco principal a política, o autor ainda assim dedica um capítulo ao comportamento político protestante. É interessante observar que, embora, como será enfatizado adiante, a Assembleia Constituinte marque um ponto de inflexão na participação política pentecostal no Brasil, Willems já observava, em 1960, sinais crescentes de participação política evangélica. Ao entrevistar 36 ministros protestantes brasileiros, diz que ao menos 34 legislativos municipais - a maior parte no estado de São Paulo - contariam com um ou mais representantes evangélicos (Idem, p. 233).

Willems apresenta uma visão assaz benigna sobre o impacto do crescimento evangélico no Brasil e no Chile, crescimento que poderia contribuir para uma maior mobilidade social e para o relaxamento das rígidas estruturas de classe dos dois países. Sua conclusão é que, exceção feita às igrejas pentecostais, ainda em sua maioria avessas à política, os evangélicos estariam participando cada vez mais politicamente. E conclui: «[i]n both countries, Protestantism has contributed to a strengthening of democratic principles» (p. 252).

Em contraste à visão de Willems, o trabalho de d'Epinay, publicado em 1968, oferece uma perspectiva consideravelmente menos otimista. Baseado em seu trabalho de campo no Chile, d'Epinay busca entender o impacto do pentecostalismo no desenvolvimento chileno e, por extensão, latino-americano. O Chile da primeira metade do século XX seria marcado pelo declínio da sociedade rural e pela erosão da antiga estrutura de hacienda, gerando um desenraizamento das massas populares sem sua concomitante e adequada reabsorção. Isso configuraria um estado durkheimiano de anomia (Durkheim, 1999). Para d'Epinay, seria essa situação de abandono à qual foram sujeitadas as massas que abriria o caminho para um estado psicológico de frustração, que, por sua vez, tornaria esses indivíduos receptivos ao pentecostalismo.

O pentecostalismo se ofereceria como alternativa única devido ao seu paralelismo com o sitema social da hacienda. No sistema de hacienda, 
«onde o poder se acha centralizado nas mãos do hacendado e onde as relações estão personalizadas, o indivíduo (peão, inquilino) não entra em relação com o Estado-nação a não ser indiretamente, enquanto cliente do proprietário (...), de quem receberá e seguirá as diretrizes políticas.» (Idem, p. 208)

No sistema de hacienda, a existência política do pobre rural não seria outra do que fazer parte da clientela do hacendado. Ao contrário do que se poderia pensar, a comunidade pentecostal não representaria uma ruptura a esse sistema, senão antes sua continuidade. O pastor ocuparia agora o papel do hacendado (proprietário de terra), controlando a nova clientela (os fiéis) e assumindo o papel de agente intermediário entre seu grupo e a sociedade. Percebendo isso, os chefes dos partidos políticos se dirigiriam agora ao pastor, «assinalando as vantagens que obteriam ele e sua igreja se os fiéis votassem por tal partido» (idem, p. 208).

Ao contrário de Willems, a posição de d'Epinay em relação ao pentecostalismo é pessimista, ainda que suas observações sempre reiterem a cautela que o leitor deve ter ao extrapolar suas conclusões para outros cenários. A visão apresentada por d'Epinay sobre as comunidades pentecostais é a de agrupamentos avessos à participação política e a qualquer contato com o «mundo», organizados em relações autoritárias e paternalistas, e que ofereceriam continuidade à ordem tradicional da hacienda. Dado tudo isso, conclui ele, «será duvidoso considerar o pentecostalismo como fator positivo de transição que capacite o indivíduo para o exercício da responsabilidade na sociedade moderna» (idem, p. 211).

A despeito dos méritos de ambos os trabalhos, e não obstante a cautela de ambos em generalizar suas conclusões, parece oportuno ressaltar que a participação política das comunidades pentecostais latino-americanas na década de 1960, apresentadas por Willems e d'Epinay, é bastante diferente daquela existente no fim do século XX e início do XXI. Se, em 1960, predominava uma forte rejeição à política, a partir das décadas de 1980 e 90 a maior parte das grandes igrejas pentecostais (ao menos no caso do Brasil) passam a participar ativamente da política eleitoral e partidária ${ }^{20}$.

Diferentemente de Willems e d'Epinay, que se debruçaram sobre um ou dois países, Martin (1990) analisa uma série de estudos de casos latino-americanos, o que lhe permite ter uma perspectiva mais abrangente sobre a região. Embora focado na «explosão protestante», Martin dedica atenção às consequências econômicas e políticas da ascensão protestante (sobretudo pentecostal) no continente. De modo geral, a hipótese de um impacto econômico decorrente do crescimento pentecostal deriva vagamente de Weber (2004) e seu clássico sobre o ethos protestante. Porém, o debate weberiano se focava no calvinismo; não é claro até que ponto a

\footnotetext{
${ }^{20}$ No caso do Brasil, a Congregação Cristã e a Deus É Amor são as únicas entre as maiores igrejas pentecostais a não lançar candidatos nas eleições. Mesmo assim, elas não condenam a participação eleitoral dos fiéis.
} 
relação poderia ser mantida para outros ramos protestantes, e, em particular, para o pentecostalismo. É, no mínimo, questionável a suposição de que o ramo pentecostal do protestantismo teria o mesmo caráter supostamente modernizador que teve o protestantismo histórico (Mariano, 1999b).

No que se refere às consequências políticas do pentecostalismo, Martin adota uma posição moderada, sem especificar claramente como tais consequências se dariam, e ressaltando que elas dependeriam de outras variáveis contextuais ${ }^{21}$. O autor observa que, mesmo não sendo direto, o impacto político resultante do crescimento pentecostal será influenciado pelas práticas estabelecidas na dinâmica política da região em questão. No caso da América Latina, diz ele, seriam o autoritarismo e o clientelismo (Martin, 1990, 1999). Sobre o interesse dos pentecostais brasileiros com a política, por exemplo, Martin afirma que, em geral, «it can be said that such interest as Pentecostals show in politics is of a piece with Brazilian political life as a whole: votes given by clients to patrons for services rendered» (1990, p. 67). Ainda assim, Martin ressalta como positiva a possibilidade da criação de «fraternal networks» e de associações voluntárias por parte das comunidades pentecostais. Essas, mais do que a doutrina pentecostal, poderiam ter consequências importantes para a ordem social latino-americana.

Stoll (1990), Mariz (1992, 1994), Smith (1994) e Burdick (1998) estabelecem algum tipo de comparação entre as igrejas pentecostais e as CEBs. A preocupação central de Stoll (1990) é o crescimento evangélico na América Latina e sua suposta relação com a política externa dos EUA. Ainda assim, ao comparar os dois «atores» religiosos, observa que as comunidades pentecostais prosperam mais do que as CEBs. Ainda que reconheça a visão negativa da literatura sobre o que seria a estrutura organizacional das igrejas pentecostais, bem como sobre as consequências de sua expansão para a América Latina, Stoll elenca alguns elementos do pentecostalismo que poderiam contribuir para o desenvolvimento da região, tais como a promoção da responsabilidade individual e a criação de organizações civis estáveis e independentes.

Mariz (1992) questiona a hipótese de que as CEBs e as igrejas pentecostais produziriam impactos políticos e econômicos distintos na América Latina. Baseando-se em trabalho de campo realizado no Brasil, ela argumenta que ambas contribuem para um aumento da autoestima dos seus membros, além de propiciar redes de apoio e fomentar habilidades de liderança.

\footnotetext{
${ }^{21}$ Referindo-se ao impacto do pentecostalismo, Martin diz que ele «varies according to the local channel most receptive to it, and this is true both economically and politically. In certain circumstances the impact may be translated in terms of a dispossessed group in a backward social condition seeking a measure of autonomy and, maybe, redress. At another time the translation may be made in terms of binding up distressed and/or isolated person, restoring the family or offering new ties of religious kinship. In yet other instances, [Pentecostalism] may be aligned with an ethnic identity. It can provide a shelter from the rigours of very rapid social and economic change» (idem, p. 231).
} 
Tudo isso poderia facilitar a mobilidade social e ajudar os membros a defender seus interesses na arena política.

Em trabalho posterior, Mariz (1994) desenvolve sua análise e dedica parte de sua atenção ao esforço de mobilização política de igrejas pentecostais, CEBs e religiões afro-brasileiras. A visão de Mariz é que o Estado brasileiro possuiria uma «estrutura clientelista» (p. 103). A crescente participação eleitoral dos mais pobres a partir da Constituição de 1988 teria permanecido presa a um «sistema de patronagem»; ao se mobilizar e atuar na política, as igrejas pentecostais reforçariam tal estrutura, adotando «comportamentos clientelistas» (p. 110). Mariz não é clara sobre o que exatamente constituiria esse comportamento, mas dá a entender que ele ocorreria porque os políticos evangélicos defenderiam os interesses das próprias igrejas. Apesar disso, Mariz mais uma vez questiona as intepretações de que o crescimento das CEBs produziria consequências muito diferentes do das igrejas pentecostais. Seu argumento é que, a despeito das diferenças de valores, tanto CEBs quanto igrejas pentecostais contribuem para um processo de racionalização religiosa, além de fomentar a criação de novos vínculos e organizações.

Smith (1994) também compara as consequências das CEBs e das igrejas pentecostais para as democracias latino-americanas. Baseando-se numa ideia bastante questionável de que a América Latina possuiria uma cultura política ibérica nociva à democracia ${ }^{22}$, Smith argumenta que, no longo prazo, as CEBs terão papel pouco relevante, ao passo que as igrejas pentecostais podem vir a ter um papel importante na consolidação democrática da região. Porém, assim como a maior parte da literatura, Smith não apresenta claramente os mecanismos por meio dos quais o crescimento pentecostal afetaria a política latino-americana. As suposições levantadas por ele são que a expansão pentecostal poderia fortalecer a sociedade civil, encorajar o surgimento de novas lideranças e promover entre seus membros um respeito pela rule of law.

Publicado em 1996, o trabalho de Burdick (1998) tem como foco as CEBs no Brasil, e, a partir daí, estabelece uma comparação entre elas e as igrejas pentecostais. A partir de pesquisa etnográfica realizada em uma comunidade da Baixada Fluminense, Burdick questiona o potencial político progressista das CEBs, mas também a ideia de que as igrejas pentecostais seriam necessariamente apolíticas ou contrárias à luta por direitos dos mais pobres. Embora retratadas pela literatura como organizações conservadoras e submissas à autoridade e à ordem existente, Burdick relativiza essa ideia, observando que o não-engajamento dos pentecostais se explicaria, ao menos parcialmente, por certa segregação social (eram mais pobres do que o resto da comunidade).

Assim como a maior parte dos trabalhos citados, o de Bastian (1994) tem como objetivo o estudo do impacto social e político do protestantismo na América Latina. Para tanto, adota uma

\footnotetext{
${ }^{22}$ Segundo Smith (1994), a cultura política ibérica, dominante na América Latina, seria marcada por autoritarismo, elitismo, clientelismo e patrimonialismo.
} 
perspectiva histórica e linear que se inicia na época colonial e vai até os tempos atuais. Bastian tenta expandir a análise de d'Epinay para toda a região latino-americana. Sua visão sobre o pentecostalismo é consideravelmente negativa, entendendo as igrejas pentecostais como instrumentos de dominação. O trecho a seguir é ilustrativo:

«En la zona rural y también en el medio suburbano, el pentecostalismo no atrae como portador de um proyecto moderno de reforma religiosa, política y social que combata las desigualdades. Todo lo contrario, su exito se deve a la enorme capacidad que ha demonstrado para servir de apoyo a una mescolanza religiosa sincrética que fortalece el imaginario y las formas tradicionales de dominación.» (p. 254)

As igrejas pentecostais multiplicariam «modelos autoritarios de control social»; o ascetismo pentecostal não teria uma motivação ética, mas sim política, de rechaço aos chefes locais ligados ao catolicismo (para suplantá-los por chefes pentecostais, subentenda-se). O crescente envolvimento das igrejas pentecostais na política é explicado por Bastian de modo simplista como o resultado natural do crescimento do número de fiéis das igrejas, já que o grande número de votos representado pelos fiéis se constituiria num meio eficaz para a realização de negociações clientelistas entre os líderes das igreja e os políticos (p. 268). Bastian usa como exemplo o apoio que igrejas pentecostais teriam dado a ditaduras militares latino-americanas, citando especificamente os casos chileno e brasileiro ${ }^{23}$.

Seguindo a linha pessimista, Chesnut (1997) busca responder por que o pentecostalismo teria um sucesso tão grande entre os pobres no Brasil e na América Latina. Seu trabalho se baseia em estudo de campo realizado no estado brasileiro do Pará e se foca na Assembleia de Deus (AD). O crescimento do pentecostalismo se explicaria pela eficácia da cura pela fé pentecostal de doenças decorrentes da pobreza. Embora seja essa a explicação principal, Chesnut incorpora uma explicação secundária para o sucesso pentecostal: o crescimento do poder político da AD e sua relação com o Estado brasileiro.

Chesnut questiona a ideia de um «rebanho eleitoral» obediente e dócil ao pastor. Tal imagem não faria jus à realidade. No entanto, apresenta a $\mathrm{AD}$ como uma igreja autoritária, sem deixar claro até que ponto esse seria um juízo meramente descritivo (i.e., autoritária porque organizada a partir de uma estrutura hierárquica) ou um juízo normativo. Para Chesnut,

\footnotetext{
${ }^{23}$ É interessante observar que, para Bastian, o pentecostalismo não seria tanto uma continuidade do protestantismo histórico - de cultura supostamente liberal e democrática -, mas sim do catolicismo popular - de cultura supostamente corporativista e politicamente passiva.
} 
«Brazilian Pentecostalism reinforces the political status quo by engaging in the clientelistic politics that predominate in the republic. Although religious and political ideology plays a role, personal and institutional interests form the core of Pentecostal politics.» (p. 146)

Mais uma vez, há uma associação direta e explícita entre mobilização política pentecostal e clientelismo. É verdade que não se trata de uma afirmação de que políticos pentecostais sejam mais clientelistas do que os outros, e sim de que o são tanto quanto os outros. De todo modo, os exemplos dados por Chesnut para ilustrar as relações clientelistas entre políticos da AD e sua clientela são, na sua quase totalidade, exemplos de pork barrel, isto é, políticas paroquiais. Nessa visão, pork é igualado a clientelismo. A análise de Chesnut dá a entender que o esforço da $\mathrm{AD}$ por eleger representantes da própria igreja seria apenas a continuação de um esforço para manter práticas clientelistas.

De modo semelhante à maior parte da literatura supracitada, Gaskill (1997) se pergunta sobre o papel que o protestantismo irá desempenhar nas democracias latino-americanas. Embora observe que o protestantismo poderia ter algum efeito sobre as democracias da região por meio de um impacto no crescimento econômico, Gaskill argumenta que esse não parece ser o caso. As especificidades teológicas do pentecostalismo não proporcionariam a criação de um ethos protestante semelhante ao que teria contribuído para o espírito do capitalismo na famosa narrativa weberiana.

De modo semelhante aos outros autores, Gaskill afirma que, na América Latina, igrejas pentecostais participam em redes de patronagem que sustentam governos populistas e que algumas delas demonstraram propensão a apoiar governos autoritários (casos de Brasil, Chile e Argentina). No entanto, em que pesem as semelhanças, a análise de Gaskill difere das demais num aspecto importante. É, dentre todos os autores citados até aqui, um dos únicos a incorporar insights da teoria da economia religiosa (cf. Stark e Iannaccone 1994) e a priorizar uma análise de caráter mais institucional. Seu argumento básico é que o crescimento protestante abriria o mercado religioso para uma competição inter-denominações. Os líderes evangélicos precisariam, num contexto de mercado competitivo, preservar e expandir sua base organizacional. A necessidade de crescimento e sobrevivência criaria incentivos para os pastores se tornarem empreendedores religiosos, o que os levaria a um comportamento clientelista, visto que esses pastores teriam de buscar recursos no Estado.

A despeito de seus méritos, a análise de Gaskill apresenta algumas lacunas. Em primeiro lugar, como a maior parte da literatura resenhada, usa o conceito de clientelismo de forma vaga e imprecisa. Gaskill não apresenta evidências de um comportamento clientelista por parte dos grupos pentecostais, apenas assume que assim seja. Em segundo lugar, ignora que, embora sua explicação se adeque a boa parte das maiores igrejas pentecostais, não explica a atuação de todas 
elas, nem das maiores, nem das menores. Gaskill postula que, por conta do mercado religioso competitivo e da estrutura política das democracias latino-americanas, os líderes pentecostais teriam fortes incentivos institucionais para atuar de forma clientelista, frustrando, em sua visão, uma participação política mais democrática (p. 88). Assim, no limite, a mobilização política pentecostal seria nociva à democracia.

Como os demais pesquisadores, Dodson (1997) também procura contribuir para responder à pergunta sobre como a expansão do pentecostalismo afetará as democracias latinoamericanas. Porém, ao contrário de Gaskill, apresenta uma perspectiva mais otimista. Dodson resgata a análise de Tocqueville sobre a relação entre religião e liberdade nos Estados Unidos e se pergunta se o mesmo não poderia ocorrer com o pentecostalismo na América Latina. Ele argumenta que a apatia política não é uma característica necessária das igrejas pentecostais. Para Dodson, o crescimento do pentecostalismo poderia impactar positivamente as democracias por meio de um maior «senso de pertencimento» dos convertidos, pela promoção da igualdade de condições (algo supostamente presente nas comunidades pentecostais) e por meio do fortalecimento da sociedade civil.

De forma geralmente explícita, mas por vezes implícita, a literatura abordada aqui busca responder a uma mesma pergunta: qual seria o impacto social e político do crescimento protestante - sobretudo pentecostal - nos países latino-americanos? As respostas têm um teor normativo. Autores como Willems (1967), Stoll (1990), Martin (1990), Mariz (1992), Smith (1994) e Dodson (1997) enxergam de maneira positiva a relação entre pentecostalismo e política. Trata-se de uma perspectiva sutil, mas que se baseia na ideia de que o pentecostalismo teria o potencial de promover novas lideranças e fortalecer a sociedade civil por meio da criação de novos vínculos e organizações. Em contrapartida, d’Epinay (1970), Bastian (1994), Chesnut (1997) e Gaskill (1997) apontam para uma perspectiva pessimista, ressaltando o modo como as igrejas pentecostais ingressariam na política adotando práticas clientelistas potencialmente nocivas à democracia.

Os trabalhos aqui analisados trouxeram um considerável ganho para a compreensão das consequências do crescimento pentecostal latino-americano. A simplificação das comunidades pentecostais como inerentemente nocivas à democracia foi bastante questionada, ainda que apenas por alguns autores. A ideia de que pentecostais seriam essencialmente avessos à participação política também foi paulatinamente colocada em questão. $O$ afastamento da política não teria uma base necessariamente teológica, sendo explicado, antes, por outras razões, tais como a segregação social (cf. Burdick 1998). Uma série de consequências positivas advindas do crescimento pentecostal foi aventada por esses autores, ainda que sem um maior aprofundamento empírico. Por fim, vale a pena ressaltar a relação estabelecida por Gaskill (1997) entre a pluralização do mercado religioso e a criação de incentivos institucionais para líderes 
pentecostais adentrarem o campo político-eleitoral. Com a abertura desse mercado, as igrejas entrariam numa competição inter-denominações, recebendo um forte incentivo para buscar recursos estatais.

A despeito dos méritos e ganhos trazidos por esses trabalhos, seria interessante fazer também algumas observações gerais sobre suas relativas limitações. Em primeiro lugar, embora a pergunta sobre o impacto social e político do pentecostalismo na América Latina (ou em algum país específico) seja relevante, ela é assaz vaga. Tal impacto poderia se dar de forma direta ou indireta e, nesse caso, de diversas formas diferentes. Mesmo aqueles autores abordados aqui que se referem especificamente a um impacto político, ainda assim o fazem buscando responder quais seriam as «consequências políticas» do pentecostalismo para as democracias latinoamericanas. Trabalhos como os de d'Epinay (1970), Martin (1990), Smith (1994) e outros estão, talvez, mais preocupados com as consequências do crescimento pentecostal para o próprio protestantismo do que com as consequências para os sistemas políticos latino-americanos.

Em segundo lugar, cabe observar que a grande maioria dos trabalhos mencionados tipifica o comportamento das igrejas pentecostais como clientelista. Voltarei a esse tema adiante; por ora, basta ressaltar que essa tipificação é feita sem nenhuma discussão conceitual ou empírica mais aprofundada. O termo «clientelismo» parece ser usado no sentido vago de apropriação privada do bem público. Em alguns dos trabalhos, a atuação clientelista pentecostal apenas reforçaria uma suposta cultura política latina que já é, ela mesma, clientelista (cf. Smith, 1994; Chesnut, 1997). A atuação clientelista promoveria as estruturas de dominação existentes e embasaria, em grande medida, os diagnósticos de que o crescimento pentecostal prejudica a democracia na América Latina.

Em terceiro lugar, a literatura em questão dá relativamente pouca atenção às causas do crescimento pentecostal na América Latina. Quando o faz, geralmente se apoia na hipótese da anomia, segundo a qual mudanças sociais dramáticas (urbanização, industrialização, etc.) retirariam as pessoas de suas comunidades tradicionais e ensejariam uma maior demanda por religião. A ideia subjacente é que pessoas em condição frágil ou precária buscariam a religião como algum tipo de refúgio (cf. d'Epinay, 1970) ${ }^{24}$. A discussão sobre as causas do crescimento pentecostal é relevante por, entre outras coisas, colocar em evidência a «formação das preferências» dos pentecostais. A suposição de que a causa do pentecostalismo seria a anomia social leva ao questionamento da legitimidade das «preferências» pentecostais, servindo melhor à caracterização das igrejas pentecostais como clientelistas e à ideia de que a inserção protestante na política seria ilegítima. Ao sofrerem os efeitos da modernização, indivíduos em situação social e psicológica precária seriam atraídos e cooptados pelas igrejas pentecostais. Se, porém, os

\footnotetext{
${ }^{24}$ Um dos poucos trabalhos a investigar a causa do crescimento pentecostal na América Latina é o de Gill (1999).
} 
mecanismos explicativos para a conversão ao pentecostalismo fossem outros, e as preferências dos pentecostais fossem tomadas como legítimas (ou, simplesmente, como exógenas ao modelo explicativo), e não como uma «falsa consciência» da realidade, então a narrativa da literatura perderia parte de seu poder de convencimento.

Em quarto e último lugar, a literatura sobre pentecostalismo e política na América Latina se dedica excessivamente ao «impacto» ou «potencial» de longo prazo do crescimento protestante $^{25}$. Embora esse tipo de consideração seja relevante, a literatura teria muito a ganhar se falasse não apenas das conjecturas sobre o que o pentecostalismo na política será, ou sobre o que ele deveria ser, mas também sobre o que de fato é. O presente trabalho se orienta nessa perspectiva. Na próxima seção, passarei à revisão de um segundo conjunto de trabalhos, esses mais focados no caso brasileiro.

\section{Crescimento pentecostal e política no Brasil}

Os estudos abordados na seção anterior tinham como denominador comum a tentativa de responder à pergunta sobre o impacto social e político do crescimento pentecostal na América Latina. Partindo em geral de um arcabouço teórico antropológico ou sociológico, esses trabalhos se basearam em pesquisa histórica, revisão de literatura, estudos de campo e etnografias dos países latino-americanos para traçar um panorama da região. A questão para a qual buscavam contribuir era consideravelmente ampla. O clientelismo aparece como o principal mecanismo explicativo da reprodução, por parte das igrejas pentecostais, das formas tradicionais de dominação. O conceito, porém, é usado de modo impreciso. Por fim, esses trabalhos se dedicam consideravelmente à reflexão sobre o impacto «futuro» ou de «longo prazo» do crescimento pentecostal, sem um maior esforço para a compreensão empírica sobre como se dá esse impacto, nem para a compreensão das consequências especificamente políticas de tal crescimento.

As mudanças sociais e políticas ocorridas no Brasil no final do século XX e, em particular, nos anos 1980 e 90, ensejaram o surgimento de um conjunto de trabalhos que, embora também investigue a relação entre pentecostalismo e política, possui certas especificidades em relação à literatura anterior. O crescimento evangélico notável ocorrido no Brasil, associado à Assembleia Constituinte de 1987-88, ao processo de redemocratização, às transformações internas no próprio campo evangélico, e, por fim, às características do sistema eleitoral brasileiro, contribuíram para que um novo panorama se desenhasse na relação entre protestantismo e política no Brasil. Da Constituinte em diante, a presença protestante se fez marcante na política e sobretudo nas eleições. Esse fenômeno ensejou um pequeno, porém

\footnotetext{
${ }^{25}$ Essa observação foi feita por Freston (1999).
} 
importante número de estudos, que, focados no caso brasileiro, apresentam novas descobertas e novas abordagens teóricas e de métodos em relação à literatura analisada anteriormente.

Até 1986, os evangélicos - fossem históricos ou pentecostais - tiveram presença discreta na política brasileira. Segundo Campos (2005), apenas dois deputados federais, o batista Luiz Alexandre de Oliveira, de Mato Grosso, e o metodista Guaracy Silveira, de São Paulo, teriam sido eleitos antes de 1945. Os pentecostais só ingressaram na política na metade dos anos 1960, com a eleição, em São Paulo, dos pastores Levy Tavares (deputado federal) e Geraldino dos Santos (estadual), ambos da Igreja O Brasil para Cristo. Na mesma época, em Minas Gerais, João Gomes Moreira, da Assembleia de Deus, foi eleito deputado estadual. Willems (1967) menciona que, em 1960, quatro membros da Câmara dos Deputados eram protestantes, representando quatro diferentes partidos. Segundo Freston (1993), apenas dez parlamentares evangélicos teriam sido eleitos para a legislatura de 1963-1967 do Congresso brasileiro (ver figura abaixo). Diante desses números aparentemente modestos, a Assembleia Constituinte (AC) inaugurou uma nova era para os evangélicos na política, cuja atuação foi cada vez mais marcada pelas igrejas pentecostais. Foram eleitos 32 evangélicos para a AC, sendo 18 deles pentecostais (Freston, 1993). A presença evangélica na Constituinte e sua crescente participação nas eleições brasileiras explicaria por que a arena eleitoral teria se tornado objeto privilegiado dos estudos sobre evangélicos e política no Brasil.

FIGURA 2. Número de deputados federais evangélicos eleitos (1946-1991)

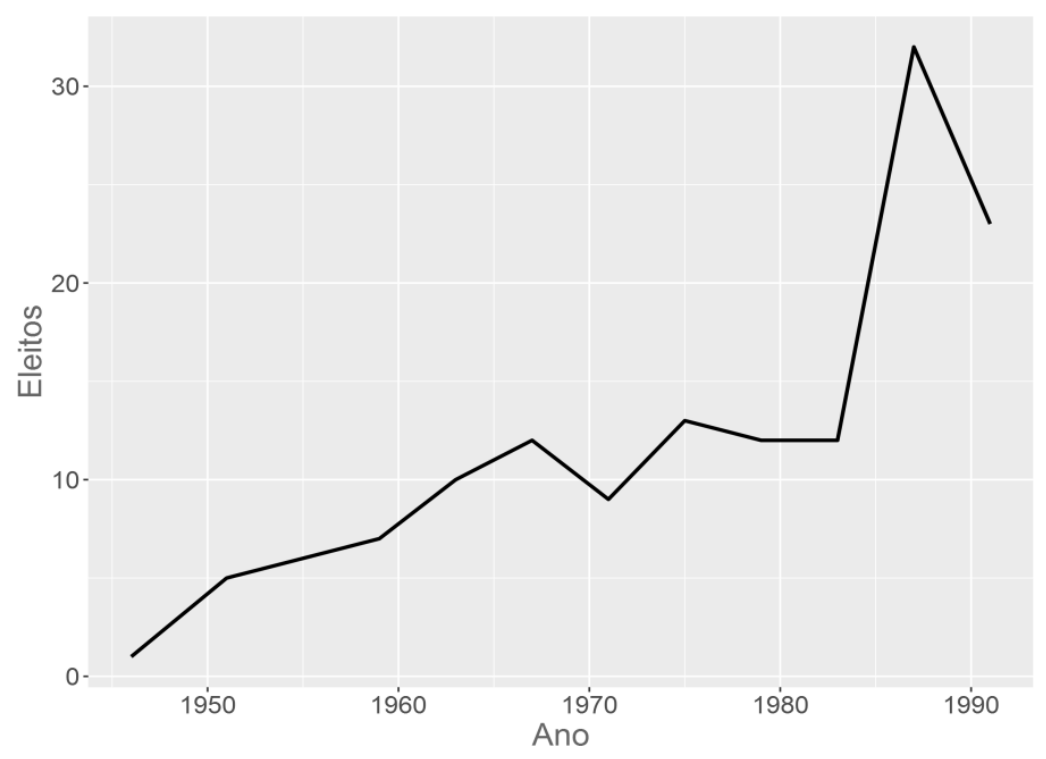

Fonte: Freston (1993: 167). 
Um dos primeiros estudos sobre o perfil da «bancada evangélica» na Constituinte foi o de Pierucci (1989). O trabalho se baseia em matérias de jornais e revistas e faz parte de um esforço maior do autor para investigar a direita política no Brasil. Pierucci reconhece que, dentre os parlamentares evangélicos, nem todos seriam conservadores, havendo alguns identificados com a esquerda. A referência a uma bancada evangélica política e ideologicamente homogênea é, portanto, bastante questionável. A análise de Pierucci contém alguns juízos de valor e críticas aos evangélicos por suas posições morais supostamente conservadoras, bem como por seu fisiologismo.

Mariano e Pierucci (1992) também ressaltam o crescimento evangélico na Constituinte e a existência de uma esquerda evangélica, que, embora pequena, não permitiria tomar a bancada evangélica como um bloco homogêneo. A pergunta central dos autores é como (ou por que) os evangélicos apoiaram Collor nas eleições presidenciais de 1989. A hipótese aventada é que Lula teria provocado medo entre os evangélicos por ser visto como um candidato radical e comunista. Além do medo do comunismo, muitos evangélicos achavam que Lula e o PT eram apoiados pela Igreja Católica, e que um eventual governo petista ameaçaria a liberdade religiosa e de culto.

Utilizando-se de entrevistas com líderes evangélicos, questionários aplicados a eleitores e certa pesquisa histórica, o trabalho de Freston (1993) é, talvez, o mais importante esforço sistemático de compreensão da relação entre evangélicos e política no Brasil da década de 1990. Seu foco é a participação evangélica na política eleitoral e parlamentar de 1986 até o impeachment do presidente Fernando Collor de Mello, em 1992, atentando tanto às consequências dessa participação para a política brasileira, como ao próprio campo evangélico. Freston ressalta o viés negativo do tratamento dado aos evangélicos pela mídia e a maior parte da academia. Sua conclusão é que o pentecostalismo brasileiro não tem uma visão universalista da política, não tem projeto de sociedade e nem é semelhante à New Christian Right americana. A elite política evangélica brasileira (da época considerada) não parece ser mais corrupta do que a média dos deputados, embora seja tão ou mais fisiológica ${ }^{26}$.

Não obstante tudo isso, a mais importante contribuição de Freston é sua atenção dedicada ao fenômeno das «candidaturas oficiais» pentecostais (p. 180). Freston é, salvo engano, o primeiro a considerar o fenômeno de modo mais analítico (dedica a ele dois capítulos de sua tese) e o primeiro a perceber sua importância. Posteriormente, outros autores também farão referência a ele, ainda que usando termos correlatos: «candidatos da igreja» (Miranda, 2006),

\footnotetext{
${ }^{26}$ Para Freston, «[o] fisiologismo reflete o conceito sectário de missão. Para garantir as condições de funcionamento, alianças com não-membros em posições de poder 'no mundo' são aceitas. Não se trata de ingenuidade ante o poder, mas de um pragmatismo autorizado pela visão sectária. O comprometimento do voto em troca de benefícios para a igreja, por exemplo, não é traição à mensagem; antes, o benefício recebido é quase um imposto que o poder 'mundano' paga à verdade.» (p. 286).
} 
«projetos corporativos eleitorais» (Baptista, 2007) e «modelo corporativo de representação política» (Machado e Burity, 2014).

É esse novo modo de inserção eleitoral evangélica que explicaria o grande crescimento do grupo na Constituinte e nas eleições seguintes. Para Freston,

«a irrupção pentecostal não é fruto de iniciativas descoordenadas. Quase a metade dos parlamentares protestantes pós-1987 são candidatos oficiais de igrejas pentecostais, uma modalidade praticamente inédita.» (p. 179, grifo meu)

A Assembleia de Deus foi a primeira igreja evangélica a adotar as candidaturas corporativas para a Constituinte. A decisão da cúpula da igreja para fazê-lo teria sido tomada já antes da Convenção Geral de janeiro de 1985, em Anápolis, GO. A Igreja do Evangelho Quadrangular (IEQ) teria seguido o exemplo, e, em sua Convenção no mesmo ano, optou pela apresentação de candidatos oficiais (p. 211). A Igreja Universal do Reino de Deus (IURD) seguiria a mesma estratégia, embora sua presença tenha se feito sentir sobretudo após a Constituinte.

Segundo Freston, as causas que explicam o surgimento das «candidaturas oficiais» pentecostais não seriam teológicas. Elas estariam relacionadas, antes, aos interesses dos próprios pastores pentecostais, que buscariam se fortalecer diante de sua igreja e no próprio campo evangélico; à busca dos líderes pentecostais por maior influência na vida pública e por recursos públicos para um grupo social em franca expansão no Brasil; e à tentativa de reagir a mudanças de valores e costumes no ambiente social brasileiro vistas como uma ameaça à socialização evangélica $^{27}$. Freston também observa que o sistema eleitoral brasileiro - representação proporcional de lista aberta - e a alta fragmentação partidária teriam facilitado a inserção político-partidária pentecostal. Ao mesmo tempo, essa inserção iria ao encontro dos interesses dos líderes partidários brasileiros, ansiosos por «diversificar suas clientelas» (p. 218).

Como a maior parte da literatura que se perguntou sobre o impacto do crescimento pentecostal na América Latina, bem como sobre a literatura mais focada no caso brasileiro, Freston também incorpora o clientelismo (por vezes chamado de fisiologismo) em sua explicação sobre a «irrupção pentecostal». Embora o conceito não tenha em seu trabalho a importância explicativa que adquire nos trabalhos pregressos, ainda assim Freston caracteriza a inserção pentecostal como clientelista. O cenário da redemocratização no Brasil, somado às

\footnotetext{
27 «Com a redemocratização, ficou patente o cacife eleitoral evangélico. O tamanho numérico e a expansão rápida já seriam motivo de interesse. Outros fatores aumentam o potencial político: o alto índice de prática e o forte sentimento de minoria, aliado à natureza sectária da socialização pentecostal, fazem dessa comunidade um reservatório político relativamente fácil de atingir.» (p. 21)
} 
mudanças demográficas e religiosas, bem como às características do sistema político brasileiro, teria aberto espaço

«para a fusão de elementos dos papéis do político clientelista e do coronel, na figura do deputado 'irmão', inserindo a 'base moral do parentesco e da crença' na construção de um clientelismo mais estável» (p. 220, grifo meu).

Pierucci e Prandi (1995) buscam responder se a filiação religiosa no Brasil teria alguma influência sobre o voto. Os autores se baseiam em survey do instituto Datafolha aplicado durante as eleições de 1994. O trabalho apresenta os resultados de modelos que tomam o voto em FHC e em Lula como variáveis dependentes. Pierucci e Prandi reportam que, embora haja um efeito estatisticamente significativo da religião quando tomada isoladamente, a filiação religiosa deveria ser observada juntamente com outras variáveis.

Outro trabalho importante foi o de Fernandes (1998), que, pela primeira vez, deu uma dimensão mais acurada sobre como evangélicos votavam em seus candidatos. A partir de um survey aplicado a 1.332 moradores da região metropolitana do Rio de Janeiro, Fernandes apresenta dados que corroboram a ideia de um alto grau de apoio dado pelos fiéis aos candidatos de suas igrejas. Segundo o estudo, $87 \%$ dos fiéis da AD e de outras igrejas pentecostais votariam em candidatos das próprias igrejas, e $95 \%$ dos fiéis da IURD votariam em candidatos da própria IURD (Fernandes, 1998, p. 126). Há que se observar, porém, que esses percentuais se baseiam nas respostas dos entrevistados e são referentes a um período e local específicos. De todo modo, Fernandes ofereceu evidências consistentes para sustentar a hipótese de que candidatos evangélicos obteriam um alto grau de apoio dos fiéis de suas igrejas.

A compreensão do fenômeno das «candidaturas oficiais», e, de modo mais geral, da incursão evangélica nas eleições brasileiras, exigiu uma atenção maior para aquela que tem sido, do ponto de vista eleitoral, a igreja mais bem-sucedida do país: a Igreja Universal do Reino de Deus.

Mariano (2004) descreve o modus operandi e o processo de expansão da IURD. Fundada em 1977 no Rio de Janeiro por Edir Macedo, a IURD é, talvez, a mais famosa igreja neopentecostal brasileira. Seu processo de crescimento foi notável: em 1989, apenas 12 anos após a fundação, já possuía 571 locais de culto espalhados pelo país. Mariano ressalta a centralização decisória da IURD como uma das principais explicações para sua rápida expansão.

Outro trabalho a contribuir para a compreensão do funcionamento da IURD é o de Oro (2003). Segundo Oro, a IURD realiza recenseamentos de seus fiéis antes das eleições, de modo a saber com precisão o número de eleitores de que dispõe. Esses dados seriam apresentados aos bispos regionais, que, por sua vez, os encaminhariam à liderança nacional. A partir daí, a Igreja 
avaliaria quantos candidatos deve lançar em cada município ou estado. Trata-se, como aponta Mariano (2004), de uma estratégia centralizada, de âmbito nacional e coerente com a própria centralização decisória da igreja. Disso pode-se presumir que a IURD evita uma competição política intra-IURD; a estratégia adotada provavelmente busca evitar que candidatos iurdianos tenham de competir pelos mesmos votos. Os cultos seriam usados para fazer publicidade dos candidatos, e eventualmente, para apresentá-los aos fiéis ${ }^{28}$.

Os resultados da estratégia adotada pela IURD podem ser vistos no número de deputados eleitos pela Igreja entre o final da década de 1980 e início de 2000. Se, em 1986, a Igreja havia eleito um representante para o Congresso, em 2002 ela já possuía 16 representantes na Câmara dos Deputados e 19 deputados em Assembleias estaduais.

O bem-sucedido modelo de «candidaturas oficiais» da IURD foi, segundo Oro (2003), emulado por outras igrejas pentecostais, tais como a AD e a IEQ. Porém, isso não significa que tenham adotado o mesmo tipo de «pressão» ou orientação direta aos fiéis característica da IURD. No modelo iurdiano, a eleição do candidato é dependente do apoio da Igreja: o reconhecimento social e a votação decorrente se dão menos pelas qualidades pessoais dos candidatos do que pelo apoio institucional da igreja (Souza, 2009). Isso ficaria claro nos diversos casos de parlamentares que, embora tendo sido eleitos como representantes da IURD, desentenderam-se com a Igreja e foram expulsos, e, então, não mais se elegeram ${ }^{29}$. A dependência do apoio da igreja não é, porém, exclusividade da IURD.

Desde o início, a «irrupção pentecostal» na política brasileira se fez mais presente nas eleições para o legislativo do que naquelas para o executivo. Mesmo assim, estas últimas também receberam atenção acadêmica. A hipótese de um suposto «voto evangélico» nos pleitos para o executivo foi gradativamente incorporada aos estudos de comportamento eleitoral. O primeiro trabalho nessa linha foi o de Bohn (2004), que se baseou no survey do ESEB de 2002 e se focou na disputa para o executivo federal. Segundo a autora, os evangélicos foram o único grupo cuja maioria votou no candidato Anthony Garotinho (PSB), também ele evangélico. Os demais grupos votaram em sua maioria em Lula (PT). No segundo turno, todos os grupos votaram majoritariamente em Lula. Bohn afirma também que nenhum dos grupos religiosos apresenta percentuais altos ou muito diferentes de identificação partidária.

\footnotetext{
${ }^{28}$ No Brasil, a proibição de propaganda política em igrejas se deve ao Art. 37 da lei 9.504/97. A probição não se dirige especificamente a igrejas. É, antes, uma proibição de caráter abrangente e dirigida a bens cujo uso depende de cessão do poder público e/ou a bens de uso comum. Nessa segunda categoria («bens de uso comum»), entrariam locais como cinemas, lojas, centros comerciais e templos religiosos. A lei é vaga, deixando uma margem considerável de interpretação sobre o que se constituiria numa propaganda política em templo religioso. Não é claro, por exemplo, se a simples exposição de um candidato no púlpito (sem que se faça qualquer referência ao voto) seria propaganda política.

${ }^{29}$ Alguns exemplos de parlamentares ligados à IURD que se desentenderam com a Igreja e não se reelegeram são Magaly Machado, Valdeci de Paiva e Paulo Velasco, entre outros (Souza, 2009).
} 
Carreirão (2007) também se baseou no ESEB para investigar algumas variáveis relevantes na escolha dos eleitores para a eleição presidencial de 2006. É interessante ressaltar que, dentre as variáveis sócio-econômicas incluídas nos modelos que tentam explicar a intenção de voto para os candidatos, a filiação religiosa aparece como a mais relevante. Além disso, pela primeira vez nas eleições presidenciais brasileiras, «voters' religion was the most relevant variable for the voting decision for one of the candidates [Garotinho] with chances of reaching the second round» (p. 83). Vale dizer que em 1998, Garotinho, então candidato do PDT, foi eleito governador do Rio de Janeiro. Apesar de não ter obtido apoio formal das principais lideranças evangélicas, Garotinho buscou e obteve os votos dos evangélicos (Fonseca, 2008).

Em 2010, a eleição presidencial foi nitidamente marcada pela discussão de temas religiosos (Pierucci, 2011), e, em parte por isso, em parte pela presença da candidatura de Marina Silva (PV), evangélica da AD, houve mais uma vez apoio evangélico a uma candidata claramente identificada como evangélica. Se, para Cervellini, Giani e Pavanelli (2010), eleitores evangélicos teriam se afastado da candidatura de Dilma no fim do primeiro turno devido à polêmica sobre o aborto, para Peixoto e Rennó (2011) há uma probabilidade grande de eleitores evangélicos não terem votado em Dilma no primeiro turno, tendo optado pela candidatura de Marina Silva.

Esses exemplos revelam que, em eleições para o executivo, candidatos evangélicos podem gozar de certo apoio por parte de eleitores evangélicos. Não obstante, deve-se reconhecer que a filiação religiosa se tornou uma variável importante nos modelos que analisam o comportamento eleitoral no Brasil, e isso se deve muito provavelmente ao crescimento do eleitorado evangélico. No entanto, se levadas em conta as eleições brasileiras desde a redemocratização até 2014, os exemplos citados acima são poucos e não configuram nenhuma tendência aparente. Além disso, ainda que houvesse mais casos de candidatos evangélicos bemsucedidos em eleições para o executivo, a própria lógica das disputas em eleições majoritárias no Brasil torna o «elemento» evangélico menos importante do que o seria numa eleição em sistema de representação proporcional, como é o caso nas eleições para vereadores, deputados estaduais e federais. A disputa majoritária, isto é, a disputa pela maioria dos votos num distrito - seja ele municipal, estadual ou nacional -, exige logicamente do candidato evangélico um apelo a eleitores de outras denominações religiosas e não religiosas, de vez que a população evangélica, embora expressiva, não constitui (em termos nacionais) nem um terço da população total e está dividida em centenas de denominações diferentes. Em contrapartida, a disputa em eleições proporcionais, sobretudo em distritos de alta magnitude, como ocorre nas eleições brasileiras para Câmaras Municipais, Assembleias Legislativas e Câmara dos Deputados, permite ao candidato evangélico se focar prioritariamente no eleitorado evangélico. 
O sucesso evangélico nas eleições para o legislativo, comparativamente maior do que o sucesso para o executivo, foi enfatizado por Machado (2005). Em seu trabalho, a autora investigou a denominação de todos os 60 candidatos evangélicos para a Câmara dos Deputados que disputaram cadeiras pelo estado do RJ nas eleições de 2002. Conseguiu identificar 36 casos, sendo a grande maioria candidatos representantes de igrejas pentecostais. Machado faz referências às «práticas clientelistas» das igrejas evangélicas, assumindo de modo implícito que os fiéis evangélicos, particularmente pentecostais, comporiam a «clientela política» dos candidatos dessas igrejas.

O trabalho de Baptista (2007) busca responder à pergunta sobre qual seria a prática política dos pentecostais em suas igrejas e no campo político-partidário brasileiro. Um dos autores mais críticos aos pentecostais, o diagnóstico de Baptista sobre a entrada deles na política é bastante negativo. $\mathrm{O}$ trecho a seguir é ilustrativo:

«os partidos e grupos ansiosos por conquistar o poder perceberam há duas ou três décadas a facilidade com que lideranças pentecostais eram seduzidas à cooptação, através de acordos fisiológicos e clientelistas. Perceberam, também, o potencial eleitoral que resultava dessas adesões, em termos de quantidade de votos, porque as congregações pentecostais, em geral, se comportavam como currais eleitorais.» (2007, p. 16)

Para Baptista, as campanhas de «candidatos oficiais» pentecostais exigiriam poucos gastos financeiros devido ao fato de essas igrejas «funcionarem como currais eleitorais» (p. 352). A participação pentecostal na política não significaria a representação política de um segmento social até então marginalizado, mas apenas a «reprodução contemporânea da política de currais eleitorais para beneficiar cúpulas das igrejas» (p. 442).

Borges (2009) investigou o fenômeno da dispersão dos políticos evangélicos em diversos partidos. A questão subjacente é a de por que, a despeito de terem a mesma crença, esses políticos não constituíram um partido político. Borges ressalta que a separação entre a Igreja Católica e o Estado brasileiro, bem como o pluralismo da sociedade brasileira, permitiriam em princípio a existência de um «partido evangélico». A parte empírica do trabalho se baseia em survey de 2002 aplicado a 770 deputados estaduais de 22 unidades federativas brasileiras da legislatura 1999-02. Borges não encontrou distinções significativas entre os deputados com diferente base eleitoral religiosa. Não haveria traços que singularizassem os deputados de base eleitoral evangélica, por exemplo, em relação aos de base eleitoral católica ${ }^{30}$.

\footnotetext{
${ }^{30}$ Vale notar que, embora o sistema partidário brasileiro não conte com nenhum partido formalmente evangélico, o Partido Republicano Brasileiro (PRB), criado em 2005, é considerado por muitos analistas como «braço político» da IURD. Tal associação, no entanto, não é clara, e tanto o partido quanto a igreja a negam. A IURD possui deputados em outros partidos, mas a maioria está concentrada no PRB. Vale notar também que, em 2015, começou a ser criado
} 
Mariano e Oro (2011) ressaltam que candidatos e partidos políticos não podem mais ignorar o crescimento evangélico, o que explicaria o esforço de políticos para obter apoio de líderes evangélicos, na expectativa de serem apoiados pelos «rebanhos» desses líderes. É pela relação entre políticos e igrejas pentecostais que os autores falam de uma instrumentalização recíproca entre religião e política no Brasil. No entanto, embora ressaltem tal instrumentalização, Mariano e Oro afirmam que a suposta obediência dos fiéis pentecostais a seus candidatos é frequentemente superestimada, e defendem que o ativismo político pentecostal não significa necessariamente um problema para a democracia. Pelo contrário, ele poderia encorajar valores e práticas democráticas ao incorporar uma considerável parcela da população ao jogo político.

O trabalho de Machado e Burity (2014) se baseia em entrevistas feitas com 58 lideranças pentecostais - quase todas com cargo eclesiástico (pastores, missionários, bispos, etc.) - que, em 2011-2012, atuavam em capitais brasileiras. Os autores defendem que, nas últimas décadas,

«o Pentecostalismo teria se tornado uma religião pública, e um dos fatores mais importantes nesse processo talvez tenha sido a adoção de um modelo corporativo de representação política, com o lançamento de candidaturas oficiais por parte da IURD. Esse tipo de iniciativa ampliou a força política do grupo e, consequentemente, acirrou as disputas no interior do campo evangélico fazendo com que outras igrejas criassem espaços de debate, socialização e organização das iniciativas no campo da política eleitoral. A Assembleia de Deus a maior denominação pentecostal -, a Igreja do Evangelho Quadrangular e outras começaram a imitar a IURD na produção de materiais, realização de reuniões de orientação para os candidatos e apresentação de suas respectivas plataformas políticas» (p. 606, grifos meus).

Os autores defendem que posições supostamente conservadoras de políticos evangélicos não devem ser necessariamente vistas como problemáticas para a democracia. Tratar-se-ia, antes, de uma dimensão agonística natural do jogo democrático. Machado e Burity afirmam também que a ideia de que exista um «projeto pentecostal» de poder é equivocada, não havendo nada no discurso das lideranças pentecostais que autorize tal conclusão. Apesar do tom assaz benigno em relação aos pentecostais, os autores não deixam de estabelecer a já conhecida relação entre pentecostais e clientelismo, afirmando que a participação pentecostal na política, «mais do que ajudar na superação, tem contribuído para a reprodução das lógicas patrimonialista, personalista, autoritária e clientelística presentes na cultura política brasileira.» (p. 622)

o Partido Republicano Cristão (PRC), explicitamente ligado à Assembleia de Deus. Enquanto o presente trabalho é escrito, o partido busca coletar assinaturas para sua formalização. Esses dois exemplos devem ser levados em conta na consideração sobre a existência de partidos evangélicos no Brasil. 
Boas (2014) investiga o efeito de títulos religiosos nos «nomes de urna» dos candidatos brasileiros. Para tanto, trabalha com um experimento aplicado por meio de Facebook nas eleições muncipais de 2012 e baseado numa amostra de conveniência. O experimento é feito com um candidato hipotético a vereador. Algumas informações do candidato são apresentadas ao grupo de controle, e o grupo de tratamento recebe também a ocupação do candidato («pastor» ou «doutor»). Boas encontra efeitos significativos para os dois títulos testados. No entanto, o efeito é negativo para o primeiro (exceto para evangélicos, que respondem positivamente) e positivo para o segundo. A explicação sobre por que pastores evangélicos usariam o títutlo «pastor» nas eleições, mesmo tendo um efeito negativo, seria que, no sistema de representação proporcional com lista aberta, é mais fácil se eleger com uma base eleitoral menor e/ou mais definida. O título «pastor» faz com que o candidato ganhe mais votos entre evangélicos, ainda que os perca entre os outros grupos.

Embora o crescimento pentecostal tenha se dado em vários países da América Latina, no Brasil ele foi acompanhado por um crescimento igualmente notável do número de candidaturas pentecostais nas eleições. A incursão eleitoral pentecostal se iniciou na Constituinte, mas não se limitou a ela. Por conta disso, o esforço acadêmico voltado para a compreensão da relação entre pentecostais e política no Brasil se focou predominantemente na dimensão eleitoral do fenômeno. Essa é uma diferença entre a maior parte dos estudos pós-1990 focados no caso brasileiro e a literatura sobre as consequências do crescimento pentecostal para a América Latina. Mas não é a única. Dos anos 1990 em diante, os estudos focados no Brasil serão marcados por diferentes recursos metodológicos, bem como por uma diferença de áreas de procedência (ao lado da sociologia da religião, nota-se uma presença maior da ciência política, em particular da área de comportamento eleitoral).

O segundo conjunto de trabalhos visto aqui aponta para algumas conclusões importantes e que devem ser enfatizadas. Em primeiro lugar, não é possível tratar os evangélicos na política nem mesmo os pentecostais - como um grupo homogêneo. Não há, seja na arena eleitoral, seja na arena legislativa, um bloco evangélico coeso (cf. Pierucci, 1989; Mariano e Pierucci, 1992; Freston, 1993; Oro, 2003; Burity, 2005; Borges, 2009). No campo legislativo, a unidade dos evangélicos se restringe à oposição ao aborto e ao casamento homossexual, e, mesmo nesses casos, não se trata de uma unidade resultante de algum tipo de ação concertada, mas sim das convicções morais dos deputados individuais (Fonseca, 2008). Desse modo, seria teoricamente inadequada uma análise do desempenho político-eleitoral evangélico que os tratasse en bloc.

Em segundo lugar, a incursão eleitoral evangélica tem se dado sobretudo nas eleições para o poder legislativo. Embora haja casos de evangélicos relativamente bem-sucedidos concorrendo para cargos executivos, conquistando até mesmo a prefeitura do Rio de Janeiro (vide Marcelo Crivella em 2016) e o terceiro lugar na disputa pela presidência da República 
(vide Garotinho em 2002, e Marina Silva em 2010 e 2014), esse desempenho se mostra muito aquém daquele apresentado por candidatos evangélicos em disputas para o legislativo. Como foi dito, ao menos parte dessa discrepância se explicaria pelo sistema eleitoral brasileiro majoritário para as eleições para o executivo, e de representação proporcional de lista aberta para todos os legislativos, exceto o Senado.

Em terceiro lugar, e como desdobramento do ponto anterior, essa literatura descortinou que a mobilização eleitoral evangélica não se deu de forma equilibrada e dispersa entre os diferentes ramos evangélicos. Foi, ao contrário, fruto de um fenômeno específico, coordenado internamente e restrito a um grupo de igrejas. Freston (1993) foi o primeiro a observar que o sucesso eleitoral evangélico foi consequência das «candidaturas oficiais» pentecostais, fenômeno que, curiosamente, recebeu relativamente pouca atenção dos trabalhos posteriores. No entanto, a própria literatura sobre o caso brasileiro indica que é esse, em grande medida, o fenômeno responsável pela «irrupção pentecostal» nas eleições, e, em particular, nos legislativos brasileiros. Isso por si só revela que qualquer referência a uma suposta «força eleitoral» evangélica é, no melhor dos casos, uma forma imprecisa de tratar o problema. Se há uma «força eleitoral», ela reside nas «candidaturas oficiais» pentecostais. Abordarei este tema mais adiante.

O segundo conjunto de trabalhos considerados aqui, mais focados no caso brasileiro, apresenta algumas diferenças em relação àqueles voltados para a América Latina. Como já foi ressaltado, o segundo grupo apresenta certas diferenças metodológicas em relação ao primeiro, utilizando-se de pesquisa histórica, entrevistas, surveys e experimento. As questões que orientam os trabalhos do segundo grupo são também, de modo geral, mais específicas do que as do primeiro. A referência ao «impacto» do crescimento protestante nos países latino-americanos foi suplantada por perguntas mais delimitadas sobre a mobilização eleitoral protestante, mas sobretudo pentecostal, que toma lugar no Brasil pós-1988. Nesse sentido, pode-se dizer que o segundo grupo se preocupa mais com a compreensão empírica de como se dá o fenômeno do que com seu impacto futuro ou a longo prazo.

Porém, a despeito dessas diferenças, há uma semelhança relativa entre os dois grupos, ou, por outra, certa continuidade entre eles. Os trabalhos de ambos os grupos se apoiam no caráter clientelista ou fisiológico da política pentecostal. Nos trabalhos voltados para a América Latina, o clientelismo aparece como mecanismo que explicaria a reprodução, por parte das igrejas pentecostais, das formas tradicionais de dominação. Nos trabalhos voltados para o caso brasileiro, as referências ao clientelismo (ou fisiologismo) continuam aparecendo, embora, talvez, em menor grau (cf. Pierucci 1989; Freston 1993; Machado 2005; Baptista 2007; Machado e Burity 2014).

Não se trata de dizer que a caracterização da mobilização política pentecostal como clientelista esteja inteiramente equivocada ou em desacordo com a realidade. Antes de tudo, é 
forçoso reconhecer que os trabalhos fazem essa caracterização de diferentes formas. Alguns deles argumentam que pentecostais não seriam mais clientelistas do que outros grupos sociais e políticos, mas apenas tanto quanto eles. Outros ressaltam que a atuação clientelista das igrejas pentecostais seria uma decorrência natural da cultura política latino-americana, ela mesma caracterizada por relações clientelistas (cf. Martin 1990; Smith 1994). É claro que, em alguma medida, a afirmação de que as igrejas pentecostais compartilham da cultura política da sociedade na qual estão inseridas é verdadeira. Porém, parece uma afirmação trivial. Se não apenas as igrejas pentecostais, mas todos os grupos sociais e políticos que compõem a sociedade brasileira atuam de forma clientelista; se, como diz Mariz (1994), até mesmo o Estado brasileiro é clientelista, então é de se perguntar qual o ganho analítico no uso do conceito.

Outros trabalhos ainda usam o clientelismo como argumento para fundamentar o juízo de que o crescimento pentecostal seria potencialmente nocivo à democracia (cf. d'Epinay 1970; Bastian 1994; Chesnut 1997; Gaskill 1997). Nesse caso, o clientelismo é usado sem uma análise teórica, empírica ou conceitual mais aprofundada, e não fica claro como ele poderia ser operacionalizado e testado no contexto das relações entre igrejas pentecostais e seus representantes $^{31}$. Muitas vezes, apenas se assume que os eleitores de representantes dessas igrejas compõem a clientela política delas. O clientelismo é igualado a pork barrel politics, ou políticas paroquiais. O conceito é a tal ponto esgarçado que acaba abarcando quase qualquer tipo de relação política entre representante e representado.

Do ponto de vista teórico-normativo, parece pouco contestável o argumento de que os pentecostais, como qualquer grupo social, podem e devem lutar por participação e representação política. De modo semelhante, parece pouco questionável que eleitores pentecostais busquem eleger como seus representantes candidatos que compartilhem de sua identidade e valores. $\mathrm{O}$ ponto que deveria ser investigado então é se, na atuação política pentecostal, há qualquer coisa de diferente da atuação de outros grupos. Para ser plausível, a tese de que a mobilização pentecostal se baseia em práticas clientelistas e é, portanto, nociva à democracia exigiria uma série de investigações empíricas. Seria necessário demonstrar que tais práticas ocorrem com este grupo e não ocorrem com os outros (ou que ocorrem mais com eles do que com outros). Porém, essas investigações não foram feitas ${ }^{32}$. Afirmações sobre o uso de práticas clientelistas costumam

\footnotetext{
31 Para uma discussão conceitual sobre clientelismo, ver Hagopian (2009), Kitschelt e Wilkinson (2007), Stokes (2007) e Kitschelt (2000). Apesar de alguma variação, esses trabalhos costumam definir o clientelismo político como a provisão de benefícios ou bens materiais em troca de apoio eleitoral (em geral, votos).

32 A única exceção é Rudi (2006). A autora tenta estabelecer uma narrativa que remonta (mas é anterior) à implantação da República e que segue até a democracia pós-1988. Essa narrativa mostraria uma continuidade nas práticas de favorecimento político ou apropriação privada da coisa pública, que culminaria no clientelismo eleitoral atual por parte de deputados evangélicos. Porém, ao comparar projetos de lei de autoria de deputados estaduais evangélicos e não-evangélicos, Rudi chega à conclusão de que não há diferença significativa entre eles. Segundo ela, «entre os [candidatos] evangélicos, a ideia de clientelismo nos moldes apresentados na revisão bibliográfica e em
} 
ser mais fáceis de fazer do que de provar. Seria necessário, também, investigar a relação entre clientelismo - ou, talvez, políticas paroquiais - e democracia. No caso do clientelismo, embora haja evidências de que sua prática seja deletéria para a democracia, isso não significa que democracias não possam conviver (e convivam) com práticas clientelistas (cf. Avelino 1994). Guardadas as devidas proporções, o mesmo vale para políticas paroquiais ${ }^{33}$.

Como frisei acima, embora identifique a atuação política pentecostal a práticas clientelistas, a literatura não é clara sobre como ou de que modo essa associação se daria. Vou assumir, então, que a alegação de que políticos pentecostais se comportam de modo clientelista equivale a dizer que esses políticos produziriam políticas paroquiais, ou, no mínimo, mais políticas paroquiais do que os demais políticos. O tipo de política que produziriam seria o que a literatura da ciência política americana chama de pork barrel (Mayhew, 1974), isto é, políticas de benefícios localizados e custos difusos feitas por parlamentares ávidos por garantir sua reeleição.

Cabe observar que a hipótese de que a atuação dos parlamentares brasileiros seria primeiramente voltada para a produção de políticas paroquiais é comum na literatura sobre a política brasileira. $\mathrm{O}$ sistema eleitoral brasileiro produziria campanhas centradas nos candidatos, que, somadas à fraqueza dos partidos políticos e à descentralização resultante do arranjo federativo, criariam incentivos para que os parlamentares produzissem leis voltadas a seus redutos eleitorais (cf. Mainwaring, 1999; Ames, 2001). No entanto, estudos posteriores apresentaram evidências de que, ao menos no plano federal, leis de tipo paroquial, isto é, de benefícios localizados, constituem a minoria das leis produzidas pelo Congresso (e.g. Ricci, 2000). Os defensores da hipótese do «comportamento paroquial» dos deputados brasileiros desconsideraram o impacto que as regras internas dos legislativos podem ter sobre a atuação dos políticos, bem como o efeito produzido por distritos de magnitude elevada, que incentivariam os deputados a criar leis de abrangência nacional ou setorial. Mesmo assim, na próxima seção, investigarei a hipótese de que as leis produzidas por parlamentares pentecostais seriam distintas, isto é, mais paroquiais do que as dos demais parlamentares.

comparação com o (...) grupo não evangélico, se perde em meio à sua atuação enquanto grupo. Entre os eleitores evangélicos não há troca por benefícios materiais especificamente (...). Não cabe [entre candidato evangélico e eleitores] a ideia clientelista de beneficiar sua base, [pois] não há uma região específica que o elegeu.» (p. 102)

${ }^{33}$ A relação que Freston (1993) tenta estabelecer entre o político pentecostal e o «coronel» também é difícil de ser sustentada. Como lembra Carvalho (1997), o conceito de coronelismo apresentado por Nunes Leal (1948), a despeito de se ter difundido amplamente, possuía um sentido específico: o coronelismo seria um sistema, uma estrutura político-social; e, além disso, seria datado historicamente, com um período de vida mais ou menos coincidente ao da Primeira República. 


\section{Seriam os projetos de lei dos deputados pentecostais paroquiais?}

Será que deputados pentecostais criam mais projetos de lei paroquiais do que seus pares católicos, espíritas ou não religiosos? Em caso positivo, essa seria uma evidência para corroborar o juízo de que pentecostais criam políticas que beneficiam suas clientelas locais em detrimento do interesse público. De modo a testar essa conjectura, escolhi a Assembleia Legislativa do estado de São Paulo (doravante ALESP) para fazer uma análise dos projetos de lei dos deputados pentecostais. Em comparação com outras Assembleias e com a Câmara dos Deputados, uma proporção considerável de leis produzidas pela ALESP é de tipo paroquial (cf. Tomio e Ricci, 2012). Os testes estatísticos feitos a seguir são simples. Meu objetivo é tão-somente demonstrar a dificuldade de sustentar, em termos empíricos e conceituais, que a atuação pentecostal na política seria clientelista e, portanto, nociva à democracia brasileira.

Analiso duas legislaturas da ALESP, a de 1999-2002 e a de 2003-2006. Para a primeira, foram eleitos seis candidatos pentecostais: Daniel Marins, Edna Macedo, Faria Jr., Gilberto Nascimento, Márcio Araújo e Milton Vieira. Para a segunda, foram eleitos dez: Adilson Barroso, Bispo Gê, Dra. Maria de Jesus, Marcelo Bueno, Milton Vieira, Pastor Bittencourt, Roberto de Jesus, Souza Santos, Wagner Salustiano e Waldir Agnello. A tabela 1 apresenta, para cada um, o percentual de votos válidos, o partido e a igreja. 
Tabela 1. Pentecostais eleitos para a Assembleia paulista

\begin{tabular}{lccc}
\hline \hline & \multicolumn{3}{c}{ Legislatura 1999-2002 } \\
& $\%$ Votos & Partido & Igreja \\
\cline { 2 - 4 } Daniel Marins & 0,41 & PPB & IEQ \\
Edna Macedo & 0,52 & PTB & IURD \\
Faria Jr. & 1,08 & PMDB & IURD \\
Gilberto Nascimento & 0,35 & PMDB & AD \\
Márcio Araújo & 0,47 & PFL & IURD \\
Pastor Milton Vieira & 0,36 & PRONA & IURD \\
& \multicolumn{3}{|c}{} \\
& \multicolumn{3}{c}{ Legislatura 2003-2006 } \\
Adilson Barroso & 0.051 & PRONA & AD \\
Bispo Gê & 0.495 & PSDB & Renascer \\
Dra. Maria de Jesus & 0.338 & PTN & IURD \\
Marcelo Bueno & 0.268 & PDT & AD \\
Milton Vieira & 0.362 & PFL & IURD \\
Pastor Bittencourt & 0.183 & PGT & AD \\
Roberto de Jesus & 0.374 & PTB & IURD \\
Souza Santos & 0.371 & PL & IURD \\
Wagner Salustiano & 0.423 & PPB & IURD \\
Waldir Agnello & 0.665 & PSB & IEQ \\
\hline \hline
\end{tabular}

Os projetos de lei do banco de dados estão classificados em quatro categorias. A primeira é a de (i) projetos administrativos, orçamentários e financeiros. São os projetos de caráter estadual, que versam sobre a administração pública, incluindo os três poderes. A segunda é a de (ii) projetos de políticas públicas. Assim como a categoria anterior, têm caráter estadual ou regional, mas se referem a políticas públicas específicas (saúde, meio ambiente, agricultura, entre outras). A terceira é a de (iii) projetos paroquiais. São aqueles que beneficiam de modo direto e efetivo um ou poucos municípios. Exemplos comuns são projetos que alienam imóveis do estado a um município, transformam um município em estância turística, criam regiões administrativas e fazem declarações de utilidade pública ${ }^{34}$. Por fim, a quarta é a de (iv) projetos simbólicos. São

\footnotetext{
${ }^{34}$ É importante ressaltar que os projetos enquadrados nesta categoria não beneficiam necessariamente apenas um município. Dentro dela estão, por exemplo, projetos que criam faculdades ou cursos em determinados municípios. É plausível supor que tais projetos beneficiarão outras cidades do estado (no caso de faculdades, os habitantes dos municípios do entorno também serão beneficiados). Porém, o que define seu enquadramento nesta categoria é o fato de beneficiar diretamente um ou poucos municípios específicos.
} 
aqueles cujo benefício é não apenas paroquial, senão também pouco tangível. Exemplos comuns são projetos de homenagem, denominação de ruas, viadutos e praças, e que instituem dias - dia do turismo, dia do autista, etc.

Meu interesse é verificar se deputados pentecostais produzem mais políticas paroquiais do que os demais. 'Políticas paroquiais', nesse caso, abarcam tanto a terceira quanto a quarta categorias. Vou verificar, por meio de duas regressões logísticas bivariadas, se há alguma associação entre ser pentecostal e projetos de lei paroquiais ou simbólicos. A variável dependente é uma variável binária que assume valor 1 para projetos paroquiais ou simbólicos e 0 para os demais. A variável independente também é binária e assume valor 1 quando o autor do projeto de lei é pentecostal, e 0 em qualquer outro caso. Optei por incluir na análise apenas os projetos de autoria do poder legislativo e apenas projetos de lei (PLs) e projetos de lei complementar (PLCs). Apresento abaixo dois testes diferentes. No primeiro, incluo todos os PLs e PLCs do período ( $\mathrm{N}=7.201$ ), independentemente de terem se tornado ou não lei. No segundo, incluo apenas os PLs e PLCs que viraram leis durante o mandato dos deputados $(\mathrm{N}=1.869)$.

Tabela 2. Efeito de ser pentecostal sobre projeto de lei paroquial

\begin{tabular}{lcc}
\hline \hline & Todos os projetos & Projetos que viraram lei \\
\cline { 2 - 3 } Pentecostal & $-1.177^{* * *}$ & $-1.144 * * *$ \\
& $(0.107)$ & $(0.226)$ \\
Constante & -0.126 & 1.662 \\
& $(0.025)$ & $(0.064)$ \\
\hline $\mathrm{N}$ & 7201 & 1869 \\
Pseudo R2 & 0.014 & 0.021 \\
\hline \hline
\end{tabular}

Nota: erros padrão em parênteses. *** para $\mathrm{p}<0.01$

Os resultados das regressões mostram que não há associação positiva entre ser deputado pentecostal e produzir políticas paroquiais. Pelo contrário, se há algum efeito, ele é negativo e com significância estatística. Um projeto de lei que tenha como autor um deputado pentecostal tem uma probabilidade menor de ser paroquial ou simbólico do que um cujo autor não é pentecostal. Não há dúvida de que os modelos acima são simples e não controlam por uma série de fatores que precisariam ser levados em consideração. Um dos mais óbvios exemplos é a base eleitoral do deputado, isto é, se o deputado tem base concentrada ou difusa. Mesmo que um candidato pentecostal hipotético seja eleito com votos provenientes sobretudo de eleitores evangélicos, isso não significa que esses votos estejam geograficamente concentrados. Os fiéis 
que deram voto ao candidato podem estar dispersos no território do distrito. Tal candidato poderia legislar para seu eleitorado por meio de leis que, embora tenham como alvo os evangélicos, não são leis paroquiais em sentido estrito.

No entanto, mesmo essa possibilidade também exigiria investigação mais cuidadosa. Nas duas legislaturas da ALESP analisadas, os deputados pentecostais produziram um total de 86 leis. Desse total, 17 foram projetos assinados por todos ou pela maioria dos líderes partidários, e, portanto, não são leis endereçadas a algum reduto eleitoral evangélico específico. Das 69 restantes, 26 são leis paroquiais e 22 simbólicas. Entre as paroquiais, a quase totalidade é composta por declarações de utilidade pública que, presumivelmente, dirigem-se a instituições religiosas ou para-religiosas. Entre as simbólicas, apenas nove fazem referências religiosas explícitas $^{35}$. Considerando tudo, tem-se um total aproximado de 35 leis com algum tipo de conotação religiosa explícita, seja de forma simbólica, seja por beneficiar alguma instituição religiosa. Trata-se de um conjunto minoritário do total de leis produzidas por deputados pentecostais. Não obstante, essas 35 leis foram produzidas por um grupo de 15 deputados num período de duas legislaturas, ou seja, oito anos.

É evidente que deputados pentecostais produzirão parte de suas leis visando garantir o apoio eleitoral de suas bases. Se essas bases são formadas por eleitores pentecostais, parte dessas leis provavelmente terá o objetivo de agradar eleitores pentecostais. Todavia, tal comportamento - direcionar seu esforço legislativo no sentido de maximizar sua chance de reeleição - é assumido por parte da ciência política como pressuposto explicativo geral para o comportamento de congressistas. Não parece haver aí nada que distingua os deputados pentecostais de outros deputados. Parte das leis que esse grupo produz parece ter como foco eleitores evangélicos, mas o mesmo ocorre com deputados oriundos de outros grupos sociais, que buscarão o apoio eleitoral desses mesmos grupos. Porém, como se viu anteriormente, o fato de um deputado estadual paulista ser pentecostal não apenas não aumenta a probabilidade de que ele produza leis paroquiais, como diminui tal probabilidade.

\section{Considerações finais}

Em que pesem as considerações feitas acima, o uso do clientelismo como mecanismo explicativo evidencia uma suposição importante, a saber, que políticos pentecostais receberiam, quando candidatos, grande apoio eleitoral de seus fiéis. Desde d'Epinay (1970), é comum na literatura a ideia de que políticos pentecostais poderiam contar com sólido apoio eleitoral dos seus fiéis, caracterizados como a «clientela» ou «curral eleitoral» desses políticos. A evidência de apoio eleitoral sólido ao candidato pentecostal não corrobora o argumento clientelista, mas é

\footnotetext{
${ }^{35}$ Exemplos são o PL 705/1999, que institui o dia do músico evangélico, e o PL 433/2003, que institui o dia da
} Assembleia de Deus. 
condição necessária para ele. Além disso, é necessária também para a própria caracterização das «candidaturas oficiais» pentecostais. No entanto, até hoje, poucos trabalhos apresentaram evidências para isso.

O exame da literatura sobre a relação entre crescimento pentecostal e política na América Latina e Brasil colocou em relevo a importância do fenômeno das «candidaturas oficiais» pentecostais. A despeito das evidências apresentadas por Freston (1993), a hipótese da centralidade dessas candidaturas na explicação da mobilização eleitoral pentecostal ainda depende de uma série de investigações e testes. É preciso investigar como se deu o crescimento eleitoral dos evangélicos desde a década de 1990 até hoje. Nesse sentido, vale a pena frisar que, embora alguns trabalhos reportem o número de candidatos evangélicos eleitos numa determinada eleição ou num determinado estado, tais levantamentos são sempre limitados. Não obstante, os trabalhos que buscaram mapear os candidatos evangélicos trabalharam apenas com os candidatos eleitos. Um esforço para investigar o desempenho eleitoral das igrejas evangélicas e pentecostais ganharia muito se levasse em consideração o desempenho dos candidatos eleitos em relação ao desempenho do número total de candidatos lançados. É necessário investigar a dinâmica das candidaturas evangélicas em relação ao volume total de candidaturas nas eleições para o legislativo, e estabelecer a mesma relação entre as candidaturas pentecostais e as evangélicas. No próximo capítulo, pretendo explorar de forma mais detalhada algumas dessas questões. 


\section{Capítulo 2}

\section{Evangélicos, Pentecostais e Representação Política nas Eleições para o Legislativo no Brasil (1998-2010)*}

\section{Introdução}

As eleições gerais de 1986 representaram um turning point para a mobilização eleitoral dos evangélicos no Brasil. Se, até o início da década de 1980, não mais do que uma dúzia de protestantes eram eleitos por pleito para a Câmara dos Deputados, nas eleições de 1986 nada menos do que 32 representantes evangélicos se elegeram. Desde então, o número de candidatos evangélicos eleitos vem crescendo. Porém, a despeito do crescimento, a presença evangélica no legislativo ainda está longe de espelhar a dos evangélicos na população brasileira. Mesmo sendo o caso de maior sucesso eleitoral evangélico na América Latina (Boas 2014), os evangélicos ainda são sub-representados no parlamento brasileiro.

A sub-representação de minorias nas democracias contemporâneas é uma tema de relevo para as ciências sociais. Pesquisas recentes buscaram investigar por que certos grupos sociais não entram na polítical eleitoral, ou, quando o fazem, por que não são bem-sucedidos (e.g., Dancygier et al. 2015; Bueno e Dunning 2014; Wängnerud 2009). Uma das preocupações normativas subjacente a esses estudos é a da representação descritiva (cf. Pitkin 1967; Mansbridge 1999). Uma representação no parlamento que espelhe a constituency em questão poderia contribuir para uma melhor defesa de seus interesses, além de aumentar o sentimento de inclusão política do grupo, sinalizando que o sistema político está aberto para aquele e outros grupos sociais minoritários. Por outro lado, há argumentos que questionam a representação descritiva. A ideia de uma representação como «espelho» do corpo social poderia não produzir, por si só, resultados desejáveis para grupos minoritários (cf. Young 2002).

A sub-representação dos evangélicos na política brasileira não parece provocar na opinião pública a mesma preocupação provocada pela de outros grupos sociais minoritários. $\mathrm{Na}$ realidade, a posição da mídia e da academia em relação ao ativismo eleitoral dos evangélicos é, em geral, negativa. A cobertura midiática durante as eleições sugere que as igrejas pentecostais do país teriam considerável força política, sendo detentoras de «currais eleitorais» e/ou

\footnotetext{
* O presente capítulo foi submetido para publicação na Revista Brasileira de Ciências Sociais.
} 
caracterizando o voto dos fiéis como «votos de cabresto» ${ }^{36}$. A suposta força política dos evangélicos costuma ser avaliada como um perigo, seja por se constituir numa ameaça ao Estado laico, seja porque o próprio voto de eleitores evangélicos em candidatos evangélicos representaria um falseamento das verdadeiras preferências dos primeiros ${ }^{37}$.

A atenção acadêmica para as consequências políticas do crescimento pentecostal na América Latina se acentuou a partir do final dos anos 1960. Os estudos sobre o tema ressaltaram o modo como as igrejas pentecostais ingressariam na política adotando práticas clientelistas e potencialmente nocivas à democracia (cf. D’Epinay 1970; Bastian 1994; Chesnut 1997; Gaskill 1997). O apoio eleitoral dos fiéis seria um meio eficaz para a eleição de líderes pentecostais, que, uma vez no poder, beneficiariam suas igrejas com políticas paroquiais. $\mathrm{O}$ argumento aventado se baseia na suposição implícita de que o «rebanho eleitoral» das igrejas ofereceria um alto grau de apoio eleitoral a seus líderes.

A mobilização eleitoral das igrejas pentecostais na América Latina foi particularmente forte no caso do Brasil e ganhou atenção acadêmica crescente a partir dos anos 1990 (e.g., Mariano e Pierucci 1992; Freston 1993; Pierucci e Prandi 1995; Fernandes 1998; Oro 2003; Borges 2009; Mariano e Oro 2011; Machado e Burity 2014). O crescimento da população evangélica, aliado à abertura do «mercado religioso» brasileiro e às especificidades do sistema eleitoral (representação proporcional de lista aberta com distritos de alta magnitude) foram algumas das principais causas apontadas para o aumento do número de representantes evangélicos na política brasileira. A literatura sobre o tema indica também que o crescimento político evangélico pós-Constituinte se deu sobretudo graças à mobilização eleitoral das igrejas pentecostais. A partir da década de 1980, essas igrejas passaram a adotar um modelo de representação corporativa, engajando-se na disputa eleitoral com «candidatos oficiais» $\mathrm{e}$ concorrendo a vagas nos legislativos municipais, estaduais e federal. O caso mais conhecido é provavelmente o da Igreja Universal, que, ao longo da década de 1990, elegeu dezenas de bispos e pastores para a Câmara dos Deputados, Assembleias estaduais e Câmaras municipais.

\footnotetext{
${ }^{36}$ Ver, por exemplo: «Presidente da CNBB diz que igrejas não são 'currais eleitorais'», Folha de S. Paulo, 29/08/14; «'Apóstolos', 'Bispos' e 'Pastores': os novos coronéis dos currais eleitorais», T1 Notícias, 12/08/14; «Igreja Católica não tem curral eleitoral», $O$ Estado de S. Paulo, 07/09/14; «Bancada evangélica terá sete vereadores na Câmara Municipal do Rio, $14 \%$ do total», $i G, 11 / 10 / 12$; «Voto não pode ser condicionado à fé evangélica, defendem igrejas históricas», Congresso em Foco, 03/10/14; «Partidos tentam evitar veto de igrejas em SP», Folha de S. Paulo, 16/01/12.

${ }^{37}$ Frei Betto, por exemplo, em entrevista ao jornal Folha de S. Paulo, afirma que a laicização do Estado seria ameaçada por uma bancada evangélica que deseja «confessionalizar a política», ensejando «[u]ma forma de fundamentalismo tupiniquim, altamente perigoso». O crescimento da bancada evangélica, longe de ser produto legítimo da própria composição religiosa da população brasileira, seria tributado a pessoas que «perdem totalmente a consciência (...) e se tornam cordeirinhos de qualquer um que queira manipulá-las». As igrejas evangélicas transformariam «seus fiéis em cordeirinhos, que, ameaçados pela teologia do medo, acabam seguindo a voz do pastor naquilo que ele dita» («'Temo que a presidente Dilma renuncie', diz frei Betto», Folha de S. Paulo, 09/08/15).
} 
Embora haja evidências de que a representação corporativa pentecostal tenha sido responsável pelo aumento da representação evangélica no poder legislativo brasileiro (cf. Freston 1993), poucos esforços foram feitos para investigar a dimensão da representação corporativa pentecostal sobre a representação evangélica dos anos 1990 em diante. Não obstante, nenhum esforço empírico sistemático foi feito para perscrutar a mobilização político-eleitoral evangélica com base não apenas nos políticos eleitos, senão no total de candidatos evangélicos de um conjunto de eleições. O foco exclusivo nos políticos eleitos, em detrimento dos demais candidatos evangélicos, é problemático por razões óbvias. A literatura sobre recrutamento e carreiras políticas enfatiza a importância de analisar a representação levando em conta também os competidores não eleitos (e.g., Perissinotto e Miríade 2009; Norris e Lovenduski 1995). Afirmações sobre a «força» eleitoral dos evangélicos ${ }^{38}$, seja enquanto grupo, seja em relação às igrejas, correm o risco de se prestar a sérios equívocos por ignorar o quadro geral das candidaturas evangélicas.

O presente trabalho busca contribuir nessa direção. A partir de um novo banco de dados de candidaturas evangélicas, a conter informações sobre a igreja e a votação de todos os candidatos evangélicos para a Câmara dos Deputados e 27 Assembleias Legislativas nas eleições de 1998 a 2014, pretendo contribuir para preencher as lacunas apontadas no parágrafo anterior. Em particular, o trabalho visa responder às seguintes perguntas: qual é o desempenho dos candidatos evangélicos nas eleições para o legislativo no Brasil? Seriam as candidaturas corporativas pentecostais responsáveis pela representação dos evangélicos nos legislativos brasileiros? Teriam as igrejas pentecostais um alto grau de sucesso eleitoral?

O capítulo está organizado da seguinte forma. Na seção seguinte, apresento uma discussão conceitual e metodológica sobre o «candidato oficial» pentecostal. Meu objetivo é oferecer uma definição analítica mais precisa do fenômeno, bem como apresentar as igrejas que adotam o modelo de representação corporativa pentecostal. Na seção 3, apresento dados sobre a variação relativa e total das candidaturas evangélicas, variação das candidaturas por estado e sua distribuição partidária. Na seção 4, o foco recai sobre o desempenho da representação corporativa pentecostal e sobre as igrejas que o adotam. A última seção sumariza os achados, apresenta as conclusões e sugere caminhos para futuras pesquisas.

\section{Candidatos evangélicos e pentecostais: discussão conceitual e metodológica}

Até as eleições de 1986, a maior parte dos candidatos protestantes eleitos para a Câmara dos Deputados provinha de igrejas históricas, sobretudo da Batista e da Presbiteriana. A presença de representantes das igrejas pentecostais era quase inexpressiva. Ainda em 1982, foram eleitos

\footnotetext{
${ }^{38}$ Ver, por exemplo, «A força dos evangélicos» (Revista Época, 05/09/14); e «Vinde a mim os eleitores: a força da bancada evangélica no Congresso» (Revista Veja, 23/03/13).
} 
apenas 12 evangélicos para a Câmara, sendo sete ligados à Igreja Batista e um à Assembleia de Deus. Esse panorama mudou fortemente nas eleições de 1986 para o Congresso Constituinte, quando se elegeram 32 representantes evangélicos. Dessa vez, a despeito da presença de dez deputados batistas, bem como de representantes de outras igrejas históricas, nada menos do que 13 parlamentares eleitos eram assembleianos, além de dois ligados à Igreja do Evangelho Quadrangular e um à Igreja Universal do Reino de Deus. Tratou-se, pois, de uma mudança de perfil parlamentar, mas também de expressiva mudança numérica (cf. Pierucci 1989, Freston 1993).

A explicação fundamental para essa mudança foi a adoção, por parte das igrejas pentecostais, de um modelo corporativo de representação política. Nesse modelo, as igrejas adotariam «candidaturas oficiais»e as promoveriam a seus fiéis. Freston (1993) identificou o fenômeno no apoio oficial de igrejas pentecostais a candidaturas para os legislativos estaduais e federal. A adoção do modelo corporativo estaria restrita a três igrejas: Assembleia de Deus (AD), Igreja do Evangelho Quadrangular (IEQ) e Igreja Universal do Reino de Deus (IURD) (cf. Freston 1993, p. 197). Freston deixa implícito que os «candidatos oficiais» seriam representantes orgânicos das próprias igrejas e que existiriam apenas nas igrejas pentecostais.

Minha caracterização das «candidaturas oficiais» pentecostais parte de Freston, mas não se limita a ele. Ao contrário de boa parte da literatura sobre crescimento protestante e política latino-americana, mais preocupada com as consequências dessa relação para o próprio campo protestante (e.g., Willems 1967, Martin 1990) do que para a política, minha preocupação reside sobretudo nas consequências políticas e eleitorais do fenômeno - o que não significa que a análise com tal enfoque não possa contribuir para uma compreensão sociológica mais geral sobre o pentecostalismo brasileiro. Entendo a representação corporativa pentecostal como um recurso institucional que certas igrejas oferecem a seus candidatos, e o «candidato oficial» pentecostal como um tipo ideal weberiano ${ }^{39}$. A representação corporativa é uma prática das igrejas pentecostais, e não das igrejas protestantes históricas ou de missão.

As transformações no campo protestante e pentecostal no Brasil, aliadas ao sistema político brasileiro pós-1988 (em particular ao sistema de representação proporcional de lista aberta e à alta magnitude dos distritos brasileiros), à pluralização da sociedade civil e ao fim do monopólio católico do mercado religioso ${ }^{40}$, contribuíram para que se produzisse o fenômeno de candidatos ao poder legislativo apoiados oficialmente por igrejas pentecostais. O perfil social dos membros das igrejas, o processo de socialização sectária, a confiança depositada nos pastores e

\footnotetext{
${ }^{39} \mathrm{O}$ tipo ideal weberiano se baseia na acentuação de certas características de um dado fenômeno (Weber 2001).

${ }^{40}$ Cumpre notar que embora, em número declarado de fiéis, a Igreja Católica tenha permanecido hegemônica no Brasil até o início da segunda metade do século XX, a situação no debate público brasileiro foi, desde o fim do século XIX, muito diferente, como o atesta, por exemplo, o conflito entre clero católico, liberais e maçons.
} 
líderes religiosos, tudo isso contribuiria para que, supostamente, esses candidatos recebessem um apoio sólido das igrejas.

Enquanto tipo ideal, o «candidato oficial» pentecostal é o representante de uma igreja. A relação entre ambos supõe que a igreja reconhece o candidato e o promove a seus fiéis para que votem nele. Esse reconhecimento não precisa ser publicizado para a sociedade civil. Na verdade, a maior parte das igrejas que adotam o modelo de representação corporativa não publiciza, para fora de suas comunidades, o apoio a seus candidatos. $\mathrm{O}$ apoio se dá apenas no interior da igreja ou da comunidade. Embora alguns candidatos usem «pistas religiosas» para atrair o eleitorado evangélico, são poucos os casos em que essas «pistas» incluem uma referência explícita a uma igreja. De modo geral, o questionamento a uma igreja feito por um pesquisador externo sobre quais candidatos são apoiados por ela não será bem recebido ${ }^{41}$. No entanto, a principal característica do «candidato oficial» é o fato de ser apoiado pela igreja. Essa definição exclui do conceito todos aqueles candidatos que professam determinada fé evangélica, mas que não são apoiados por suas igrejas. Eles seriam candidatos evangélicos, mas não «candidatos oficiais». A distinção abaixo ilustra o que foi dito.

Suponha-se dois candidatos, A e B, cada um vinculado a uma igreja evangélica, A' e B', respectivamente. $\mathrm{O}$ candidato $\mathrm{A}$ é apenas um fiel da igreja $\mathrm{A}^{\prime}$, isto é, comunga publicamente da doutrina professada pela igreja A'. Porém, a igreja A' não está necessariamente comprometida com a candidatura de $\mathrm{A}$. $\mathrm{O}$ candidato $\mathrm{B}$, por sua vez, não apenas comunga publicamente da doutrina professada pela igreja B', mas é também o candidato escolhido por B' para representála, e, portanto, será apoiado por ela. Do que foi dito acima se depreende que, neste exemplo, apenas o candidato B seria um «candidato oficial», e não o candidato A. O interesse no «candidato oficial» não reside em seu grau de religiosidade, mas na relação de apoio estabelecida entre ele e a igreja, relação que supõe a promoção, por parte da igreja, do candidato para os fiéis dela.

Um terceiro caso possível de relação entre igreja e candidato que merece ser explicitado é o de uma igreja C' que apoia publicamente um candidato $C$, sem que $C$ seja um fiel ou membro da igreja C'. Seria essa a situação de muitas igrejas nas eleições para o executivo: promovem publicamente um candidato, que, porém, não provém dos quadros da igreja. No caso de candidatos para o legislativo, que é o que nos interessa aqui, a grande maioria das candidaturas evangélicas se enquadra nos exemplos A ou B. A seguir, dou exemplos para os três casos.

Em 2014, a candidata Benedita da Silva (PT-RJ) foi reeleita deputada federal para seu quarto mandato na Câmara. Antes disso, fora eleita vereadora pela cidade do Rio de Janeiro e

${ }^{41}$ Das grandes igrejas pentecostais brasileiras adeptas do modelo de representação corporativa, a única que respondeu minhas perguntas sobre quais candidatos apoiou nas últimas eleições foi a IEQ. Aproveito para agradecer às assessoras do deputado Jefferson Campos (PSD) e do vereador Carlos Evaristo (PSD), ambos da IEQ, pela ajuda na obtenção de informações para esta pesquisa. 
foi, também, a primeira mulher negra eleita para o Senado. Evangélica, Benedita já foi ligada à Assembleia de Deus, mas hoje é presbiteriana. Além de ser atualmente vinculada a uma igreja que não apresenta «candidaturas oficiais», a carreira política de Benedita sempre dependeu pouco de recursos institucionais de igrejas, sendo, antes, baseada em sua militância partidária (PT) e na participação em movimentos sociais. Assim, Benedita seria um exemplo do caso A.

Jefferson Campos (PSD-SP) é pastor da Igreja do Evangelho Quadrangular e, em 2014, foi reeleito para seu quarto mandato como deputado federal. Antes, havia sido vereador pela cidade de Sorocaba (SP) por dois mandatos. Campos possui um vínculo formal com a IEQ, igreja que adota o modelo de representação corporativa. Assim, Campos é um exemplo do caso B.

Em 2014, o candidato Alceu Bueno (PSL) disputou uma vaga para deputado federal no Mato Grosso do Sul. Bueno era vereador de Campo Grande. O candidato era apoiado pela Igreja Mundial do Poder de Deus, tendo gravado vídeo com Valdemiro Santiago no qual o líder da IMPD pedia votos a Bueno. Porém, em abril de 2015, Bueno sofreu denúncia por suposto envolvimento com uma rede de prostituição infantil. Representantes da igreja reconheceram que ela de fato apoiou o candidato, mas que Bueno não seria membro da igreja ${ }^{42}$. Assim, Bueno seria um exemplo do caso $\mathrm{C}$.

Tabela 3. Tipos de relação entre candidato e igreja.

\begin{tabular}{ccc}
\hline \hline Tipo & Descrição & Exemplo \\
\hline $\mathrm{A} \rightarrow \mathrm{A}^{\prime}$ & Candidato da igreja, mas não oficial. & Benedita da Silva (PT-RJ) \\
$\mathrm{B} \rightarrow \mathrm{B}^{\prime}$ & Candidato oficial da igreja. & Jefferson Campos (PSD-SP) \\
$\mathrm{C} \rightarrow \mathrm{C}^{\prime}$ & Candidato oficial, mas não pertencente à igreja. & Alceu Bueno (PSL-MS) \\
\hline \hline
\end{tabular}

Fonte: elaboração do autor.

$\mathrm{O}$ «candidato oficial» pentecostal é, pois, aquele cuja candidatura é promovida aos fiéis de uma igreja e cujo desempenho eleitoral depende em considerável medida do apoio dessa igreja. Com isso, excluo do conceito casos hipotéticos em que um candidato é apoiado por uma igreja sem que seja membro dela e, não obstante, sem que dependa fortemente desse apoio para sua viabilidade eleitoral.

\footnotetext{
${ }^{42} \mathrm{O}$ escândalo envolvendo Bueno foi noticiado por jornais e sites de internet. Um exemplo: 'Pastor diz que vereador envolvido em escândalo não é membro da igreja', Midiamax, 21/04/15. Endereço: http://www.midiamax.com.br/politica/256257-pastor-vereador-envolvido-escandalo-nao-membro-igreja.html (acessado pela última vez em 18/12/15).
} 
Se, no plano conceitual, essa definição é pouco problemática, na investigação empírica a situação é mais complicada. É possível pensar num continuum de graus de apoio de uma igreja a um candidato e seria difícil estabelecer empiricamente qual o grau necessário para que um candidato seja enquadrado no conceito. Dou um exemplo. Um pastor da Igreja Batista Vida Plena, de São Bernardo do Campo (SP), relatou-me em entrevista que sua igreja apoia candidatos a vereador. Quando perguntei como é o apoio de sua igreja ao candidato, ele respondeu que a igreja (i.e., o pastor) apresenta o candidato aos fiéis e diz que ele é da igreja, mas que ninguém tem obrigação de votar nele só porque é da igreja. «Nós não damos o púlpito para que ele faça propaganda e não há apoio financeiro ou logístico» ${ }^{43}$. Essa situação, mesmo que pudesse ser caracterizada como uma «candidatura oficial», estaria numa posição do continuum muito distante daquela da IURD, cujo apoio a um candidato pode implicar em campanha política no púlpito e em certa pressão da igreja sobre os fiéis.

O problema de ter de definir um grau mínimo de apoio das igrejas aos candidatos pode ser contornado por meio de uma mudança de estratégia. Meu interesse reside em identificar e separar as «candidaturas oficiais» pentecostais das demais candidaturas evangélicas, para, depois, compará-las. Trata-se, pois, de dividir as candidaturas evangélicas em dois grupos. Seguindo a literatura, definirei como «candidatos oficiais» aqueles representantes das principais igrejas: Assembleia de Deus (AD); Igreja do Evangelho Quadrangular (IEQ); Igreja Universal (IURD); e, além das três usadas por Freston (1993), mais três: Igreja Internacional da Graça de Deus (IIGD); Igreja Mundial do Poder de Deus (IMPD); e Igreja Maranata. Embora possuam diferenças entre si, as seis igrejas adotam o modelo de representação corporativa.

A AD chegou ao Brasil em 1911 e é a segunda mais antiga igreja pentecostal do país, atrás apenas da Congregação Cristã, fundada em 1910. A AD foi fundada no estado do Pará, por meio dos missionários suecos Gunnar Vingren e Daniel Berg, vindos dos EUA. Sua penetração foi tão rápida que, em 1940, já estava presente em todos os estados brasileiros (Rolim 1980). É a maior igreja pentecostal do Brasil. Segundo Borges Junior (2010), o órgão da AD responsável pela organização política é a Convenção Geral (CGADB). Porém, as ADs locais atuam sem ligação administrativa a uma instituição nacional. A ligação nacional entre as igrejas é feita por meio dos pastores, filiados a convenções estaduais, que, por sua vez, vinculam-se a uma convenção nacional. A Convenção Geral, porém, não tem poder deliberativo sobre as igrejas (idem, pp. 60-61). Além disso, é importante frisar que há outras convenções nacionais da AD independentes da CGADB. As mais conhecidas são provavelmente a Convenção Nacional das Assembleias de Deus no Brasil (CONAMAD), ou Ministério Madureira, e a Assembleia de Deus

\footnotetext{
${ }^{43}$ Entrevista concedida ao autor em 17/05/15.
} 
Vitória em Cristo, do pastor Silas Malafaia. O nome «Assembleia de Deus» foi dado em 1918 e faz referência à Assembly of God americana. Porém, não há ligação institucional entre elas.

A Church of the Foursquare Gospel foi fundada nos EUA em 1923 por Aimee McPherson e chegou ao Brasil em 1951 pelos missionários Harold Williams e Jesus Ramos. Em 1953, Williams a nomeou como Igreja da Cruzada e, em 1955, ela se estruturou como Igreja do Evangelho Quadrangular (Santos, 2002). Até 1987, a matriz americana manteve o direito de nomear o presidente da igreja brasileira. Porém, o crescimento da IEQ no Brasil fez com que, em 1988, a liderança deixasse de ser indicada pela «igreja mãe». Ao contrário da $\mathrm{AD}$, de caráter descentralizado, a IEQ tem a estrutura de um governo episcopal. Há um Conselho Nacional eleito a cada quatro anos, mas também Conselhos Estaduais e Locais.

Talvez a mais famosa igreja pentecostal do Brasil, a IURD foi fundada em 1977 no Rio de Janeiro por Edir Macedo. Desde então, apresentou um crescimento notável, tendo, já em 1990, chegado a todos os estados do território brasileiro. Mariano (2004) e Oro (2003) relacionam sua rápida expansão à estrutura centralizada da IURD, o que tornaria seu processo decisório e administrativo mais dinâmico e facilitaria seus investimentos. A Igreja possui considerável influência midiática, controlando uma rede nacional de rádios AM e FM, a Rede Aleluia, além da emissora Record de TV. Além de ser a mais famosa, a Universal é também a igreja pentecostal brasileira mais associada a sucesso político e eleitoral.

É interessante ressaltar que duas das igrejas abordadas aqui, a IIGD e a IMPD, foram fundadas por dissidentes da Universal. A IIGD foi fundada em 1980 por Romildo Ribeiro Soares (mais conhecido como R. R. Soares) na cidade do Rio de Janeiro. Conta com considerável estrutura midiática e se baseia em grande medida no televangelismo. Segundo Mariano (1999), possui sede administrativa menos profissional do que a IURD, da qual Soares se separou. A despeito das semelhanças entre as duas igrejas, a abrangência geográfica da IIGD é muito menor do que a da IURD, concentrando-se sobretudo no sudeste. A IMPD, por sua vez, foi fundada em Sorocaba (SP), em 1998, por Valdemiro Santiago. Assim como Soares, Santiago também fez parte da IURD, mas acabou se desligando e fundou a própria igreja. Em 2014, a IMPD possuía mais de 4 mil templos espalhados pelo Brasil e no exterior ${ }^{44}$.

Por fim, a Igreja Maranata nasceu em Vila Velha (ES), em 1968. Embora aparente ter estrutura menos centrada num líder do que as outras, seu primeiro presidente foi o engenheiro Manuel de Passos Barros, quem dá o nome à fundação homônima ligada à igreja. Assim como a

\footnotetext{
${ }^{44}$ Informação disponível no site oficial da igreja: http://www.impd.org.br/portal/index.php?link=institucional (acessado pela última vez em 17/12/15).
} 
IIGD e a IMPD, a Maranata «exporta» templos: segundo o site, a igreja teria mais de 50 templos fora do Brasil ${ }^{45}$.

Como se vê na Figura 3, há uma grande diferença no tamanho das seis igrejas. A AD é não apenas a maior igreja pentecostal, mas a maior igreja evangélica do Brasil em número de fiéis, sendo responsável por $29,1 \%$ dos evangélicos brasileiros. A segunda (entre as seis) é a IURD, com 4,4\% dos evangélicos, acompanhada de perto pela IEQ, com 4,3\%. A IIGD, a IMPD e a Maranata vêm depois, tendo cada uma $0,8 \%$ da população evangélica do país. No entanto, a relação entre número de fiéis e «força eleitoral» está longe de ser direta, como se verá adiante.

FIGURA 3. Tamanho das igrejas pentecostais em relação ao total de evangélicos (2010)

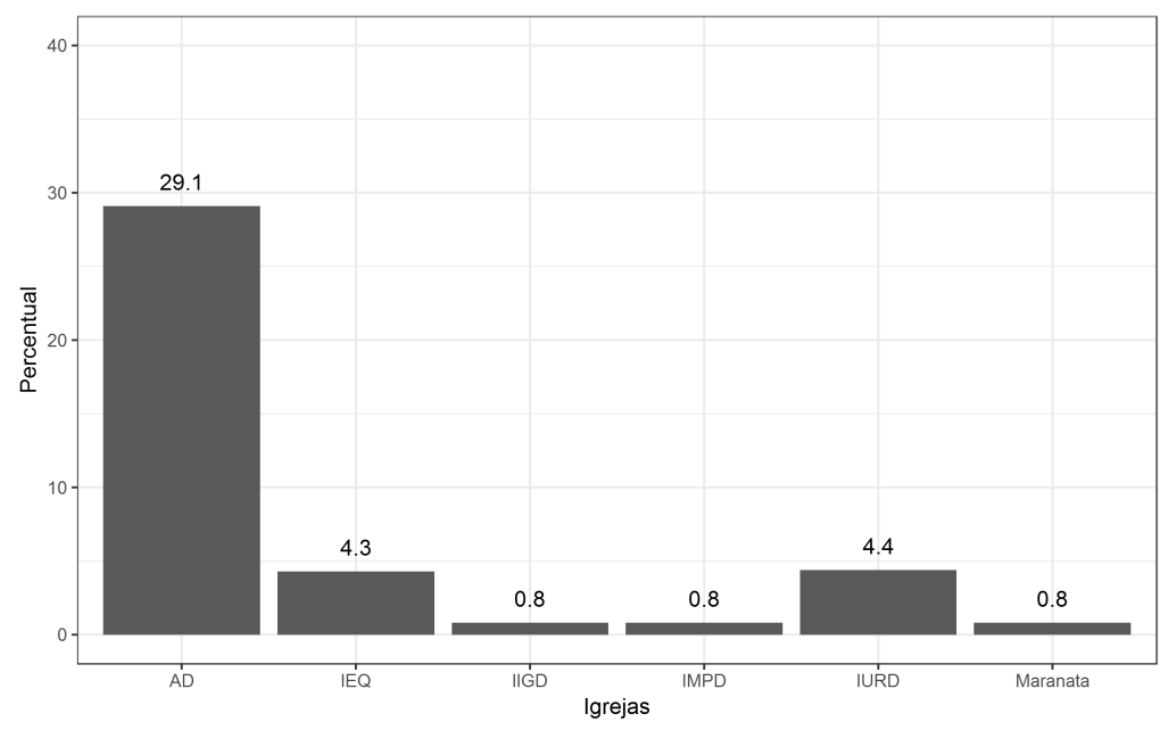

Fonte: Censo 2010

Na seção seguinte, apresentarei algumas estatísticas descritivas sobre as candidaturas evangélicas para os legislativos estaduais e federal no Brasil entre 1998 e 2014. Meu objetivo é esboçar um quadro geral dessas candidaturas, algo ainda inédito na literatura. Não obstante, pretendo comparar a relação entre as «candidaturas oficiais» pentecostais e as demais candidaturas evangélicas para averiguar qual a proporção que as primeiras ocupam em relação às segundas. Por fim, apresentarei também uma análise focada nas seis igrejas pentecostais supracitadas, com o objetivo de comparar o desempenho eleitoral de seus candidatos.

\footnotetext{
${ }^{45}$ Informação disponível no site oficial da igreja: http://www.igrejacristamaranata.org.br/?page id=2064 (acessado pela última vez em 17/12/15).
} 
O trabalho com candidatos evangélicos traz algumas dificuldades, sendo a mais óbvia a de como reconhecer ou identificar um candidato e sua igreja. Se a análise estivesse restrita aos candidatos evangélicos eleitos para os legislativos estaduais e federal, o desafio já seria difícil. O número de igrejas evangélicas no Brasil é enorme, e, ainda que não haja levantamento oficial atualizado, deve ultrapassar a casa dos milhares ${ }^{46}$. No entanto, como se viu na Figura 3 , a distribuição de fiéis por igrejas é bastante desigual: dos mais de 26 milhões de brasileiros declarados evangélicos pentecostais em 2010, quase a metade (12,3 milhões) pertencia à Assembleia de Deus (Censo 2010).

Embora muitas das igrejas promovam candidatos para seus fiéis, a promoção não costuma ser publicizada para fora dos limites da igreja. Ainda que reportagens da mídia e de órgãos de pesquisa listem periodicamente os integrantes das «bancadas evangélicas», essas listas podem conter eventuais erros e informações desatualizadas. Um exemplo são as listas das «bancadas evangélicas» feitas pelo Departamento Intersindical de Assessoria Parlamentar. O DIAP usa como critério a fé evangélica do parlamentar, relacionando não apenas os evangélicos provenientes de igrejas históricas e pentecostais, senão também alguns não vinculados a nenhuma igreja em particular ${ }^{47}$. No entanto, essas listas contêm erros e, não obstante, apresentam apenas os candidatos evangélicos eleitos. Restringir a análise aos candidatos eleitos traz um sério problema de viés de seleção. Embora muito se fale sobre o aumento da bancada evangélica, o foco sobre os eleitos ignora o possível número de candidatos evangélicos não eleitos. Assim, uma investigação sobre as candidaturas evangélicas deveria levar em conta não apenas aqueles que foram bem-sucedidos, senão também os que não o foram.

Isso, porém, traz mais dificuldades. As igrejas evangélicas não tornam públicas as relações de candidatos lançados nas eleições. Como, então, identificá-los? Desde logo, cumpre dizer que dificilmente seria factível a identificação de todos os candidatos de uma dada eleição. A impossibilidade não se deve tanto ao tamanho do esforço, que, dado o número de candidatos ao poder legislativo nas eleições brasileiras, seria considerável. O problema maior reside no fato de que há um grande número de candidatos pouco competitivos e pouco expressivos, e é praticamente impossível determinar a qual igreja estão ligados. Se, por exemplo, há uma alta probabilidade de descobrir à qual igreja pertence um candidato $\mathrm{X}$ que recebeu 10 mil votos numa

\footnotetext{
${ }^{46}$ Uma rápida incursão nos bairros periféricos da cidade de São Paulo revela o grande número de igrejas evangélicas existente. Embora as mais conhecidas - e.g., IURD e AD - sejam grandes, outras são tão pequenas que seus locais de culto são pouco discerníveis de um armazém ou de uma garagem.

47 «O DIAP classifica como integrante da bancada evangélica, além dos bispos e pastores, aquele parlamentar que professa a fé segundo a doutrina evangélica» ('Atualização da bancada evangélica: DIAP identificou 74 deputados', DIAP, 06/10/14, disponível em:

http://www.diap.org.br/index.php?option=com_content \&view=article\&id=24534:bancada-evangelicalevantamento-preliminar-do-diap-identifica-43-deputados\&catid=59:noticias\&Itemid=392; acessado pela última vez em 1/05/15).
} 
dada eleição, a probabilidade é ínfima para um candidato $\mathrm{Z}$ que tenha recebido apenas 50 votos. A seguir, descreverei a estratégia metodológica utilizada para identificar os candidatos.

Optei por uma investigação de todos os candidatos evangélicos para as Assembleias Legislativas e Câmara dos Deputados entre 1998 e $2014^{48}$. Para essas cinco eleições e para os cargos de deputado federal, distrital e estadual, concorreram um total de 85.361 candidatos. A partir das informações sobre candidaturas do TSE, montei um banco de dados original com todas as candidaturas evangélicas deferidas identificadas para as eleições do período. A identificação dos candidatos se deu de quatro maneiras principais.

(a) A primeira foi a coleta de informações sobre os candidatos na própria literatura sobre evangélicos e política no Brasil. Dada a dificuldade mencionada para a obtenção dessas informações, uma série de estudos focados em um estado, uma cidade ou uma eleição foram feitos nos quais pesquisadores buscaram investigar os candidatos evangélicos naqueles pleitos determinados. O conjunto dessas informações permite compor um primeiro quadro. Porém, a maior parte desses trabalhos dá atenção apenas aos candidatos eleitos.

(b) A segunda foi o uso de dois tipos de informações contidas nos dados do TSE: a declaração, por parte dos candidatos, de sua ocupação como «sacerdote ou membro de ordem ou seita religiosa»; e os títulos evangélicos usados nos nomes de urna (ver Tabela 4, abaixo). Na maior parte dos casos, os dois tipos se sobrepõem, ou seja: o mesmo candidato usa o título de «pastor» no nome de urna e declara sua ocupação como «sacerdote». Foram considerados evangélicos todos os candidatos que usaram em seus nomes de urna títulos de apóstolo, bispo, irmão, ministro, missionário, pastor, presbítero e reverendo. Como revela a Tabela 4, o título de «pastor» responde pela grande maioria dos títulos evangélicos, seguido pelo de «irmão». Nota-se também que, de 1998 a 2014, houve um pequeno decréscimo relativo nos títulos de «pastores» e um aumento no de «bispos» e «missionários». Em números absolutos, houve crescimento no número de candidatos com títulos evangélicos. Todos os candidatos com títulos foram checados por meio de pesquisa na internet, ainda que nem todos tenham sido confirmados ${ }^{49}$.

\footnotetext{
${ }^{48}$ Os dados do site do TSE relativos a candidaturas anteriores a 1998 estão incompletos. Segundo informações dadas por uma funcionária do Tribunal ao autor, a obtenção dessas informações precisa ser feita com os Tribunais Regionais, e, mesmo assim, não é certo que elas estejam digitalizadas. Por conta disso, optou-se por trabalhar apenas com o período 1998-2014.

${ }^{49}$ Evidentemente, foram excluídos os casos em que os nomes de urna dos candidatos contêm um título evangélico não intencional. Exemplo: José Carlos Bispo da Paz foi candidato a deputado federal pelo PSB em 2006 e adotou o nome de urna «Bispo da Paz». Casos como esse não foram computados pela razão óbvia de que seu nome de urna não é um título, e sim seu próprio sobrenome.
} 
Tabela 4. Títulos evangélicos dos candidatos para a Câmara e Assembleias (\%).

\begin{tabular}{lccccc}
\hline \hline & 1998 & 2002 & 2006 & 2010 & 2014 \\
\hline Apóstolo & 0.0 & 0.0 & 0.3 & 1.3 & 3.1 \\
Bispo & 2.2 & 9.4 & 6.7 & 5.9 & 5.1 \\
Irmão & 19.0 & 19.8 & 25.6 & 20.5 & 23.0 \\
Ministro & 0.0 & 0.7 & 0.0 & 0.0 & 0.0 \\
Missionário & 2.2 & 1.4 & 3.2 & 8.3 & 6.9 \\
Pastor & 75.2 & 67.6 & 62.9 & 62.0 & 61.2 \\
Presbítero & 0.0 & 0.7 & 0.6 & 1.0 & 0.3 \\
Reverendo & 1.5 & 0.4 & 0.6 & 1.0 & 0.5 \\
Total (N) & $100(137)$ & $100(278)$ & $100(313)$ & $100(303)$ & $100(392)$ \\
\hline \hline
\end{tabular}

Fonte: elaboração própria a partir de dados do TSE.

Nota: os percentuais se referem ao total de títulos evangélicos daquela eleição. Exemplo: em 2002, do total de 278 candidatos que usaram títulos evangélicos, 19,8\% usaram o título de «irmão».

(c) A terceira foi o contato direto com igrejas evangélicas. Esse modo de identificação acabou se revelando o menos promissor. A maior parte das igrejas protestantes históricas não possui «candidatos oficiais», nem necessariamente um registro de candidatos próximos a elas ou, pelo menos, não um registro aberto para pesquisadores não ligados a elas. Assim, tornou-se mais produtivo se aproximar de fiéis leigos para saber deles se e quais candidatos os fiéis daquela igreja apoiavam do que buscar tal informação com a cúpula da igreja. Mesmo assim, foram relativamente poucos os candidatos identificados deste modo. No que se refere às igrejas pentecostais, a disposição para oferecer informações a um pesquisador universitário foi pequena. Políticos e assessores ligados à $\mathrm{AD}$ e IURD, por exemplo, recusaram-se a oferecer alguma informação (ainda que a recusa não tenha sido explícita ou taxativa). A exceção, nesse caso, foi a IEQ, a única entre as grandes igrejas pentecostais brasileiras a colaborar com a pesquisa.

(d) Por fim, para cada estado procurei informações sobre candidatos evangélicos nos sítios na internet dos principais jornais, fossem eles de circulação nacional ou regional. Matérias detalhando disputas político-eleitorais entre candidatos evangélicos costumam fazer referências às suas igrejas. Essas informações permitem buscas mais minuciosas não apenas sobre a relação entre aquele candidato e a igreja, mas também sobre outros candidatos apoiados por aquela igreja.

Tal foi a estratégia adotada para a identificação dos candidatos evangélicos no período analisado. Ressalto que, a despeito do esforço de pesquisa de pouco mais de um ano dedicado à identificação dos candidatos evangélicos, os dados apresentados aqui podem não ser completos. É possível que alguns candidatos não tenham sido identificados. Essa possibilidade diz respeito sobretudo a eventuais candidatos evangélicos pouco competitivos e que não publicizam sua 
adesão religiosa. Embora reconheça essa possível limitação, o conjunto das quatro estratégias descritas acima permite um razoável grau de confiança na validade dos dados. Além disso, como se verá adiante, a observação dos dados revela padrões que dificilmente seriam explicáveis caso os dados estivessem muito incompletos.

Conforme aludido acima, embora os candidatos tenham sido identificados, há um subconjunto para o qual não foi possível identificar a igreja (ver Figura 4). O número de candidatos evangélicos sem igreja identificada variou de acordo com o pleito, constituindo-se em menos de 39\% dos candidatos evangélicos de 1998 e em pouco mais de 53\% dos de 2014. De modo geral, o número de candidatos evangélicos aumenta a cada eleição, e a tendência é que isso aumente também o número daqueles sem igreja identificada.

A análise dos dados revela que a existência de um contingente de candidatos evangélicos sem igreja identificada não é um grande problema. Há uma correlação clara e forte entre a probabilidade de identificação da igreja e o número de votos. Os histogramas da Figura 5, dispostos por eleição, apresentam no eixo horizontal a votação dos candidatos sem igreja identificada. Percebe-se que a grande maioria teve votações pouco expressivas, enquadrando-se na categoria cuja identificação é praticamente inviável. São candidatos que receberam muito poucos votos. Neste trabalho, minha preocupação reside sobretudo em (i) identificar os candidatos evangélicos e (ii) as igrejas dos candidatos oriundos de igrejas pentecostais. Sendo o apoio da igreja um recurso institucional que oferece ao candidato pentecostal um contingente de votos, espera-se teoricamente que, quanto menor o número de votos de um candidato evangélico qualquer, menor a probabilidade de ele ser um «candidato oficial» pentecostal. Assim, parece seguro afirmar que é baixa a probabilidade de que existam candidatos de igrejas pentecostais entre aqueles sem igreja identificada. 
FIGURA 4. Número de candidatos evangélicos sem igreja identificada

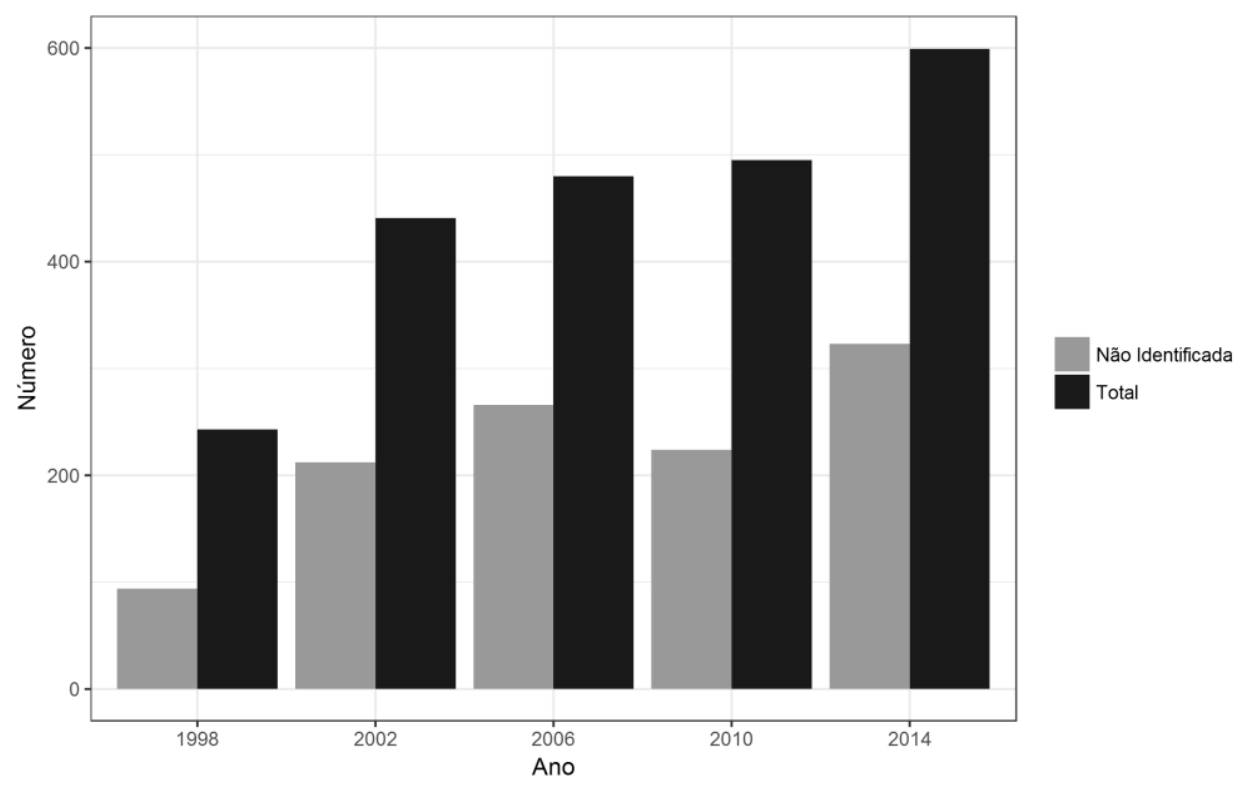

FIGURA 5. Votações de candidatos evangélicos sem igreja identificada
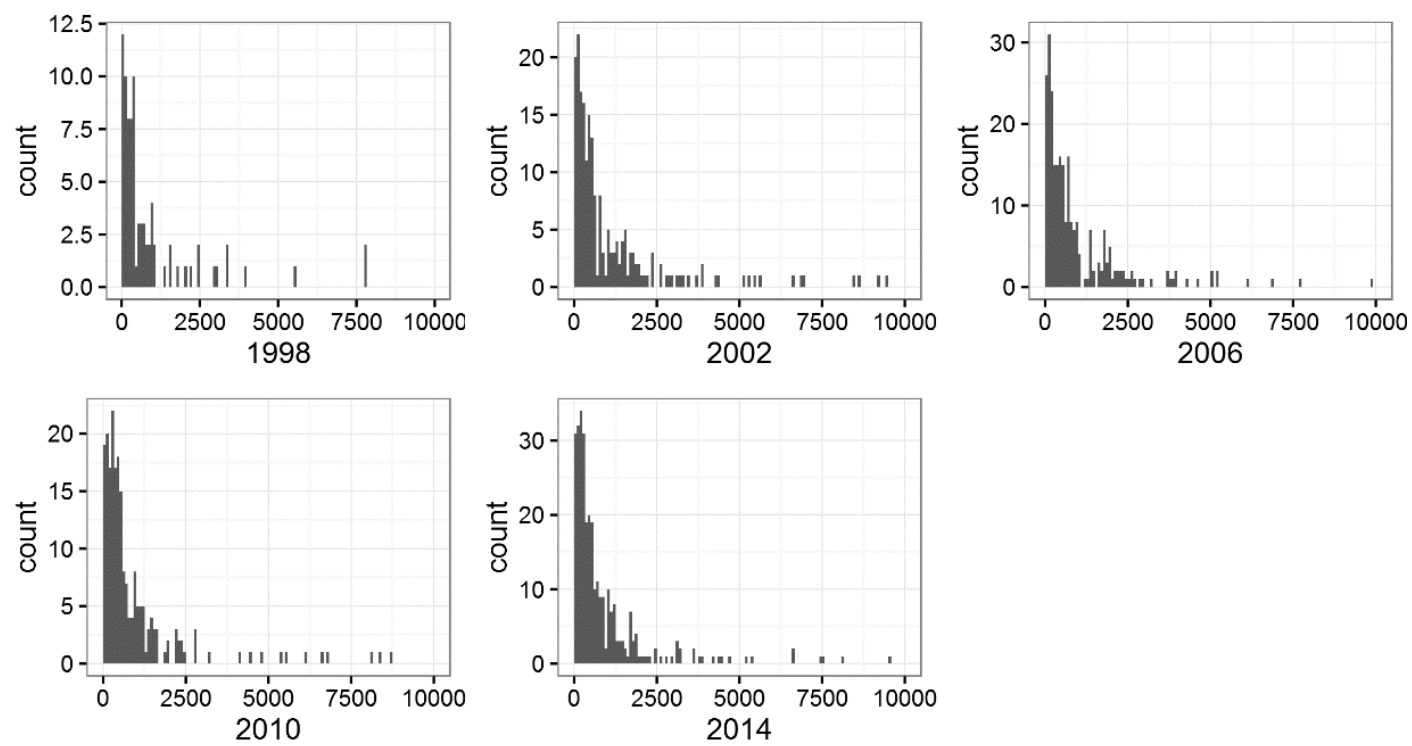

Fonte: Banco de dados de candidaturas evangélicas. 
Há, porém, uma última dificuldade a ser explicitada. Argumentei que entendo o «candidato oficial» pentecostal como um tipo ideal, e que, dada a dificuldade de estabelecer uma linha demarcatória para o que seria considerado apoio oficial de uma igreja e o que não o seria, optei por seguir Freston (1993) e assumir que certas igrejas pentecostais constituem o fenômeno da «candidatura oficial» (as igrejas são AD, IEQ e IURD, às quais acrescentei IIGD, IMPD e Maranata). Ocorre que, para investigar o fenômeno do apoio das igrejas pentecostais a seus candidatos, seria preciso distinguir, evidentemente, os candidatos de fato apoiados pela igreja daqueles que, muito embora ligados de alguma forma à igreja, não foram, na eleição em questão, oficialmente apoiados por ela.

Tal dificuldade praticamente inexiste no caso da IURD, pois ela não permite que outros candidatos (que não os «oficiais») disputem os votos de seus fiéis. Via de regra, todo candidato apoiado pela IURD é um «candidato oficial» da igreja. A situação tampouco é problemática nos cados da IIGD, IMPD e Maranata, pelo simples fato de apoiarem um número muito reduzido de candidatos e por não possuírem uma estrutura capilarizada nacional de templos e igrejas. $\mathrm{O}$ problema começa a aparecer no caso da IEQ. Schoenfelder e Paz (2006), por exemplo, relatam o caso da IEQ gaúcha, que, nas eleições de 2006, lançou dois candidatos a deputado federal, porém só um com apoio oficial da Igreja. Se, no caso da IEQ, a escala da dificuldade é ainda pequena, ela se torna maior com a $\mathrm{AD}$, a igreja a lançar o maior número de candidatos nas eleições brasileiras desde 2006.

Para este problema, não existe saída fácil. Se estudos qualitativos podem investigar com minúcias o tipo de apoio que uma igreja dá a seu candidato no âmbito local, e discernir quais candidatos foram oficialmente apoiados daqueles que, muito embora pertencentes à igreja, não receberam apoio oficial, tal investigação seria impraticável num exame quantitativo como o presente trabalho. Minha saída foi, assim, identificar os candidatos «ligados» às igrejas, ainda que, em muitos casos, não saiba precisamente se a ligação implicou em apoio oficial ou não. Estritamente falando, estou assumindo que candidatos ligados a igrejas pentecostais podem ser uma proxy de «candidatos oficiais» pentecostais.

\section{Um quadro geral das candidaturas evangélicas para o legislativo}

A primeira questão a se investigar diz respeito à variação do número de candidaturas evangélicas para a Câmara dos Deputados e Assembleias Legislativas. Entre 1998 e 2014, o número absoluto dessas candidaturas aumentou. Em 1998, 76 candidatos evangélicos disputaram vagas para o legislativo federal e 167 para os estaduais. Em 2014, esses números mais do que dobraram, chegando a 207 candidatos evangélicos para a Câmara e 392 para as Assembleias. Tal aumento em termos absolutos seria esperado, dado que a população evangélica também 
aumentou no país. A questão, então, é saber como se deu a variação relativa, isto é, o número de candidaturas evangélicas sobre o número total de candidaturas.

FIGURA 6. Candidatos evangélicos para a Câmara e Assembleias
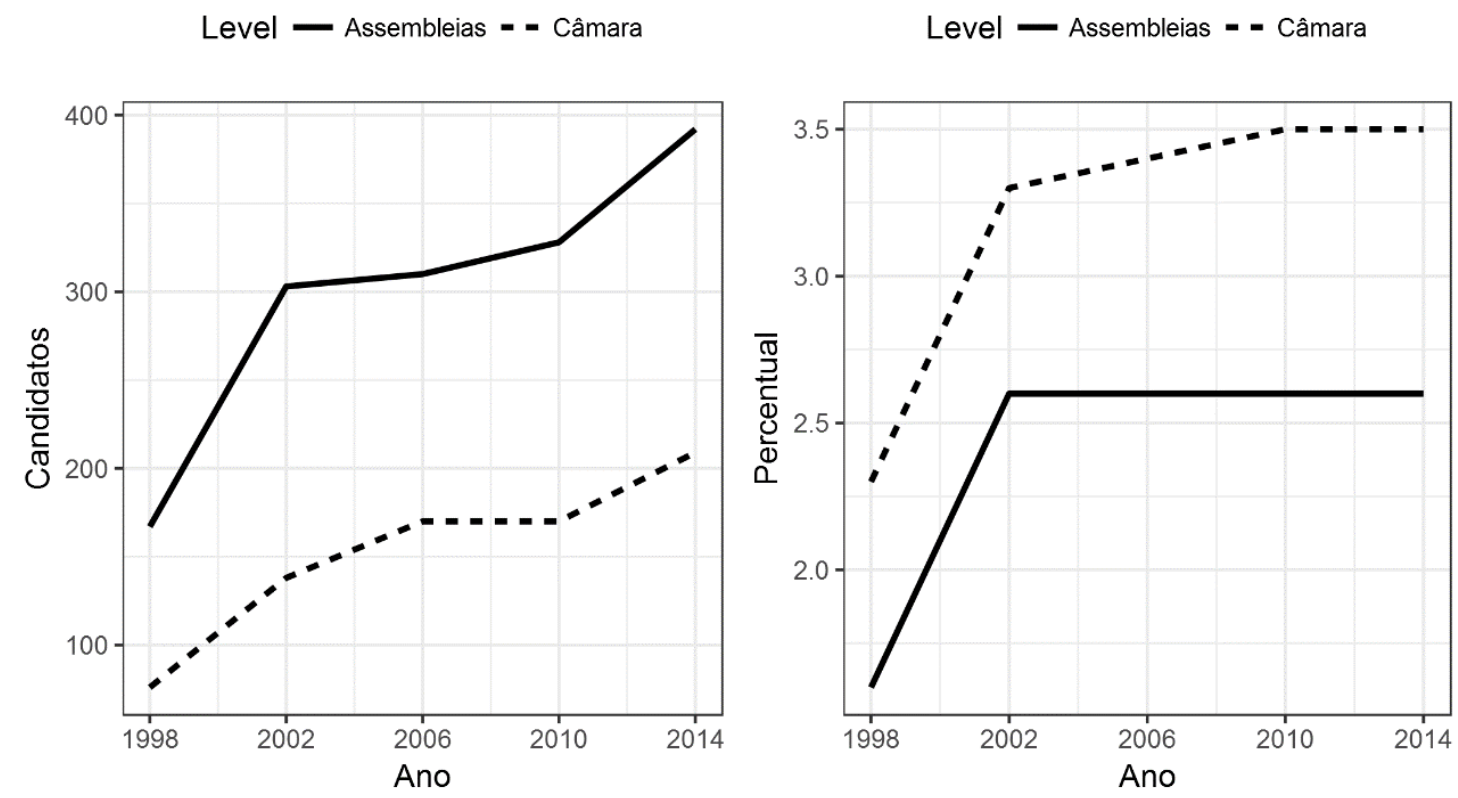

Fonte: Banco de dados de candidaturas evangélicas.

Nesse caso, também é possível identificar um aumento. Em 1998, 2,3\% do total dos candidatos a deputado federal eram evangélicos. Em 2014, esse percentual chegou a 3,5\%. Porém, nota-se que, depois do aumento entre 1998 e 2002, as candidaturas evangélicas para a Câmara permaneceram relativamente estáveis. Entre 2002 e 2014, o número relativo de candidaturas evangélicas federais teve uma variação ínfima, de aproximadamente $0,2 \%$. A situação é muito semelhante no caso dos estados. Entre 1998 e 2002, houve um aumento no número relativo de candidatos evangélicos, que passou de 1,6\% para 2,6\%; no entanto, esse número permaneceu praticamente constante de 2002 até 2014. Isso significa que, do ponto de vista da oferta de candidaturas, os evangélicos enquanto grupo populacional são fortemente subrepresentados. Seria necessário que o percentual de candidaturas evangélicas crescesse (e não se mantivesse estável), e que o fizesse de forma acentuada, para que começasse a se aproximar do percentual correspondente de evangélicos na população brasileira. Assim, no que se refere às candidaturas, afirmações sobre a «força» ou «ascensão» dos evangélicos devem no mínimo ser questionadas. 
Mesmo que se possa objetar que os números encontrados estão subestimados, e que alguns candidatos de fé evangélica podem não ter sido incorporados ao banco de dados, ainda assim seria preciso observar que a dificuldade de identificação tende a ser maior quanto mais distante temporalmente for a eleição. É mais fácil identificar os candidatos evangélicos das eleições de 2014 do que das de 1998, por exemplo. Isso significa que, mesmo que os números estivessem subestimados, dificilmente esse viés alteraria a tendência geral apresentada aqui. Ou seja: é mais provável que candidatos evangélicos de eleições mais antigas tenham sido ignorados do que candidatos de eleições recentes. Isso não altera o padrão encontrado; antes, reforça-o. As evidências apresentadas na Figura 6, que mostram que a proporção de candidatos evangélicos é menor do que a proporção de evangélicos na população, é consistente com estudos de carreiras políticas que enfatizam a oferta de candidatos para explicar a sub-representação de grupos minoritários (cf. Norris e Lovenduski 1995). Limitações de recursos, tais como tempo e dinheiro, poderiam diminuir severamente o número de evangélicos que buscam disputar um lugar como candidatos nos partidos brasileiros.

O segundo aspecto a se investigar é a variação no número de evangélicos eleitos para os legislativos federal e estadual. No caso do nível estadual, trata-se das 26 Assembleias estaduais mais a Câmara Legislativa do Distrito Federal. A Câmara dos Deputados brasileira possui 513 cadeiras, e os 27 legislativos estaduais somados, 1.059. A figura 7, abaixo, apresenta os dados. Ao contrário do número de candidaturas, que, em termos absolutos, manteve-se em crescimento tanto para o legislativo federal quanto para os estaduais, o número de evangélicos eleitos oscilou no período em questão. É verdade que a variação total foi positiva. Em 1998, 29 evangélicos foram eleitos para a Câmara, e 46 o foram para as Assembleias. Em 2014, os números para Câmara e Assembleias chegaram a 67 e 75, respectivamente. No entanto, a despeito do aumento considerável, é necessário destacar, primeiro, a queda ocorrida em 2006, e segundo, o crescimento registrado em 2010. Ambas as tendências se fizeram notar tanto no nível federal quanto no estadual. Sobre o crescimento de 2010, de 35 para 65 deputados federais, e de 50 para 59 estaduais, vale dizer que, no caso federal, foi maior até mesmo do que aquele registrado nas eleições de 1986. Isso não impediu, porém, que a população evangélica se mantivesse subrepresentada nos legislativos. 
FIGURA 7. Candidatos evangélicos eleitos para a Câmara e Assembleias

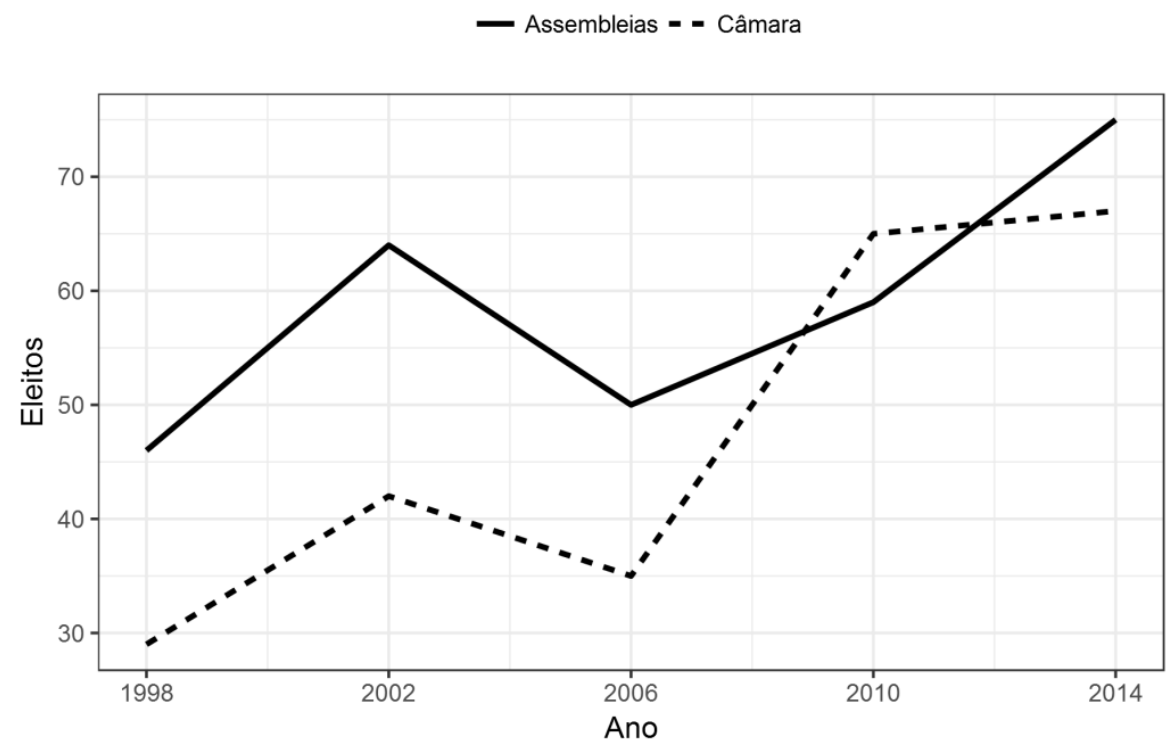

Fonte: Banco de dados de candidaturas evangélicas.

Alguns pesquisadores aventaram a possibilidade de que escândalos de corrupção ocorridos na década de 2000, envolvendo uma série de parlamentares evangélicos, teriam impactado negativamente o sucesso eleitoral do grupo (e.g., Machado e Burity 2014, Mariano e Oro 2011). Três desses escândalos são dignos de nota: o chamado «mensalão»; o escândalo dos «sanguessugas»; e o «mensalão do DEM» ${ }^{50}$. Tendo como estopim matéria da revista Veja de 2005 sobre esquema de compra de votos no Congresso, o episódio do «mensalão» teve, entre vários políticos envolvidos, o deputado Carlos Rodrigues (PL-RJ), bispo da IURD e um dos seus mais importantes articuladores políticos ${ }^{51}$. Em 2006, veio à tona o escândalo dos «sanguessugas», esquema de superfaturamento de compra de ambulâncias. Rodrigues foi acusado de ser um dos beneficiados do esquema. Segundo Souza (2009), o episódio chamou a atenção pelo fato de supostamente ter envolvido uma dezena de parlamentares ligados à AD e outros 14 ligados à IURD. Não obstante, no final de 2009 ganhou destaque na mídia o chamado escândalo do «mensalão do DEM», ocorrido no Distrito Federal e que também envolveu

\footnotetext{
50 'Bancada evangélica cai para metade no Congresso'. Portal G1, 12/10/06. (http://g1.globo.com/Noticias/Politica/0,,AA1308577-5601,00-

BANCADA+EVANGELICA+CAI+PARA+METADE+NO+CONGRESSO.html). Acessado pela última vez em $18 / 12 / 15$.

${ }^{51}$ Em novembro de 2012, o Supremo Tribunal Federal condenou Rodrigues por corrupção passiva e lavagem de dinheiro.
} 
políticos evangélicos. O episódio ficou marcado por conta de um vídeo com imagens do deputado estadual Júnior Brunelli (PSC), da Igreja Catedral da Benção, e outros recebendo propina e, em seguida, fazendo uma oração ${ }^{52}$. Embora não haja evidências suficientes para estabelecer uma relação entre os casos de corrupção e o desempenho eleitoral dos candidatos evangélicos, vale observar que os dois casos de maior repercussão (o «mensalão» e o escândalo dos «sanguessugas») ocorreram justamente em 2006, ano de queda no número de representantes evangélicos. A hipótese de conexão entre o envolvimento com corrupção e a queda na representação evangélica será retomada mais à frente, quando detalharei o desempenho eleitoral das principais igrejas pentecostais brasileiras.

A Figura 8, abaixo, apresenta as candidaturas evangélicas em números absolutos e por estado, separando o número total de candidaturas (primeiro gráfico) e o número de eleitos (segundo). Algumas coisas chamam a atenção. Rio de Janeiro e São Paulo são os estados com o maior número de candidatos evangélicos. Em seguida, mas bem abaixo, vêm Minas Gerais, Distrito Federal, Espírito Santo, Bahia e Goiás. Embora seja o estado mais populoso do país, São Paulo só ultrapassou o Rio em número de candidatos evangélicos em 2010; até aquele ano, os fluminenses lideravam com folga.

De acordo com o Censo Brasileiro de 2010, em termos absolutos, os estados com as maiores populações evangélicas são, do maior para o menor, São Paulo, Rio, Minas, Bahia, Paraná e Pará. Isso revela que a oferta de candidaturas evangélicas, embora tenha alguma relação com o tamanho das populações evangélicas estaduais, não é determinada por elas. Tome-se o exemplo de RJ e SP: Em 2014, Rio e São Paulo apresentaram 69 e 82 candidaturas, respectivamente. Esses números não traduzem o fato de que a população evangélica total de São Paulo ( 9,9 milhões) é mais do que o dobro da do Rio ( 4,6 milhões). O mesmo valeria para o fato de o Distrito Federal, por exemplo, apresentar uma oferta maior de candidatos evangélicos do que o estado do Paraná, muito embora a população evangélica paranaense ( 2,3 milhões) seja mais de três vezes superior à do DF ( 690 mil). A explicação para a variação na oferta de candidaturas deve residir, pois, ao menos em parte, na distribuição das diferentes igrejas pelos estados, bem como nas diferenças organizacionais entre as igrejas. A distribuição das candidaturas evangélicas por eleição e por estado não revela evidências claras de uma relação entre o suposto envolvimento com escândalos de corrupção e a oferta de candidaturas evangélicas. Na maior parte dos estados, não houve queda de candidaturas em 2006. Por outro lado, vários estados registraram uma queda entre 2006 e 2010, sendo a do Rio a mais significativa.

\footnotetext{
52 'Imagens do suposto esquema de mesada a deputados têm até oração'. G1, 30/11/09 (http://g1.globo.com/Noticias/Politica/0,,MUL1397543-5601,00.html). Acessado pela última vez em 18/12/15.
} 
FIGURA 8. Candidatos evangélicos por estado (total e eleitos)
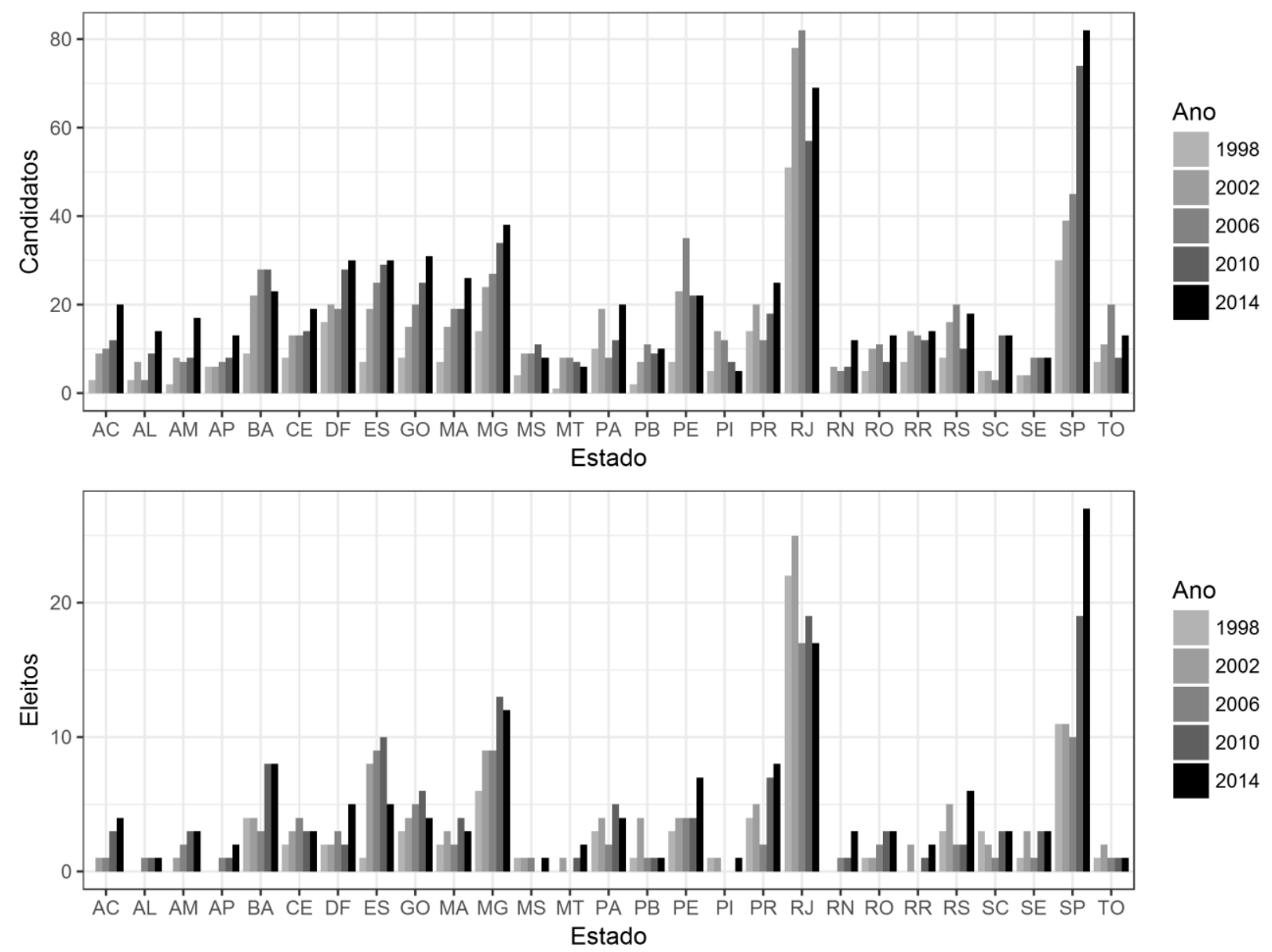

Fonte: Banco de dados de candidaturas evangélicas.

O número de candidatos eleitos por estado segue uma tendência semelhante à do número total de candidatos. Mais uma vez, o Rio de Janeiro se destaca, tendo sido superado por São Paulo apenas em 2014. Além de São Paulo e Rio, Minas Gerais também desponta com um número expressivo de candidatos eleitos. Trata-se, porém, de algo esperado, dado o fato de ser um estado populoso e com considerável população evangélica. Por outro lado, chama a atenção o desempenho do Espírito Santo, estado que, em 2010, possuía aproximadamente 1,2 milhão de evangélicos, mas que ainda assim apresentou, até 2010, um número de representantes evangélicos mais alto do que estados com maiores populações. Por fim, ao analisar os candidatos eleitos, percebe-se que, se a queda no número de representantes evangélicos em 2006 se deu em diversos estados, em nenhum foi tão forte como no estado do Rio. 
O próximo passo é investigar a distribuição dos candidatos evangélicos pelos partidos políticos brasileiros. Em que pese a presença de alguns partidos cristãos, cumpre destacar que não existem partidos formalmente evangélicos no sistema político brasileiro. Borges (2009), investigando a questão, observa que a identidade política é uma variável central para a formação dos partidos políticos. Todavia, tal identidade inexiste entre os evangélicos; não haveria uma identidade política que tornasse eleitores e deputados evangélicos brasileiros distintos dos demais grupos sociais. Até que ponto candidatos evangélicos têm preferência por certos partidos, ou, ao contrário, estão pulverizados pelos diferentes partidos brasileiros, é a questão a ser investigada a seguir.

O Brasil pós-Constituição de 1988 é o país com a maior fragmentação partidária do mundo (Clark, Gilligan e Golder 2006). Parte da literatura atribuiu tal característica a certas especificidades do sistema eleitoral brasileiro, tais como a representação proporcional de lista aberta, a alta magnitude dos distritos e a existência de coligações nas eleições para o legislativo (e.g., Lima Jr. 1999, Kinzo 1997). Essa relação, porém, ainda não é clara, e foi questionada por pesquisas recentes (cf. Calvo, Guarnieri e Limongi 2015). No Brasil, o número efetivo de partidos é similar tanto nos distritos de baixa como nos de alta magnitude, o que sugere que há outras explicações para o fenômeno da fragmentação.

A distribuição partidária dos evangélicos no Brasil é bastante pulverizada. Em 1998, candidatos evangélicos foram eleitos por 15 partidos diferentes (considerando eleições para a Câmara e Assembleias). Em 2002, o número aumentou para 18; em 2006, recuou para 17; em 2010, subiu para 19; e, por fim, chegou a 23 em 2014. Por si só, esse quadro pouco revela, e poderia estar de acordo com a tendência de aumento na fragmentação do sistema partidário brasileiro nas últimas eleições. Porém, como se pode ver abaixo, a distribuição dos evangélicos está longe de ser equilibrada ou aleatória. A Figura 9 apresenta o número de candidatos evangélicos total (eixo horizontal) e o número de evangélicos eleitos (eixo vertical) distribuídos entre os diferentes partidos brasileiros ${ }^{53}$. Foram incluídos no gráfico apenas os partidos que elegeram um ou mais candidatos evangélicos.

\footnotetext{
${ }^{53}$ Os partidos estão apresentados de acordo com sua sigla no momento da eleição. Vale lembrar que, em 2003, o Partido Progressista Brasileiro (PPB) alterou sua denominação para Partido Progressista (PP); em 2006, o Partido Liberal (PL) se fundiu ao Partido da Reedificação da Ordem Nacional (PRONA) para dar lugar ao Partido da República (PR); e, em 2007, o Partido da Frente Liberal (PFL) se transformou no Democratas (DEM).
} 
FIGURA 9. Candidatos evangélicos (total e eleitos) por partido político

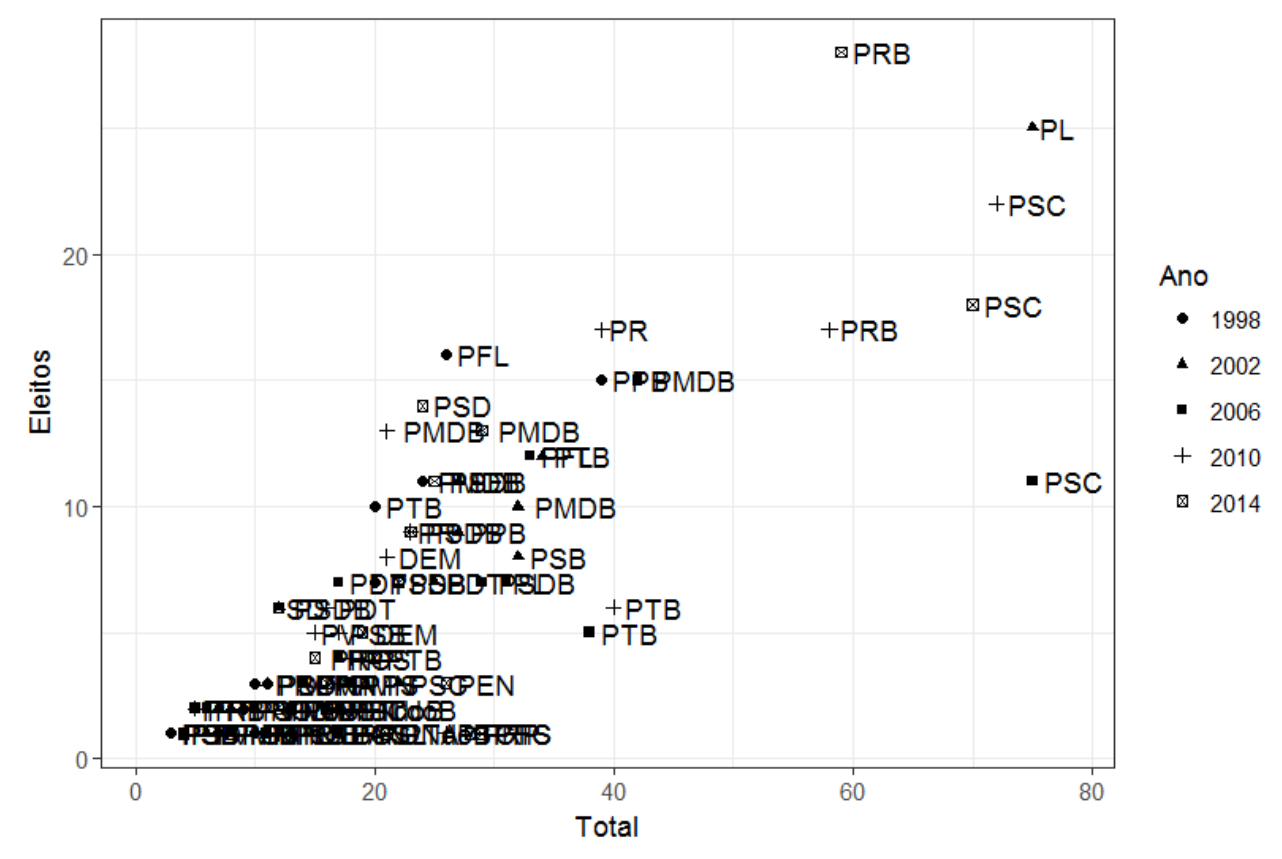

Fonte: Banco de dados de candidaturas evangélicas.

Nota-se que a grande maioria dos partidos se concentra no quadrante inferior esquerdo, indicando um número comparativamente menor de candidatos lançados e eleitos. Um número bem menor de partidos ocupa o centro do gráfico, e um número ainda menor está localizado no quadrante superior direito, o que representa um maior número de candidatos lançados e eleitos. Cabe destacar, nesse quadrante, a presença do Partido Republicano Brasileiro (PRB) e do Partido Social Cristão (PSC). Embora não sejam formalmente evangélicos, ambos os partidos se destacaram nas últimas eleições para o legislativo pelo número de candidatos evangélicos lançados e eleitos.

Criado em 2005, o PRB é considerado por muitos como «braço político» da IURD, fato negado tanto pelo partido como pela Igreja. Apesar da negação, a grande maioria dos candidatos da IURD entra na disputa eleitoral por meio do PRB, e é certamente o sucesso da Igreja que explica o alto sucesso de candidatos evangélicos do partido. O PSC, por sua vez, foi registrado em 1990. De acordo com seu Estatuto, define-se como partido sustentado na «Doutrina Social Cristã» ${ }^{54}$, e, segundo seu «Guia Rápido» para as eleições de 2014, defende «a vida e [a]

\footnotetext{
${ }^{54}$ Ver: http://www.psc.org.br/site/partido-social-cristao/documentos/estatuto.html (acessado pela última vez em $15 / 01 / 16)$.
} 
dignidade da pessoa humana; o respeito à ordem moral tradicional» e outros princípios ${ }^{55}$. Embora tampouco tenha vínculo formal com igrejas evangélicas, o partido, junto com o PRB, tem registrado grande número de candidatos evangélicos, que, sobretudo em 2010 e 2014, obtiveram notável sucesso eleitoral.

Vale ressaltar, por fim, que os partidos com maior representação evangélica, PRB e PSC, mesmo elegendo bancadas nos legislativos, têm pouca expressão nas eleições para o executivo. Em 2014, o PSC lançou candidato próprio para as eleições presidencias, o Pastor Everaldo Pereira, que terminou em quinto lugar e com $0,75 \%$ dos votos válidos. Os dois maiores partidos brasileiros com «vocação» para o executivo, o Partido dos Trabalhadores (PT) e o Partido da Social Democracia Brasileira (PSDB), ainda que não apareçam em destaque na Figura 9, distinguem-se entre si no que se refere ao número de candidatos evangélicos para o legislativo. Entre 1998 e 2014, o PT apresentou uma média por eleição de 5,2 candidatos evangélicos (para a Câmara e Assembleias somadas), elegendo 1,6. No mesmo período, o PSDB apresentou, em média, 21,8 e elegeu uma média de 8 .

\section{Comparando candidatos evangélicos e «candidatos oficiais» pentecostais}

Conforme discutido nas seções anteriores, a representação corporativa é um recurso institucional de candidatos de igrejas pentecostais. Segundo Freston (1993), ela seria responsável pelo notável crescimento da representação evangélica no Congresso brasileiro a partir de 1986. De fato, quase metade dos parlamentares evangélicos eleitos naquele ano eram candidatos oficiais pentecostais. Embora as implicações dessa mudança sejam diversas (o perfil ideológico e sócio-econômico dos novos candidatos, por exemplo, é diferente do dos antigos), e mereçam ser melhor investigadas, o foco da presente análise recairá na variação de candidatos oficiais pentecostais eleitos e no sucesso eleitoral das igrejas pentecostais. Para tanto, serão analisadas as seis igrejas pentecostais aludidas acima (AD, IEQ, IURD, IIGD, IMPD e Maranata). Embora possa haver outros candidatos oriundos de igrejas pentecostais, assumirei que o fenômeno da representação corporativa pentecostal pode ser razoavelmente mensurado a partir dessas seis igrejas. Não afirmo que não haja outras; apenas que essas seis são as mais significativas e as que melhor representam o fenômeno.

A Figura 10, abaixo, apresenta, para a Câmara e as Assembleias, o número de candidatos evangélicos eleitos e o número de candidatos corporativos pentecostais. O recorte temporal analisado (1998-2014) é curto, o que torna difícil qualquer tentativa de identificação de tendências de longo prazo. No entanto, algumas conclusões são possíveis. No caso do legislativo federal, é evidente que a participação das candidaturas pentecostais é alta e que vêm crescendo

\footnotetext{
${ }^{55}$ Ver: http://www.psc.org.br/site/partido-social-cristao/documentos/guia-rapido-eleicoes-2014.html (acessado pela última vez em 15/01/16).
} 
sobre o total de evangélicos. Essa participação alcançou seu maior nível em 2002. Naquele ano, de 42 evangélicos eleitos, 37 eram candidatos oficiais pentecostais, ou seja, quase $90 \%$. Em 2002, a participação pentecostal diminuiu, mas, mesmo apesar da queda, continuou crescendo até 2014, ano em que, de 67 evangélicos, 45 eram pentecostais $(\sim 68 \%)$.

No que se refere aos legislativos estaduais, a situação é semelhante. A menor participação pentecostal sobre o total de evangélicos eleitos foi em 1998, quando, de um total de 46 evangélicos eleitos, 30 eram pentecostais. Isso representa um percentual aproximado de $65 \%$. De 1998 em diante, esse percentual apenas aumentou, atingindo 79\% em 2014, quando 59 pentecostais foram eleitos entre o total de 75 evangélicos. Parece seguro afirmar, pois, que, seja para o nível federal, seja para o estadual, a participação corporativa pentecostal vem crescendo e é responsável por grande parte da representação evangélica nos legislativos brasileiros.

FIGURA 10. Número de pentecostais corporativos e evangélicos eleitos
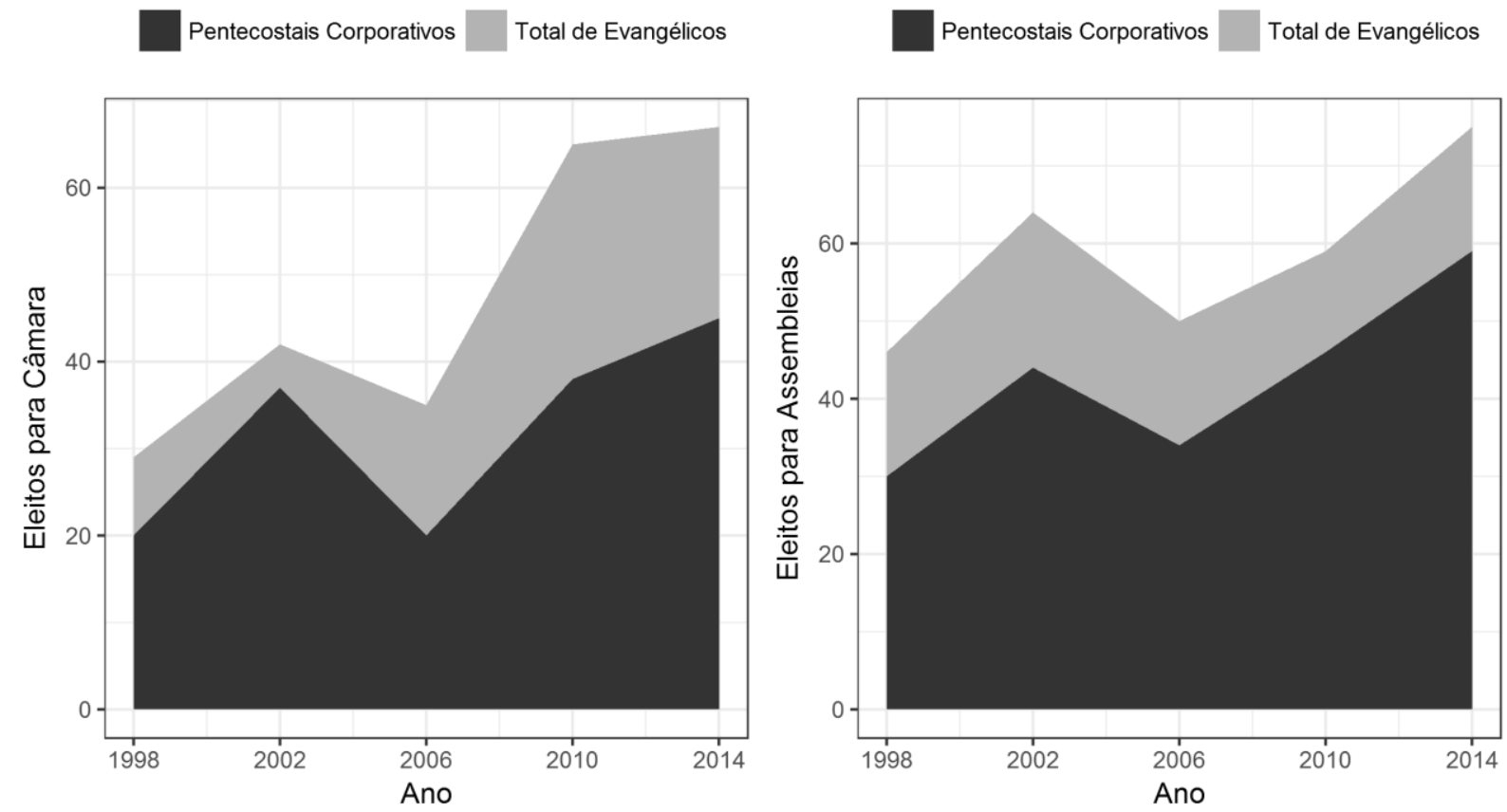

Fonte: Banco de dados de candidaturas evangélicas.

Uma segunda questão a ser investigada diz respeito ao sucesso eleitoral das igrejas pentecostais que adotaram o modelo de representação corporativa. Por um lado, a crescente participação corporativa pentecostal supõe que essas igrejas logrem obter algum sucesso eleitoral. Por outro lado, o grau desse sucesso é um problema até então não enfrentado pela literatura. Os poucos estudos sobre o tema corroborariam a hipótese de alto sucesso eleitoral por parte das igrejas pentecostais. Fernandes (1998), por exemplo, encontrou, por meio de survey 
aplicado na região metropolitana do Rio de Janeiro, que $87 \%$ dos fiéis da AD reportavam votar em candidatos da própria igreja; o percentual chegaria a 95\% no caso dos fiéis da IURD (1998, p. 126). Seu estudo é citado com frequência como evidência do alto grau de adesão dos fiéis pentecostais aos candidatos de suas igrejas.

Apesar do pouco número de evidências empíricas sobre a adesão dos fiéis eleitores aos candidatos pentecostais (e, por extensão, do sucesso eleitoral desses últimos), a maior parte da literatura sobre pentecostais e política na América Latina assume que tal adesão é alta. Ela seria um componente explicativo importante no argumento mais geral sobre como políticos pentecostais reproduziriam práticas clientelistas para ter acesso a recursos estatais (cf. Chesnut 1997, Gaskill 1997, Bastian 1994, D’Epinay 1970). Nessa visão, líderes pentecostais se valeriam de seus «currais» para oferecer apoio eleitoral a candidatos a cargos executivos, que, se eleitos, ofereceriam benesses aos pentecostais; ou, então, o apoio eleitoral dos fiéis seria usado por líderes pentecostais para conquistar assentos no legislativo, de onde poderiam, mais uma vez, beneficiar suas bases por meio de políticas paroquiais. Embora tal argumentação se assente numa série de hipóteses empíricas que, salvo engano, ainda carecem de testes, chamo a atenção aqui apenas para um aspecto, a saber, o sucesso eleitoral dos candidatos pentecostais. A argumentação acima exposta se fundamenta na suposição de que candidatos pentecostais gozam de alto apoio eleitoral da parte de seus fiéis. Se isso for verdade, então é de se esperar que os candidatos das igrejas pentecostais apresentem um alto grau de sucesso eleitoral.

Contudo, a Figura 11 revela um quadro que, se não nega peremptoriamente essa suposição, tampouco a confirma. Abaixo são apresentados o número total de candidatos lançados e eleitos pelas seis igrejas (inclui Câmara e Assembleias estaduais). Uma primeira observação a ser feita é que, embora a presente análise tenha se focado em seis igrejas, três dela (IIGD, IMPD e Maranata) apresentam um número de candidatos muito inferior ao das demais. Em 2014, a IIGD e a IMPD tiveram um aumento significativo e lançaram oito e 13 candidatos, respectivamente, mas só elegeram quatro e sete. Nos demais anos, ambas as igrejas não chegaram a lançar mais do que seis candidatos. Em relação à Maranata, a igreja chegou a eleger quatro de seis candidatos lançados em 2006, repetindo o mesmo desempenho em 2010. Porém, em 2014 declinou, e, apresentando cinco, elegeu apenas um.

O quadro de AD, IEQ e IURD é diferente, mas, no seu conjunto, tampouco corrobora a suposição de um alto grau de sucesso eleitoral. Por ser a maior igreja evangélica do Brasil, não surpreende que a $\mathrm{AD}$ apresente um número de candidatos maior que o das demais. Por outro lado, é notável o crescimento de seu número de candidatos, tanto o total quanto o de eleitos. Das três igrejas, trata-se da única que apresenta tendência de crescimento. Em 2014, a AD lançou 109 candidatos e elegeu 57, pouco mais de metade. Porém, foi o único ano em que isso ocorreu; em nenhum outro pleito a $\mathrm{AD}$ elegeu mais de $50 \%$ dos candidatos. 
O quadro da IEQ revela uma considerável variação de candidatos apresentados ao longo do período. Chegou a apresentar 30 candidatos em 2002, mas apenas 17 em 2014. Considerando o período como um todo, a igreja manteve um desempenho constante: elegeu seis de um total de 17 candidatos em 1998, e oito de um total de 17 em 2014. De modo semelhante à AD, em nenhum pleito a IEQ obteve mais de $50 \%$ de sucesso eleitoral.

Se há uma igreja que poderia encarnar o protótipo da representação corporativa pentecostal, essa igreja é a IURD. É, também, o caso do qual mais se esperaria um alto grau de sucesso eleitoral. $\mathrm{O}$ poder político e midiático da igreja vem sendo enfatizado não apenas pela mídia, senão também pela academia brasileira (e.g., Mariano 2004, Oro 2003). A Figura 11 revela um quadro para a IURD diferente do das demais. Em 1998 e 2014, a Universal conseguiu eleger uma parcela considerável dos candidatos que apoiou. Em 1998, dos seus 39 candidatos, 31 foram eleitos; em 2014, de 38 candidatos apresentados, a igreja elegeu 27. Não obstante, vale observar que, até 2002, foi a igreja que mais elegeu representantes para o legislativo. A fase de dominância da AD só começaria a partir de 2006 (isso, é claro, em números absolutos; em termos relativos, a IURD sempre elegeu mais). Porém, mesmo no caso da IURD, nota-se que, a despeito de ser o caso prototípico de representação corporativa pentecostal, a Universal está longe de eleger todos os seus candidatos, e, em 2006 e 2010, elegeu menos de $50 \%$.

FIGURA 11. Número de candidatos (total e eleitos) por igreja pentecostal
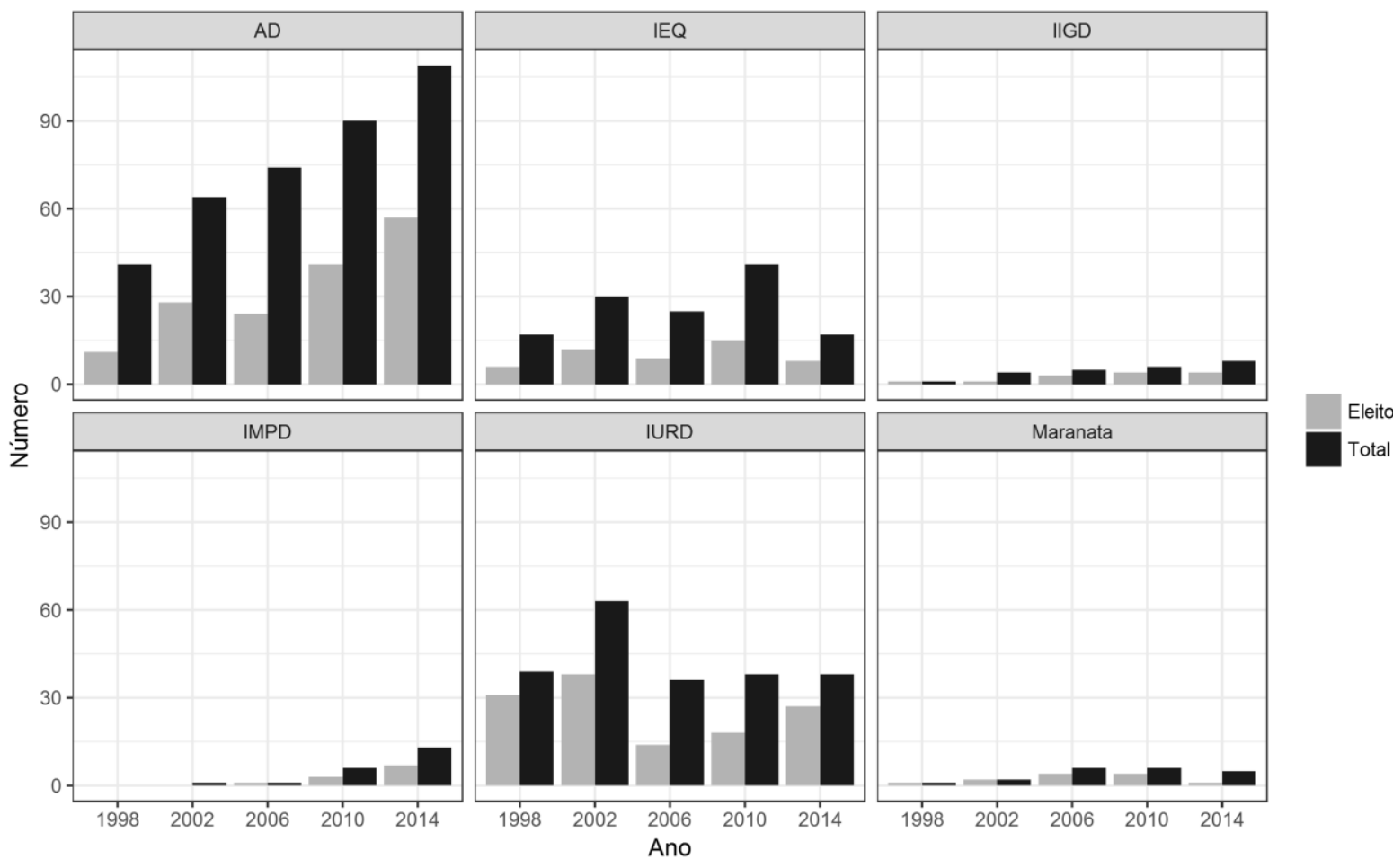

Fonte: Banco de dados de candidaturas evangélicas. 
Poderia ser argumentado que o objetivo das igrejas não é eleger todos os seus candidatos. Este é um ponto importante. É claro que, mesmo não tendo um alto grau de sucesso eleitoral, as igrejas já se beneficiariam por eleger alguns deputados. É razoável supor que elas possuam diferentes objetivos ao apresentar candidatos nas eleições e que alguns deles podem ser realizados sem que todos sejam eleitos. Em entrevista, um deputado estadual do PSDB-SP me disse que uma das razões pelas quais a IURD elegia deputados era para se beneficiar do foro privilegiado $^{56}$. A objeção é válida, mas erra o alvo. Não estou dizendo que, ao não eleger todos os seus candidatos, as igrejas pentecostais fracassam. Estou dizendo apenas que seu desempenho eleitoral é inferior ao que a literatura faria supor. Com isso, a hipótese do uso clientelista ou fisiológico das igrejas pentecostais perde parte de sua plausibilidade.

Por fim, vale notar a relação entre a queda no número de candidatos evangélicos eleitos em 2006, visível na Figura 7, e a queda apresentada pelas três principais igrejas pentecostais, AD, IEQ e IURD, no mesmo ano. Todas elegeram menos candidatos em 2006 do que em 2002, mas nenhuma queda foi tão grande quanto a da IURD, que elegeu 38 candidatos em 2002, e apenas 14 em 2006.

\section{Conclusão}

Até hoje, a maior parte da literatura sobre pentecostalismo e política na América Latina enfatizou o modo como igrejas pentecostais atuariam de modo clientelista e contribuiriam para a promoção das estruturas de dominação existentes. Essa argumentação se assentaria em várias hipóteses, sendo uma delas a de que líderes pentecostais obtêm grande apoio eleitoral de seus fiéis. Tal apoio seria usado essencialmente de duas formas: para barganhar com candidatos a cargos executivos, que, em troca, retribuiriam o apoio com benesses às igrejas; e para eleger «candidatos oficiais» das igrejas ao poder legislativo, que, uma vez eleitos, promoveriam políticas paroquiais para beneficiá-las. As poucas evidências encontradas na literatura sobre o grau do apoio eleitoral dos fiéis aos candidatos das igrejas iriam nessa direção.

Porém, o presente trabalho revela um quadro mais complexo. Em primeiro lugar, a proporção de candidaturas evangélicas para o legislativo vem se mantendo estável desde 2002. O número de evangélicos eleitos, embora tenha aumentado entre 1998 e 2014, permanece muito abaixo do que seria necessário para uma representação proporcional ao número de evangélicos na população brasileira. Em segundo lugar, embora sub-representados, os evangélicos devem seu crescimento na Câmara dos Deputados e nas Assembleias Legislativas em grande medida aos «candidatos oficiais» de igrejas pentecostais. Qualquer discussão normativa sobre a

\footnotetext{
${ }^{56}$ No Brasil, ações penais contra deputados e políticos em geral tramitam em Tribunais, e não nos Juízos de primeira instância.
} 
representação política dos evangélicos e sua relação com a democracia brasileira deveria levar em conta esse fato. Em terceiro lugar, as igrejas pentecostais que adotaram o modelo corporativo de representação política apresentam um sucesso eleitoral muito menor do que a literatura e a mídia fariam supor. $\mathrm{O}$ desempenho eleitoral das igrejas apresentado aqui leva a crer que, ainda que obtenham apoio de seus fiéis, dificilmente ele poderia ser caracterizado como irrestrito ou mesmo oferecido por 80 ou 90\% dos fiéis, como encontrou Fernandes (1998).

O quadro resumido acima parece contraditório, mas não o é. As igrejas pentecostais não são tão bem-sucedidas eleitoralmente quanto se assevera. Embora tenham alguma «força» eleitoral, não elegem todos os seus candidatos. No entanto, essa afirmação não é incompatível com a ideia de que o modelo corporativo de representação política é em grande medida responsável pela representação dos evangélicos no legislativo brasileiro. As consequências das conclusões sumarizadas aqui são diversas e podem indicar caminhos para novas pesquisas sobre o tema. Cito, a seguir, três possibilidades. Uma primeira questão a se pontuar é a da mudança no perfil parlamentar provocada pelo crescimento do número de políticos evangélicos, e de até que ponto o crescimento das «candidaturas oficiais» pentecostais não seria um fator determinante para a diversificação do perfil parlamentar brasileiro. Uma segunda questão diz respeito aos casos de insucesso eleitoral de «candidatos oficiais» pentecostais, sua explicação e, de modo mais geral, as variáveis conjunturais que poderiam impactar o apoio dado a esses candidatos por eleitores de suas igrejas. Por fim, uma terceira questão, não necessariamente relacionada às conclusões elencadas neste trabalho, trata do comportamento político dos parlamentares evangélicos. Ainda faltam estudos que corroborem ou questionem as hipóteses hoje predominantes sobre a atuação parlamentar dos políticos pentecostais. 


\section{Capítulo 3}

\section{Estimando o Efeito de Ser Candidato Pentecostal sobre o Voto nas Eleições Brasileiras de 2014}

«A força da candidatura não está no meu nome. Se não fosse eu, seria outro e seria eleito da mesma forma; com absoluta certeza.» - Paulo Gouvea (PL-RS), pastor da IURD ${ }^{57}$

\section{Introdução}

Desde o lançamento de $O$ Refúgio das Massas, obra seminal de d'Epinay (1970), é comum encontrar na literatura das ciências sociais sobre religião e política na América Latina a ideia de que políticos pentecostais poderiam contar com sólido apoio eleitoral dos seus fiéis, caracterizados como «curral» ou «rebanho eleitoral» desses políticos.

A evidência de apoio eleitoral sólido ao candidato pentecostal não corrobora, por si só, o argumento do «rebanho eleitoral», mas é condição necessária para ele. Além disso, é necessária também para a própria caracterização das «candidaturas oficiais» pentecostais (cf. Freston 1993). No entanto, até hoje, evidências nesse sentido foram apresentadas apenas por estudos de um ou poucos casos. Tento contribuir para preencher essa lacuna, oferecendo evidências quantitativas para responder a importantes perguntas sobre a representação política dos evangélicos no Brasil: candidatos pentecostais arrecadam mais ou menos recursos de campanha do que os demais candidatos? Qual é o efeito de ser candidato pentecostal sobre o voto nas eleições para o legislativo no Brasil? O tipo e a estrutura da igreja são relevantes para tal efeito?

Na seção seguinte, retomo brevemente a literatura sobre evangélicos e política, bem como a discussão sobre os determinantes do sucesso eleitoral dos deputados no Brasil. Na seção 3, a partir da literatura, desenvolvo a teoria e formulo as hipóteses que serão testadas. Na seção 4, apresento e descrevo os dados e variáveis utilizados. Na seção 5, apresento os resultados e achados. Na seção 6, ofereço evidências qualitativas de candidatos apoiados por igrejas pentecostais que perderam o apoio delas ao longo do mandato, decidiram concorrer à reeleição e não foram reeleitos. Essas evidências ressaltam a importância do apoio das igrejas aos candidatos pentecostais e servem como argumento contrafactual de que, estivesse o apoio das igrejas

\footnotetext{
${ }^{57}$ Entrevistado por Oro (2003).
} 
ausente, os candidatos não teriam sido eleitos. Por fim, na última seção discuto os achados e apresento comentários finais.

\subsection{Pentecostais e eleições}

$\mathrm{O}$ crescimento da população evangélica na América Latina ao longo do século XX despertou o interesse de estudiosos das ciências sociais sobre as causas e possíveis consequências do fenômeno. Desde o início, uma das preocupações dos pesquisadores foi com a relação entre o crescimento pentecostal e a política latino-americana. Desde o início, também, os estudos apresentaram diferentes visões e prognósticos. Enquanto alguns sugeriram que o crescimento do protestantismo poderia ter efeitos positivos sobre as democracias da região (e.g., Willems 1967; Stoll 1990; Martin 1990; Mariz 1992; Smith 1994; Dodson 1997), outros ressaltaram os possíveis efeitos negativos (e.g., d'Epinay 1970; Bastian 1994; Chesnut 1997; Gaskill 1997). Nessa última visão, as igrejas pentecostais ingressariam na política promovendo práticas clientelistas e nocivas à democracia. Líderes pentecostais atuariam como brokers, supostamente controlando os votos de suas congregações e se valendo deles para manterem estruturas sociais injustas. No caso do Brasil, bispos e pastores seriam recrutados por partidos políticos - normalmente de centro ou direita - para disputarem eleições para os legislativos municipais, estaduais e federal ${ }^{58}$. Uma vez eleitos, eles beneficiariam suas igrejas com políticas paroquiais. O argumento aventado se baseia na suposição de que o «rebanho eleitoral» das igrejas ofereceria considerável grau de apoio eleitoral a seus líderes.

Desde a década de 1990, os estudos focados no caso brasileiro notaram que a entrada de líderes evangélicos nas disputas para o legislativo foi um fenômeno circunscrito a um pequeno conjunto de igrejas pentecostais. O processo se iniciou com a Assembleia de Deus (AD) e a Igreja Universal do Reino de Deus (IURD), sendo, mais tarde, emulado por outras igrejas. Outro fato digno de nota é que, em que pesem as diferenças organizacionais, essas igrejas passaram a lançar «candidatos oficiais» para os pleitos legislativos, i.e., apoiados oficialmente pelas igrejas (cf. Freston 1993).

O crescimento do número de candidatos pentecostais eleitos durante a redemocratização levou cientistas sociais a se perguntar sobre qual seria a «força» desses candidatos, bem como sobre o grau de apoio das congregações a seus líderes. É preciso destacar, nesse sentido, a importância do survey realizado por Fernandes (1998) na região metropolitana do Rio de Janeiro. Focado exclusivamente na população evangélica, o estudo revelou que, ao serem questionados

\footnotetext{
58 A Igreja Universal e o Partido Republicano Brasileiro (PRB) constituem, em certo sentido, uma exceção. Neste caso, não se trataria propriamente de um partido recrutando candidatos de uma igreja, mas, antes, de uma igreja «criando» um partido para, por meio dele, lançar seus candidatos. Note-se, no entanto, que não há vínculo formal ou estatutário entre o PRB e a IURD.
} 
sobre em quem tinham votado, $87 \%$ dos fiéis da $\mathrm{AD}$ respondiam ter escolhido candidatos da própria igreja. No caso dos fiéis da IURD, esse percentual chegava a 95\%. Os fiéis da Igreja Batista e das demais igrejas históricas disseram votar mais em candidatos pentecostais do que nos das próprias denominações ${ }^{59}$.

Embora limitadas ao Rio de Janeiro e a apenas uma eleição, as evidências de Fernandes foram citadas com frequência na literatura como indício de alto apoio dos fiéis evangélicos a candidatos de igrejas. Desde então, um número ainda pequeno, embora crescente de pesquisadores continuou se debruçando sobre o tema. Pela própria natureza do trabalho, a investigação sobre a relação entre candidatos evangélicos e suas igrejas exige estudos de caso que se aprofundem em uma igreja e/ou região específicas (e.g., Schoenfelder e Paz 2006; Borges Jr. 2010; Valle 2013; Barbosa 2015). Esses estudos revelaram que igrejas como a Assembleia de Deus, Igreja Universal do Reino de Deus e Igreja do Evangelho Quadrangular (IEQ) se mobilizam para que seus fiéis votem nos candidatos da igreja para o legislativo.

O crescimento da representação política dos evangélicos no Brasil se deu graças ao sucesso de candidatos pentecostais apoiados por suas igrejas. Até hoje, os casos mais ilustrativos e citados por pesquisadores foram os da AD, IURD e IEQ. No entanto, outras igrejas pentecostais também apoiam candidatos oficiais, tendo inclusive sido objeto de atenção da mídia $^{60}$. Vale destacar que, no Brasil, é proibido fazer propaganda política em igrejas e templos religiosos (Lei 9.504/97, Art. 37). A proibição não é específica a igrejas. É, antes, uma proibição de caráter geral contra a propaganda política em bens de uso público (e/ou bens cujo uso dependa de cessão do poder público), tais como cinemas, clubes, lojas, centros comerciais e templos religiosos. A lei é vaga, dando margem considerável para discussão sobre quais atividades e discursos se constituiriam em propaganda política e onde elas não poderiam ser feitas.

De modo geral, o desempenho eleitoral dos candidatos pentecostais parece relacionado ao perfil da igreja que o apoia. Algumas variáveis seriam de particular relevância, tais como o tamanho da igreja (número de templos, número de fiéis), a estrutura midiática, o grau e ênfase no apoio oferecido e a centralização decisória. Em outras palavras, quanto maior for a igreja em termos de estrutura e número de fiéis, quanto maior e mais enfático for o apoio dado pela instituição aos candidatos, e quanto mais centralizada for sua estrutura eclesial, maior será a

\footnotetext{
${ }^{59}$ A pesquisa de Fernandes (1998) entrevistou 1.332 pessoas. Vale destacar que pesquisa amostral de 2013 do Instituto Datafolha encontrou resultados diferentes. Segundo a pesquisa, apenas 18\% dos evangélicos pentecostais disse já ter votado em algum candidato recomendado por sua igreja. Obviamente, esses resultados devem ser vistos com alguma cautela. É provável que, devido a um viés de desejabilidade, muitos respondentes optem por dizer que nunca seguiram a orientação de sua igreja ou pastor, mesmo já o tendo feito. Disponível em: $<$ http://datafolha.folha.uol.com.br/opiniaopublica/2013/07/1314857-fatia-de-catolicos-e-a-menor-em-duasdecadas.shtml>

${ }^{60}$ Ver, por exemplo: «TRE faz operação em igrejas evangélicas de Caxias e apreende material de candidatos» $(O$ Globo, 17/09/14); e «Deputados ligados à Igreja Mundial são cassados por 'abuso de poder religioso'» (Gospel Prime, 1/09/15).
} 
probabilidade de sucesso eleitoral. A centralização decisória está relacionada ao processo de seleção de candidatos. Numa igreja em que há forte centralização decisória, os candidatos são selecionados pela hierarquia e os não selecionados não podem competir. Por outro lado, a ausência de centralização faz com que o processo de seleção seja menos controlado, permitindo que mesmo aqueles que não foram oficialmente selecionados ainda assim tentem disputar os votos da congregação.

A IURD aparece como o caso prototípico de representação corporativa pentecostal. Além de estar entre as maiores igrejas pentecostais brasileiras, é conhecida por ser mais enfática no apoio a seus candidatos do que as demais, e, certamente, possui uma das mais centralizadas estruturas eclesiais do país (cf. Oro 2003; Mariano 2004; Barbosa 2015). A AD, em contrapartida, mesmo sendo a maior igreja evangélica do Brasil, é relativamente descentralizada e, ao menos até 2014, não possuía controle de candidaturas rigoroso. A igreja permite que membros se lancem candidatos mesmo sem ter sido vitoriosos nas prévias internas. Com isso, os votos dos fiéis acabam dispersos entre vários candidatos (cf. Borges Jr. 2010). Por fim, a IEQ possui número de fiéis próximo ao da IURD, mas, embora desde 2000 conte com uma estrutura organizacional e lance candidatos oficiais (cf. Schoenfelder e Paz 2006), o processo não parece tão controlado como o da Universal, nem implica em «pressão» sobre os fiéis, tal como ocorre com os fiéis iurdianos.

A hipótese de que há relação entre o desempenho dos candidatos pentecostais e o perfil de sua igreja supõe que os votos recebidos pelos candidatos provêm da própria congregação. No entanto, pode-se aventar também que parte deles venha de outros eleitores evangélicos ${ }^{61}$. Nas eleições proporcionais brasileiras, vem crescendo o número de candidatos que se valem de títulos evangélicos em seu «nome de urna». $\mathrm{O}$ aumento do número de candidatos bispos e pastores sugere que tal estratégia possa servir como uma «pista» religiosa para atrair eleitores evangélicos, sinalizando-lhes a identidade evangélica do candidato. A estratégia se explicaria pelas características do sistema político brasileiro: alta fragmentação partidária, partidos com «marcas» fracas, alto número de candidaturas para o legislativo (decorrência da alta magnitude dos distritos) e campanhas caras. Boas (2014) usou um experimento de survey para aferir o efeito de títulos religiosos no nome de urna sobre a preferência dos eleitores. Os respondentes foram confrontados com um candidato fictício, e, para o grupo de tratamento, o candidato era apresentado com o título de «Pastor». O uso do título reduziu as intenções de voto do candidato

\footnotetext{
${ }^{61}$ Em entrevista a Borges Jr. (2010), o deputado maranhense e líder da AD Costa Ferreira afirma que «95\% dos seus votos procedem do meio evangélico» (p. 75). De modo semelhante, a deputada Eliziane Gama, também da AD maranhense, diz que «90\% de seu eleitorado também são de evangélicos» (idem). As afirmações não são claras, mas dão a entender que os deputados da $\mathrm{AD}$ não receberiam votos apenas de eleitores da $\mathrm{AD}$, senão também do eleitorado evangélico em geral.
} 
para os respondentes não-evangélicos, mas aumentou as intenções de voto para os respondentes evangélicos (ambos os resultados com significância estatística) ${ }^{62}$.

Seja por contar com o apoio dos membros da própria igreja, seja por contar com o apoio de eleitores para os quais sinalizam sua identidade religiosa, candidatos pentecostais poderiam, em tese, disputar eleições proporcionais no Brasil contando com um número considerável de votos e tendo, ao mesmo tempo, campanhas comparativamente pouco custosas. A relação entre voto e gasto de campanha foi investigada por Figueiredo Netto e Speck (2015). Os autores partiram da hipótese geral de que evangélicos receberiam mais votos tendo menos recursos financeiros e usaram dados das eleições de 2014 para a Câmara dos Deputados e Assembleias estaduais. Seu estudo considerou como evangélicos os candidatos que usaram títulos («bispo», pastor», etc.) evangélicos nos nomes de urna. A partir de regressões OLS, eles testaram se, de fato, «pastores» receberiam menos recursos do que os demais candidatos, e se, apesar disso, ser pastor teria algum efeito sobre os votos do candidato. Seus resultados indicam que pastores receberiam menos recursos, mas ser pastor não teria efeito positivo sobre os votos. No entanto, ao interagir a variável dummy «pastor» com o gasto de campanha, haveria um efeito positivo e com significância estatística.

Embora parta de um bom insight, o trabalho de Figueiredo Netto e Speck não usa os dados adequados para testar suas hipóteses. Os autores usam títulos religiosos como «proxy» de candidatos evangélicos. Porém, muitos candidatos evangélicos não usam títulos em seus nomes de urna, e é certo que o uso do título religioso por parte dos candidatos não é aleatório, mas, ao contrário, está correlacionado com outras variáveis. A figura 12, abaixo, apresenta a dispersão do \% de votos válidos dos candidatos evangélicos para a eleição da Câmara dos Deputados de 2014.

\footnotetext{
${ }^{62} \mathrm{O}$ aumento foi de .31 numa escala de 7 pontos $(p<0.1)$. A pergunta feita foi: «quão inclinado(a) você estaria a votar nesse candidato?».
} 
FIGURA 12. Votação dos candidatos evangélicos

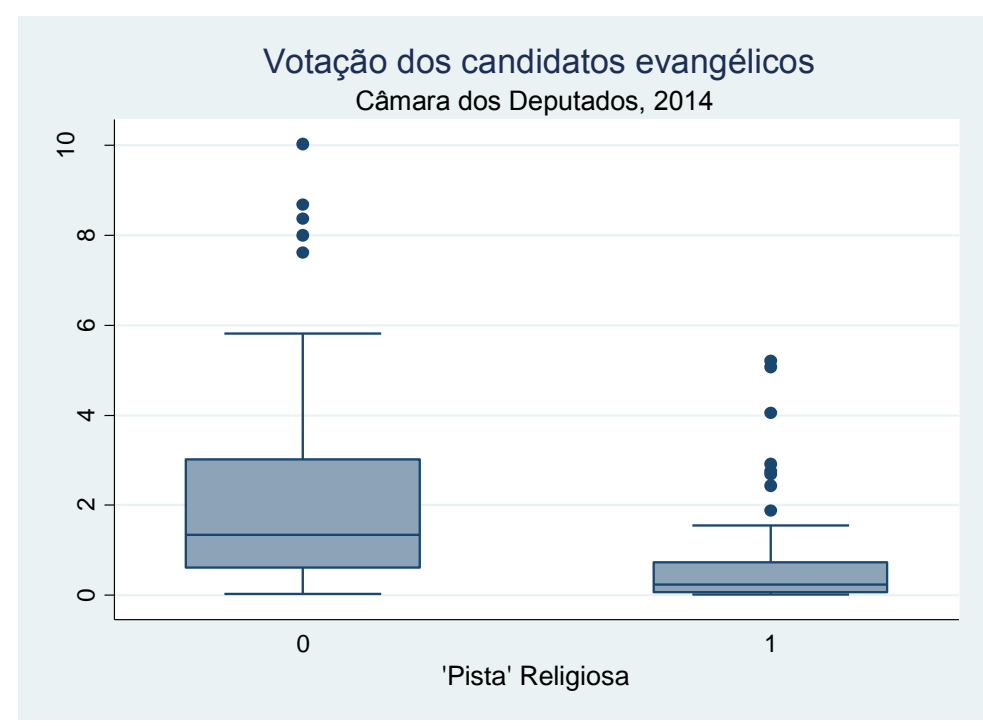

Fonte: Banco de dados de candidaturas evangélicas.

Os candidatos estão divididos entre aqueles que usam títulos religiosos em seus nomes de urna (valor 1) e os que não usam (valor 0). Nota-se que o \% de votos dos candidatos evangélicos sem título religioso é superior ao daqueles com título. O quartil superior (a parte superior da "caixa") dos evangélicos sem título é muito superior ao valor máximo dos evangélicos com título. Considerei mais razoável incluir apenas os candidatos que tiveram $0.02 \%$ ou mais de votos na eleição (o que dá um total de 150 evangélicos); porém, se considerasse o total de candidatos evangélicos, a diferença entre os dois grupos seria ainda maior. Não é racional supor que os candidatos optem por usar títulos religiosos que vão lhes causar perda de votos. A hipótese mais plausível, ao contrário, é que o título religioso é um recurso usado por candidatos evangélicos menos competitivos, sendo desnecessário (ou até mesmo contra-producente) para os mais competitivos. Desse modo, qualquer modelo que use títulos religiosos como «proxy» de candidatos evangélicos estará enviesado ${ }^{63}$.

Antes de avançar para a construção de meu modelo teórico, é necessário uma revisão breve da literatura sobre o desempenho dos candidatos às eleições para o legislativo no Brasil. Essa revisão pode contribuir para a identificação de elementos importantes a qualquer modelo esteja ou não preocupado com evangélicos - que tente explicar os determinantes do voto nas eleições brasileiras.

\footnotetext{
${ }^{63}$ O exemplo da IURD corrobora meu argumento. Em 2014, dos 19 candidatos a deputado federal lançados pela igreja, apenas dois usaram títulos religiosos.
} 


\subsection{Explicando o desempenho nas eleições para o legislativo}

O gasto de campanha nas eleições para o Congresso dos EUA começou a crescer a partir da década de 1960, fato que chamou a atenção de congressistas e pesquisadores. Por conta disso, no início da década de 1970, foi aprovado o Federal Election Campaign Act, que obrigou os candidatos a tornarem públicos seus gastos de campanha. A partir daí, estudiosos puderam se debruçar sobre a relação entre dinheiro e voto nas eleições americanas. A questão central nessas pesquisas era entender como o gasto afetaria os resultados eleitorais.

O debate sobre gasto de campanha e voto nas eleições para o legislativo se tornou um dos mais importantes campos da ciência política. A literatura é volumosa e não pretendo oferecer uma revisão abrangente ${ }^{64}$. Vou me limitar a algumas considerações, na medida em que elas possam contribuir para a construção de meu próprio modelo. Ao se estudar os fatores determinantes no desempenho eleitoral de candidatos para o legislativo, uma referência incontornável é o gasto de campanha. A questão, no entanto, está longe de ser simples. Scholars vêm tendo dificuldade em estabelecer uma relação causal sólida entre gasto e voto. Jacobson (1978, 1985, 1990) investigou a relação entre gasto e voto nas eleições para o Congresso dos EUA e foi um dos primeiros a defender que o gasto de campanha tem efeitos muito diferentes para incumbents e challengers. No cenário eleitoral americano, quanto mais o desafiante gastar, maior será seu percentual de votos. Em contrapartida, quanto mais o incumbente gastar, menor será sua parcela de votos. Isso não significa, é claro, que incumbentes percam votos ao gastar dinheiro, mas apenas que precisam gastar mais dinheiro quanto mais forte for seu desafiante ${ }^{65}$.

O problema, porém, é que a relação entre dinheiro e voto é recíproca. O dinheiro arrecadado pelos candidatos depende da expectativa de quão bem se sairão na eleição. $O$ dinheiro arrecadado afeta o voto, mas a expectativa do voto afeta o dinheiro arrecadado. Por conta disso, modelos OLS produziriam estimadores inconsistentes e enviesados (Jacobson 1990). Os estudiosos vêm enfrentando esse problema de diferentes formas. Uma delas é o uso de two stage least square regressions (TSLS); outra é o uso de melhores variáveis de controle. Green e Krasno (1988), por exemplo, em sua crítica a Jacobson, propõem que os modelos incorporem uma medida da qualidade política dos desafiantes.

Uma conclusão parcial a ser feita sobre as eleições americanas é que, primeiro, o gasto do desafiante importa mais que o do incumbente; segundo, não há consenso sobre o quão

\footnotetext{
${ }^{64}$ Para uma boa revisão parcial, ver Stratman (2005).

${ }^{65}$ A explicação para o efeito distinto para desafiantes e incumbentes seria que esses últimos usam seu mandato para encher os distritos com propaganda e informações sobre si próprios e suas virtudes - tudo isso antes de a campanha formal começar. Por conseguinte, o gasto do incumbente após o início da campanha lhe traz comparativamente menos votos. Os desafiantes, em contraste, começam a campanha na obscuridade e precisam gastar muito dinheiro para se fazer conhecer (Jacobson 1990).
} 
importante é o gasto do incumbente; e terceiro, apesar disso, a média de gasto dos incumbentes é mais de três vezes maior do que a dos desafiantes (Stratman 2005).

As conclusões sobre o caso americano são importantes, mas é preciso lembrar que há diferenças consideráveis entre ele e o caso brasileiro. No sistema distrital dos EUA, a disputa num distrito se dá, na prática, entre um incumbente e um desafiante. No Brasil, em contrapartida, o sistema de representação proporcional de lista aberta faz com que, dentro de cada distrito, haja diversos incumbentes e diversos desafiantes. Nas eleições legislativas de 2014 para o estado de São Paulo, por exemplo, a disputa para deputado federal se deu entre mais de mil desafiantes e 58 incumbentes (o estado possui 70 representantes).

Embora a literatura sobre o caso brasileiro se beneficie dos achados sobre o caso americano, há um número considerável de estudos, sobretudo a partir dos anos 1990, que se voltaram para a compreensão da especificidade das eleições legislativas no Brasil. Mais uma vez, não oferecerei uma revisão abrangente da literatura, apenas farei referência aos trabalhos mais relevantes para a construção de meu próprio modelo ${ }^{66}$.

Samuels (2001a, 2001b) foi um dos primeiros a investigar a relação entre gasto e voto para as eleições brasileiras usando dados de receitas e despesas disponibilizados pelo TSE. Os modelos de regressão OLS do autor têm como base os dados das eleições de 1994 e 1998 para a Câmara dos Deputados. Além de usar gasto como principal variável explicativa, Samuels usa como controles a magnitude do distrito, a incumbência e a qualidade dos candidatos - medida por meio de um índice do Instituto de Estudos Socio-econômicos (INESC) -, entre outros. O gasto de campanha aparece com efeito significativo, mas o mesmo não ocorre com a interação entre incumbência e gasto, sugerindo que, no Brasil, o gasto de campanha teria efeito semelhante entre incumbentes e desafiantes. Um último ponto a ser observado é que, para Samuels, não se deveria comparar os incumbentes com todos os desafiantes, mas tão-somente com aqueles mais fortes ou de maior qualidade.

Pereira e Rennó $(2001,2007)$ investigam os determinantes da reeleição para a Câmara dos Deputados. Os autores testam modelos probit com diversas variáveis independentes, tais como concentração de votos, grau de competição local, gasto de campanha, ideologia, pertença à coalizão dos governos estadual e federal, além de uma série de variáveis relativas à performance dos candidatos em seus mandatos. Cabe notar que Pereira e Rennó não trabalham com o total de candidatos, mas tão-somente com os candidatos que concorreram à reeleição. O número reduzido de candidatos lhes permite testar um número maior de variáveis. O primeiro estudo aborda a eleição de 1998, e o segundo, a de 2002. Os autores ressaltam que pertencer ao governo apresentou significância estatística em 1998, mas não em 2002. A explicação para isso seria a

\footnotetext{
${ }^{66}$ Para uma boa revisão da literatura sobre financiamento de campanha no Brasil, ver Mancuso (2015).
} 
ausência, em 2002, de um presidente concorrendo à reeleição. Leoni, Pereira e Rennó (2003) fazem um esforço semelhante ao dos dois estudos mencionados, porém buscando explicar os determinantes das escolhas de carreira dos deputados federais. As escolhas são divididas em quatro tipos básicos: aposentadoria; reeleição; cargos mais altos (ex.: governador); e cargos mais baixos (ex.: deputado estadual). Se a variável explicada é a escolha do legislador, as variáveis explicativas são idade, posições institucionais, participação em comissões, ideologia, pertença à coalizão do presidente, votos na eleição anterior e tamanho do distrito, entre outras.

Lemos, Marcelino e Pederiva (2010) investigam o custo das campanhas eleitorais para a Câmara e o Senado em 2002 e 2006. Eles se detêm sobre todos os candidatos que prestaram contas de seus gastos e assumem que, no caso brasileiro, não haveria «incumbency advantage». Baseando-se em estatística descritiva, os autores argumentam que os eleitos têm campanhas mais caras do que os não eleitos. A média de gastos dos eleitos é maior, tanto em 2002 quanto em 2006. Eles mostram também que o gasto de campanha dos incumbentes é maior do que o dos desafiantes. Cabe ressaltar, também, que partido político e pertença ao governo seriam duas variáveis relevantes para a arrecadação dos candidatos.

Speck e Mancuso (2014) também buscam explicar a relação entre gasto de campanha e sucesso eleitoral. Porém, seu foco recai sobre a interação entre gasto de campanha e incumbência, de um lado, e gasto e gênero, de outro. Os autores concluem que há uma associação positiva e com significância estatística entre gasto e sucesso eleitoral. Concluem, também, que há um «efeito Jacobson» para o caso brasileiro, e que ele se verifica não apenas para os desafiantes, mas também para candidatos com desvantagens eleitorais específicas (mulheres, por exemplo). Nesse sentido, «electoral finance would function as a tool capable of offsetting the negative effect of other factors in terms of electoral performance» (p. 51). A partir dos achados da literatura sobre evangélicos e eleições, bem como sobre os determinantes do desempenho eleitoral para as eleições proporcionais no Brasil, apresento, na seção seguinte, um modelo teórico e as hipóteses que serão testadas.

\section{Teoria e hipóteses: pentecostais, igrejas e gasto de campanha}

Um experimento ideal que medisse o efeito causal de ser candidato oficial pentecostal sobre o desempenho eleitoral precisaria atribuir aleatoriamente, num determinado distrito, o apoio oficial de igrejas pentecostais idênticas (o tratamento) a determinado grupo de deputados e comparar seu desempenho com o de outro grupo de deputados que não tivesse recebido tal apoio (grupo de controle). Por diversas razões, esse desenho de pesquisa é impraticável. Homens e mulheres não se convertem ao protestantismo pentecostal de forma aleatória, nem ascendem na hierarquia da igreja de forma aleatória. Por conseguinte, o apoio oficial da igreja não é dado de modo aleatório. Ademais, há extrema diversidade entre as igrejas pentecostais brasileiras. Elas se 
diferenciam em relação à extensão territorial, ao número de templos, pastores e fiéis, à sua doutrina e visão teológica, entre outros fatores. Portanto, nem o apoio é aleatório entre os candidatos, nem é dado por igrejas idênticas.

Em vez disso, ofereço um estudo observacional baseado em dados dos candidatos à Câmara dos Deputados e às Assembleias estaduais, por meio do qual pretendo estimar o efeito de ser candidato pentecostal sobre o desempenho eleitoral. Até hoje, a dificuldade na obtenção de dados sobre os candidatos evangélicos, bem como sobre sua relação com as igrejas, impediu que pesquisadores abordassem com sucesso o efeito eleitoral de ser evangélico com análises multivariadas. Partindo de novos dados (detalhados na seção seguinte), pretendo contribuir para preencher essa lacuna.

Admitindo que haja uma associação positiva entre ser candidato pentecostal e desempenho eleitoral, ela poderia ser explicada de diferentes maneiras. Uma primeira explicação básica é a da identidade evangélica. Identidades sociais baseadas em raça, gênero e religião, entre outras, podem gerar coesão política e serem relevantes na disputa eleitoral (cf. Huddy 2013; Green et al. 2002). Há evidências de que, para além de candidatos e partidos, grupos sociais são uma das principais formas pelas quais indivíduos organizam sua cognição política geral (cf. Miller et al. 1991). No caso das eleições para o legislativo no Brasil, o uso de títulos religiosos no «nome de urna» seria um exemplo de como certos candidatos buscam sinalizar sua identidade evangélica para os eleitores.

Uma segunda explicação se baseia no apoio que uma igreja oferece a seu candidato «oficial», conferindo-lhe um contingente de votos mais ou menos garantido (ou acesso facilitado a esse contingente). Os representantes da igreja - pastores e bispos - divulgam o candidato para os fiéis de variados modos: levando-os ao altar, colocando banners com fotos do candidato dentro ou nas proximidades da igreja, apresentado-o aos fiéis em encontros pessoais, divulgando material de campanha do candidato, entre outros (cf. Oro 2003b; Santos 2013; Valle 2013). Sendo a igreja uma instituição que preenche diversas esferas da vida do fiel, é compreensível que a confiança por ele depositada na instituição se transmita com facilidade para os candidatos apoiados por ela. Ademais, a estrutura sectária das igrejas pentecostais faz com que busquem manter os fiéis dentro das igrejas e se oponham à participação deles em esferas que fogem ao controle delas (cf. Freston 1993). Isso contribui para uma alta frequência ao culto vis-à-vis outras religiões (cf. Bohn 2004).

O apoio da igreja ensejou o surgimento de um novo tipo de candidato pentecostal, cujo aparecimento histórico se deu na década de 1980, durante a redemocratização (cf. Freston 1993). Embora, em teoria, seja possível falar nas duas explicações acima (identidade religiosa e apoio da igreja) como duas explicações distintas, a distinção é mais difícil na prática, já que candidatos 
«oficiais» de igrejas podem receber votos de eleitores evangélicos não pertencentes a sua igreja, e candidatos não-oficiais podem disputar votos de igrejas que já apoiam outro candidato.

De todo modo, as duas explicações básicas para a associação positiva entre ser candidato pentecostal e desempenho eleitoral permitem diferentes conjecturas sobre o gasto de campanha desses candidatos. Pode-se aventar que, quer seja pelas «pistas religiosas», quer seja pelo apoio oficial da igreja, candidatos pentecostais necessitem gastar proporcionalmente menos dinheiro em suas campanhas. Todavia, seria plausível aventar também uma explicação concorrente, a de que candidatos pentecostais receberiam mais recursos de partidos e/ou doadores com a expectativa de que esses candidatos converteriam mais facilmente (em comparação a outros) os recursos em votos. Note-se, pois, que as duas explicações aventadas supõem que candidatos pentecostais possuem um «custo de voto» comparativamente menor do que os dos outros candidatos - ou, no mínimo, um «custo de voto» que os torna candidatos competitivos para as eleições proporcionais brasileiras (ver tabela 5, abaixo).

Tabela 5. Relação gasto/voto (em R\$) nas eleições de 2014.

\begin{tabular}{lcc}
\hline \hline & Câmara & Assembleias \\
\hline Total de Candidatos & 13,15 & 14,21 \\
Evangélicos & 10,00 & 8,59 \\
Assembleia de Deus & 8,64 & 8,29 \\
Igreja do Evangelho Quadrangular & 8,36 & 9,00 \\
Igreja Universal do Reino de Deus & 4,57 & 3,79 \\
\hline \hline
\end{tabular}

Assim, uma primeira conjectura a ser testada é se candidatos pentecostais arrecadam (e, por extensão, gastam) mais ou menos do que os outros candidatos. Uma segunda conjectura diz respeito à diferença entre candidatos evangélicos e pentecostais. $\mathrm{O}$ apoio oficial de igrejas pentecostais é um recurso institucional que pode tornar os candidatos dessas igrejas mais competitivos, na medida em que diminui seu «custo de voto». Esse recurso deveria diferenciar candidatos oficiais pentecostais de candidatos evangélicos. Assim, é plausível supor que ser um candidato oficial pentecostal tem um efeito positivo sobre o número de votos, e que esse efeito é maior do que um eventual efeito de ser evangélico sobre os votos.

Conforme discutido na seção anterior, o apoio oficial de igreja pentecostal é um recurso relacionado ao perfil da igreja. Assim, uma terceira conjectura seria que igrejas com maior estrutura, centralização decisória e ênfase no apoio ao candidato produzam um efeito maior no 
desempenho eleitoral dos candidatos do que as outras (cf. Rodrigues e Fuks 2015). A partir desse raciocínio, apresento abaixo, de forma simplificada, as hipóteses a serem testadas.

Hipótese 1. Ser candidato pentecostal tem um efeito negativo sobre o gasto de campanha. Hipótese $2 a$. Ser candidato pentecostal tem um efeito positivo sobre o número de votos.

Hipótese $2 b$. Ser candidato pentecostal tem um efeito maior sobre o número de votos do que o de ser candidato evangélico.

Hipótese 3. Ser candidato pentecostal de uma igreja com maior estrutura, centralização decisória e ênfase no apoio tem um efeito maior sobre o número de votos do que ser candidato de outras igrejas.

\section{Dados}

Neste estudo, uso dados do Tribunal Superior Eleitoral (TSE) referentes às eleições para a Câmara dos Deputados e Assembleias estaduais brasileiras de 2014. A unidade de análise são os candidatos. O número total de candidatos para a Câmara foi de 4.942, e, para as Assembleias, 12.589. Uma primeira questão a ser levada em consideração diz respeito a quais candidatos devem ser incluídos na análise.

Usar todos os candidatos a deputado federal e estadual das eleições de 2014 implicaria em considerar na análise até mesmo aqueles candidatos pouco competitivos, que receberam poucos ou nenhum voto e poucos ou nenhum recurso para suas campanhas. Como observado por Samuels (2001a), a maior parte dos competidores nas eleições para os legislativos americano e brasileiro é em grande medida irrelevante. Porém, se fossem incluídos na análise, criariam um viés no sentido de aumentar a vantagem dos incumbentes, dado que os incumbentes estariam sendo comparados com todos os demais candidatos. Por isso, argumenta Samuels, apenas candidatos competitivos deveriam ser considerados ${ }^{67}$.

Mas o problema não decorre apenas do viés em favor dos incumbentes. O problema é mais geral e diz respeito a até que ponto certas observações devem influenciar a estimação dos parâmetros da regressão. Suponhamos dois candidatos, A e B. Ambos concorrem a uma vaga de deputado federal por São Paulo. O candidato A declarou gasto de campanha de 5 reais e obteve 10 votos. O candidato B, por sua vez, declarou gasto de 170 mil reais e obteve 12 mil votos. Em termos de sucesso eleitoral, é evidente que a relação entre gasto e voto do primeiro candidato (A) está distante da verdadeira relação entre gasto e voto no distrito em questão. Porém, se for incluído na análise, influenciará a estimação dos parâmetros.

\footnotetext{
${ }^{67}$ Por outro lado, outros autores que investigaram a relação entre gasto e voto no Brasil não seguiram essa recomendação e trabalharam com todos os candidatos, excluindo apenas aqueles que não declararam gasto nenhum ao TSE (e.g., Speck e Mancuso 2014; Lemos et al. 2010).
} 
Para contornar esse problema, optei por trabalhar com uma amostra contendo apenas aqueles candidatos que, em seu distrito, receberam $0.02 \%$ ou mais do total de votos válidos. Cabe lembrar que as eleições para o legislativo no Brasil são regidas pelo sistema de representação proporcional de lista aberta. Nesse sistema, os candidatos se elegem com percentuais muito inferiores ao que seria necessário numa disputa majoritária. Vale dizer, como exemplo, que os candidatos eleitos em 2014 com os menores percentuais de votos receberam $0.1 \%$ dos votos válidos para a Câmara e $0.12 \%$ para as Assembleias. O limite de $0.02 \%$ é, pois, bem inferior ao percentual mínimo de votos dos eleitos. Ele exclui um número considerável de candidatos não competitivos, mas não exclui nenhum candidato eleito e ainda permite a presença de um contingente expressivo de candidatos não eleitos. Vale dizer, por fim, que embora haja certa arbitrariedade ao estabelecer um limite de $0.02 \%$, seu único objetivo é retirar da amostra candidatos pouco competitivos e cuja inclusão poderia provocar algum viés nos resultados. Não haveria diferença, pois, se esse limite fosse um pouco superior ou inferior ao estipulado ${ }^{68}$.

Entre os candidatos para a Câmara, identifiquei 186 evangélicos. Desse número, 122 tiveram suas igrejas identificadas e 90 foram definidos como pentecostais. Entre os candidatos para as Assembleias, identifiquei 338 evangélicos, dos quais 156 tiveram as igrejas identificadas e 113 foram definidos como pentecostais. Para a amostra de candidatos competitivos, o número de evangélicos é menor, como mostram as tabelas 6 e 7, abaixo. No entanto, note-se que o número de pentecostais nas duas amostras é quase o mesmo, o que apenas indica que quase todos os candidatos pentecostais receberam um percentual igual ou maior que $0.02 \%$ de votos válidos em seus respectivos distritos.

Tabela 6. Número total de candidatos, evangélicos e pentecostais.

\begin{tabular}{lcccc}
\hline \hline Cargo & Total & Evangélicos & Igreja Identif. & Pentecostais \\
\hline Deputado Federal & 4942 & 186 & 122 & 90 \\
Deputado Estadual & 12589 & 338 & 156 & 113 \\
\hline \hline
\end{tabular}

Tabela 7. Amostra contendo apenas candidatos com $\geq 0.02 \%$ de votos.

\begin{tabular}{lcccc}
\hline \hline Cargo & Total & Evangélicos & Igreja Identif. & Pentecostais \\
\hline Deputado Federal & 3111 & 150 & 120 & 88 \\
Deputado Estadual & 7300 & 235 & 153 & 112 \\
\hline \hline
\end{tabular}

\footnotetext{
${ }^{68}$ Para confirmar isso, rodei modelos com todos os candidatos e modelos com um limite de $0.05 \%$. Encontrei pequenas diferenças na magnitude dos coeficientes, mas os sinais e a significância permaneceram iguais.
} 
O processo de identificação, seja dos candidatos, seja de suas igrejas, baseou-se em quatro estratégias distintas. Em primeiro lugar, no levantamento na literatura sobre evangélicos e eleições no Brasil, que oferece valiosas informações sobre políticos evangélicos. Em segundo lugar, nas informações contidas nos dados do TSE sobre a ocupação dos candidatos e sobre seus nomes de urna. Muitos candidatos evangélicos com cargos eclesiais declaram sua ocupação como «sacerdote ou membro de ordem ou seita religiosa». Além disso, muitos também usam títulos religiosos («bispo», «pastor», etc.) em seus nomes de urna. Em terceiro lugar, no contato direto com igrejas evangélicas. Poucas, porém, contribuíram para a pesquisa; a maioria ignorou meus pedidos de informações sobre quais candidatos apoiaram nas eleições. Em quarto e último lugar, na busca em jornais e sites de internet que especificassem a identidade religiosa e/ou a igreja à qual o candidato era ligado ${ }^{69}$. As variáveis usadas nos modelos deste estudo e suas descrições são detalhadas em seguida.

\section{Variáveis dependentes}

Gasto de campanha. Esta variável é dependente para o teste da primeira hipótese de pesquisa e independente para as demais hipóteses. Tal como visto na revisão da literatura, o gasto de campanha é um aspecto fundamental no desempenho eleitoral dos candidatos. No caso da análise dos candidatos pentecostais, é necessário investigar até que ponto eles arrecadam mais ou menos do que os demais candidatos. Assim como Lemos, Marcelino e Pederiva (2010) e Pereira e Rennó (2001), optei por definir esta variável como o logaritmo natural do gasto de campanha per capita. É, pois, a divisão do gasto absoluto de cada candidato pelo número de eleitores do distrito (em logaritmo). No entanto, decidi usar também o percentual de gasto, tal como o fizeram Samuels (2001a, 2002b) e Speck e Mancuso (2014). Trata-se do percentual, para cada candidato, do total dos gastos de campanha em determinado distrito. Desse modo, tem-se uma medida alternativa que, assim como no caso do gasto per capita, permite a comparação entre candidatos de diferentes distritos. As duas medidas possuem vantagens e desvantagens. $\mathrm{O}$ $\log$ do gasto per capita apresenta uma distribuição mais próxima da normal, ao passo que o percentual do gasto possui distribuição bastante assimétrica. Além disso, o percentual do gasto possui muitos outliers, o que não ocorre com o log do gasto per capita. No entanto, alguns modelos com o percentual de gasto apresentam um $\mathrm{R}^{2}$ maior, e os coeficientes das variáveis independentes de interesse são ligeiramente mais altos em modelos com o percentual do gasto.

Votos. Esta é a variável dependente que será usada no teste da maior parte das hipóteses, e que mede o desempenho eleitoral dos candidatos. De modo semelhante ao gasto de campanha,

${ }^{69}$ Para mais detalhes, ver capítulo anterior. 
optei por defini-la como o percentual de votos válidos que cada candidato recebeu em seu distrito. Uma outra possibilidade seria trabalhar com uma variável dependente binária que distinguiria os candidatos eleitos dos não eleitos. Embora haja bons argumentos para usar uma variável binária (ver, por exemplo, Speck e Mancuso 2014), meu objetivo neste estudo pode ser melhor atingido ao trabalhar com uma variável contínua.

O uso da variável binária acaba por desconsiderar que candidatos podem ter bons desempenhos mesmo se não forem eleitos. Nas eleições para os legislativos brasileiros, os melhores candidatos não-eleitos se tornam «suplentes», isto é, encabeçam uma lista daqueles que assumirão uma vaga se e quando os candidatos eleitos renunciarem a seus mandatos para assumir outros cargos. Seria difícil não considerar uma boa suplência como um bom desempenho eleitoral. Essa situação é adequadamente captada ao se trabalhar com uma variável contínua, mas não seria captada se se usasse uma variável binária ${ }^{70}$. Uma segunda justificativa para o uso do percentual de votos válidos em oposição às categorias 'eleito' e 'não-eleito' é que, nas eleições para o legislativo no Brasil, os candidatos não dependem apenas de si próprios. A possibilidade de coligações eleitorais em distritos de alta magnitude e com representação proporcional de lista aberta faz com que alguns candidatos recebam comparativamente menos votos, mas ainda assim sejam eleitos graças aos votos da coligação. Isso seria um problema se a variável fosse binária, mas não será um problema se a variável for contínua.

\section{Variáveis independentes}

Neste estudo, uso três variáveis independentes principais. São três variáveis binárias. A primeira e mais abrangente identifica se o candidato é ou não evangélico. A segunda e a mais importante, se o candidato possui ligação com uma igreja pentecostal. É, tecnicamente, uma proxy para identificar se o candidato é ou não apoiado por uma igreja pentecostal. A proxy é necessária porque nem sempre é possível distinguir os candidatos apoiados de fato por igrejas daqueles que, embora ligados a elas de alguma forma, não receberam apoio de fato ou oficial. Salvo raras exceções, as igrejas pentecostais não tornam públicas informações sobre o apoio a candidatos. A solução, então, é trabalhar com os candidatos ligados às igrejas, ainda que tal ligação nem sempre se traduza em apoio oficial. A tabela 8, abaixo, apresenta as igrejas pentecostais incluídas na variável e o número de candidatos ligados a elas.

Por fim, a terceira variável independente identifica se o candidato é ou não ligado à Igreja Universal do Reino de Deus. Ela será usada para testar a hipótese 3, isto é, se ser candidato pentecostal de uma igreja com maior estrutura, centralização decisória e ênfase no apoio tem um

\footnotetext{
${ }^{70}$ Tome-se, como exemplo, o caso da IURD no estado do Mato Grosso em 2006 (cf. Cuyabano 2009). A igreja lançou dois candidatos a deputado estadual e um a deputado federal. Nenhum deles foi eleito. Porém, todos obtiveram boas votações e, provavelmente, boas suplências (de fato, um deles foi o terceiro suplente).
} 
efeito maior sobre o número de votos do que ser candidato de outras igrejas. A IURD é a melhor escolha para isso, visto ser ela o maior exemplo identificado pela literatura de igreja pentecostal grande, com estrutura centralizada e de apoio enfático a seus candidatos. Cada uma dessas três variáveis - evangélico, pentecostal e membro da IURD - apresenta valor 1 quando os candidatos pertencem às categorias de interesse e 0 quando não pertencem.

Tabela 8. Candidatos pentecostais por igreja.

\begin{tabular}{lcc}
\hline \hline Igreja & Câmara & Assembleias \\
\hline Assembleia de Deus & 45 & 63 \\
Universal do Reino de Deus & 19 & 23 \\
Evangelho Quadrangular & 8 & 9 \\
Mundial do Poder de Deus & 4 & 9 \\
Internacional da Graça de Deus & 4 & 3 \\
Maranata & 3 & 2 \\
Sara Nossa Terra & 2 & 2 \\
Renascer em Cristo & 1 & 1 \\
Brasil Para Cristo & 1 & 0 \\
Nova Vida & 1 & 0 \\
TOTAL & 88 & 112 \\
\hline \hline
\end{tabular}

\section{Variáveis de controle}

Embora o argumento desenvolvido aqui esteja focado no impacto de ser candidato pentecostal sobre o gasto de campanha e sobre o desempenho eleitoral, outros fatores podem afetar essa relação. Um primeiro fator importante é o uso de título religioso. Muitos candidatos evangélicos e pentecostais usam títulos religiosos (pastor, bispo, missionário, etc.) em seus nomes de urna para atrair eleitores evangélicos. Como já argumentei, o uso de títulos religiosos não é aleatório, mas é mais usado por candidatos menos competitivos, presumivelmente para ativar sua identidade evangélica. A estratégia de foco eleitoral no grupo evangélico, mesmo perdendo votos entre os não-evangélicos (cf. Boas 2014), é racional num sistema de representação proporcional com lista aberta e alto número de competidores. Incluí nos modelos uma variável dummy para identificar os candidatos que usam títulos religiosos. Na disputa para a Câmara, 25\% dos candidatos pentecostais usaram títulos. No caso das Assembleias, esse percentual foi de $38,4 \%$.

$\mathrm{Na}$ literatura sobre as eleições para o legislativo, talvez o fator mais destacado para o desempenho eleitoral dos candidatos seja a incumbência. Como foi dito em seção anterior, 
Jacobson $(1978,1985,1990)$ argumentou sobre a diferença que o gasto de campanha pode ter no desempenho de incumbentes e desafiantes. No caso do Brasil, a discussão também existe. Samuels (2001a, 2001b) não encontrou diferença significativa entre os dois grupos, mas Speck e Mancuso (2014) e Lemos, Marcelino e Pederiva (2010) encontraram.

A importância da incumbência se justifica por duas suposições básicas que são, em alguma medida, relacionadas. A primeira é que candidatos incumbentes podem usar seus recursos ao longo do mandato para se tornarem conhecidos dos eleitores, o que os permitiria começar a campanha eleitoral à frente de seus rivais. A segunda é que incumbentes são candidatos presumivelmente mais fortes e com maior capital político, seja por seu carisma pessoal, seja por sua habilidade política, seja por outros fatores. Porém, no caso do Brasil, podese supor que muitos candidatos de maior capital político não pertençam necessariamente ao legislativo. É comum, por exemplo, que ex-prefeitos disputem vagas para deputado estadual e federal. O sistema político brasileiro oferece incentivos para que políticos não busquem construir carreiras necessariamente no legislativo (cf. Leoni et al. 2003). Cargos nos executivos municipais e estaduais podem ser mais interessantes do que uma cadeira numa Assembleia estadual ou mesmo na Câmara dos Deputados. Por conta disso, parece razoável levar em conta não apenas se os candidatos são incumbentes, senão também se já foram prefeitos. Assim, acrescentei aos modelos duas variáveis de controle dummy, uma para identificar os incumbentes, e outra para identificar aqueles candidatos que foram eleitos prefeitos em 2004 e/ou 2008. Pouco mais de um terço dos candidatos pentecostais concorrendo em 2014 eram incumbentes, mas apenas dois deles eram ex-prefeitos.

Outro fator importante a se considerar é o desempenho nas últimas eleições. É verdade que, do total de candidatos analisados, apenas uma pequena fração corresponde a candidatos buscando a reeleição. A maioria não disputou as eleições anteriores. No entanto, é possível usar como controle o desempenho dos partidos dos candidatos nas últimas eleições. Esse fator pode dar conta de manter constantes as preferências dos eleitores nos respectivos distritos. Assim, incluo como controle uma variável com o percentual de votos no partido para as eleições de 2010. Os percentuais se referem às eleições para a Câmara, no caso de candidatos a deputado federal, e para as Assembleias, no caso de candidatos a deputado estadual. Vale frisar que a maioria dos estudos sobre a relação entre gasto e voto nas eleições para o Congresso americano usa algum tipo de controle para a preferência da constituency (cf. Stratman 2005) ${ }^{71}$.

A literatura sobre o caso brasileiro destaca também outro fator relevante, a saber, a pertença do partido do candidato ao governo federal (cf. Pereira e Rennó 2001, 2007; Leoni et al. 2003). A suposição é que candidatos se beneficiariam de pertencer à coalizão do governo federal,

\footnotetext{
${ }^{71}$ No caso de candidatos de partidos cujo registro foi obtido após 2010, como o Partido Ecológico Nacional (PEN), o Partido Republicano da Ordem Social (PROS) e o Solidariedade (SD), o valor atribuído foi zero.
} 
seja pelos benefícios que a pertença poderia conceder a seus mandatos no caso de candidatos à reeleição, seja por um possível efeito coattail que poderia beneficiar os candidatos ligados à base do governo ${ }^{72}$. O raciocínio poderia valer também para os governos estaduais, dado o suposto poder que governadores brasileiros teriam sobre lideranças políticas estaduais e municipais (cf. Abrúcio 1998). No entanto, como argumentam Pereira e Rennó (2007), as mudanças institucionais ocorridas ao longo da década de 1990, tais como o fim dos bancos estaduais e a aprovação da Lei de Responsabilidade Fiscal, diminuíram o poder dos governos estaduais, tornando sua influência menos certa. Assim, incluí nos modelos apenas uma variável dummy para controlar pela pertença à coligação do governo federal em 2014.

Outro fator levantado pela literatura e que merece atenção é o dos partidos. No debate sobre a relação entre gasto e voto nas eleições para o Congresso americano, os modelos incorporam variáveis especificando os partidos dos candidatos (e.g., Jacobson 1978; Green e Krasno 1988). No entanto, nem todos os estudos sobre o caso brasileiro usam os partidos como controles. A relevância do partido depende, é claro, do que se quer investigar. No caso da relação entre gasto e voto, parece plausível supor que o partido político do candidato seja uma variável relacionada tanto ao gasto, quanto ao voto, e que, por isso, deveria ser incorporada. No entanto, o foco deste estudo não é propriamente a relação entre gasto e voto, e sim entre ser candidato oficial pentecostal e voto.

É razoável supor que o desempenho dos candidatos pentecostais dependa pouco dos partidos. A literatura costuma caracterizar os partidos brasileiros como fracos e com «marcas» diluídas. As exceções seriam o PT e, em menor medida, o PSDB e o PMDB. No entanto, como mostra a tabela 9, abaixo, os candidatos pentecostais tendem a se pulverizar em partidos pequenos, comparativamente pouco estruturados e com ideologia difusa. São, em geral, partidos de centro ou centro-direita, mas cuja «marca» sinaliza pouco aos eleitores. Além disso, os partidos que abrigam candidatos pentecostais provavelmente contribuem menos para as campanhas de seus candidatos do que partidos mais fortes, como PT e PSDB. A caracterização do candidato pentecostal feita pela literatura sugere implicitamente que eles sejam pouco dependentes de seus partidos, já que, em tese, poderiam contar com seus «rebanhos eleitorais». Esses argumentos poderiam justificar a exclusão dos partidos dos modelos estatísticos deste estudo. No entanto, com base na Tabela 9, optei por incluir dummies apenas para os partidos com maior concentração de candidatos pentecostais, quais sejam: PRB e PSC.

\footnotetext{
${ }^{72}$ Vale lembrar que, a despeito da queda na popularidade da presidente Dilma Rousseff entre março e junho de 2013, ela terminou o ano de 2014 com níveis de aprovação relativamente altos. Ver, por exemplo: "Popularidade de Dilma Rousseff aumenta e 52\% aprovam a maneira de governar da presidente" (Agência de Notícias CNI, 17/12/14).
} 
Tabela 9. Candidatos pentecostais por partido.

\begin{tabular}{ccc}
\hline \hline $\begin{array}{c}\text { No. de } \\
\text { Candidatos }\end{array}$ & Câmara & Assembleias \\
\hline \multirow{2}{*}{1} & PMN, PPS, PROS, & PMN, PP, PPS, PSDC, \\
& $\begin{array}{c}\text { PSDC, PTC, PTN, PV } \\
\text { PDT, PEN, PP, PRP, }\end{array}$ & PSL \\
2 & PRTB, PTdoB, PHS, & SD \\
& PSB & \\
3 & PSD, PSDB, SD & PDT, PHS, PTC \\
& & PEN, PRP, PSB, \\
4 a 6 & DEM, PMDB, PR, & PSDB, PTB, PTN, \\
7 a 10 & PTB & DEM, PR, PROS \\
11 a 15 & - & PMDB \\
16 a 20 & PSC & PSD \\
21 a 25 & - & PSC \\
\hline \hline
\end{tabular}

Por fim, acrescento aos modelos variáveis de controle para gênero, raça e idade. As duas primeiras são dummies e a última é contínua. No caso de gênero, a variável assume valor 1 para mulheres e 0 para homens. No caso de raça, assume 1 para negros ou pardos, e 0 para os demais. Vale dizer que, nas eleições de 2014 para a Câmara e Assembleias, um quarto do total de candidatos era mulher. No caso dos candidatos pentecostais, essa proporção diminui para um décimo. Em outras palavras, se, no conjunto total de candidatos, um em cada quatro era mulher, dentro do subconjunto de pentecostais as mulheres representam apenas um em cada dez. No que se refere à raça, a proporção de negros + pardos no total de candidatos é semelhante à encontrada no subconjunto de candidatos pentecostais (pouco menos de $40 \%$ em ambos os grupos). A subrepresentação de mulheres e afro-brasileiros no legislativo brasileiro, bem como seu menor potencial de arrecadação de campanha (cf. Sacchet e Speck 2012), sugere a importância da inclusão de controles para gênero e raça nos modelos.

\section{Resultados}

De modo a testar as hipóteses enunciadas anteriormente, uso regressões OLS para estimar seis modelos, replicados para a Câmara e as Assembleias. Os coeficientes das principais 
variáveis de interesse são apresentados nos gráficos abaixo (as tabelas com os modelos completos se encontram no Apêndice A). Os modelos 1 e 2 são usados para testar a primeira hipótese, segundo a qual ser candidato pentecostal teria um impacto negativo sobre o gasto de campanha. A variável dependente do modelo 1 é o logaritmo natural do gasto per capita, e a do modelo 2, o percentual do gasto. Os modelos 3 e 4 dizem respeito à segunda hipótese, segundo a qual (a) ser candidato pentecostal teria um efeito positivo sobre o número de votos, bem como (b) um efeito maior do que o de ser evangélico. A variável dependente de ambos é o percentual de votos. A única diferença entre eles é a especificação da variável independente de gasto de campanha (o modelo 3 usa o gasto per capita e o modelo 4, o percentual do gasto). Por fim, os modelos 5 e 6 são usados para testar a terceira hipótese, segundo a qual ser candidato pentecostal de uma igreja com maior estrutura, centralização decisória e ênfase no apoio produziria um efeito maior sobre o número de votos do que ser candidato de outras igrejas. Mais uma vez, a variável dependente de ambos é o percentual de votos, e a única diferença entre eles é a especificação do gasto de campanha (o modelo 5 usa o gasto per capita e o modelo 6, o percentual do gasto). Cada um dos modelos é apresentado em duas versões, uma para a Câmara, outra para as Assembleias.

FIGURA 13. Efeito de ser pentecostal sobre o gasto

Câmara

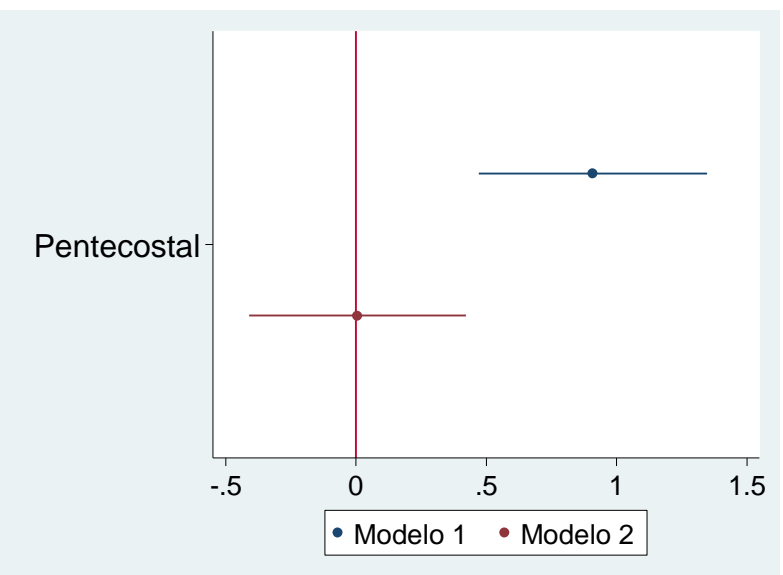

Assembleias

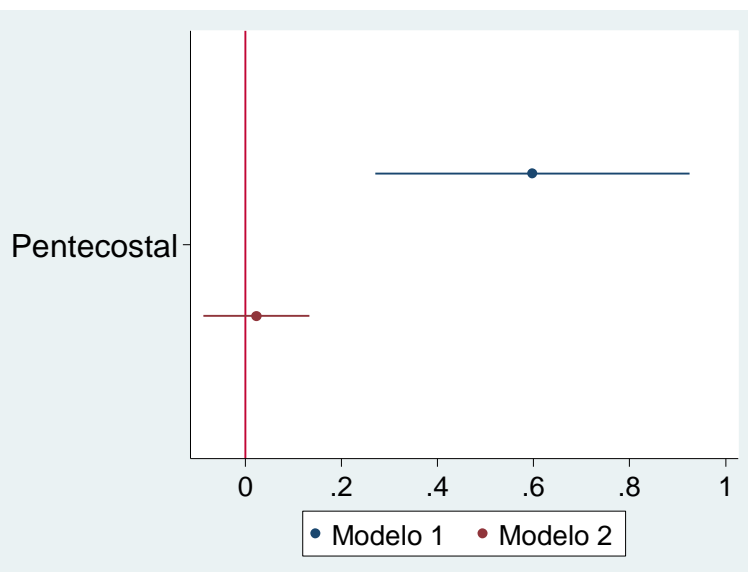

Nota: as linhas representam intervalos de confiança de $95 \%$. 
FIGURA 14. Efeito de ser evangélico ou pentecostal sobre o voto

Câmara

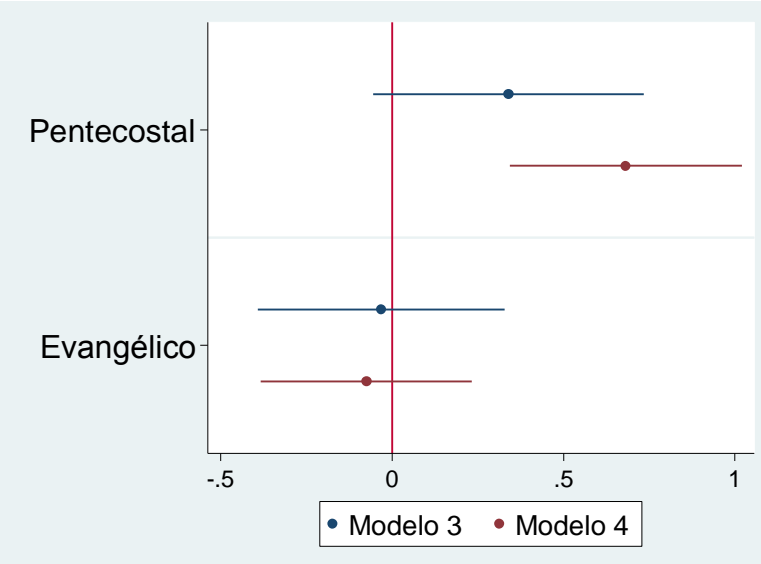

Assembleias

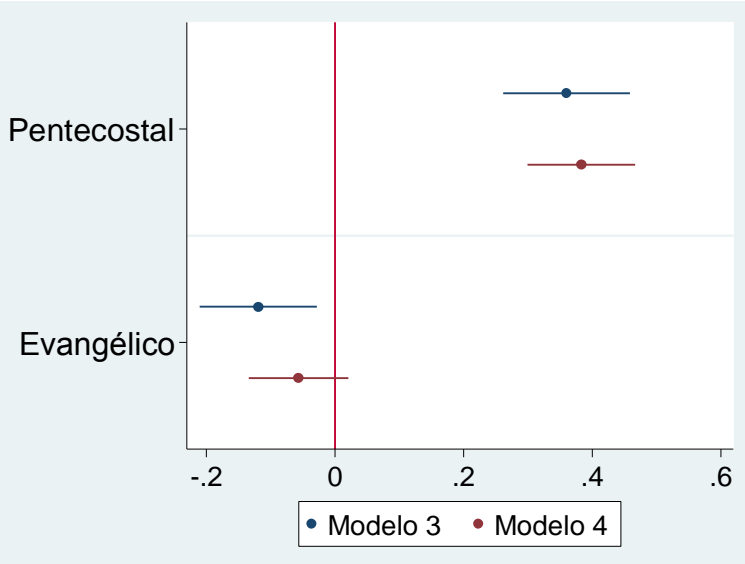

Nota: as linhas representam intervalos de confiança de $95 \%$.

FIGURA 15. Efeito de ser apoiado pela IURD sobre o voto

Câmara

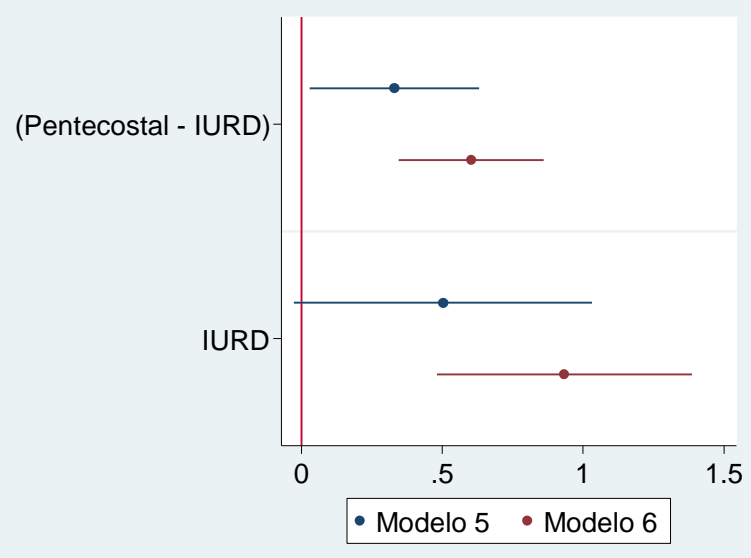

Assembleias

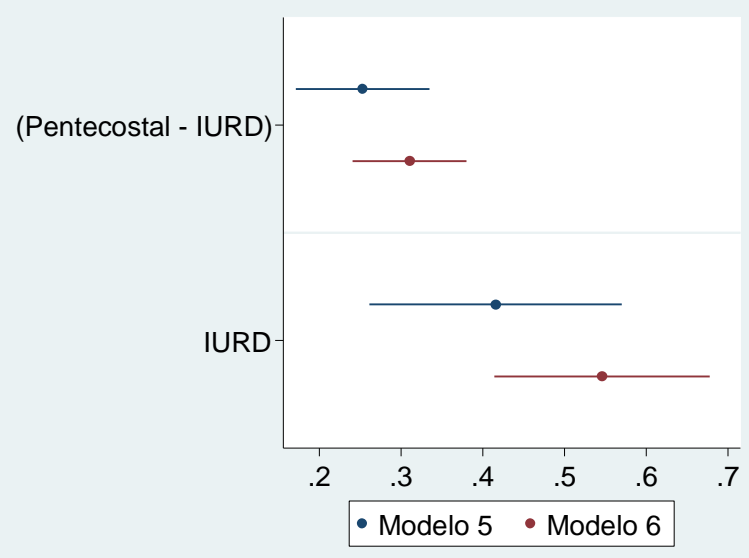

Nota: as linhas representam intervalos de confiança de $95 \%$. 
A primeira hipótese não é confirmada pelos modelos 1 e 2. Para ambos, a variável principal é 'Pentecostal', que especifica se o candidato é ou não apoiado por uma igreja pentecostal. Os resultados diferem de acordo com a variável dependente adotada, mas nenhum deles sugere um efeito negativo de ser pentecostal sobre o gasto. Pelo contrário: os modelos apontam para uma relação positiva entre ser pentecostal e gasto de campanha, mesmo a despeito de todos os controles. Adotando o log do gasto per capita, a relação é positiva e estatisticamente significativa (ao nível 0.01) tanto nas eleições para a Câmara quanto para as Assembleias. Porém, ela perde a significância ao se adotar o percentual do gasto, ainda que se mantenha positiva. Assim, embora dependam da especificação dos modelos, os resultados sugerem uma relação positiva entre ser candidato pentecostal e gasto.

A segunda hipótese encontra apoio nos modelos 3 e 4 . Nesse caso, as variáveis de maior interesse são 'Pentecostal' e 'Evangélico'. Com relação à hipótese 2.a, há um efeito positivo e com significância estatística (quase sempre ao nível 0.01) de ser pentecostal sobre o \% de votos para todos os modelos. O efeito se mantém mesmo se controlado pelos efeitos da incumbência, pelo desempenho do partido do candidato nas eleições anteriores (2010), pela pertença à coalizão do governo federal, por gênero, raça e idade, pelo uso de título religioso e até mesmo controlando pelo efeito dos partidos com maior número de candidatos pentecostais - PRB e PSC. No modelo 3, que usa o logaritmo natural do gasto per capita, o efeito de ser pentecostal diminui em comparação ao modelo 4, mas ainda assim é positivo e com significância para a Câmara (ao nível 0.1) e para as Assembleias (ao nível 0.01).

A hipótese 2.b supõe a comparação entre os coeficientes de 'Pentecostal' e 'Evangélico'. A figura 14 revela que, para quase todos os casos, os intervalos de confiança dos coeficientes não se sobrepõem, indicando que a diferença entre eles é estatisticamente significativa ${ }^{73}$. A exceção é a comparação entre os dois coeficientes no modelo 3 da Câmara dos Deputados. Um teste Wald revela que a hipótese de que os dois coeficientes do modelo são diferentes não pode ser rejeitada para nenhum nível de significância abaixo de 30\% (Prob > F = 0.2996), o que significa que ela provavelmente não pode ser rejeitada ${ }^{74}$. Ainda assim, os resultados parecem corroborar a conjectura de que o efeito de ser candidato pentecostal é diferente do de ser evangélico.

A terceira hipótese, testada com os modelos 5 e 6, afirma que o tipo da igreja tem relevância no efeito de ser candidato pentecostal. Uma igreja com maior estrutura, centralização decisória e ênfase no apoio geraria um efeito maior sobre os votos do candidato do que outras igrejas. Para testar essa conjectura, optei por uma comparação entre o efeito de ser pentecostal e o efeito de ser apoiado pela IURD. Para essa comparação, criei uma nova variável, 'Pentecostal -

\footnotetext{
73 Ver «Overlapping Confidence Intervals and Statistical Significance» (StatNews \#73, 10/2008). Disponível em: <https://www.cscu.cornell.edu/news/statnews/stnews73.pdf> (acessado pela última vez em 2/01/17).

${ }^{74}$ Todos os testes Wald foram feitos com o comando de pós-estimação do Stata 12.
} 
IURD', que é, como o nome sugere, a mesma variável 'Pentecostal', porém sem os candidatos pertencentes à IURD. A razão é que, sem isso, não é possível obter um coeficiente para a variável 'IURD' ${ }^{75}$.

O coeficiente de 'IURD' é consideravelmente maior do que o de 'Pentecostal - IURD'. No entanto, apenas no modelo 6 das Assembleias os intervalos de confiança dos coeficientes não se sobrepõem. O teste Wald para o modelo 5 das Assembleias revela que a hipótese de diferença entre os coeficientes não pode ser rejeitada a um nível de significância de 5\%, mas pode sê-lo a um de 10\% (Prob > F = 0.0601). Porém, para o modelos da Câmara, a hipótese de os dois coeficientes serem diferentes não pode ser rejeitada para nenhum nível de significância abaixo de $57 \%$ (modelo 5) e 20.56\% (modelo 6). Assim, parece razoável afirmar que, no caso da hipótese 3, o efeito de ser um candidato apoiado pela IURD é maior do que o de ser apoiado por outras igrejas, mas a diferença entre os efeitos só apresenta significância estatística nos modelos para as Assembleias.

Por fim, vale mencionar que os resultados dos coeficientes das variáveis de controle para a Câmara e as Assembleias foram semelhantes. Para todos os modelos, o efeito do gasto de campanha (seja como percentual, seja como logaritmo do gasto per capita) foi positivo e significativo. $\mathrm{O}$ mesmo vale para os efeitos de incumbência e de ser ex-prefeito. O percentual de votos do partido na última eleição tem efeito positivo e significativo, porém quase nulo, para todos os modelos da Câmara, mas é quase igual a zero para os modelos das Assembleias. A pertença à coalizão federal tem efeito positivo e com significância estatística para Câmara e Assembleias, mas apenas quando a variável dependente é o gasto de campanha. Por último, vale mencionar que o efeito de ser mulher é, em geral, negativo e com significância estatística, ao passo de que o de ser afro-brasileiro é em geral negativo, mas próximo de zero e nem sempre significativo.

\section{Evidências qualitativas}

Poderia ser objetado que não estou medindo o apoio das igrejas enquanto recurso institucional, e sim certas habilidades (adquiridas ou inatas) dos candidatos pentecostais, tais como carisma pessoal, capital social, etc. Talvez o efeito identificado de ser candidato pentecostal sobre o voto, a despeito de todos os controles utilizados nos modelos de regressão, revele, na verdade, certas capacidades desses candidatos que não estariam sendo devidamente controladas. Talvez sejam as mesmas capacidades que fizeram com que eles ascendessem nas hierarquias de suas igrejas, por exemplo. Não nego que haja fatores relacionados a esses candidatos que não foram controlados nos modelos apresentados anteriormente. No entanto,

\footnotetext{
${ }^{75}$ Optei também por não incluir controles para PRB e pertença à coalizão federal pelo simples fato de que todos os candidatos da IURD pertenciam ao PRB, e o PRB, por sua vez, pertencia à coalizão federal.
} 
argumentarei aqui que, em que pesem as supostas habilidades dos candidatos pentecostais, seu desempenho eleitoral se deve em larga medida ao apoio das igrejas, e que o efeito de ser pentecostal sobre o voto diminui ou desaparece quando o apoio da igreja está ausente.

Para isso, ofereço, nesta seção, evidências qualitativas de seis candidatos pentecostais que foram eleitos com o apoio de suas igrejas, mas que romperam com elas ao longo do mandato e, mesmo assim, tentaram a reeleição. Essas evidências podem servir como uma base contrafactual para se pensar em qual seria o desempenho desses candidatos caso estivesse ausente o apoio da igreja. Cada um deles teve um declínio acentuado em seu número de votos e nenhum deles se reelegeu. Até onde sei, esses são os únicos casos de políticos pentecostais que romperam com a igreja ao longo do mandato. Não há, pois, salvo engano, casos que tenham resultado em desempenho eleitoral igual ou melhor.

Magaly Machado. Em 1998, Machado foi eleita deputada estadual pelo PFL-RJ com o apoio da IURD. Ela recebeu 33.678 votos (0.47\% dos votos válidos). Em 2002, deixou de ser candidata da Universal e passou a contar com o apoio da Igreja Nova Vida. Mesmo assim, disputou pelo PSB-RJ uma vaga para deputado federal. Ela recebeu 9.418 votos $(0.12 \%)$ e não foi eleita ${ }^{76}$.

Heriberto da Silva Farias. Em 1998, «Pastor Heriberto» (PMDB) foi eleito deputado estadual no Ceará com o apoio da IURD. O candidato obteve 43.904 votos, ou $1.61 \%$ dos votos válidos. Porém, em 2002, concorreu à reeleição pelo PL e sem o apoio da igreja. O pastor não se reelegeu, obtendo apenas 1.338 votos $(0.04 \%)^{77}$.

Paulo Cesar de Velasco. De Velasco (PRONA), candidato apoiado pela IURD, foi eleito deputado federal por São Paulo em 1998, tendo recebido 94.880 votos $(0.61 \%$ dos votos válidos). Não há evidências precisas de data ou circunstância, mas, em algum momento durante seu mandato, o político teria rompido com a IURD ${ }^{78}$. Em 2002, decidiu concorrer a uma vaga para deputado estadual pelo PSL, e, dessa vez, conseguiu apenas 2.158 votos $(0.01 \%)$.

Nataniel Nazareno Ferreira. Conhecido como «Nataniel de Jesus» (PMDB), o candidato foi eleito deputado estadual por Mato Grosso em 2002 e recebeu 12.848 votos, ou $1.0 \%$ dos votos válidos. Era candidato oficial da IURD ${ }^{79}$. O deputado foi expulso da igreja, mas, mesmo assim, tentou a reeleição em 2006. Seu desempenho foi bastante inferior ao do pleito anterior e acabou não se reelegendo: conseguiu apenas 4.286 votos, ou $0.3 \%$ dos votos válidos.

Denílson Segóvia. Em 2010, «Pastor Denílson» (PSC) foi eleito deputado estadual pelo Acre com o apoio oficial da IEQ, da qual era pastor e presidente estadual. O candidato obteve

\footnotetext{
${ }^{76}$ Ver Oro (2003b).

${ }^{77}$ Idem.

${ }^{78}$ Ver Souza (2009).

${ }^{79}$ Ver Cuyabano (2009).
} 
2.939 votos. Porém, segundo noticiado pela mídia, Segóvia foi expulso da igreja em $2013^{80}$. Em 2014, buscou a reeleição pelo PEN, mas obteve apenas 1.133 votos $(0.28 \%)$ e não foi bemsucedido.

Zacarias Vilharba. Em 2010, o candidato «Vilalba de Jesus» (PRB) disputou uma vaga para deputado federal por Pernambuco. Contava com o apoio da IURD. Embora não tenha sido eleito, obteve a segunda suplência e uma expressiva votação de 39.173 votos. Em 2014, o candidato buscou a reeleição sem o apoio da igreja ${ }^{81}$. Migrou para o PP e mudou seu nome de urna para «Pastor Vilalba». O desempenho do pastor foi bastante inferior ao do pleito anterior, obtendo 11.199 votos $(0.25 \%)$, o que não lhe garantiu nem a eleição, nem uma boa suplência.

\section{Conclusões}

De acordo com parte da literatura sobre crescimento pentecostal e política na América Latina, a entrada de igrejas pentecostais na política seria prejudicial à democracia. Por terem o controle sobre os votos de suas congregações, líderes pentecostais poderiam se eleger (ou eleger outros candidatos) para o legislativo, beneficiando, então, suas igrejas com políticas paroquiais. Tal argumento se assenta na suposição de que líderes pentecostais obteriam considerável grau de apoio de suas igrejas.

Este trabalho contribui para uma melhor compreensão da relação entre igrejas, candidatos e eleições para o legislativo no Brasil. A partir de novos dados, ofereço evidências quantitativas importantes para avaliar o argumento acima e outros da literatura sobre pentecostalismo e política. É o primeiro trabalho a usar dados de identificação de candidatos evangélicos que não apenas os baseados em títulos religiosos e «nomes de urna». Como se viu, o uso de títulos religiosos é um recurso usado sobretudo por candidatos pouco competitivos. A maior parte dos candidatos pentecostais competitivos prescinde desse recurso, o que indica que a identificação de candidatos pentecostais apenas por meio dos «nomes de urna» levará necessariamente a modelos enviesados.

O exame da literatura deixou clara a importância de se investigar a relação entre o gasto de campanha e o desempenho nas eleições. Argumentei que, de um ponto de vista teórico, era plausível supor que candidatos pentecostais poderiam apresentar um gasto de campanha maior ou menor do que os demais candidatos. Mostrei, então, que pentecostais das igrejas Assembleia de Deus, Evangelho Quadrangular e Universal têm um «custo de voto» comparativamente menor do que o dos outros candidatos, sendo o «custo de voto» da Universal consideravelmente menor que o das outras igrejas. $\mathrm{O}$ voto dos candidatos pentecostais custa menos do que os outros, e o dos candidatos da IURD custa menos do que o dos pentecostais.

\footnotetext{
${ }^{80}$ Ver «Denílson Segóvia é destituído da presidência da Igreja Quadrangular» (AC24Horas, 21/10/13).

${ }^{81}$ Ver «Vilalba vai à reeleição, mas sem apoio da Igreja Universal» (Inaldo Sampaio - CBN, 5/05/14).
} 
Por meio de modelos de regressão OLS, procurei testar se haveria uma relação negativa entre ser candidato pentecostal e gasto de campanha. Os modelos não permitem uma afirmação categórica, mas apontam para a direção contrária. Se a variável dependente utilizada for o log do gasto per capita, então há uma relação positiva e estatisticamente significativa entre ser pentecostal e gasto. Ceteris paribus, ser pentecostal faz com que um candidato receba mais dinheiro. No entanto, se a variável dependente escolhida for o percentual do gasto, o efeito deixa de ser significativo.

Em seguida, investiguei se haveria um efeito de ser pentecostal sobre o voto, e se tal efeito seria superior ao de ser candidato evangélico. Os resultados parecem confirmar as duas conjecturas, ainda que, no caso da Câmara dos Deputados, a diferença entre o efeito de ser pentecostal e o de ser evangélico seja estatisticamente significativa apenas no modelo 4, que usa o percentual do gasto como variável independente. Vale frisar que o efeito de ser pentecostal se mantém mesmo controlando por fatores como incumbência, gasto, desempenho do partido na eleição anterior, pertença à coalizão federal, gênero, raça, idade e pertença aos partidos PRB e PSC. É, pois, uma forte evidência a confirmar a conjectura de que o apoio das igrejas pentecostais contribui de modo significativo para o desempenho eleitoral do candidato. Para reforçar meu argumento, ofereci na seção 6 evidências qualitativas para um raciocínio contrafactual: qual seria o desempenho dos candidatos pentecostais, estivesse ausente o apoio da igreja? Entre 1998 e 2014, houve pelo menos seis casos de candidatos pentecostais que, eleitos com o apoio de suas igrejas, romperam com elas ao longo do mandato, e, mesmo assim, decidiram concorrer à reeleição. Todos eles tiveram desempenhos consideravelmente inferiores e não se reelegeram.

É importante frisar também que, mantendo o efeito de ser pentecostal constante, o efeito de ser evangélico sobre o voto é negativo tanto para a Câmara quanto para as Assembleias embora em geral sem significância estatística. Esse resultado é intuitivo e pode indicar que, controlando pelo efeito de ser apoiado por uma igreja pentecostal, ser evangélico não traz necessariamente nenhum benefício eleitoral ao candidato.

Por meio dos modelos 5 e 6, procurei testar também se o tipo e estrutura da igreja importam no apoio aos candidatos. Para isso, investiguei se o efeito de ser apoiado pela IURD seria maior do que o efeito de ser pentecostal. $O$ efeito é, de fato, maior, ainda que a diferença entre eles seja estatisticamente significativa apenas nos testes para as Assembleias. O baixo número de candidatos da IURD faz com que o erro padrão do coeficiente seja alto. Mesmo assim, o conjunto de evidência reunidos aqui vai ao encontro da conjectura de que igrejas com maior estrutura e centralização contribuem mais para o desempenho eleitoral de seus candidatos do que as demais, além de terem um «custo de voto» menor. 
Cabe observar que os resultados apresentados aqui se baseiam apenas na eleição de 2014 . Isso implica que, por mais fortes que sejam, têm um poder de generalização limitado. Novas pesquisas devem refazer esses testes com novas eleições e, se possível, também para os legislativos municipais.

Por fim, faço menção a uma última possível objeção, relacionada à anterior. É a de que as eleições brasileiras de 2014 teriam sido marcadas por um «crescimento conservador» ${ }^{82}$, e que, por isso, o efeito do apoio das igrejas pentecostais teria sido mais forte nessas eleições do que em outras. Em primeiro lugar, cabe notar que juízos de maior «conservadorismo» no Congresso eleito em 2014 são comuns na mídia, mas, pelo menos até o momento, carecem de maior base acadêmica. Os poucos trabalhos realizados até hoje sobre o tema trazem evidências que não necessariamente apoiam a ideia de um crescimento conservador (e.g., Santos e Canello 2015).

Em segundo lugar, tais juízos são baseados em análises dos candidatos eleitos e ignoram os não-eleitos. Ocorre que, como já foi mostrado neste trabalho, o número relativo de candidaturas evangélicas vem se mantendo estável desde 2002 (cf. Capítulo 2). Ao mesmo tempo, a população evangélica vem crescendo, o que torna até certo ponto esperado o crescimento no número de evangélicos eleitos. Apesar disso, grandes igrejas pentecostais, como a Igreja Universal e a Igreja do Evangelho Quadrangular, não cresceram em 2014 (idem). Isso sem falar que, a despeito do crescimento da população evangélica, em 2014 foram eleitos para a Câmara apenas dois candidatos evangélicos a mais do que em 2010 (67 em 2014 contra 65 em 2010). Essas evidências vão de encontro à ideia de que as eleições de 2014 teriam sido singulares ou significativamente mais «conservadoras» do que as anteriores. É certo que as conclusões deste trabalho terão a ganhar com estudos que se debrucem sobre outras eleições, mas tal observação não invalida os resultados encontrados aqui.

\footnotetext{
${ }^{82}$ Ver, por exemplo, «Congresso eleito é o mais conservador desde 1964, afirma DIAP» (Estadão, 6/10/14).
} 


\section{Capítulo 4}

\section{Pistas Religiosas, Oferta de Candidatos e Escolha Eleitoral para o Legislativo no Brasil}

\section{Introdução}

Desde a constituição da República até a década de 1970, o «mercado» religioso brasileiro manteve a hegemonia do catolicismo sobre as demais religiões. A variação percentual do número de católicos em um século, de 1870 a 1970, foi de menos de 8\%, caindo de 99,7\% para 91,8\% (cf. Censo Demográfico 2010). O perfil hegemônico da religião católica era tal que clivagens baseadas em religião tiveram historicamente pouca relevância em termos político-eleitorais. Desde o final do século XIX, evangélicos já estavam presentes no Brasil, mas seu tamanho relativo na população era diminuto. O declínio da população católica na primeira metade do século XX se acentuou a partir das décadas de 1970 e 1980, e o perfil religioso da população brasileira nos anos 2000, conquanto ainda majoritariamente católico, era nitidamente distinto. O Censo 2010 registrou a acentuada queda de católicos, que chegaram a 64,6\% da população, e o crescimento de diferentes grupos religiosos, sobretudo evangélicos $(22,2 \%)$ e sem religião (8\%). Já no final da década de 1980, mas hoje ainda com mais força, fazem-se sentir algumas consequências políticas e eleitorais dessas mudanças. Uma delas é a maior visibilidade de candidatos e políticos evangélicos.

Desde 1945, o Brasil adota o sistema eleitoral de representação proporcional de lista aberta. Para a eleição de deputados federais e estaduais, o distrito eleitoral é o estado, cujo número de cadeiras, no caso da Câmara dos Deputados, varia de oito (caso de Acre e Rondônia, por exemplo) a 70 (caso de São Paulo). Para a eleição de vereadores, o distrito é o município. Mesmo nesse caso, o número de cadeiras em disputa pode variar de nove, para aqueles com até 15 mil habitantes, a 55 cadeiras, para aqueles com mais de oito milhões. A representação proporcional com lista aberta e alto número de cadeiras contribui para que, no Brasil, as eleições para o legislativo sejam disputadas por grande número de candidatos, e que um candidato possa ser eleito com um percentual relativamente baixo do total de votos válidos.

Desde a redemocratização, um número cada vez mais visível de candidatos evangélicos passou a disputar as eleições para os legislativos brasileiros. Dados os incentivos da competição eleitoral brasileira, muitos deles buscaram tornar explícita sua identidade evangélica, com o 
objetivo de ganhar voto entre o eleitorado evangélico que, como se viu, vem crescendo de modo acentuado. Pesquisas anteriores (cf. Boas 2014) apresentaram evidências de que eleitores evangélicos teriam maior inclinação a votar em candidatos evangélicos para o legislativo. A identidade social ativaria algum tipo de discriminação em prol do próprio grupo e/ou contra os grupos (cf. Tajfel e Turner 1979). Além disso, as pistas informacionais utilizadas por candidatos (i.e., informações sobre seu pertencimento a certo grupo social, étnico ou religioso) seriam usadas pelos eleitores como recursos heurísticos (cf. McDermott 2009; Sniderman et al. 1991), particularmente importantes em ambientes eleitorais complexos e de alto custo cognitivo (Cunow 2014).

Neste trabalho, apresentamos os resultados de um experimento de survey realizado com 730 estudantes de universidades privadas da cidade de São Paulo, durante as eleições municipais de 2016. Seu objetivo é identificar o efeito que pistas religiosas utilizadas por candidatos evangélicos podem ter sobre os eleitores. Os participantes do experimento receberam informações sobre candidatos a vereador pela cidade de São Paulo, dos quais deveriam escolher um. Para aqueles atribuídos aos grupos de tratamento, um dos candidatos se apresentava como pastor ou pertencente a alguma igreja evangélica pentecostal. Além disso, manipulamos também a oferta de candidatos, de modo a testar se haveria alguma relação entre a escolha do candidato e o número de candidatos ofertados.

\section{Revisão da literatura}

As eleições legislativas brasileiras costumam ser caracterizadas pela literatura como de alta complexidade para os eleitores (Cunow 2014). A disputa eleitoral para o pleito legislativo é regida pelo sistema de representação proporcional de lista aberta. Os distritos têm alta magnitude: no caso da disputa para a Câmara dos Deputados e para as Assembleias estaduais, os distritos são os próprios estados; no caso da Câmara Municipal, é o próprio município. O número de cadeiras das Câmaras Municipais está condicionado ao tamanho da população municipal, podendo variar de nove, para municípios com até 15 mil habitantes, a 55 cadeiras para municípios com mais de oito milhões. No caso da cidade de São Paulo, cuja Câmara possui 55 cadeiras, a eleição de 2016 envolveu a disputa entre dezenas de candidatos incumbentes e mais de mil desafiantes.

Além da alta magnitude dos distritos e do alto número de candidatos, outro aspecto que pode aumentar o custo cognitivo das eleições legislativas brasileiras é a alta fragmentação do sistema político, uma das maiores do mundo (Clark, Gilligan e Goulder 2006), e, de modo relacionado, a baixa diferenciação das «marcas» partidárias (Power e Zucco 2009). A identidade entre partidos e eleitores é consideravelmente baixa (Mainwaring, 2001; Kinzo, 2005; Paiva e Tarouco, 2011). A representação proporcional de lista aberta incentivaria os candidatos a 
centrarem suas campanhas em si mesmos e não em sua agremiação partidária. Por fim, o Brasil é uma nova democracia com um sistema partidário recente - nenhum dos partidos brasileiros existia antes da década de 1980. Nesse cenário, é plausível supor que eleitores procurem «atalhos» informacionais para escolher seus candidatos. Um desses «atalhos» seria a identificação entre os candidatos e grupos sociais ${ }^{83}$.

Um dos desdobramentos do debate sobre a identidade partidária na ciência política americana, particularmente dentro da perspectiva sócio-psicológica do voto, foi a da relação entre identidade partidária e grupos sociais. Para Campbell, Converse, Miller e Stokes (1960), autores do clássico The American Voter, eleitores frequentemente se vêem a si mesmos como pertencendo a grupos partidários, tais como democratas ou republicanos. $\mathrm{O}$ grupo existiria como um estereótipo na mente do eleitor, que pode se vincular ou não a ele. Tal ideia explicaria por que eleitores céticos em relação a partidos e com poucas informações sobre suas atividades podem se identificar com eles. O foco conceitual não está na identificação com o partido em si, mas sim com republicanos ou democratas enquanto grupos sociais.

A escolha do eleitor por um candidato do partido X pode se dar por causa da identificação com o grupo partidário («militantes do partido $\mathrm{X}$ votam em candidatos de $\mathrm{X}$ ), mas também pode se dar por outros traços do candidato - raça, gênero, região, religião, classe social, etc. A explicação psicológica subjacente poderia ser desde a pura identificação com o grupo social do candidato (ex.: ceteris paribus, uma mulher prefere votar em outra mulher), até o estereótipo que o eleitor identifica com determinado grupo social (ex.: políticos negros têm mais propensão a defender minorias; eu defendo minorias; logo, votarei no candidato negro).

O desenvolvimento de estudos sobre a relação entre eleitores e grupos sociais se beneficiou de pesquisas oriundas da psicologia social e cognitiva. Uma abordagem teórica proveniente da área e que influenciou os estudos sobre escolha eleitoral e identidade partidária foi a teoria da identidade social (Tajfel 1982, 1981; Tajfel e Turner 1979) ${ }^{84}$. Segundo ela, a identidade social seria definida como

«that part of the individuals' self-concept which derives from their knowledge of their membership of a social group (or groups) together with the value and emotional significance of that membership» (Tajfel 1981, p. 255).

\footnotetext{
${ }^{83}$ Não ignoramos que as dificuldades informacionais enfrentadas pelos eleitores na hora do voto são altas em todas as democracias. Apenas ressaltamos o diagnóstico predominante na política comparada de que tais dificuldades são particularmente altas no caso brasileiro.

${ }^{84}$ Para uma revisão da literatura sobre identidade social e política, ver Huddy (2013).
} 
Nessa visão, a existência de grupos sociais supõem a consciência de pertencimento ao grupo, a associação do grupo a certos valores e, também, algum tipo de consenso «externo» sobre a existência do grupo (Tajfel 1982). Para Tajfel e Turner (1979), uma consequência da identidade social seria que a mera percepção de pertencimento a um grupo ativaria algum tipo de discriminação a favor do próprio grupo e/ou contra os outros grupos. A categorização em grupos sociais seria uma ferramenta cognitiva que segmenta e ordena o ambiente social, permitindo ao indivíduo agir e tomar uma série de decisões.

Em paralelo ao desenvolvimento da teoria da identidade social, a psicologia política e a ciência política buscaram entender os mecanismos pelos quais os cidadãos, a despeito de seu conhecimento limitado sobre questões políticas (cf. Converse 1964), poderiam agir politicamente. Um desses mecanismos seria o recurso heurístico. A consistência ou racionalidade por trás das decisões políticas dos eleitores, mesmo em eleições complexas e exigentes, poderia ser explicada por meio do processo heurístico, que permite aos indivíduos compensar sua informação limitada por meio de atalhos cognitivos. Segundo Sniderman, Brody e Tetlock,

«Heuristics are judgmental shortcuts, efficient ways to organize and simplify political choices, efficient in the double sense of requiring relatively little information to execute, yet yielding dependable answers even to complex problems of choice». (1991, p. 34)

Nessa visão, o processo heurístico funcionaria como uma espécie de atalho cognitivo, compensando (ao menos parcialmente) a falta de atenção e conhecimento dos indivíduos sobre a política. Desse modo, mesmo indivíduos pouco informados seriam capazes de fazer julgamentos políticos minimamente consistentes. Para Lau e Redlawsk (2001), esta visão se tornou tão forte na ciência política que já se poderia se referir a ela como a nova sabedoria convencional.

As características sociais dos candidatos podem ser usadas por meio do processo heurístico para que os eleitores infiram informações sobre suas posições políticas. Dado o caráter personalista das eleições em muitos países (Brasil e Estados Unidos, por exemplo), muito centradas nos candidatos, parece natural que as características deles atuem como «sinalizadores», para o eleitorado, de pertencimento a certos grupos.

A literatura recente que se debruçou sobre esse fenômeno encontrou evidências de que características dos candidatos têm impacto direto na escolha do eleitor. Características como gênero (Dolan 2014; McDermott 1997), raça (Aguilar et al. 2015; Carsey 2001, 1995; Citrin et al. 1990), além, é claro, da filiação partidária (Brader e Tucker 2011; Rahn 1993; Conover e 
Feldman 1989), podem atuar como pistas importantes para os eleitores, ainda que, em muitos casos, dependam da interação com outras variáveis.

A filiação religiosa não é exceção. A saliência da religião no debate político americano deu ensejo a experimentos focados no impacto da filiação religiosa sobre a escolha eleitoral. Esses estudos exploraram a relação entre pistas religiosas e estereótipos (McDermott 2009), partidos (Campbell et al. 2011), políticas públicas (Adkins et al. 2013) e apoio eleitoral (McLaughlin e Wise 2014). No caso do Brasil, até onde sabemos, Boas (2014) foi o único a realizar estudo experimental explorando a relação entre pistas religiosas e apoio eleitoral. As pesquisas mencionadas encontraram evidências consideráveis de que a filiação religiosa dos candidatos atua como atalho informacional para os eleitores. A influência da filiação religiosa pode variar, sendo nula ou negativa para certos grupos de eleitores. Porém, todos os estudos citados encontraram algum tipo de efeito significativo para o impacto da religião dos candidatos sobre o voto.

Não há consenso sobre quais grupos sociais teriam relevância política e eleitoral no Brasil. Para alguns pesquisadores, a sociedade brasileira teria clivagens de pouca saliência, sendo a clivagem social a única politicamente relevante (e.g., Reis 2010). É verdade que, do ponto de vista dos grupos religiosos, o Brasil foi, até a segunda metade do século XX, um país de grande maioria católica. Porém, nas últimas décadas, o país testemunhou um declínio acentuado do número de católicos, acompanhado por um crescimento de outros grupos, sobretudo protestantes (tradicionais e pentecostais). O Censo 2010 registrou um percentual de 22,2\% de protestantes na população brasileira. Segundo pesquisa amostral do Instituto Datafolha de dezembro de 2016, o percentual de evangélicos brasileiros já chegaria a $29 \%{ }^{85}$.

O crescimento do protestantismo no Brasil, bem como suas possíveis consequências, foi alvo de interesse acadêmico crescente a partir dos anos 1990 (e.g., Mariano e Pierucci 1992; Freston 1993; Pierucci e Prandi 1995; Fernandes 1998; Oro 2003; Borges 2009; Mariano e Oro 2011; Machado e Burity 2014). Grande parte desse interesse se voltou para os desdobramentos políticos do crescimento evangélico. Porém, com a já mencionada exceção de Boas (2014), nenhum estudo experimental buscou investigar o possível efeito que o uso de pistas religiosas por parte de candidatos evangélicos pode ter nas eleições legislativas brasileiras. Nosso trabalho busca contribuir nessa direção.

A partir da discussão acima, formulamos as seguintes hipóteses de pesquisa. Em primeiro lugar, acreditamos que eleitores evangélicos tendem a votar mais em candidatos evangélicos, e,

\footnotetext{
${ }^{85} \ll 44 \%$ dos evangélicos são ex-católicos», Datafolha, 28/12/16.
} 
inversamente, não-evangélicos votarão menos. Candidatos evangélicos que se valem de pistas religiosas - colocar o título de pastor em seu nome de urna, por exemplo - ganhariam votos de eleitores evangélicos, mas perderiam dos demais grupos. Em segundo lugar, queremos testar se o expressivo crescimento do número de evangélicos no Brasil não apenas aumentou a saliência dos evangélicos enquanto grupo social, mas também criou alguma saliência entre sub-grupos evangélicos. Acreditamos que eleitores reagirão de forma diferente a candidatos identificados genericamente como evangélicos e a candidatos vinculados a igrejas específicas. A literatura oferece subsídios para diferentes interpretações acerca da questão. Por um lado, muitos evangélicos pentecostais dão relativamente pouca ênfase a sua identificação com uma igreja específica, priorizando a identidade de evangélicos (cf. Lindhardt 2016). Nesse sentido, seria plausível supor que não há saliência relevante entre sub-grupos evangélicos. Por outro lado, o crescimento da população evangélica nas últimas décadas incentivou algumas igrejas a buscarem modos de organização e gestão empresariais, além de buscarem atuar na política de forma mais explícita e centralizada (cf. Mariano 2003; Oro 2003a). O exemplo mais ilustrativo é o da Igreja Universal. É plausível supor que igrejas pentecostais como a Universal se distinguam das outras não apenas dentro do grupo evangélico, senão também para outros grupos.

Por fim, tal qual encontrado em estudos pregressos, acreditamos que a oferta de candidatos pode ter um efeito interativo com a pista religiosa, (e.g. Aguilar et al. 2015; Cunow 2014). Ceteris paribus, quanto maior for o número de candidatos, maior efeito terá a pista religiosa para o eleitor. Isso faz sentido na medida em que o aumento do número de candidatos aumenta a dificuldade informacional e o custo cognitivo da escolha eleitoral, tornando mais importante a pista religiosa. Num ambiente com vários candidatos, eleitores se apoiarão mais em «atalhos» informacionais, tais como a pertença do candidato a grupos sociais e religiosos.

\section{Desenho do experimento}

De modo a testar nossas hipóteses, conduzimos um experimento de survey durante as eleições municipais brasileiras de 2016. A aplicação dos questionários começou no início de setembro, isto é, cerca de um mês antes do primeiro turno ( 2 de outubro), e se estendeu até o segundo turno (30 de outubro). Os questionários foram impressos e aplicados a uma amostra de conveniência de 730 estudantes de universidades privadas da cidade de São Paulo. As universidades escolhidas foram o Centro Universitário da Fundação Educacional Inaciana (FEI), a Universidade Paulista (UNIP) e a Universidade Ibirapuera (UNIB). Os estudantes respondentes eram provenientes de quatro cursos: Administração de Empresas (44\%); Engenharia (36.6\%); Direito (16.6\%); e Ciências da Computação (2.8\%). Com a exceção do último, esses cursos 
integram, há anos, a lista dos cursos de graduação com maior número de matrículas e ingressantes do Brasil, sendo Administração e Direito os primeiros da lista ${ }^{86}$. A escolha por instituições de ensino privadas se justifica pelo fato de elas concentrarem a grande maioria dos estudantes universitários brasileiros ${ }^{87}$. Ressaltamos que, em que pesem as considerações acima, a amostra utilizada neste estudo não é representativa da população brasileira, nem, a rigor, dos estudantes universitários brasileiros. No entanto, parece razoável supor que, se a relevância da identidade evangélica na escolha dos eleitores puder ser detectada a partir de uma amostra de estudantes universitários brasileiros (presumivelmente com maior renda e escolaridade do que a média dos brasileiros), então tal relevância provavelmente será tão ou mais forte no resto da população.

A tabela 10, abaixo, sintetiza as principais características da amostra. A idade média dos respondentes foi de 22,7 anos, e a mediana, de 21. A maior parte dos respondentes (56\%) era do sexo masculino. A proporção de estudantes do sexo feminino matriculados em cursos de graduação no Brasil em 2014 era de aproximadamente 55,7\%, o que significa que nossa amostra sub-representa as mulheres (cf. Censo da Educação Superior 2014). No que se refere à renda domiciliar, os respondentes estão relativamente distribuídos entre as cinco faixas, ainda que provavelmente haja uma sobre-representação na amostra de estudantes de maior renda vis-à-vis a população de estudantes.

\footnotetext{
86 Ver Censo da Educação Superior 2014. Informações disponíveis em: <http://portal.inep.gov.br/visualizar//asset_publisher/6AhJ/content/dados-apontam-aumento-do-numero-dematriculas?redirect=http://portal.inep.gov.br/> (acessado pela última vez em 5/01/17).

${ }^{87}$ Dos mais de três milhões de estudantes brasileiros que ingressaram em cursos de graduação em $2014,82 \%$ o fizeram em instituições privadas (Censo da Educação Superior 2014).
} 
Tabela 10. Descrição da amostra

\begin{tabular}{lc}
\hline \hline Idade & \\
\hline Média & 22,7 \\
Mediana & 21 \\
& \\
Sexo (em \%) & 44,0 \\
\hline Mulher & 56,0 \\
Homem & \\
& \\
Renda domicilar (em \%) & 12,1 \\
\hline Até dois mil reais & 26,0 \\
De dois a quatro mil & 23,4 \\
De quatro a seis mil & 12,1 \\
De seis a oito mil & 26,3 \\
Mais de oito mil & \\
& \\
Identificação partidária (em \%) \\
\hline Sim & 12,0 \\
Não & 88,0 \\
& \\
Raça (em \%) & 66,1 \\
\hline Branca & 7,1 \\
Preta & 21,3 \\
Parda & 0,7 \\
Indígena & 4,7 \\
Amarela &
\end{tabular}

Uma característica curiosa da amostra é o baixo grau de respondentes que manifestaram alguma identificação partidária. Sabe-se que os índices de identidade partidária são comparativamente baixos no Brasil. Segundo pesquisas do Datafolha feitas nos últimos anos e reportadas por Samuels e Zucco (2014), por volta de $40 \%$ a $45 \%$ do eleitorado brasileiro teria alguma identificação com partidos. É curioso, então, que apenas $12 \%$ de nossos respondentes tenham declarado ter algum partido político de preferência ou com o qual simpatiza. É plausível supor que a identidade partidária entre jovens seja menor, e que, portanto, não tenha havido significativa sub-representação em nossa amostra vis-à-vis a população brasileira de estudantes 
universitários $^{88}$. Por fim, a tabela 10 também apresenta a proporção das raças. A maior parte dos respondentes $(66,1 \%)$ se declarou branca. O segundo maior grupo foi o dos pardos, que chegou a $21,3 \%$, seguido dos negros, que chegaram a 7,1\%. Um percentual de 4,7\% se declarou amarelos e apenas $0,7 \%$ indígenas. Como se vê, a proporção de afro-brasileiros (pretos + pardos) não chega a 30\%, o que indica uma sub-representação em relação à população brasileira, ainda que, talvez, o percentual da amostra esteja próximo ao da população de estudantes universitários.

Os questionários também pediam aos respondentes que identificassem sua religião e sua frequência ao culto religioso. Como mostra a tabela 11, abaixo, a maior parte dos respondentes $(40,1 \%)$ se identificou como católico. O segundo maior grupo foi o dos «sem religião», com $21,6 \%$, seguido de perto pelos evangélicos, com 21,2\%. Cerca de 10,7\% dos respondentes se identificaram como espíritas, e 6,5\% se identificaram com outras religiões. A comparação desses percentuais com o Censo 2010 revela que nossa amostra sub-representa católicos e sobrerepresenta espíritas e indivíduos «sem religião». No entanto, as diferenças encontradas entre nossa amostra e a população brasileira provavelmente são semelhantes às encontradas entre esta última e a população de estudantes brasileiros.

\begin{tabular}{lc} 
Tabela 11. Religião da amostra (em \%) \\
\hline \hline Católica & 40.1 \\
Evangélica & 21.2 \\
Espírita & 10.7 \\
Sem religião & 21.6 \\
Outra & 6.5 \\
\hline \hline
\end{tabular}

A frequência ao culto religioso (ver tabela 12) encontrada na amostra vai ao encontro da literatura sobre pentecostalismo no Brasil (cf. Bohn 2004). É forte o contraste entre católicos e evangélicos. Enquanto, no primeiro grupo, mais de 57\% dos respondentes não frequentam ou o fazem poucas vezes ao ano, no segundo grupo esse percentual é de 14,6\%. Em contrapartida, enquanto $27 \%$ de católicos vão à missa uma ou mais vezes por semana, para evangélicos esse percentual chega a $74,2 \%$.

\footnotetext{
${ }^{88}$ Em experimento preliminar feito com estudantes por Samuels e Zucco (2014), os autores também reportam terem obtido em sua amostra de estudantes percentuais de identidade partidária menores do que os que conseguiram com uma amostra não limitada a estudantes.
} 
Tabela 12. Religião e frequência ao culto (em \%)

\begin{tabular}{lcccc}
\hline \hline & Católica & Evangélica & Espírita & Outra \\
\hline Nunca ou quase nunca & 28.8 & 8.6 & 27.6 & 28.9 \\
Uma ou duas vezes por ano & 28.4 & 6.0 & 34.2 & 15.6 \\
Uma vez por mês & 15.8 & 11.3 & 21.1 & 22.2 \\
Uma vez por semana & 23.9 & 44.4 & 17.1 & 22.2 \\
Mais de uma vez por semana & 3.2 & 29.8 & 0.0 & 11.1 \\
TOTAL & 100 & 100 & 100 & 100 \\
\hline \hline
\end{tabular}

Os questionários foram distribuídos aos estudantes em sala de aula e devolvidos respondidos ao pesquisador que os aplicou. Cada questionário possuía 12 questões, sendo que uma delas pedia ao respondente que escolhesse um candidato a vereador entre as opções oferecidas (o questionário se encontra no Apêndice C). Os candidatos eram todos fictícios e foram construídos com base em informações de vereadores e deputados brasileiros existentes ${ }^{89}$. Havia dois modelos de questionários, um com dois candidatos e outro com seis. No modelo de dois candidatos, trabalhamos com quatro condições de tratamento: a primeira era o controle e não continha nenhum tipo de pista religiosa; na segunda, a descrição do segundo candidato (Felipe Souza) continha a informação de que ele seria membro da igreja Assembleia de Deus; a terceira era igual à segunda, exceto pela igreja, que passou a ser a Igreja Universal do Reino de Deus; por fim, a quarta condição não especificava a igreja de Souza, mas o apresentava como pastor. A figura 16, abaixo, apresenta os modelos com dois e seis candidatos do grupo de controle. Os tratamentos estão entre colchetes e em itálico.

\footnotetext{
${ }^{89}$ As fotos são de candidatos brasileiros e colombianos.
} 
FIGURA 16. Candidatos apresentados aos respondentes (modelos com dois e seis candidatos)

\section{Modelo com dois candidatos}

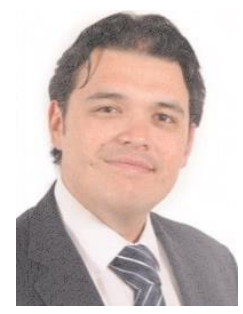

\section{CANDIDATO 1}

\section{Sérgio Pereira}

Sérgio nasceu em São Paulo, tem 43 anos e é formado em Direito. Após concluir a universidade, trabalhou em um escritório de advocacia, antes de decidir dedicar sua vida à política. Desde sua militância universitária, sempre atuou encabeçando projetos sociais que trouxessem benefícios para a sociedade. Ele é casado com Luciana e tem dois filhos: Renato, 12 anos, e Lilian, 9 anos.

\section{Propostas:}

- Aumentar os impostos sobre os mais ricos, a fim de aumentar os gastos sociais para aqueles mais necessitados.

- Criar programas de assessoria jurídica para a população mais carente.

- Permitir que as empresas privadas utilizem os recursos presentes nas Áreas de Proteção Ambiental da cidade, desde que apresentem um plano de recuperação aprovado pelo governo.

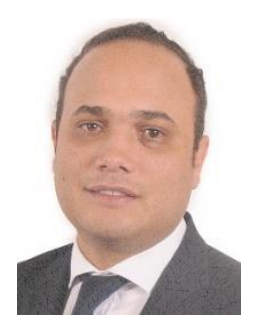

\section{CANDIDATO 2}

\section{[Pastor] Felipe Souza}

Felipe nasceu em São Paulo, tem 45 anos e é formado em Administração de Empresas. [É membro da Assembleia de Deus/ Igreja Universal do Reino de Deus.] Trabalhou como assessor na Câmara Municipal, ajudando a planejar o orçamento do município. Sua experiência de vida [como pastor] e preocupação pelas comunidades carentes paulistanas o credenciaram para, nestas eleições, concorrer ao cargo de Vereador. Felipe e sua esposa, Analice, têm dois filhos: Joana, 15 anos, e Fernanda, 11 anos.

\section{Propostas:}

- Melhorar a eficiência da gestão municipal por meio da avaliação e fiscalização dos funcionários públicos.

- Incentivar o empreendedorismo, sobretudo entre a população mais carente.

- Criar mais parques nas áreas mais afastadas do centro da capital. 


\section{Modelo com seis candidatos}

\section{CANDIDATO 1}

\section{Sérgio Pereira}

Sérgio nasceu em São Paulo, tem 43 anos e é formado em Direito. Após concluir a universidade, trabalhou em um escritório de advocacia, antes de decidir dedicar sua vida à política. Desde sua militância universitária, sempre atuou encabeçando projetos sociais que trouxessem benefícios para a sociedade. Ele é casado com Luciana e tem dois filhos: Renato, 12 anos, e Lilian, 9 anos.

Propostas:

- Aumentar os impostos sobre os mais ricos, a fim de aumentar os gastos sociais para aqueles mais necessitados.

- Criar programas de assessoria jurídica para a população mais carente.

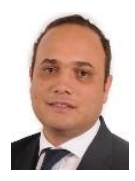

\section{CANDIDATO 2}

\section{[Pastor] Felipe Souza}

Felipe nasceu em São Paulo, tem 45 anos e é formado em Administração de Empresas. Trabalhou como assessor na Câmara Municipal, ajudando a planejar o orçamento do município. Sua experiência de vida [como pastor] e preocupação pelas comunidades carentes paulistanas o credenciaram para, nestas eleições, concorrer ao cargo de Vereador. Felipe e sua esposa, Analice, têm dois filhos: Joana, 15 anos, e Fernanda, 11 anos.

Propostas:

- Melhorar a eficiência da gestão municipal por meio da avaliação e fiscalização dos funcionários públicos.

- Incentivar o empreendedorismo, sobretudo entre a população mais carente.

\section{CANDIDATO 3}

\section{Pedro Oliveira}

Pedro tem 47 anos. É formado em Engenharia Civil e já atuou como consultor para órgãos municipais; devido a sua extensa experiência no setor público, optou por seguir carreira política, a fim de contribuir de forma mais efetiva para o desenvolvimento da cidade. É casado com Helena e não tem filhos.

Propostas:

- Criar um plano habitacional que tenha por finalidade inserir comunidades carentes em áreas centrais.

- Construir vias alternativas na cidade, visando contribuir para o escoamento do trânsito em ligações entre zonas.

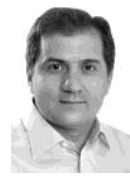

\section{CANDIDATO 4}

\section{Heitor Lima}

Heitor nasceu em São Paulo, tem 46 anos e é formado em Odontologia. Como médico, Heitor atuou por anos como voluntário, até fundar sua própria ONG, voltada para prevenção e cuidados bucais para comunidades carentes da Zona Sul de São Paulo. Ele e sua esposa Laura tem um filho, Yuri.

Propostas:

- Aumentar o número de postos de saúde com atendimento odontológico.

- Criar um programa para escolas municipais do ciclo básico, com ajuda das secretarias de saúde e educação, para promover noções básicas de cuidados pessoais, tais como higiene corporal e bucal, e nutrição.

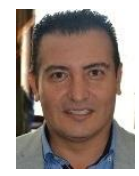

\section{CANDIDATO 5}

\section{Samuel Costa}

Samuel nasceu em São Paulo, tem 48 anos e é formado em Contabilidade. Samuel conta com mais de 10 anos de experiência como assessor na Assembleia Legislativa, sempre atuando na área de licitações do Estado. Tem particular interesse em questões trabalhistas. Samuel e sua esposa Catarina têm três filhos: Alice, Giovanna e Bruno.

Propostas:

- Instituir o Fórum Estadual de Prevenção e Erradicação do Trabalho Infantil - FEPETI - junto à Secretaria da Justiça e da Defesa da Cidadania. 
- Reservar no mínimo 5\% (cinco por cento) das vagas de emprego na área da construção civil de obras públicas no município para pessoas do sexo feminino.

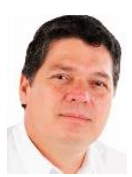

\section{CANDIDATO 6}

Artur Silva

Artur Silva tem 44 anos e é formado em Economia. Trabalhou como professor universitário e consultor para assuntos educacionais. Atualmente, é vereador, membro das comissões de Administração Pública e Educação, Cultura e Esportes. Artur é casado com Lucélia e tem uma filha, Ana Maria.

Propostas:

- Instituir o Programa de Educação para a Segurança no Trânsito nos Ensinos Fundamental e Médio da Rede Pública de Educação do município.

- Obrigar os pet shops, clínicas veterinárias e hospitais veterinários a informar a delegacia especializada em maus tratos aos animais, quando constatarem indícios de maus tratos nos animais por eles atendidos.

Tabela 13. Amostra segundo condições de tratamento.

\begin{tabular}{lcc}
\hline \hline & \multicolumn{2}{c}{ No. de candidatos } \\
\cline { 2 - 3 } & 2 & 6 \\
\hline Controle & 152 & 60 \\
Pista «Assembleia de Deus» & 156 & - \\
Pista «Igreja Universal» & 147 & - \\
Pista «Pastor» & 152 & 62 \\
\hline \hline
\end{tabular}

$\mathrm{O}$ modelo de seis candidatos continha apenas um tratamento, além do controle. $\mathrm{O}$ respondente deveria escolher um entre seis candidatos a vereador. Para o controle, nenhum dos candidato possuía pista religiosa. Para o tratamento, o candidato no. 2 (Felipe Souza) era apresentado como pastor. Os respondentes foram atribuídos aleatoriamente a uma das seis condições possíveis. Por fim, vale dizer que perguntamos aos respondentes se possuíam título de eleitor. Dos 730 respondentes, apenas dez afirmaram não ter.

\section{Resultados}

A figura 17, abaixo, apresenta a aleatorização e o balanço das variáveis entre os grupos de tratamento e controle. Apresentamos, para as seis variáveis relevantes, as médias e o intervalo de confiança de $95 \%$. De modo geral, há poucas diferenças. $\mathrm{O}$ conjunto das quatro primeiras condições apresenta uma pequena diferença em relação ao das duas últimas. No entanto, o mais importante é a semelhança das quatro primeiras entre si e das duas últimas entre si. Isso porque a 
primeira condição é o controle para a segunda, a terceira e a quarta, e a quinta condição é o controle para a sexta. Que a diferença seja um pouco maior entre as condições 1-4 e 5-6 não parece problemático. Podemos concluir, portanto, que a aleatorização foi bem-sucedida.

FIGURA 17. Aleatorização e balanço de variáveis entre grupos de tratamento
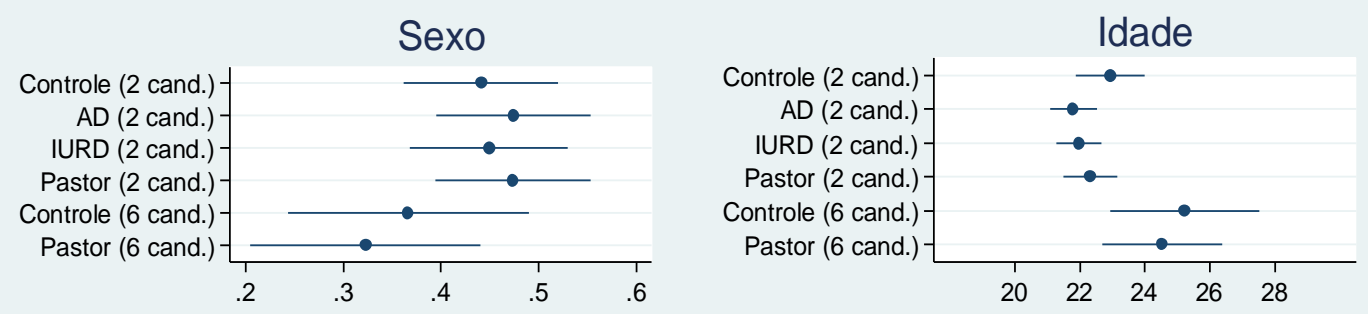

Ident. Partidária

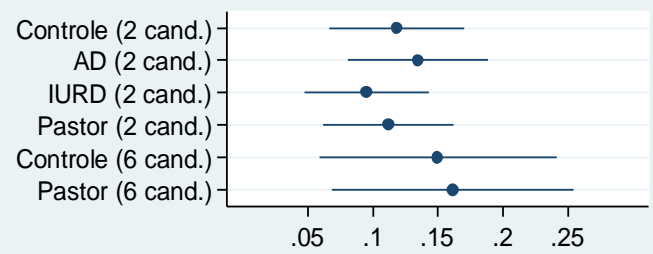

Renda
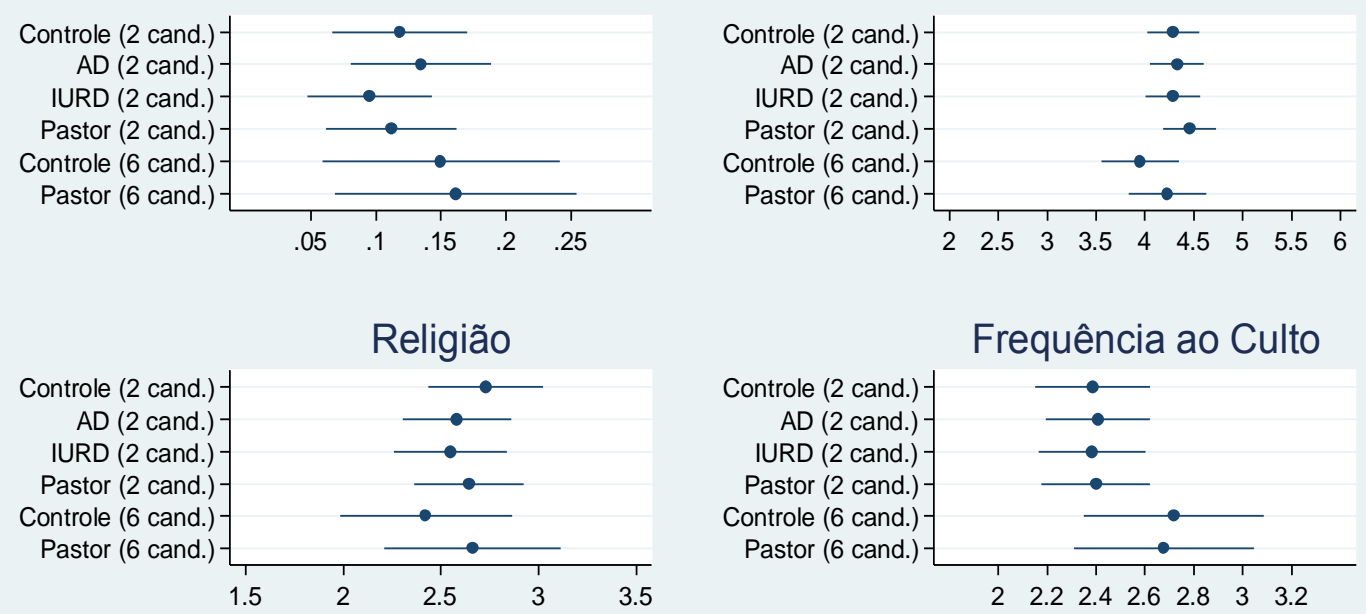

Frequência ao Culto

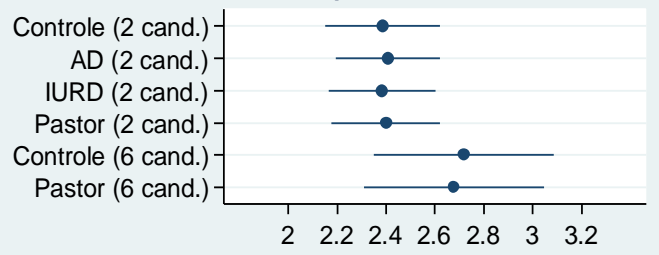

Os respondentes foram confrontados com a pergunta sobre o quão diferentes eram os candidatos apresentados em relação aos da última eleição. A tabela 14 mostra os resultados. Do total de 730 respondentes, mais de $54 \%$ consideraram os candidatos iguais ou apenas um pouco diferentes. Um percentual de $35 \%$ respondeu que os candidatos eram diferentes ou muito diferentes, e pouco mais de $10 \%$ não soube responder. Deve-se levar em conta que cada estudante recebeu um questionário e teve tempo para ler a descrição dos candidatos. Tal método de aplicação do questionário permite um escrutínio dos candidatos por parte do respondente maior do que quando a aplicação se dá com um pesquisador apenas mostrando o anexo para o respondente. Mesmo assim, os percentuais dos que consideraram os candidatos iguais ou um 
pouco diferentes nos dão segurança de que os perfis fictícios usados na pesquisa foram verossímeis e semelhantes aos candidatos reais ${ }^{90}$.

Tabela 14. Semelhança dos candidatos

\begin{tabular}{lc} 
Quão diferentes são esses candidatos em \\
relação aos da última eleição? (Em \%) \\
\hline Iguais & 20.3 \\
Um pouco diferentes & 33.9 \\
Diferentes & 24.8 \\
Muito diferentes & 10.2 \\
Não sei & 10.7 \\
Total & 100.0 \\
\hline
\end{tabular}

Vamos agora aos resultados principais. Como foi dito, nosso questionário confrontava o respondente com dois ou seis candidatos a vereador, dos quais ele deveria escolher um. Um dos candidatos (o segundo em ambos os modelos), Felipe Souza, aparecia com pistas religiosas para os respondentes dos grupos de tratamento, e sem nenhuma pista para aqueles dos grupos de controle. Sua descrição, portanto, era, exceto pelas pistas religiosas, idêntica em todos os grupos. Para apresentar os resultados, a escolha do candidato pelos respondentes foi codificada como uma variável binária, assumindo valor 1 para a escolha por Felipe Souza e 0 para qualquer outro candidato. Apresentamos os resultados de duas formas. Na primeira (tabela 15), mostramos a proporção de respondentes que escolheram Felipe Souza entre as diferentes condições de tratamento e entre os diferentes grupos religiosos. As proporções são acompanhadas de erros padrão e de intervalos de confiança de $95 \%$.

\footnotetext{
${ }^{90}$ É importante ressaltar essa constatação. Antes de nos decidirmos por aplicar questionários em estudantes universitários, fizemos um teste piloto aplicando os mesmos questionários em terminais de ônibus de São Paulo. A comparação entre as duas formas (aplicação no terminal versus aplicação na universidade) deixou claro que indivíduos abordados nas ruas ou em terminais tem uma propensão muito maior a responder que os candidatos são iguais aos da última eleição, mas uma propensão muito menor a prestar atenção no questionário.
} 
Tabela 15. Proporção de respondentes que escolheram Felipe Souza

\begin{tabular}{|c|c|c|c|c|}
\hline \multirow{3}{*}{$\begin{array}{l}\text { Condição } \\
\text { Controle ( } 2 \text { cand.) }\end{array}$} & \multicolumn{4}{|c|}{ Evangélicos } \\
\hline & \multirow{2}{*}{$\begin{array}{c}\text { Proporção } \\
0.778\end{array}$} & \multirow{2}{*}{$\begin{array}{c}\text { Erro Padrão } \\
0.082\end{array}$} & \multicolumn{2}{|c|}{ 95\% Intervalo de Conf } \\
\hline & & & 0.617 & 0.939 \\
\hline $\mathrm{AD}(2$ cand. $)$ & 0.724 & 0.084 & 0.557 & 0.891 \\
\hline IURD (2 cand.) & 0.538 & 0.100 & 0.341 & 0.736 \\
\hline Pastor (2 cand.) & 0.581 & 0.090 & 0.403 & 0.759 \\
\hline Controle (6 cand.) & 0.333 & 0.126 & 0.084 & 0.582 \\
\hline \multirow[t]{2}{*}{ Pastor (6 cand.) } & 0.474 & 0.118 & 0.241 & 0.706 \\
\hline & \multicolumn{4}{|c|}{ Católicos } \\
\hline Condição & Proporção & Erro Padrão & \multicolumn{2}{|c|}{ 95\% Intervalo de Conf. } \\
\hline Controle ( 2 cand.) & 0.673 & 0.064 & 0.547 & 0.798 \\
\hline $\mathrm{AD}$ ( 2 cand. $)$ & 0.594 & 0.062 & 0.472 & 0.716 \\
\hline IURD (2 cand.) & 0.517 & 0.065 & 0.389 & 0.645 \\
\hline Pastor ( 2 cand.) & 0.500 & 0.070 & 0.362 & 0.638 \\
\hline Controle (6 cand.) & 0.560 & 0.101 & 0.361 & 0.759 \\
\hline \multirow[t]{2}{*}{ Pastor (6 cand.) } & 0.200 & 0.092 & 0.019 & 0.381 \\
\hline & \multicolumn{4}{|c|}{ Sem religião } \\
\hline Condição & Proporção & Erro Padrão & $95 \%$ Inte & de Conf. \\
\hline Controle ( 2 cand.) & 0.622 & 0.081 & 0.462 & 0.781 \\
\hline $\mathrm{AD}(2$ cand. $)$ & 0.583 & 0.083 & 0.419 & 0.748 \\
\hline IURD (2 cand.) & 0.594 & 0.088 & 0.419 & 0.768 \\
\hline Pastor (2 cand.) & 0.500 & 0.100 & 0.302 & 0.698 \\
\hline Controle (6 cand.) & 0.222 & 0.147 & -0.068 & 0.513 \\
\hline \multirow[t]{2}{*}{ Pastor (6 cand.) } & 0.333 & 0.167 & 0.004 & 0.663 \\
\hline & \multicolumn{4}{|c|}{ Espiritas } \\
\hline Condição & Proporção & Erro Padrão & \multicolumn{2}{|c|}{ 95\% Intervalo de Conf. } \\
\hline Controle ( 2 cand.) & 0.733 & 0.118 & 0.498 & 0.969 \\
\hline $\mathrm{AD}(2$ cand. $)$ & 0.500 & 0.129 & 0.243 & 0.757 \\
\hline IURD (2 cand.) & 0.538 & 0.144 & 0.252 & 0.825 \\
\hline Pastor (2 cand.) & 0.667 & 0.105 & 0.457 & 0.877 \\
\hline Controle (6 cand.) & - & - & - & - \\
\hline Pastor (6 cand.) & 0.750 & 0.250 & 0.252 & 1.248 \\
\hline
\end{tabular}

Para todos os grupos religiosos, a inserção de uma pista religiosa, qualquer uma, diminuiu a escolha pelo candidato Felipe Souza no modelo de dois questionários. Esse resultado estava de acordo com nossa expectativa para o caso dos católicos, espíritas e sem religião, mas 
não estava para os evangélicos. No caso deles, há uma leve queda $(0,05)$ na escolha por Felipe Souza quando ele é apresentado como membro da Assembleia de Deus. Todavia, a queda é um pouco maior $(0,197)$ quando ele é apresentado como pastor e ainda maior $(0,24)$ quando é apresentado como membro da Igreja Universal. Para os demais grupos (católicos, sem religião e espíritas), a inclusão da pista religiosa diminui a escolha por Felipe Souza como previsto. A maior queda se dá entre católicos na comparação entre o controle e o tratamento de pastor (a diferença na proporção é de 0,173). Ainda assim, vale frisar que, com os tratamentos, a queda na escolha por Felipe Souza é em geral maior entre evangélicos do que entre os demais grupos.

Quanto ao modelo de seis candidatos, os resultados vão ao encontro do esperado. Ao serem confrontados com um maior leque de candidatos, e, portanto, com uma maior quantidade de informações, o atalho informacional religioso - a pista de «pastor» - se revela eficaz. Em outras palavras, os resultados estão de acordo com nossa conjectura de que a saturação de informações na escolha eleitoral inclina os respondentes a se apoiarem em atalhos cognitivos. O título de pastor é um desses atalhos. Embora, com apenas dois candidatos, os tratamentos tenham feito os evangélicos escolherem menos Felipe Souza, no cenário com seis candidatos o tratamento aumentou a proporção de votos para Souza em 0,141. Para católicos, o tratamento fez com que a proporção dos que escolheram Souza caísse 0,36, a maior queda entre todos os grupos registrados. Curiosamente, no modelo com seis candidatos, o grupo de controle dos «sem religião» escolheu mais Souza do que o grupo de tratamento. Com relação aos espíritas, o número de observações foi pequeno demais no modelo com seis candidatos para permitir qualquer comparação.

Em que pese a importância dos resultados apresentados acima, eles devem ser vistos com cautela. As proporções de todos os grupos de tratamento possuem intervalos de confiança que se sobrepõem em alguma medida aos dos grupos de controle. Mesmo se adotássemos intervalos de confiança de $90 \%$, as únicas proporções cujos intervalos não se sobreporiam seriam as dos católicos para o modelo de seis candidatos. Apenas nesse caso os intervalos de confiança dos grupos de controle e tratamento não estariam sobrepostos.

Para uma melhor análise dos dados, rodamos alguns modelos de regressões logísticas cujos resultados apresentamos abaixo. A variável dependente de todos os modelos é binária, assumindo valor 1 caso o respondente tenha escolhido Felipe Souza e 0 no caso de qualquer outro candidato. Todos os modelos possuem controles para sexo, idade, renda, raça, identidade partidária, seis candidatos e frequência ao culto. Com exceção de idade e renda, todas são dummies $^{91}$. Os coeficientes dos controles foram omitidos para simplificar a leitura, mas os modelos completos podem ser encontrados no Apêndice B.

\footnotetext{
${ }^{91}$ Todas as dummies possuem valor 1 ou 0 . Sexo assume valor 1 para mulheres; raça assume valor 1 para negros ou pardos; identidade partidária assume valor 1 para qualquer identidade; seis candidatos assume valor 1 para os
} 
A tabela 16, abaixo, apresenta os resultados dos modelos. O modelo 1 inclui dummies para os três tratamentos: AD, IURD e pastor. Todos os tratamentos apresentaram efeito negativo para a escolha do candidato Souza. Porém, apenas os tratamentos de «membro da IURD» e «pastor» apresentaram significância estatística (ambos ao nível 0.05). Cabe notar que o maior efeito negativo foi o de ser membro da IURD, seguido do de pastor.

Tabela 16. Regressões logísticas para voto no candidato Felipe Souza

\begin{tabular}{|c|c|c|c|c|c|}
\hline & Modelo 1 & Modelo 2 & Modelo 3 & Modelo 4 & Modelo 5 \\
\hline $\mathrm{AD}$ & $\begin{array}{c}-0.256 \\
(0.238)\end{array}$ & & & & \\
\hline IURD & $\begin{array}{c}-0.606 * * \\
(0.242)\end{array}$ & & & & \\
\hline Pastor & $\begin{array}{c}-0.452 * * \\
(0.213)\end{array}$ & & & & \\
\hline Congruência Evangélico & & $\begin{array}{l}0.324 \\
(.235)\end{array}$ & $\begin{array}{c}0.180 \\
(0.249)\end{array}$ & & \\
\hline Congru Evang * Seis Candidatos & & & $\begin{array}{c}1.036 \\
(0.667)\end{array}$ & & \\
\hline Congruência Católico & & & & $\begin{array}{c}-0.432 * * \\
(0.177)\end{array}$ & $\begin{array}{c}-0.351^{*} \\
(0.187)\end{array}$ \\
\hline Congru Cato $*$ Seis Candidatos & & & & & $\begin{array}{l}-0.826 \\
(0.638)\end{array}$ \\
\hline Constante & $\begin{array}{c}1.352 * * * \\
(0.463) \\
\end{array}$ & $\begin{array}{l}0.912 * \\
(0.466) \\
\end{array}$ & $\begin{array}{c}0.991 * * \\
(0.471)\end{array}$ & $\begin{array}{c}1.090 * * \\
(0.438)\end{array}$ & $\begin{array}{c}1.106 * * \\
(0.438) \\
\end{array}$ \\
\hline $\mathrm{N}$ & 693 & 636 & 636 & 693 & 693 \\
\hline Pseudo $\mathrm{R}^{2}$ & 0.0592 & 0.0343 & 0.0371 & 0.0572 & 0.0591 \\
\hline
\end{tabular}

Nota: erros padrão em parênteses. * para $\mathrm{p}<0.1 ; * *$ para $\mathrm{p}<0.05 ; * * *$ para $\mathrm{p}<0.01$.

Para o modelo 2, excluímos as dummies de tratamento e incluímos uma dummy que especifica se há congruência entre o respondente ser evangélico e o candidato Souza possuir alguma pista religiosa. Quando há, ou seja, quando o respondente é evangélico e recebeu tratamento, a variável assume valor 1 . O modelo 3 é igual, mas contém também uma interação entre a congruência descrita acima e o modelo de seis candidatos. Ou seja, a variável dummy de interesse no modelo 3 assume valor 1 se o respondente era evangélico, foi atribuído a um grupo 
de tratamento e ao modelo de seis candidatos. Os modelos 4 e 5 são iguais aos modelos 2 e 3 , exceto pelo fato de se referirem a católicos. No modelo 4, nossa dummy de interesse assume valor 1 se o respondente era católico e foi atribuído a um grupo de tratamento; no modelo 5, assume valor 1 se o respondente era católico, foi atribuído a grupo de tratamento e a questionário com seis candidatos.

Os modelos 2 e 3 revelam um efeito positivo para as pistas religiosas em respondentes evangélicos. Esse resultado chama a atenção por duas razões. Primeiro, porque, no caso do modelo 2 , contraria os resultados das proporções apresentadas na tabela 15 . O modelo 2 revela que, mantendo constantes os efeitos de sexo, idade, renda, raça e identidade partidária, a interação entre ser evangélico e ser atribuído a algum tratamento apresenta efeito positivo, mesmo no caso de questionários com apenas dois candidatos. Segundo, porque, no caso do modelo 3, a interação entre ser evangélico, ser atribuído ao tratamento e ao modelo de seis candidatos apresenta efeito bem mais forte do que o das demais variáveis apresentadas. No entanto, os coeficientes não são estatisticamente significativos.

Como era de se esperar, os modelos 4 e 5 revelam um efeito negativo para a interação entre ser católico e pista religiosa (modelo 4) e ser católico, pista religiosa e questionário com seis candidatos (modelo 5). O efeito mais forte é o da interação do modelo 5. No entanto, apenas a interação entre ser católico e pista religiosa apresentou significância estatística (nível 0.05). Isso significa que houve um efeito negativo e significativo na intenção de voto de católicos para o candidato Souza quando ele foi apresentado com pistas evangélicas.

\section{Discussão}

De modo geral, os resultados apresentados acima vão ao encontro de nossas conjecturas. Chama atenção o fato de que, em modelo com apenas dois candidatos, a pista religiosa do candidato Felipe Souza tenha diminuído sua escolha até mesmo entre evangélicos. No entanto, ao mantermos constantes os efeitos de sexo, idade, renda, raça e identidade partidária, o efeito de ser evangélico sobre a probabilidade de escolher o candidato Souza quando ele é evangélico se tornou positivo.

Considerando os respondentes como um todo, vimos que a pertença a qualquer uma das duas igrejas (AD ou IURD) e o título de pastor tiveram um efeito negativo sobre a escolha do candidato Souza. No entanto, ao nos focarmos especificamente nos evangélicos, vimos que a probabilidade de escolherem o candidato Souza aumenta quando ele é apresentado com pistas religiosas. Quando a oferta de candidatos aumenta, o efeito se torna ainda maior. A situação é similar, porém inversa no caso dos católicos. Sua probabilidade de escolha por Souza diminui quando ele é apresentado com pistas religiosas (i.e., evangélicas), e diminui ainda mais quando aumentamos a oferta de candidatos. A despeito das diferenças nos desenhos dos experimentos, 
tais resultados se aproximam daqueles encontrados por Boas (2014) no sentido de ressaltar uma associação positiva entre pista evangélica e identidade evangélica do eleitor, e uma associação negativa entre pista evangélica e identidade católica. Os resultados se aproximam também daqueles encontrados por Aguilar, Cunow, Desposato e Barone (2015) no que diz respeito à oferta de candidatos. Quanto maior o número de candidatos, mais os eleitores tendem a se apoiar em atalhos informacionais para tomar suas decisões. A ressalva que devemos fazer para nossos resultados é que, para muitos dos modelos de regressão logística (2, 3 e 5), não conseguimos coeficientes estatisticamente significativos, o que provavelmente se deve ao tamanho de nossa amostra.

Esses resultados indicam que o uso de pistas religiosas por parte de candidatos evangélicos envolve um trade-off: sinalizar a identidade evangélica garante mais votos entre os eleitores evangélicos, mas diminui seu apoio entre os demais eleitores. Dada o alto nível de competição das eleições brasileiras - marcadas por um alto número de candidatos, mas, também, por distritos de alta magnitude -, o trade-off parece valer a pena, ao menos para candidatos menos competitivos (cf. Capítulo 3). Garantir um percentual pequeno, porém seguro de votos pode ser uma boa estratégia.

Por fim, quanto à conjectura de que sub-grupos evangélicos teriam adquirido alguma saliência, os resultados apontam para uma diferença notável entre o efeito produzido pela pertença do candidato à $\mathrm{AD}$, à IURD ou o simples uso do título de pastor. Para católicos e evangélicos, a pertença à Igreja Universal diminuiu a escolha pelo candidato Souza em proporção muito maior do que os outros tratamentos. Já a pertença à $\mathrm{AD}$ e o título de pastor possuem menores diferenças entre si. 


\section{Capítulo 5}

\section{Considerações Finais}

O crescimento notável dos evangélicos no Brasil, bem como sua vitalidade e ativismo político, têm motivado um crescente número de estudos nas ciências sociais. Embora divirjam em escopo, método e área disciplinar, muitos desses estudos avaliaram a mobilização política dos evangélicos das últimas décadas como nociva à democracia brasileira. Tais análises, em geral, partiram de suposições teóricas e empíricas que não foram adequadamente fundamentadas. Nesta tese, esforcei-me por trazer tais suposições para o centro da investigação e do debate.

Algumas das maiores igrejas evangélicas brasileiras vem demonstrando, desde os anos 1980, uma notável vitalidade política. Essas igrejas não apenas abandonaram a postura de apoliticismo mantida durante boa parte do século XX, como optaram por uma forte atuação política e eleitoral. Nesse processo, algumas delas, tais como a Assembleia de Deus e a Igreja Universal, vem participando com êxito da dinâmica político-eleitoral brasileira. Tal participação se daria de duas formas básicas. A primeira seria a das eleições para os executivos municipais, estaduais e federal. $\mathrm{O}$ apoio dessas igrejas seria cada vez mais necessário para o sucesso de candidatos disputando prefeituras, governos estaduais e, até mesmo, a presidência da República. Nessa visão, receber o apoio dos líderes pentecostais implicaria em receber os votos de seus fiéis, devidamente controlados pelos líderes. Esse apoio, porém, exigiria contrapartidas que os candidatos deveriam cumprir no caso de serem eleitos. A segunda forma seria a das eleições para o legislativo - mais uma vez, municipal, estadual e federal. Nesse caso, candidatos seriam representantes «oficiais» de igrejas pentecostais, que receberiam o apoio delas para se elegerem como parlamentares. Uma vez eleitos, defenderiam os interesses das igreja, supostamente em detrimento dos interesses da «vontade geral».

Esta tese investiga a participação dos protestantes pentecostais nas eleições para o legislativo. No primeiro capítulo, busquei explicitar a literatura sobre pentecostalismo e política na América Latina, sobretudo aquela que endossa a visão «pessimista» sobre os efeitos do crescimento pentecostal para a democracia. Argumentei que, muito embora a literatura faça referências freqüentes ao comportamento clientelista dos políticos pentecostais, tais referências são mais fáceis de fazer do que de provar. Mesmo se assumirmos que as menções ao clientelismo equivalem a dizer que políticos pentecostais produzem mais projetos de leis paroquiais do que os outros, não há evidências de que a hipótese seja verdadeira. Se há algo no comportamento legislativo dos deputados pentecostais que os distingue dos demais, é necessário demonstrar o 
que é. Se a mobilização política pentecostal se baseia em práticas nocivas à democracia, é necessário demonstrar quais são elas.

No capítulo 2, investiguei o desempenho dos candidatos evangélicos e pentecostais para as eleições da Câmara dos Deputados e das Assembleias Legislativas. Embora o número de evangélicos eleitos venha crescendo, o número relativo de candidatos vem se mantendo estável desde 2002. Mesmo o crescimento do número de eleitos deve ser visto com cautela, na medida em que, a despeito do crescimento, os evangélicos ainda são sub-representados nos legislativos brasileiros. No entanto, a maior parte dos candidatos evangélicos bem-sucedidos nas eleições é proveniente de igrejas pentecostais que adotam algum tipo de candidatura «oficial». Tal apoio costuma ser questionado por seu caráter supostamente ilegal ou imoral. Como já foi mencionado, é proibido fazer propaganda política em igrejas no Brasil (Lei 9.504/97, Art. 37). A lei, porém, proíbe a propaganda política em bens de uso público, não sendo específica a igrejas. Sua redação é vaga, dando margem para discussão sobre como e até onde se aplicaria. Embora haja casos diversos de igrejas extrapolando os limites da lei, muitas igrejas agem nos limites da legalidade, apoiando candidatos de forma sutil ou implícita. Conquanto as discussões jurídica e normativa sobre a legitimidade da representação corporativa pentecostal sejam importantes, meu objetivo é ressaltar que, não fosse o apoio das igrejas a seus candidatos, a sub-representação dos evangélicos no legislativo seria ainda maior do que é. Não é possível desconsiderar tal fato na discussão mais ampla sobre a representação política dos evangélicos.

Se a estabilidade relativa das candidaturas evangélicas no Brasil e sua sub-representação no parlamento colocam em questão a suposição de uma «força» evangélica na política, uma análise das taxas de sucesso das igrejas pentecostais torna tal suposição ainda mais frágil. A Assembleia de Deus, a maior igreja pentecostal do Brasil, elegeu em 2014 pouco mais da metade dos seus candidatos. Em todas as demais eleições analisadas aqui, ela elegeu menos de 50\%. A Igreja do Evangelho Quadrangular, conhecida por suas incursões na política, tampouco conseguiu eleger mais do que $50 \%$ de seus candidatos. Mesmo a Igreja Universal do Reino de Deus, talvez a mais eficaz no que diz respeito à disputa eleitoral, nunca elegeu todos os seus candidatos, e, em 2006 e 2010, elegeu menos de 50\% deles.

O sucesso eleitoral das igrejas pentecostais é, pois, inferior ao que normalmente se assevera. Igrejas pentecostais elegendo menos da metade dos candidatos que apoiaram para as eleições ao legislativo não corroboram a imagem de líderes religiosos controlando «rebanhos» dóceis e submissos. Fiéis não se traduzem necessariamente em votos. Todavia, tal afirmação não é contraditória com uma outra, a saber, que, em termos estatísticos, o apoio de uma igreja pentecostal a um candidato lhe rende um efeito positivo sobre seu desempenho eleitoral. Como procurei mostrar no capítulo 3 , há um efeito de ser apoiado por uma igreja pentecostal sobre o voto. Tal efeito se mantém mesmo se mantemos constantes uma série de outros fatores, tais 
como o gasto de campanha, as preferências do distrito, o partido do candidato, entre outros. O apoio de uma igreja pentecostal, conquanto não garanta o sucesso, faz uma importante diferença para os votos do candidato, e fará ainda mais no caso de uma igreja centralizada e com forte estrutura, como é o caso da Universal.

No capítulo 4, apresentei evidências de que o uso de «pistas» religiosas por parte de candidatos evangélicos produz um efeito sobre eleitores evangélicos e católicos. No caso dos primeiros, o efeito é positivo; no caso do segundo, é negativo. Apenas o efeito negativo para católicos apresentou significância estatística. Cabe lembrar que tais efeitos crescem de modo considerável na medida em que a oferta de candidatos aumenta. $\mathrm{O}$ efeito num cenário com seis candidatos é maior do que num cenário com dois. Tal resultado vai ao encontro de outros estudos que investigaram o efeito de características de candidatos sobre os eleitores condicionando pela oferta de candidatos (cf. Aguilar et al. 2015; Cunow 2014). Nesse sentido, seria possível dizer que evangélicos não se comportam de maneira diferente da de outros grupos sociais, tais como mulheres e negros. À medida em que o custo cognitivo das eleições aumenta, eleitores (independente do grupo) tendem a se apoiar mais em «atalhos» informacionais.

Conforme dito na introdução, não acredito que as suposições normalmente usadas para julgar a participação política evangélica como deletéria à democracia sejam fundamentadas. Pelo contrário, argumentei que não há evidências de que o comportamento legislativo de políticos evangélicos seja significativamente distinto dos demais políticos. Argumentei, também, que a «força» eleitoral dos evangélicos é menor do que normalmente se supõe. A presente tese é, evidentemente, parte de um esforço coletivo mais amplo. Será apenas com novos estudos, de diferentes orientações e abordagens metodológicas, que poderemos fazer um juízo mais adequado sobre a mobilização de grupos religiosos na democracia brasileira.

É necessário distinguir aqueles que violam as obrigações de cidadania de uma democracia liberal daqueles que simplesmente defendem políticas das quais discordamos (cf. Weithman, 2002). É possível que muitos dos que se opõem às bandeiras políticas defendidas pelos evangélicos justifiquem sua oposição acusando os evangélicos de violarem as regras democráticas. Isso seria, obviamente, uma injustiça. Tentei, neste trabalho, afastar-me de juízos normativos e compreender como se dá a participação política dos evangélicos no Brasil atual. Essa compreensão pode oferecer subsídios para uma melhor avaliação do que representa a mobilização política evangélica, sua real dimensão, bem como seus limites. 


\section{REFERÊNCIAS BIBLIOGRÁFICAS}

ABRÚCIO, Fernando L. (1998). Os Barões da Federação: os Governadores e a Redemocratização Brasileira. Editora Hucitec.

ADKINS, Todd; LAYMAN, Geoffrey; CAMPBELL, David; GREEN, John (2013). «Religious Group Cues and Citizen Policy Attitudes in the United States». Politics and Religion, vol. 6, no. 2, pp. 235-263.

AGUILAR, Rosario; CUNOW, Saul; DESPOSATO, Scott; BARONE, Leonardo (2015). «Ballot Structure, Candidate Race, and Vote Choice in Brazil. Latin American Research Review, 50(3), 175-202.

AMES, Barry. (2001). The Deadlock of Democracy in Brazil: Interests, Identities, and Institutions in Comparative Politics. Ann Arbor; University of Michigan Press.

AVELINO, George (1994). «Clientelismo e Política no Brasil: Revisitando Velhos Problemas». Novos Estudos Cebrap, no. 38.

BASTIAN, Jean-Pierre (1994). Protestantismos y Modernidad Latinoamericana: Historia de unas Minorías Religiosas Activas en América Latina. México; Fondo de Cultura Económica.

BAPTISTA, Saulo (2007). Cultura Política Brasileira, Práticas Pentecostais e Neopentecostais: a Presença da Assembleia de Deus e da Igreja Universal do Reino de Deus no Congresso Nacional (1999-2006). Tese de doutorado. São Bernardo do Campo, Universidade Metodista.

BARBOSA, Caio M. (2015). «Os Fiéis da Universal na Eleição de 2014: um Estudo de Caso na Periferia de São Paulo». Trabalho apresentado no V Seminário Discente de Pós-Graduação em Ciência Política da USP, São Paulo.

BICA, Alessandro; TAMBARA, Elomar (2004). «O Ensino Religioso em Pelotas na Perspectiva do Jornal Estandarte Cristão (1925-1935)». Anais do X Encontro Sul-Rio-Grandense de Pesquisadores em História da Educação, Gramado, RS.

BOAS, Taylor (2013). «Serving God and Man: Evangelical Christianity and Electoral Politics in Latin America». Paper presented at the annual meeting of the APSA, Chicago, IL.

BOAS, Taylor (2014). «Pastor Paulo vs. Doctor Carlos: Professional Titles as Voting Heuristics in Brazil». Journal of Politics in Latin America, 6 (2), 39-72.

BOAS, Taylor; SMITH, Amy E. (2013). «Religion and the Latin American Voter». In: CARLIN, Ryan; SINGER, Matthew; ZECHMEISTER, Liz (eds.). The Latin American Voter (no prelo).

BOHN, Simone R. (2004). «Evangélicos no Brasil: perfil socioeconômico, afinidades ideológicas e determinantes do comportamento eleitoral». Opinião Pública, vol. 10, no. 2, pp. 288-338. 
BORGES, Tiago (2010). «Identidade Política Evangélica e os Deputados Estaduais Brasileiros». Perspectivas: Revista de Ciências Sociais, 35.

BORGES JR., Jerônimo (2010). A Participação Política da Igreja Evangélica Assembleia de Deus no Estado do Maranhão Pós-1986. Dissertação de Mestrado. Universidade Federal do Piauí, Teresina.

BRADER, Ted; TUCKER, Joshua (2011). «Follow the Leader: Party Cues, Policy Opinion, and the Power of Partisanship in Three Multiparty Systems». Working paper, Instituto Juan March de Estudios e Investigaciones, Madrid.

BUENO, Natália; DUNNING, Thad (2014). «Race, Resources, and Representation: Evidence from Brazilian Politicians». Available at SSRN: http://ssrn.com/abstract=2498662.

BURDICK, John (1998). Procurando Deus no Brasil: a Igreja Católica Progressista no Brasil na Arena das Religiões Urbanas Brasileiras. Rio de Janeiro, Editora Mauad.

CALVO, Ernesto; GUARNIERI, Fernando; LIMONGI, Fernando (2015). «Why Coalitions?

Party System Fragmentation, Small Party Bias, and Preferential Vote in Brasil». Electoral Studies, vol. 39, pp. 219-229.

CAMPBELL, Angus; CONVERSE, Phillip; MILLER, Warren; STOKES, Donald (1960). The American Voter. University of Chicago Press.

CAMPBELL, David; GREEN, John; LAYMAN, Geoffrey (2011). «The Party Faithfull: Partisan Images, Candidate Religion, and the Electoral Impact of Party Identification». American Journal of Political Science, vol. 55, no. 1, pp. 42-58.

CAMPOS, Leonildo (2005). «Os Políticos de Cristo: uma Análise do Comportamento Político de Protestantes Históricos e Pentecostais no Brasil». In: BURITY, Joanildo; MACHADO, Maria das Dores (orgs.). Os Votos de Deus: Evangélicos, Políticas e Eleições no Brasil. Recife, Fundação Joaquim Nabuco.

CARREIRÃO, Yan S. (2007). «Relevant Factors for the Voting Decision in the 2002 Presidential Election: An Analysis of the ESEB (Brazilian Electoral Study) Data». Brazilian Political Science Review, vol. 1, no. 1, pp. 70-101.

CARSEY, Thomas (1995). «The Contextual Effects of Race on White Voter Behavior: The 1989 New York City Mayoral Election». The Journal of Politics, 57(1), 221-228.

CARSEY, Thomas (2001). «Racial Context and Racial Voting in New York City Mayoral Elections Revisited». In annual meeting of the Southern Political Science Association, Atlanta, Georgia.

CARVAlHO, José Murilo de (1997). «Mandonismo, Coronelismo, Clientelismo: uma Discussão Conceitual». Dados, vol. 40, no. 2. 
CERVELlINI, Silvia; GIANI, Malu; PAVANELLI, Patrícia (2010). «Economia, Religião e Voto: a Questão do Aborto na Eleição Presidencial de 2010». IV Congresso Latino-Americano da WAPOR, Belo Horizonte.

CHESNUT, Andrew R. (1997). Born Again in Brazil: the Pentecostal Boom and the Pathogens of Poverty. New Jersey, Rutgers University Press.

CITRIN, Jack; GREEN, Donald; SEARS, David (1990). «White Reactions to Black Candidates: When Does Race Matter?». Public Opinion Quarterly, 54(1), 74-96.

CLARK, William; GILLIGAN, Michael; GOLDER, Matt (2006). «A Simple Multivariate Test for Asymmetric Hypotheses». Political Analysis, vol. 14, no. 3, pp. 311-31.

CONOVER, Pamela; FELDMAN, Stanley (1989). «Candidate Perception in an Ambiguous World: Campaign, Cues, and Inference Process». American Journal of Political Science, vol. 33, no. 4, 912-940.

CONVERSE, Philip (1964). «The Nature of Belief Systems in Mass Publics». Critical Review, vol. 18, nos. 1-3, pp. 1-74.

CUNOW, Saul (2014). Vote Choice in Complex Electoral Environments. Tese de Doutorado. Universidade da Califórnia, San Diego.

CUYABANO, Felippe O. (2009). A Política da Salvação: a Política e o Encantamento da Igreja Universal do Reino de Deus em Cáceres - MT. Dissertação de Mestrado. Pontifícia Universidade Católica de São Paulo, São Paulo.

DANCYGIER, Rafaela; LINDGREN, Karl-Oskar; OSKARSSON, Sven; VERNBY, Kare (2015). «Why Are Immigrants Underrepresented in Politics? Evidence from Sweden». American Political Science Review, vol. 109, no. 4, pp. 703-724.

D’EPINAY, Christian L. (1970). O Refúgio das Massas: Estudo Sociológico do Protestantismo Chileno. Tradução de Waldo Cesar. Rio de Janeiro; Ed. Paz e Terra.

DELLA CAVA, R. (1976). «Catholicism and society in twentieth-century Brazil». Latin American Research Review, 11 (2), 7-50.

DODSON, Michael (1997). «Pentecostals, Politics, and Public Space in Latin America». In: CLEARY, Edward; STEWART-GAMBINO, Hannah (eds.). Power, Politics, and Pentecostals. Boulder; Westview Press.

DOLAN, Kathleen (2014). «Gender Stereotypes, Candidate Evaluations, and Voting for Women Candidates: What Really Matters?». Political Research Quarterly, 67 (1), 96-107.

DURKHEIM, Émile (1999). Da Divisão do Trabalho Social. Trad. de Eduardo Brandão. São Paulo, Editora Martins Fontes.

FERNANDES, Rubem C. (1998). Novo Nascimento: Os Evangélicos em Casa, na Igreja e na Política. Rio de Janeiro, Mauad. 
FONSECA, Alexandre B. (2008). «Religion and Democracy in Brazil: A Study of the Leading Evangelical Politicians». In: FRESTON, Paul (ed.). Evangelical Christianity and Democracy in Latin America. New York, Oxford University Press.

FRESTON, Paul (1993). Protestantes e Política no Brasil: da Constituinte ao Impeachment. Campinas. Tese de doutorado, Universidade Estadual de Campinas.

FRESTON, Paul (1999). "'Neo-Pentecostalism’ in Brazil: Problems of Definition and the Struggle for Hegemony». Arch. de Sc. Soc. des Rel., ano 44, no. 105, pp 145-162.

FRESTON, Paul (2008). «Introduction: The Many Faces of Evangelical Politics in Latin America». In: (ed.). Evangelical Christianity and Democracy in Latin America. New York, Oxford University Press.

FIGUEIREDO NETTO, Gabriela; SPECK, Bruno (2015). «Eleições 2014: uma Análise Sobre o Financiamento de Campanha dos Candidatos Pastores». Trabalho apresentado no $39^{\circ}$ Encontro Anual da ANPOCS, pp. 1-27.

GASKILL, Newton (1997). «Rethinking Protestantism and Democratic Consolidation in Latin America». Sociology of Religion, vol. 58, no. 1, pp. 69-91.

GILL, Anthony (1994). «Rendering unto Caesar? Religious Competition and Catholic Political Strategy in Latin America, 1962-79». American Journal of Political Science, vol. 38, no. 2, pp. 403-425.

GILL, Anthony (2001). «Religion and Comparative Politics». Annual Review of Political Science, vol. 4, pp. 117-38.

GILL, Anthony (2002). «The Study of Liberation Theology: What Next?». Journal for the Scientific Study of Religion, vol. 41, no. 1, pp. 87-89.

GREEN, Donald P.; KRASNO, Jonathan S. (1988). «Salvation for the Spendthrift Incumbent: Reestimating the Effects of Campaign Spending in House Elections». American Journal of Political Science, vol. 32, no. 4, pp. 884-907.

HAGOPIAN, Frances (2009). «Parties and Voters in Emerging Democracies». In: BOIX, Carles; STOKES, Susan (eds.). The Oxford Handbook of Comparative Politics. Oxford, Oxford University Press.

HUDDY, Leonie (2013). «From Group Identity to Politial Cohesion and Commitment». In: ; SEARS, David; LEVY, Jack (eds.). The Oxford Handbook of Political Psychology. New York: Oxford University Press.

IRELAND, Rowan (1999). «Popular Religions and the Building of Democracy in Latin America: Saving the Tocquevillian Parallel». Journal of Interamerican Studies and World Affairs, vol. 41, no. 4, pp. 111-136.

JACOBSON, Gary C. (1978). «The Effects of Campaign Spending in Congressional Elections». American Political Science Review, vol. 72, pp. 469-491. 
JACOBSON, Gary C. (1985). «Money and Votes Reconsidered: Congressional Elections, 19721982». Public Choice, vol. 47, pp. 7-62.

JACOBSON, Gary C. (1990). «The Effects of Campaign Spending in House Elections: New Evidence for Old Arguments». American Journal of Political Science, vol. 34, no. 2, pp 334-62.

KINZO, Maria D. G. (1997). «Governabilidade, Estrutura Institucional e Processo Decisório no Brasil». Parcerias Estratégicas, vol. 1, no. 3, pp. 9-25.

KINZO, Maria D. G. (2005). «Os Partidos no Eleitorado: Percepções Públicas e Laços Partidários no Brasil». RBCS, vol. 20, no. 57, pp. 65-81.

KITSCHELT, Herbert (2000). «Linkages Between Citizens and Politicians in Democratic Polities». Comparative Political Studies, vol. 33, no. 6/7, pp. 845-879.

KITSCHELT, Herbert; WILKINSON, Steven (2007). «Citizen-politician linkages: an introduction». In: (eds.). Patrons, Clients, and Policies: Patterns of

Democratic Accountability and Political Competition. New York, Cambridge University Press.

LAU, Richard; REDLAWSK, David (2001). «Advantages and Disadvantages of Cognitive Heuristics in Political Decision Making». American Journal of Political Science, vol. 45, no. 4, pp. 951-971.

LEAL, Victor N. (1948). Coronelismo, Enxada e Voto: o Município e o Regime Representativo no Brasil. São Paulo; Editora Alfa-Omega.

LEMOS, Leany B.; MARCELINO, Daniel; PEDERIVA, João H. (2010). «Porque Dinheiro Importa: a Dinâmica das Contribuições Eleitorais para o Congresso Nacional em 2002 e 2006». Opinião Pública, vol. 16, no. 2, pp. 366-393.

LEONI, Eduardo; PEREIRA, Carlos; RENNÓ, Lúcio (2003). «Estratégias para Sobreviver Politicamente: Escolhas de Carreiras na Câmara dos Deputados do Brasil». Opinião Pública, vol. 9, no. 1, pp. 44-67.

LEVINE, Daniel (2009). «The Future of Christianity in Latin America». Journal of Latin American Studies, vol. 41, no. 1, pp. 121-145.

LIMA JR., Olavo B. (1999). «Reformas de Sistemas Eleitorais: Mudanças, contextos e consequências». Dados, vol. 42, no. 1, pp. 17-61.

LIMONGI, Fernando (2015). «O Passaporte de Cunha e o Impeachment». Novos Estudos Cebrap, vol. 103, pp. 99-115.

LINDHARDT, Martin (2016). «Time to Move On: Pentecostal Shifting and Religious Competition in Contemporary Chile». In: (ed.). New Ways of Being Pentecostal in Latin America. Lexington Books.

MACHADO, Maria das Dores (2005). «Evangélicos e as Eleições de 2002 no Rio de Janeiro: as Disputas pelo Poder Legislativo em Perspectiva». In: BURITY, Joanildo; (orgs.). 
Os Votos de Deus: Evangélicos, Políticas e Eleições no Brasil. Recife, Fundação Joaquim Nabuco.

MACHADO, Maria D. C. (2012). «Religião, Cultura e Política». Religião \& Sociedade, 32(2), pp. 29-56.

MACHADO, Maria D. C.; BURITY, Joanildo (2014). «A Ascensão Política dos Pentecostais no Brasil na Avaliação de Líderes Religiosos». Dados, vol. 57, no. 3, pp. 601-631.

MAINWARING, Scott (1999). Rethinking Party Systems in the Third Wave of Democratization: the Case of Brazil. Stanford University Press.

MAINWARING, Scott (2004). Igreja Católica e Política no Brasil (1916-1985). Trad. de Heloisa B. O. Prieto. São Paulo, Editora Brasiliense.

MANCUSO, Wagner P. (2015). «Investimento Eleitoral no Brasil: Balanço da Literatura (20012012) e Agenda de Pesquisa». Revista de Sociologia e Política, vol. 23, no. 54, pp. 155-183.

MANSBRIDGE, Jane (1999). «Should Blacks Represent Blacks and Women Represent Women? A Contingent 'yes'». The Journal of Politics, 61 (3), 628-657.

MARIANO, Ricardo (1999a). Neopentecostais: Sociologia do Novo Pentecostalismo no Brasil. São Paulo, Edições Loyola.

MARIANO, Ricardo (1999b). «O Futuro Não Será Protestante». Ciências Sociais e Religião, ano 1, no. 1, pp. 89-114.

MARIANO, Ricardo (2003). «Efeitos da Secularização do Estado, do Pluralismo e do Mercado Religiosos Sobre as Igrejas Pentecostais». Civitas, vol. 3, no. , pp. 111-125.

MARIANO, Ricardo (2004). «Expansão Pentecostal no Brasil: o Caso da Igreja Universal». Estudos Avançados, vol. 18, no. 52, pp. 121-138.

MARIANO, Ricardo; ORO, Ari P. (2011). «The Reciprocal Instrumentalization of Religion and Politics in Brazil». Annual Review of the Sociology of Religion, vol. 2, pp. 245-266.

MARIANO, Ricardo; PIERUCCI, Antônio (1992). «O Envolvimento dos Pentecostais na Eleição de Collor». Novos Estudos Cebrap, 34, 92-106.

MARIZ, Cecília (1992). «Religion and Poverty in Brazil: A Comparison of Catholic and Pentecostal Communities». Sociological Analysis, vol. 53, pp. 63-70.

MARIZ, Cecília (1994). Coping with Poverty: Pentecostals and Christian Base Communities in Brazil. Philadelphia; Temple University Press.

MARTIN, David (1990). Tongues of Fire: The Explosion of Protestantism in Latin America. Cambridge, Blackwell Publishers.

MARTIN, David (1999). «The Evangelical Upsurge and Its Political Implications». In: BERGER, Peter (ed.). The Desecularization of the World: Resurgent Religion and World Politics. Michigan, William B. Erdmans Publishing Company.

MAYHEW, David (1974). Congress: The Electoral Connection. Yale University Press. 
MCDERMOTT, Monika L. (1997). «Voting Cues in Low-information Elections: Candidate Gender as a Social Information Variable in Contemporary United States Elections». American Journal of Political Science, 270-283.

MCDERMOTT, Monika L. (2009). «Religious Stereotyping and Voter Support for Evangelical Candidates». Political Research Quarterly, vol. 62, no. 2, pp. 340-354.

MCLAUGHLIN, Bryan; WISE, David (2014). «Cueing God: Religious Cues and Voter Support». Politics and Religion, vol. 7, no. 2, pp. 1-29.

MIRANDA, Júlia (2006). «O Candidato da Igreja: do Que nos Fala a sua Presença na Política Brasileira». In: LEMENHE, M.; CARVALHO, R. (orgs.). Política, Cultura e Processos Eleitorais. Fortaleza, Fundação Konrad Adenauer.

NORRIS, Pippa; LOVENDUSKI, Joni (1995). Political Recruitment: Gender, Race and Class in the British Parliament. Cambridge: Cambridge University Press.

ORO, Ari P. (2003a). «A Política da Igreja Universal e seus Reflexos nos Campos Religioso e Político Brasileiros». RBCS, vol. 18, no. 53, pp 53-69.

ORO, Ari P. (2003b). «Organização Eclesial e Eficácia Política: o Caso da Igreja Universal do Reino de Deus». Civitas, vol. 3, no. 1, pp. 98-109.

PAIVA, Denise; TAROUCO, Gabriela (2011). «Voto e Identificação Partidária: os Partidos Brasileiros e a Preferência dos Eleitores». Opinião Pública, vol. 17, no. 2, pp. 426-451.

PEIXOTO, Vitor; RENNÓ, Lucio (2011). «Mobilidade Social Ascendente e Voto: as Eleições Presidenciais de 2010 no Brasil». Opinião Pública, vol. 17, no. 2, pp. 304-332.

PEREIRA, Carlos; RENNÓ, Lucio (2001). «O que É que o Reeleito Tem? Dinâmicas PolíticoInstitucionais Locais e Nacionais nas Eleições de 1998 para a Câmara dos Deputados». Dados, vol. 44 , no. 2 .

PEREIRA, Carlos; RENNÓ, Lúcio (2007). «O que É que o Reeleito Tem? O Retorno: o Esboço de uma Teoria da Reeleição no Brasil». Revista de Economia Política, vol. 27, no. 4, pp. 664-83. PERISSINOTTO, Renato; MIRÍADE, Angel (2009). «Caminhos para o Parlamento: Candidatos e Eleitos nas Eleições para Deputado Federal em 2006». Dados, vol. 52, no. 2, pp. 301-333.

PIERUCCI, Antônio (1989). «Representantes de Deus em Brasília: a Bancada Evangélica na Constituinte». Ciências Sociais Hoje, 11, 104-132.

PIERUCCI, Antônio; PRANDI, Reginaldo (1995). «Religiões e Voto: a Eleição Presidencial de 1994». Opinião Pública, v. 3, n. 1, p. 32-63.

PIERUCCI, Antônio (2011). «Eleição 2010: Desmoralização Eleitoral do Moralismo Religioso». Novos Estudos CEBRAP, no. 89, pp. 5-15.

PITKIN, Hanna (1967). The Concept of Representation. University of California Press. 
POWER, Timothy; ZUCCO, Cesar (2009). «Estimating Ideology of Brazilian Legislative Parties, 1990-2005: a Research Communication». Latin American Research Review, 44 (1), pp. 218-246.

RAHN, Wendy M. (1993). «The Role of Partisan Stereotypes in Information Processing about Political Candidates». American Journal of Political Science, pp. 472-496.

RICCI, Paolo (2000). «O Conteúdo da Produção Legislativa Brasileira: Leis Nacionais ou Políticas Paroquiais?». Dados, vol. 46, no. 4, pp. 699-734.

RODRIGUES, Guilherme Alberto; FUKS, Mario (2015). «Grupos Sociais e Preferência Política: o Voto Evangélico no Brasil». RBCS, vol. 30, no. 87, pp. 115-128.

ROLIM, Francisco C. (1980). Religião e Classes Populares. Petrópolis: Editora Vozes.

RUDI, Luciana M. (2006). Um Voto de Fé: Fidelização e Clientelismo Eleitoral na Bancada Evangélica Paulista. Dissertação de Mestrado. São Carlos, Universidade Federal de São Carlos.

SACCHET, Teresa; SPECK, Bruno (2012). «Financiamento Eleitoral, Representação Política e Gênero: uma Análise das Eleições de 2006». Opinião Pública, 18 (1), 177-197.

SAMUELS, David (2001a). «Incumbents and Challengers on a Level Playing Field: Assessing the Impact of Campaign Finance in Brazil». The Journal of Politics, vol. 63, no. 2, pp. 569-584. SAMUELS, David (2001b). «Money, Elections, and Democracy in Brazil». Latin American Politics and Society, vol. 43, no. 2, pp. 27-48.

SAMUELS, David; ZUCCO, Cesar (2014). «The Power of Partisanship in Brazil: Evidence from Survey Experiments». American Journal of Political Science, 58(1), 212-225.

SANTOS, Lívia (2013). «Confiança ou Cabresto? Considerações sobre o Comportamento Eleitoral de um Grupo Evangélico nas Eleições Municipais de 2012». Revista Intratextos, vol. 4, no. 1 .

SANTOS, F.; CANELlO, J. (2015). «Brazilian Congress, 2014 Elections and Governability Challenges». BPSR, vol. 9, no. 1 .

SCHOENFELDER, Rosilene; PAZ, Joice L. (2006). “A Igreja do Evangelho Quadrangular nas Eleições de 2006: a Disputa pela Vaga de Deputado Federal”. Debates do NER, ano 7, no. 10, pp. 27-37.

SMITH, Christian (1994). «The Spirit of Democracy: Base Communities, Protestantism, and Democratization in Latin America». Sociology of Religion, vol. 55, no. 2, pp. 119-143.

SNIDERMAN, Paul; BRODY, Richard; TETLOCK, Philip (1991). Reasoning and Choice: Explorations in Political Psychology. Cambridge University Press.

SOUZA, André R. (2009). «O Desempenho Político-Eleitoral dos Evangélicos de 1986 a 2008». Revista Brasileira de História das Religiões, vol. 1, no. 3. 
SPECK, Bruno; MANCUSO, Wagner (2014). «A Study on the Impact of Campaign Finance, Political Capital and Gender on Electoral Performance». Brazilian Political Science Review, vol. 8, no. 1, pp.34-57.

STARK, Rodney; SMITH, Buster (2012). «Pluralism and the Churching of Latin America». Latin American Politics and Society, vol. 54, no. 2, pp. 35-50.

STARK, Rodney; IANNACCONE, Laurence (1994). "A Supply-side Reinterpretation of the "Secularization" of Europe». Journal for the scientific study of religion, 230-252.

STOKES, Susan (2007). «Political Clientelism». In: BOIX, Carles; (eds.) The

Oxford Handbook of Comparative Politics. New York, Oxford University Press.

STOLL, David (1990). Is Latin America Turning Protestant?. Berkeley; University of California Press.

STRATMAN, Thomas (2005). «Some Talk: Money in Politics. A (Partial) Review of the Literature». Public Choice, no. 124, pp. 135-156.

TAJFEL, Henri (1981). Human Groups and Social Categories: Studies in Social Psychology. Cambridge University Press.

TAJFEL, Henri (1982). «Social Psychology of Intergroup Relations». Ann. Rev. Psychol., 33, pp. 1-39.

TAJFEL, Henri; TURNER, John (1979). «An Integrative Theory of Intergroup Conflict». The Social Psychology of Intergroup Relations, 33(47), 74.

TOMIO, Fabrício; RICCI, Paolo (2012). «O Governo Estadual na Experiência Política Brasileira». Revista de Sociologia e Política, vol. 21, no. 41, pp. 193-217.

VALLE, Vinicius S. M. (2013). Pentecostalismo e Lulismo na Periferia de São Paulo: Estudo de Caso sobre uma Assembleia de Deus na Eleição Municipal de 2012. Dissertação de Mestrado, Faculdade de Filosofia, Letras e Ciências Humanas, Universidade de São Paulo, São Paulo.

WÄNGNERUD, Lena (2009). «Women in Parliaments: Descriptive and Substantive Representation. Annual Review of Political Science, 12, 51-69.

WEBER, Max (2004). A Ética Protestante e o "Espirito" do Capitalismo. Trad. de José M. Macedo. São Paulo, Companhia das Letras.

WILLEMS, Emilio (1967). Followers of the New Faith: Culture Change and the Rise of Protestantism in Brazil and Chile. Nashville, Vanderbilt University Press.

YOUNG, Iris M. (2002). Inclusion and Democracy. Oxford University Press.

\section{OUTRAS REFERÊNCIAS}

CENSO DEMOGRÁFICO (2010). Características Gerais da População, Religião e Pessoas com Deficiência. Rio de Janeiro: Instituto Brasileiro de Geografia e Estatística (IBGE). 


\section{APÊNDICE A}

Modelos de regressão OLS para a Câmara dos Deputados.

\section{Variável Dependente}

\begin{tabular}{|c|c|c|c|c|c|c|}
\hline & \multirow{2}{*}{$\begin{array}{c}(\mathrm{Ln}) \\
\text { Gasto per } \\
\text { capita } \\
\text { Modelo } 1\end{array}$} & \multirow{2}{*}{$\begin{array}{l}\% \text { Gasto } \\
\text { Modelo } 2\end{array}$} & \multicolumn{4}{|c|}{$\%$ Voto } \\
\hline & & & Modelo 3 & Modelo 4 & Modelo 5 & Modelo 6 \\
\hline $\begin{array}{l}\text { (Ln) Gasto per } \\
\text { capita }\end{array}$ & & & $\begin{array}{c}0.348 * * * \\
(0.011)\end{array}$ & & $\begin{array}{c}0.345^{* * * *} \\
(0.010)\end{array}$ & \\
\hline$\%$ Gasto & & & & $\begin{array}{c}0.488 * * * \\
(0.010)\end{array}$ & & $\begin{array}{c}0.489 * * * \\
(0.010)\end{array}$ \\
\hline Incumbente & $\begin{array}{c}2.601 * * * \\
(0.110)\end{array}$ & $\begin{array}{c}2.341 * * * \\
(0.104)\end{array}$ & $\begin{array}{c}0.952 * * * \\
(0.071)\end{array}$ & $\begin{array}{c}0.718^{* * *} * \\
(0.061)\end{array}$ & $\begin{array}{c}0.944 * * * \\
(0.071)\end{array}$ & $\begin{array}{c}0.717 * * * \\
(0.060)\end{array}$ \\
\hline Ex-prefeito & $\begin{array}{c}1.401 * * * \\
(0.197)\end{array}$ & $\begin{array}{c}0.889 * * * \\
(0.187)\end{array}$ & $\begin{array}{c}0.567 * * * \\
(0.118)\end{array}$ & $\begin{array}{c}0.622 * * * \\
(0.101)\end{array}$ & $\begin{array}{c}0.567 * * * \\
(0.118)\end{array}$ & $\begin{array}{c}0.618 * * * \\
(0.101)\end{array}$ \\
\hline $\begin{array}{l}\% \text { Votos Partido } \\
2010\end{array}$ & $\begin{array}{c}0.029 * * * \\
(0.006)\end{array}$ & $\begin{array}{c}0.014 * * \\
(0.005)\end{array}$ & $\begin{array}{c}0.008 * * \\
(0.003)\end{array}$ & $\begin{array}{c}0.011 * * * \\
(0.003)\end{array}$ & $\begin{array}{l}0.006 * \\
(0.003)\end{array}$ & $\begin{array}{c}0.012 * * * \\
(0.003)\end{array}$ \\
\hline Pentecostal & $\begin{array}{c}0.909 * * * \\
(0.223)\end{array}$ & $\begin{array}{c}0.057 \\
(0.212)\end{array}$ & $\begin{array}{l}0.339 * \\
(0.201)\end{array}$ & $\begin{array}{c}0.682 * * * \\
(0.172)\end{array}$ & & \\
\hline Evangélico & & & $\begin{array}{l}-0.031 \\
(0.183)\end{array}$ & $\begin{array}{l}-0.075 \\
(0.157)\end{array}$ & & \\
\hline Título Religioso & & & $\begin{array}{c}0.030 \\
(0.208)\end{array}$ & $\begin{array}{c}0.086 \\
(0.178)\end{array}$ & $\begin{array}{c}0.016 \\
(0.171)\end{array}$ & $\begin{array}{c}0.053 \\
(0.147)\end{array}$ \\
\hline (Pentecostal - IURD) & & & & & $\begin{array}{c}0.330 * * \\
(0.153)\end{array}$ & $\begin{array}{c}0.603 * * * \\
(0.131)\end{array}$ \\
\hline IURD & & & & & $\begin{array}{l}0.502 * \\
(0.270)\end{array}$ & $\begin{array}{c}0.933 * * * \\
(0.231)\end{array}$ \\
\hline Coalizão Federal & $\begin{array}{c}0.866^{* * * *} \\
(0.084)\end{array}$ & $\begin{array}{c}0.381 * * * \\
(0.080)\end{array}$ & $\begin{array}{l}-0.068 \\
(0.051)\end{array}$ & $\begin{array}{c}0.046 \\
(0.043)\end{array}$ & & \\
\hline Mulher & $\begin{array}{c}-0.212 * * \\
(0.093)\end{array}$ & $\begin{array}{l}-0.071 \\
(0.089)\end{array}$ & $\begin{array}{l}-0.040 \\
(0.056)\end{array}$ & $\begin{array}{c}-0.078 * \\
(0.048)\end{array}$ & $\begin{array}{l}-0.042 \\
(0.056)\end{array}$ & $\begin{array}{c}-0.080 * \\
(0.048)\end{array}$ \\
\hline Afro & $\begin{array}{c}-0.336^{* * *} \\
(0.074)\end{array}$ & $\begin{array}{c}-0.212 * * * \\
(0.070)\end{array}$ & $\begin{array}{c}-0.003 \\
(0.044)\end{array}$ & $\begin{array}{l}-0.017 \\
(0.038)\end{array}$ & $\begin{array}{l}-0.004 \\
(0.044)\end{array}$ & $\begin{array}{l}-0.018 \\
(0.038)\end{array}$ \\
\hline Idade & $\begin{array}{c}0.011^{* * * *} \\
(0.003)\end{array}$ & $\begin{array}{l}-0.001 \\
(0.003)\end{array}$ & $\begin{array}{c}-0.010 * * * \\
(0.002)\end{array}$ & $\begin{array}{c}-0.006^{* * *} \\
(0.001)\end{array}$ & $\begin{array}{c}-0.010 * * * \\
(0.002)\end{array}$ & $\begin{array}{c}-0.006^{* * *} \\
(0.002)\end{array}$ \\
\hline PSC & $\begin{array}{c}0.231 \\
(0.221)\end{array}$ & $\begin{array}{c}0.164 \\
(0.210)\end{array}$ & $\begin{array}{c}0.002 \\
(0.131)\end{array}$ & $\begin{array}{c}0.004 \\
(0.112)\end{array}$ & $\begin{array}{c}0.014 \\
(0.130)\end{array}$ & $\begin{array}{l}-0.018 \\
(0.112)\end{array}$ \\
\hline PRB & $\begin{array}{c}-0.616^{* * *} \\
(0.218)\end{array}$ & $\begin{array}{c}-0.387^{*} \\
(0.421)\end{array}$ & $\begin{array}{l}0.239^{*} \\
(0.130)\end{array}$ & $\begin{array}{l}0.216^{*} \\
(0.111)\end{array}$ & & \\
\hline Constante & $\begin{array}{c}-5.987 * * * \\
(0.161) \\
\end{array}$ & $\begin{array}{c}0.421 * * * \\
(0.153)\end{array}$ & $\begin{array}{c}2.738^{* * * *} \\
(0.115) \\
\end{array}$ & $\begin{array}{c}0.447 * * * \\
(0.082) \\
\end{array}$ & $\begin{array}{c}2.722 * * * \\
(0.113) \\
\end{array}$ & $\begin{array}{c}0.463 * * * \\
(0.082) \\
\end{array}$ \\
\hline $\mathrm{N}$ & 3109 & 3110 & 3109 & 3110 & 3109 & 3110 \\
\hline $\mathrm{R}^{2}$ & 0.304 & 0.203 & 0.442 & 0.591 & 0.442 & 0.590 \\
\hline
\end{tabular}

Nota: erros padrão em parênteses. * for $\mathrm{p}<0.1 ; * *$ for $\mathrm{p}<0.05 ; * * *$ for $\mathrm{p}<0.01$. 
Modelos de regressão OLS para as Assembleias Legislativas.

\section{Variável Dependente}

$(\mathrm{Ln})$

Gasto per \% Gasto \% Voto

capita

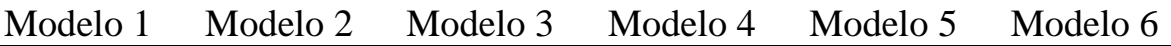

\begin{tabular}{|c|c|c|c|c|c|c|}
\hline (Ln) Gasto per capita & & & $\begin{array}{c}0.128 * * * \\
(0.002)\end{array}$ & & $\begin{array}{c}0.128 * * * \\
(0.002)\end{array}$ & \\
\hline$\%$ Gasto & & & & $\begin{array}{c}0.504 * * * \\
(0.006)\end{array}$ & & $\begin{array}{c}0.505 * * * \\
(0.006)\end{array}$ \\
\hline Incumbente & $\begin{array}{c}2.011 * * * \\
(0.070)\end{array}$ & $\begin{array}{c}0.871 * * * \\
(0.023)\end{array}$ & $\begin{array}{c}0.616 * * * \\
(0.016)\end{array}$ & $\begin{array}{c}0.434 * * * \\
(0.014)\end{array}$ & $\begin{array}{c}0.613 * * * \\
(0.016)\end{array}$ & $\begin{array}{c}0.431 * * * \\
(0.014)\end{array}$ \\
\hline Ex-prefeito & $\begin{array}{c}1.133 * * * \\
(0.111)\end{array}$ & $\begin{array}{c}0.358 * * * \\
(0.037)\end{array}$ & $\begin{array}{c}0.244 * * * \\
(0.024)\end{array}$ & $\begin{array}{c}0.209 * * * \\
(0.020)\end{array}$ & $\begin{array}{c}0.244 * * * \\
(0.024)\end{array}$ & $\begin{array}{c}0.209 * * * \\
(0.020)\end{array}$ \\
\hline $\begin{array}{l}\% \text { Votos Partido } \\
2010\end{array}$ & $\begin{array}{c}0.044 * * * \\
(0.004)\end{array}$ & $\begin{array}{c}0.011 * * * \\
(0.001)\end{array}$ & $\begin{array}{c}0.001 \\
(0.001)\end{array}$ & $\begin{array}{c}0.001 \\
(0.001)\end{array}$ & $\begin{array}{c}0.001 \\
(0.001)\end{array}$ & $\begin{array}{l}0.001 * \\
(0.001)\end{array}$ \\
\hline Pentecostal & $\begin{array}{c}0.597 * * * \\
(0.167)\end{array}$ & $\begin{array}{c}0.022 \\
(0.056)\end{array}$ & $\begin{array}{c}0.360 * * * \\
(0.050)\end{array}$ & $\begin{array}{c}0.383 * * * \\
(0.043)\end{array}$ & & \\
\hline Evangélico & & & $\begin{array}{c}-0.119 * * * \\
(0.046)\end{array}$ & $\begin{array}{l}-0.056 \\
(0.040)\end{array}$ & & \\
\hline Título Religioso & & & $\begin{array}{c}0.123 * * \\
(0.050)\end{array}$ & $\begin{array}{l}0.071 * \\
(0.050)\end{array}$ & $\begin{array}{c}0.032 \\
(0.036)\end{array}$ & $\begin{array}{l}0.025^{*} \\
(0.031)\end{array}$ \\
\hline (Pentecostal - IURD) & & & & & $\begin{array}{c}0.253 * * * \\
(0.042)\end{array}$ & $\begin{array}{c}0.311 * * * \\
(0.035)\end{array}$ \\
\hline IURD & & & & & $\begin{array}{c}0.416 * * * \\
(0.078)\end{array}$ & $\begin{array}{c}0.546 * * * \\
(0.067)\end{array}$ \\
\hline Coalizão Federal & $\begin{array}{c}0.419 * * * \\
(0.045)\end{array}$ & $\begin{array}{c}0.068 * * * \\
(0.015)\end{array}$ & $\begin{array}{c}0.001 \\
(0.010)\end{array}$ & $\begin{array}{c}0.021 * * \\
(0.008)\end{array}$ & & \\
\hline Mulher & $\begin{array}{l}-0.071 \\
(0.057)\end{array}$ & $\begin{array}{l}-0.021 \\
(0.019)\end{array}$ & $\begin{array}{c}-0.035^{* * *} \\
(0.012)\end{array}$ & $\begin{array}{c}-0.033 * * * \\
(0.010)\end{array}$ & $\begin{array}{c}-0.035 * * * \\
(0.012)\end{array}$ & $\begin{array}{c}-0.032 * * * \\
(0.010)\end{array}$ \\
\hline Afro & $\begin{array}{c}-0.146^{* * * *} \\
(0.041)\end{array}$ & $\begin{array}{c}-0.060 * * * \\
(0.013)\end{array}$ & $\begin{array}{l}-0.008 \\
(0.009)\end{array}$ & $\begin{array}{c}0.004 \\
(0.007)\end{array}$ & $\begin{array}{l}-0.008 \\
(0.009)\end{array}$ & $\begin{array}{c}0.004 \\
(0.007)\end{array}$ \\
\hline Idade & $\begin{array}{l}-0.002 \\
(0.002)\end{array}$ & $\begin{array}{c}-0.002 * * * \\
(0.001)\end{array}$ & $\begin{array}{c}-0.002 * * * \\
(0.000)\end{array}$ & $\begin{array}{c}-0.001 * * * \\
(0.000)\end{array}$ & $\begin{array}{c}-0.002 * * * \\
(0.000)\end{array}$ & $\begin{array}{c}-0.001 * * * \\
(0.000)\end{array}$ \\
\hline PSC & $\begin{array}{c}-0.209^{* *} \\
(0.105)\end{array}$ & $\begin{array}{l}-0.028 \\
(0.035)\end{array}$ & $\begin{array}{c}0.005 \\
(0.022)\end{array}$ & $\begin{array}{l}-0.006 \\
(0.019)\end{array}$ & $\begin{array}{c}0.005 \\
(0.022)\end{array}$ & $\begin{array}{l}-0.014 \\
(0.019)\end{array}$ \\
\hline PRB & $\begin{array}{l}-0.135 \\
(0.126)\end{array}$ & $\begin{array}{l}-0.056 \\
(0.043)\end{array}$ & $\begin{array}{c}0.054 * * \\
(0.027)\end{array}$ & $\begin{array}{c}0.066^{* * *} \\
(0.023)\end{array}$ & & \\
\hline Constante & $\begin{array}{c}-5.095 * * * \\
(0.097)\end{array}$ & $\begin{array}{c}0.315 * * * \\
(0.033)\end{array}$ & $\begin{array}{c}0.964 * * * \\
(0.024)\end{array}$ & $\begin{array}{c}0.150 * * * \\
(0.018)\end{array}$ & $\begin{array}{c}0.966 * * * \\
(0.024)\end{array}$ & $\begin{array}{c}0.158 * * * \\
(0.018)\end{array}$ \\
\hline $\mathrm{N}$ & 7295 & 7300 & 7295 & 7300 & 7295 & 7300 \\
\hline $\mathrm{R}^{2}$ & 0.191 & 0.215 & 0.502 & 0.638 & 0.501 & 0.637 \\
\hline
\end{tabular}

Nota: erros padrão em parênteses. $*$ for $\mathrm{p}<0.1 ; * *$ for $\mathrm{p}<0.05$; *** for $\mathrm{p}<0.01$. 


\section{APÊNDICE B}

Regressões logísticas para voto no candidato Felipe Souza (modelos completos)

\begin{tabular}{|c|c|c|c|c|c|}
\hline & Modelo 1 & Modelo 2 & Modelo 3 & Modelo 4 & Modelo 5 \\
\hline $\mathrm{AD}$ & $\begin{array}{l}-0.256 \\
(0.238)\end{array}$ & & & & \\
\hline IURD & $\begin{array}{c}-0.606^{* *} \\
(0.242)\end{array}$ & & & & \\
\hline Pastor & $\begin{array}{c}-0.452^{* *} \\
(0.213)\end{array}$ & & & & \\
\hline Congruência Evangélico & & $\begin{array}{l}0.324 \\
(.235)\end{array}$ & $\begin{array}{c}0.180 \\
(0.249)\end{array}$ & & \\
\hline Congru Evang * Seis Candidatos & & & $\begin{array}{c}1.036 \\
(0.667)\end{array}$ & & \\
\hline Congruência Católico & & & & $\begin{array}{c}-0.432 * * \\
(0.177)\end{array}$ & $\begin{array}{c}-0.351 * \\
(0.187)\end{array}$ \\
\hline Congru Cato * Seis Candidatos & & & & & $\begin{array}{l}-0.826 \\
(0.638)\end{array}$ \\
\hline Seis Candidatos & $\begin{array}{c}-0.946 * * * \\
(0.242)\end{array}$ & $\begin{array}{c}-0.943 * * * \\
(0.304)\end{array}$ & $\begin{array}{c}-1.255^{* * *} * \\
(0.375)\end{array}$ & $\begin{array}{c}-0.897 * * * \\
(0.227)\end{array}$ & $\begin{array}{c}-0.754 * * * \\
(0.250)\end{array}$ \\
\hline Mulher & $\begin{array}{c}-0.303 * \\
(0.165)\end{array}$ & $\begin{array}{c}-0.234^{*} \\
(0.169)\end{array}$ & $\begin{array}{l}-0.231 \\
(0.170)\end{array}$ & $\begin{array}{c}-0.275^{*} \\
(0.164)\end{array}$ & $\begin{array}{l}-0.271 \\
(0.165)\end{array}$ \\
\hline Idade & $\begin{array}{c}-0.048 * * * \\
(0.016)\end{array}$ & $\begin{array}{c}-0.034^{*} \\
(0.018)\end{array}$ & $\begin{array}{c}-0.037 * * \\
(0.018)\end{array}$ & $\begin{array}{c}-0.047 * * * \\
(0.016)\end{array}$ & $\begin{array}{c}-0.049 * * * \\
(0.016)\end{array}$ \\
\hline Renda & $\begin{array}{c}0.114 * * \\
(0.051)\end{array}$ & $\begin{array}{c}0.082 \\
(0.052)\end{array}$ & $\begin{array}{c}0.083 \\
(0.052)\end{array}$ & $\begin{array}{c}0.120 * * \\
(0.051)\end{array}$ & $\begin{array}{c}0.118 * * \\
(0.051)\end{array}$ \\
\hline Afro & $\begin{array}{l}-0.019 \\
(0.188)\end{array}$ & $\begin{array}{c}0.095 \\
(0.193)\end{array}$ & $\begin{array}{c}0.085 \\
(0.193)\end{array}$ & $\begin{array}{c}0.028 \\
(0.187)\end{array}$ & $\begin{array}{c}0.011 \\
(0.187)\end{array}$ \\
\hline Partido & $\begin{array}{c}-0.684 * * * \\
(0.248)\end{array}$ & $\begin{array}{c}-0.687 * * * \\
(0.258)\end{array}$ & $\begin{array}{c}-0.692 * * * \\
(0.260)\end{array}$ & $\begin{array}{c}-0.665 * * * \\
(0.246)\end{array}$ & $\begin{array}{c}-0.678 * * * \\
(0.247)\end{array}$ \\
\hline Praticante & $\begin{array}{c}0.419 * * \\
(0.169)\end{array}$ & & & $\begin{array}{c}0.423 * * \\
(0.169)\end{array}$ & $\begin{array}{c}0.420 * * \\
(0.169)\end{array}$ \\
\hline Constante & $\begin{array}{c}1.352 * * * \\
(0.463)\end{array}$ & $\begin{array}{l}0.912 * \\
(0.466)\end{array}$ & $\begin{array}{c}0.991 * * \\
(0.471)\end{array}$ & $\begin{array}{l}1.090 * * \\
(0.438)\end{array}$ & $\begin{array}{l}1.106 * * \\
(0.438)\end{array}$ \\
\hline $\mathrm{N}$ & 693 & 636 & 636 & 693 & 693 \\
\hline Pseudo $\mathrm{R}^{2}$ & 0.0592 & 0.0343 & 0.0371 & 0.0572 & 0.0591 \\
\hline
\end{tabular}

Nota: erros padrão em parênteses. $*$ para $\mathrm{p}<0.1 ; * *$ para $\mathrm{p}<0.05 ; * * *$ para $\mathrm{p}<0.01$. 


\section{APÊNDICE C (QUESTIONÁRIO)}

\section{Questionário $\mathrm{n}^{\mathrm{o}}$ :}

Olá! Estamos fazendo uma pesquisa para a USP/FGV sobre as preferências políticas dos eleitores brasileiros. Você poderia nos ajudar respondendo a algumas perguntas? Levará de 5 a 6 minutos.

Você tem título de eleitor?

( ) SIM

( ) NÃO

\section{TERMO DE CONSENTIMENTO - POR FAVOR, LEIA}

Antes de começar, gostaria de informar duas coisas: primeiro, que as suas respostas não serão identificadas, elas vão ser somadas com as das outras pessoas que estamos entrevistando; segundo, que nenhuma pergunta tem resposta certa ou errada, o que vale é a sua opinião, o que você pensa sobre o assunto. O mais importante, então, é que você seja sincero/a. Você aceita participar desta pesquisa?

1. Sexo:

( ) Masculino; $\quad$ ( ) Feminino.

2. Idade:

3. Você tem em geral algum partido político de preferência ou com o qual simpatiza?
( ) Sim:
( ) Não.

4. Qual a renda familiar mensal do seu domicílio, incluindo a renda de todos os adultos e filhos que trabalham?

( ) Até $\mathrm{R} \$ 1.000,00$ (até 1 salário mínimo);

( ) De $\mathrm{R} \$ 1.001,00$ a $\mathrm{R} \$ 2.000,00$ (de 1 a 2 salários mínimos);

( ) De $\mathrm{R} \$ 2.001,00$ a $\mathrm{R} \$ 4.000,00$ (de 2 a 4 salários mínimos);

( ) De $\mathrm{R} \$ 4.001,00$ a $\mathrm{R} \$ 6.000,00$ (de 4 a 6 salários mínimos);

( ) De $\mathrm{R} \$ 6.001,00$ a $\mathrm{R} \$ 8.000,00$ (de 6 a 8 salários mínimos);

( ) De $\mathrm{R} \$ 8.001,00$ a $\mathrm{R} \$ 10.000,00$ (de 8 a 10 salários mínimos);

( ) Mais de $\mathrm{R} \$ 10.000,00$ (mais de 10 salários mínimos); 
5. Agora, vou lhe apresentar o perfil de seis candidatos a vereador. Em qual desses candidatos você votaria? [VEJA O ANEXO NA FOLHA SEGUINTE.]
( ) Candidato 1 (Sérgio Pereira);
( ) Candidato 4 (Heitor Lima);
( ) Candidato 2 (Felipe Souza); ( ) Candidato 5 (Samuel Costa);
( ) Candidato 3 (Pedro Oliveira);
( ) Candidato 6 (Artur Silva);

6. Quão diferentes são esses candidatos em relação aos perfis que você viu na última eleição?
( ) Iguais;
( ) Um pouco diferentes;
( ) Diferentes;
( ) Muito diferentes.
( ) Não sei.

7. Você sabe quem é o atual Prefeito da cidade de São Paulo?

( ) Sim: ; ( ) Não.

8. Qual é sua religião?
( ) Católica;
( ) Evangélica (IGREJA: );
( ) Espírita;
( ) Umbanda;
( ) Sem religião/Ateu/Agnóstico;
( ) Outra:

9. Com que frequência você vai ao culto religioso?
( ) Nunca ou quase nunca;
( ) Uma ou duas vezes ao ano;
( ) Uma vez por mês;
( ) Uma vez por semana;
( ) Mais de uma vez por semana;

10. A igreja/culto que você frequenta...
( ) É perto da minha casa e vou a pé;
( ) É longe da minha casa, mas ainda assim vou a pé;
( ) É longe da minha casa e tenho que pegar pelo menos 1 condução, seja carro, ônibus, trem ou metrô.
( ) Não frequento.

11. Você se considera uma pessoa branca, preta, parda, indígena ou amarela?
( ) Branca;
( ) Preta (Afro-brasileira);
( ) Parda;
( ) Indígena;
( ) Amarela. 